University of Louisville ThinkIR: The University of Louisville's Institutional Repository

Electronic Theses and Dissertations

$12-2015$

\title{
Conflicted tourism : heritage narratives, sectarian schism, and economic growth in Northern Ireland.
}

Ashleigh Larissa Bixby

University of Louisville

Follow this and additional works at: https://ir.library.louisville.edu/etd

Part of the Social and Cultural Anthropology Commons

\section{Recommended Citation}

Bixby, Ashleigh Larissa, "Conflicted tourism : heritage narratives, sectarian schism, and economic growth in Northern Ireland." (2015). Electronic Theses and Dissertations. Paper 2300.

https://doi.org/10.18297/etd/2300

This Master's Thesis is brought to you for free and open access by ThinkIR: The University of Louisville's Institutional Repository. It has been accepted for inclusion in Electronic Theses and Dissertations by an authorized administrator of ThinkIR: The University of Louisville's Institutional Repository. This title appears here courtesy of the author, who has retained all other copyrights. For more information, please contact thinkir@louisville.edu. 


\title{
CONFLICTED TOURISM:
}

HERITAGE NARRATIVES, SECTARIAN SCHISM, AND ECONOMIC GROWTH IN NORTHERN IRELAND

\section{By}

Ashleigh Larissa Bixby

B.A., University of Tennessee 2010

M.A., University of Louisville 2015

\author{
A Thesis \\ Submitted to the Faculty of the \\ In Partial Fulfillment of the Requirements \\ For the Degree of

\section{Master of Arts} \\ In Anthropology \\ Department of Anthropology \\ University of Louisville \\ Louisville, Kentucky
} College of Arts and Sciences of the University of Louisville

December 2015 
Copyright 2015 by Ashleigh Larissa Bixby

All rights reserved 

CONFLICTED TOURISM:

HERITAGE NARRATIVES, SECTARIAN SCHISM, AND ECONOMIC GROWTH IN NORTHERN IRELAND

By

Ashleigh Larissa Bixby

B.A. University of Tennessee, 2010

M.A., Univeristy of Louisville, 2015

A Thesis Approved on

4 December 2015

By the following Thesis Committee:

\begin{tabular}{c} 
Dr Shawn Parkhurst \\
Thesis Director \\
Second Committee Member \\
\hline $\begin{array}{c}\text { Dr Margath Walker } \\
\text { Third Committee Member }\end{array}$
\end{tabular}




\section{DEDICATION}

This thesis is dedicated to my grandparents

Mr Charles J Schroering Jr

and

Mrs Carolyn Hall Schroering

who have given me the opportunity to further my education. 
TABLE OF CONTENTS

ACKNOWLEDGEMENTS vi vi

ABSTRACT vii

LIST OF TABLES $\quad$ ix

LIST OF FIGURES $\quad \mathrm{x}$

INTRODUCTION 1

CHAPTER 1: THE DEVELOPMENT OF SOCIOPOLITICAL CONFLICT IN NORTHERN IRELAND 4

SOCIAL SCHISMS IN NORTHERN IRELAND

NATIONALISM AND UNIONISM

NARRATIVES OF IDENTITY

SPACE AND PLACE: A NORTHERN IRISH INTERPRETATION 13

THE CIVIL RightS MOVEMENT AND THE TROUBLES: 1969-1993 16

NORTHERN IRELAND RIOTS 1969

OPERATION BANNER, POLITICS, AND INTERNMENT

BLOODY SUNDAY (1972) 22

OPERATION MOTORMAN 23

THE SUNNINGDALE AGREEMENT 1973

CONSTITUTIONAL CONVENTION: 1975

PRISON PROTESTS

THE ANGLO-IRISH AGREEMENT 1985

CONTINUED UNREST: 1986-1996

THE GOOD FRIDAY AGREEMENT

THE PEACE PROCESS: 1999-2015 33

CHAPTER 2: HISTORY OF TOURISM ON THE ISLAND OF IRELAND

TOURISM AND THE ISLAND 36

TOURISM GROWTH: 1840-1914 37

NORTHERN IRISH TOURISM: 1880-1980 40

RESURGENCE: 1990-2001 44

REBRANDING NORTHERN IRELAND: 2004-2007 46

SIGNATURE PROJECTS

IMPLEMENTATION AND FURTHER DEVELOPMENT: 2007 AND BEYOND 53

CHAPTER 3: ANALYSIS OF NORTHERN IRISH CONFLICT SITES 
$\begin{array}{lr}\text { BELFAST } & 69\end{array}$

MURAL PAINTING IN NORTHERN IRELAND

OFFICIALIZING APPROPRIATION: MURALS AND MEMORIALS

OFFICIAL PRODUCTION: THE ULSTER MUSEUM AND TITANIC BELFAST 87

LOCALIZING APPROPRIATION: PEACE LINES 98

DERRY/LONDONDERRY 103

OFFICIAL PRODUCTION: THE MUSEUM OF FREE DERRY AND THE PEACE BRIDGE

LOCALIZING APPROPRIATION: THE DERRY BOGSIDE 107

\begin{tabular}{lr} 
CONCLUSION & 119 \\
\hline
\end{tabular}

REFERENCES 124

\section{APPENDIX}

APPENDIX A: HERITAGE SITE TABLE $\quad 129$

APPENDIX B: HERITAGE SITE MAP $\quad 152$

APPENDIX C: MAPS $\quad 155$

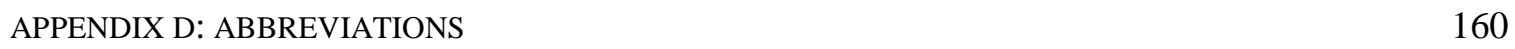

\begin{tabular}{lr} 
CURRICULUM VITAE & 162 \\
\hline
\end{tabular} 


\section{ACKNOWLEDGMENTS}

I would like to thank my advisor, Dr. Shawn Parkhurst for his guidance and imparting me with his wealth of knowledge along my journey. I would also like to thank the other committee members, Dr. Julie Peteet and Dr. Margath Walker, for their time, comments and assistance. I would like to thank my wife, Liz, for her constant support in my educational journey. Her patience has been invaluable as I filled our walls with post-it outlines and presented multiple drafts for her perusal. Also, thanks to my parents, Dan and Michelle Schroering, and my sister, Heather, for their support and encouragement to follow my own path in life, no matter how winding it may be. Finally, I would like to thank Sean Raleigh and Kristen Thomas-McGill for their invaluable input. I appreciate the time and effort given by everyone who supported me in my educational journey. 


\begin{abstract}
CONFLICTED TOURISM:

HERITAGE NARRATIVES, SECTARIAN SCHISM, AND ECONOMIC GROWTH IN NORTHERN IRELAND
\end{abstract}

\author{
A. Larissa Bixby
}

December 4, 2015

This thesis examines tourism as a politically charged facet of the economic process in Northern Ireland. While violence has abated in the region, sectarian conflict continues to affect Northern Irish society. Tourism has helped develop the economy by opening the market to visitors through the marketing of the region as unique and different. As conflict in the region is ongoing, the rise of tourism as a viable economic strategy raises the question: how does the Northern Irish tourist industry reconcile the past and ongoing conflict in order to present the region as a desirable tourist destination? The answer lies in the creation and appropriation of conflict sites. Conflict sites involve heritage. By focusing on these types of tourist attractions, attention is brought to the hidden - and continual - process of historical (re)formulation. The analytical categories of local-folk and official are instrumental in examining this process. They capture differing perspectives. The local-folk and official perspectives are not completely distinct. Instead they are intertwined and influence one another. They also vary across time and space. The concept of conflict tourism helps generate and address specific 
questions about such variation. How did the tourism industry develop within the socioeconomic and political spheres? How has it affected these spheres? Most specifically, why and how have sites connected with the events of the Troubles been appropriated and reimagined as tourist spaces? Answering such questions requires attention to the sociopolitical framework of the Northern Irish economy, the creation and marketing of the tourism industry, the impact conflict has upon tourist activities, and the impact tourism has upon conflict. 


\section{LIST OF TABLES}

TABLE 1: NITB GOALS FOR 2005-2007

TABLE 2: DETI GOALS FOR 2020

TABLE 3: CREATION OF HERITAGE SITES 


\section{LIST OF FIGURES}

FIGURE 1: THE SECTARIAN DIVIDE

FIGURE 2: THE CREATION OF THE INTERFACE/SANCTUARY 14

FIGURE 3: MAP OF IRELAND $\quad 18$

FIGURE 4: DETAIL OF NORTHERN IRELAND $\quad 18$

FIGURE 5: TITANIC BELFAST $\quad 61$

FIGURE 6: DETAIL OF WALLED CITY IN DERRY/LONDONDERRY 64

FIGURE 7: MAP OF DERRY/LONDONDERRY $\quad 64$

FIGURE 8: UNION COLORED KERB PAINTING $\quad 70$

FIGURE 9: KING WILLIAM OF ORANGE MURAL ON SHANKILL PARADE 71

FIGURE 10: CUCHULIANN ON THE LOWER SHANKILL ROAD

FIGURE 11: NATIONALIST CUCHULIANN MURAL NEAR DRUMARG PARK

FIGURE 12: RED HAND OF ULSTER IN THE LOWER SHANKILL 76

FIGURE 13: UNION FLAG

FIGURE 14: ST PATRICK'S SALTIRE

FIGURE 15: PROVINCIAL FLAG OF ULSTER

FIGURE 16: ULSTER BANNER

FIGURE 17: 'SNIPER' MURAL ON LOWER SHANKILL ROAD 79

FIGURE 18: MCCULLOUGH MURAL AS SEEN FROM DENMARK STREET

FIGURE 19: MCCULLOUGH MURAL FRONT VIEW

FIGURE 20: BOBBY SANDS MURAL ON SIDE OF SINN FÉIN HEADQUARTERS

FIGURE 21: MAGHABERRY GAOL FLYER

FIGURE 22: BOMBAY STREET MEMORIAL GATE

FIGURE 23: BOMBAY STREET MEMORIAL PLAQUE

FIGURE 24: BOMBAY STREET MEMORIAL MURAL $\quad 86$

FIGURE 25: ULSTER MUSEUM TROUBLES ROOM

FIGURE 26: TROUBLES ROOM ENTRANCE $\quad 88$

FIGURE 27: TROUBLES ROOM EXHIBIT IMAGE

FIGURE 28: TROUBLES ROOM EXHIBIT IMAGE

FIGURE 29: TROUBLES ROOM TROUBLES TIMELINE 90

FIGURE 30 : TROUBLES ROOM QUIET SPACE

FIGURE 31: HARLAND \& WOLFF GATE 95

FIGURE 32: TITANIC BOXER-SHORTS

FIGURE 33: TUBTANIC $\quad 97$

FIGURE 34: PEACE LINES BETWEEN FALLS \& SHANKILL NEIGHBORHOODS 99

FIGURE 35: CLOSE-UP OF PEACE LINE MESSAGES $\quad 100$

FIGURE 36: PEACE GATE $\quad 101$

FIGURE 37: PEACE MURAL $\quad 101$

FIGURE 38: PEACE MONUMENT $\quad 102$

FIGURE 39: DERRY/LONDONDERRY PEACE BRIDGE 106

FIGURE 40: FREE DERRY GABLE 108

FIGURE 41: MAZE PRISON/LONG KESH H BLOCKS MEMORIAL $\quad 109$

FIGURE 42: GUIDE TO FREE DERRY 
FIGURE 43: BRITISH MILITARY MAN MURAL

FIGURE 44: BERNADETTE DEVLIN BLOODY SUNDAY PROTEST MURAL 111

FIGURE 45: JACKIE DUDDY BLOODY SUNDAY MURAL 112

FIGURE 46: THE PETROL BOMBER $\quad 113$

FIGURE 47: THE SATURDAY MATINEE: THE RIOTER 114

FIGURE 48: BRADLEY BULLETIN 116

FIGURE 49: GRAFFITI ON THE WALLED CITY (2013) 117

FIGURE 50: GRAFFITI ON THE WALLED CITY (2009) 117 


\section{INTRODUCTION}

There is a contradiction between conflict and tourism. Tourism cannot thrive in a violence riddled region (Alluri 2009: 7), nor even, it is thought, in a fractious region. These regions are viewed as too dangerous by the average tourist. The regions are portrayed as desolate social and urban landscapes that have been devastated by sociopolitical conflict. Sectarian conflict has affected daily life in Northern Ireland since the colonization of the island. Sectarian conflict is a process that includes cycles of violence

and peace. In Northern Ireland, a period of peacebuilding began in 1998 after 30 years of violent unrest, called the Troubles. Tourism became a part of the ensuing economic expansion.

My preoccupation with analyzing tourism as an economic tool grew out of my interest in Northern Ireland's political murals. I knew as early as 2009 that some of the more famous political murals, for example Bobby Sands on Sevastopol Street in Belfast, were stops on bus tours. As I delved further into researching the murals, I became aware of other tours that took visitors to view less famous murals and their connection to the Northern Irish conflict. My focus shifted away from murals as art and public expression and towards the seemingly contradictory relationship between the sectarian struggle and tourism in Northern Ireland. The shift led directly to the problem of this thesis: the relationship between conflict and tourism in Northern Ireland. The case study may illuminate relations between conflict and tourism elsewhere. 
Since 1998, violence in the region has been reduced significantly. While violence may abate, conflict may continue. Conflict is a struggle over power, sometimes violent, sometimes non-violent, between opposing - sometimes shifting - forces. It involves competition over resources, territory and the representation of history. In the case of Northern Ireland, a number of such factors have been at play. While part of the struggle in the past, economy plays a role in Northern Ireland's peacebuilding process today.

Tourism has helped develop the Northern Irish economy by opening the market to visitors. The region is marketed as unique, new, and different from the 'average' holiday experience offered by staple destinations such as London, Paris, or the Mediterranean coast. This turn in marketing raises the question: how does the Northern Irish tourist industry reconcile the past and ongoing conflict in order to present the region as a desirable tourist destination?

"Dark tourism" seems to answer the above question. The term "refers to visiting sites associated with death, suffering and tragedy", encompassing a wide range of sites from those associated with war, massacre, natural disasters, violent death, etc (Farmaki 2013: 281). Some of the sites I examine can be usefully labeled "dark sites". Others cannot. For this reason, I use the concept of conflict site. But what does this entail? Because conflict so often involves struggle over history, conflict sites can be categorized as heritage sites. By registering how conflict sites involve heritage, I call attention to this hidden - and continual - process of historical (re)formulation. To analyze this process, I developed the analytical categories of local-folk and official. I use the categories to understand narratives presented to the public. They capture differing 
perspectives. The local-folk and official perspectives are not completely distinct. Instead they are intertwined and influence one another. They also vary across time and space.

The concept of conflict tourism helps generate and address specific questions about such variation. How did the tourism industry develop within the socio-economic and political spheres? How has it affected these spheres? Most specifically, why and how have sites connected with the events of the Troubles been appropriated and reimagined as tourist spaces? Answering such questions requires attention to the sociopolitical framework of the Northern Irish economy, the creation and marketing of the tourism industry, the impact conflict has upon tourist activities, and the impact tourism has upon conflict.

The thesis is structured to answer these questions. Chapter 1 examines the Irish political economy. In doing so it pays particular attention to sociopolitical struggle and concepts of identity and space dating from the colonization of Ireland. Chapter 2 focuses on tourism's development in its socio-political context. Because sites vary, Chapter 3 offers an analysis of a number of conflict sites within the cities of Belfast and Derry/Londonderry. Overall, this thesis will examine tourism as a politically charged facet of the economic process. 


\section{CHAPTER 1}

\section{THE DEVELOPMENT OF SOCIOPOLITICAL CONFLICT IN NORTHERN IRELAND}

Because tourism and conflict operate among changes in Northern Ireland's sociopolitical and economic structures, this chapter examines continuities and shifts within those structures. In order, this chapter examines social schism in Northern Ireland, different kinds of narratives accounting for that schism, the role of spatial difference in the schism, and its narratives within the historical confines of the conflict.

\section{$\underline{\text { Social Schisms in Northern Ireland }}$}

A schism in its most general definition is a split within a social group. This split can take place among various lines of disagreement; including religious, political and economic. In Northern Ireland, socio-religious schisms created two distinct political categories. These have influenced political and economic agendas.

\section{Nationalism and Unionism}

Conflict over sovereignty has been a part of everyday life since the midseventeenth century in Northern Ireland. There was little ethnic difference between the native peoples of Ireland and their colonizers. Instead, it was religion that "drew the line" between native peoples, the ruling elite, and the colonizers (James 1999: 127). The 
religious divide was worsened in the late seventeenth century during the Glorious Revolution and the successive civil war for the British Crown.

In 1690, former King James II/VII attempted to overthrow William III of Orange. The two monarchs met at the Battle of the Boyne, where William defeated James. Sovereignty of England, Scotland and Ireland was at stake. William, a Protestant, repealed the Catholic attempt to regain power in England by defeating Catholic King James at the Battle of the Boyne (Rolston 1991: 15). This battle is said to justify Protestant dominance in Ireland. In spite of this, Protestant factions were not always united.

Two Protestant factions became the majority in Ireland - the Anglican gentry and the non-conformist middle class. In 1690, Non-conformists allied themselves with William III in the hopes of gaining political recognition (Rolston 1991: 15-16). Yet, after the war, ruling power remained in the hands of the Anglican gentry. In 1798, Nonconformists joined with the Catholic lower class in the United Irishmen revolution. While the revolution was quashed by the British backed Anglicans, the Act of Union 1801 that followed "gave the middle class the niche it sought"; stronger economic ties with England (Rolston 1991: 16-17).

From 1801 onwards, two distinct political categories were formed - Irish Nationalists and British Unionists. These categories formed along the religious and class divide, which developed out of the cultural division of labor. The cultural division of labor is tied to class. Industrialization came late to Ireland. The island continued to remain economically dependent upon Britain after its shift from agrarian based economy to industrialization. Class groups emerged along religious lines, Irish Catholics constitute 
the majority of the working class, they are also more likely to support an autonomous Ireland. Scottish and English descendent Protestants form the majority of the middle and upper classes, they are more likely to support British unionism (Hechter 1975: 39-40) ${ }^{1}$.

Unionism and Nationalism are all encompassing categories for many groups and factions that operate in the name of one ideology or the other. They include subcategories: Republican and Loyalist. Generally, nationalists identify as Irish and support a united Ireland. A republican is a nationalist who completely rejects the Northern Irish government and British rule. They advocate for the removal of British governance through direct action and violence if necessary. The term 'republican' usually references paramilitary organizations or groups whose cause is furthered through violent action. The Real Irish Republican Army (RIRA) and the Provisional Irish Republican Army (PIRA) are examples of republican organizations. The term 'nationalist' is associated with political groups, like Sinn Féin, and citizens who support the idea of a united Ireland.

Unionists identify as British and support continued association with Great Britain. The term 'unionist' is used in relation to political parties such as the Democratic Unionist Party (DUP). A loyalist is a unionist who uses violent action to support the British claim to Northern Ireland. They believe that the eradication of Irish nationalists is a duty in protecting Britain's claim. The term 'loyalist' often refers to paramilitary organizations, for example, the Ulster Volunteer Force (UVF) and Ulster Defence Association (UDA). Figure 1 demonstrates the differences between the terms nationalist/republican and

\footnotetext{
${ }^{1}$ An in-depth analysis of the cultural division of labor on the British Isles can be found in Michael Hechter's study Internal Colonialism (1975).
} 
unionist/loyalist and shows how a duality of narratives is created from the sectarian divide.

\begin{tabular}{|l|l|l|}
\hline & Cause related to Politics & Cause related to Violence \\
\hline $\begin{array}{l}\text { Supports unity with } \\
\text { Republic of Ireland }\end{array}$ & Nationalist & Republican \\
\hline Supports British claim & Unionist & Loyalist \\
\hline
\end{tabular}

Figure 1: The Sectarian Divide

\section{Narratives of Identity}

As a consequence of the domination of the British-identifying elite over the Irish working class, "an ethnic/religious division of labor, and residential segregation" began to form and was later "enforced by populist sectarian violence" (Feldman 2000: 52). The resentment held by "ethnic" Irish helped spark the Easter Uprising in 1916². In 1921, after previous failures, Irish nationalists staged a successful campaign for an Irish Free State. However, for the rest of the island to gain independence, six counties of Ulster ${ }^{3}$, would remain a part of the United Kingdom ${ }^{4}$. Despite this, the partitioning of the island did not silence the question of sovereignty. Internationally, British rule is recognized as the legitimate form of governance in Northern Ireland. On the ground, however, sovereignty is unsettled. Sovereignty is an issue addressed by what I call official and local-folk narratives. Officially and in unionist local-folk narratives, British rule is recognized. However, within nationalist local-folk narratives, British rule is contested and in some cases outright opposed.

\footnotetext{
${ }^{2}$ An unsuccessful attempt at rebellion in Dublin that resulted in the execution of many nationalist leaders, after Home Rule, the right to independent rule, failed to pass Parliament.

${ }^{3}$ Ulster is a region made up of nine counties in Ireland. Six of the nine counties make up Northern Ireland. Ulster has become a mainly unionist term to describe Northern Ireland, despite the region being a part of both the Republic of Ireland and the United Kingdom.

${ }^{4}$ See A History of Northern Ireland by Thomas Hennessey for an expanded account of the Easter Rising of 1916 and the secession o the Irish Free State.
} 
The official perspective is promoted by a governing elite and presented as the formal account of a society's traditions, history and culture. The local-folk perspective, on the other hand, is the everyday, lived experiences, morals and traditions of the people. The local-folk perspective lacks clear class definitions like Hall's popular or Scott's little traditions. Stuart Hall examines distinctions drawn between official and popular cultures, or the cultures of the dominant class verses that of "the working poor, the labouring classes and the poor" (Hall in Samuel 1981: 227). James C Scott also draws distinctions between the ruling class and the peasantry with his great and little traditions. Both Hall and Scott are examining culture distinctions drawn between classes of society and while this is useful, it is not sufficient for the examination of conflict in Northern Ireland.

In Northern Ireland, the local-folk perspective is defined by the everyday experiences of conflict. It is presented as the 'real' experiences of the people, as opposed to the official perspective promoted by the governing elite. This distinction is highlighted in the way that some scholars approach the conflict of Northern Ireland. Paul Dixon's analysis of the conflict stresses "two, inter-connected wars being fought..., the 'real war' and the 'propaganda war'. The real war is aimed at winning advantage through physical means, violence, demonstrations and repression. But these are also deployed in the propaganda war to shift the political agenda. The ideological, public rhetoric of the propaganda war by various parties to the conflict can be contrasted with the 'realities' of the conflict which are often only privately acknowledged" (Dixon 2001: 1). Dixon's summary of the real and propaganda wars emphasizes the duel nature of the process of perspectives at work within Northern Irish society. The 'real war' is 'fought' everyday on the streets of Northern Ireland at the intersections of identity, ethnicity, power, and 
class. The local-folk perspective is (re)defined by these interactions. In turn, the official perspective encompasses the propaganda war through the employment of cultural domination and the (re)defining of heritage to the likes of those in power.

The official and local-fold perspectives influence the narrative(s) presented to the outside world. Places where narratives conflict present a problem for tourism. The tourist industry often presents the official narrative to the public. Local-folk narratives are not hidden at places of conflict. Instead local-folk perspectives challenge the official narrative by presenting their own narratives. In some points in time, and in certain places, these narratives/perspectives are prevalent, distinct, and seemingly at odds with one another. At other times (and places) the narratives/perspectives seem to fade from importance; in these cases the sides of the conflict blur into one another and show that they do not always stay within the bounds and categories in which we put them. The blurring of lines between perspectives demonstrates how seemingly oppositional ideologies are not always mutually exclusive despite being in conflict with one another. The same is true for the presentation of heritage and culture for touristic consumption. The official narrative tends to closely follow unionism, the dominant sector of society, while local-folk narratives flow from both nationalist and unionist ideologies.

Nationalist and Unionist identities are not given. They are formed, constructed and reimagined along the lines of a number of recurrent themes: (1) Identity is constructed from perceived differences with other groups of people. Usually those differences are highlighted due to a supposed threat from the 'Other'. (2) In order to create a distinction between themselves and the 'Other', significance is given to certain aspects of culture that are absent from the cultural practices of the 'Other'. (3) The group 
will then chose an identifier for themselves, a name that holds some cultural significance.

(4) Finally a common history is created through the "selective use and reframing of traditions of pre-existing groups, or the simple invention, from scratch, of 'ancient' roots"' (James 1999: 137-138). Identity is complex and ever-changing. There are no universal definitions of 'Catholic', 'Protestant', 'Unionist', 'Nationalist' etc. Instead, these terms are in constant flux and are reformed through interactions throughout time and space.

Christianity was brought to the island by Saint Patrick and other early Christian missionaries who aided in the assimilation of the Irish peoples' traditional religion around 432 CE (Davies 1996: 263). By the $12^{\text {th }}$ century, Ireland was made up of rival kingdoms that were invaded by the Normans shortly after they established rule in England. Ever since, a portion of Ireland has been under English control. Henry VIII's establishment of the Anglican Church in 1534 divided England and her territories according to religion. England became Protestant, while Ireland and, to a lesser extent, Scotland remained Catholic. In 1609, the era known as the plantation of Ulster, an organized effort to colonize the northern region of the island during the reign of James I began. Protestants, mostly Scottish Presbyterians, settled in the region on lands confiscated from the local Gaelic population. At this time Protestant land ownership rocketed from 5\% to over 80\% (Dixon 2001: 3). From this time onward, Northern Irish politics would be dominated by a Protestant-unionist agenda.

A North American understanding of Protestantism and to a lesser extent Catholicism cannot be applied to the Irish, mainly because American views have tried to separate the Church and the State. Joseph Ruane and Jennifer Todd give a description of the Protestant community in their book, The Dynamics of Conflict in Northern Ireland; 
"Class divisions are underplayed by unionists and loyalists in favor of the notion of a single Protestant community - the 'unionist family' defending itself from its enemies and owing allegiance to Britain. Traditional institutions and practices - the Orange Order, ritual marches, service in the armed and security forces of the state - serve at once to integrate different groups of Protestants and to fuse their religious, cultural and political views: for many Protestants, Britishness is synonymous with Protestantism and unionism, or difficult fully to distinguish from it" (1996: 63).

The Northern Irish unionist narrative is, for the most part cohesive, Protestant-unionists are a tight knit, unified political community despite class divisions. While conflict can arise, it has not been allowed to cause dissent and ultimately fracture the community. Instead, the main political parties, DUP and Ulster Unionist Party (UUP), appeal to all aspects of the community rather than focus on just a part (Ruane 1996: 64). Unionist cohesion stems from the perceived need to defend the community from the nationalist threat.

In the past, the Northern Irish Protestant mindset included a siege mentality. "As the 'natives' revolt, loyalists refurbish their most durable myth, that of the besieged garrison" with little to no hope of reinforcements from the 'motherland' as motivators of self-reliance (O’Dowd in Rolston 1999: 47). They view themselves as alone in a hostile environment, and find strength in political cohesion. By actively seeking to quash any potential schisms within the Protestant community through the careful control of the official narrative, unionist political organizations have strengthened the unionist political position in Northern Ireland, and maintained the ruling majority.

While there is cohesion in the Northern Irish Catholic community at large, political differences have slowly worn a hole in the fabric of the community. There is one overarching nationalist official narrative, to unite the island of Ireland, yet the 
Catholic community splits on how to achieve this goal. The two major parties, Sinn Féin and the Social Democratic Labour Party (SDLP) both work towards a united Ireland, but at very different paces. The former calls for rapid change, and in the past was tied to more extreme forms of nationalism - republicanism and the Irish Republican Army. The latter works within the power-sharing process for an eventual unification with the Republic of Ireland. Sinn Féin was born out of a fracture of the IRA in the early 1970s, but it distanced itself from the organization in the late 1970s. (Ruane 1996). Since the 1970s, the Catholic community's attitude towards political violence has changed from acceptance/complacence to disapproval.

The fracturing of the Nationalist-Catholic community has stalled the fight for independence or any form of change. Despite this, the current political atmosphere does not change the community's feelings towards the past and the trespasses of their 'ethnic English' counterparts. Over time, politico-religious separation has bled into social norms and created separations that are present in the spatial layout of urban areas. These separations are present in the negotiation of these spaces through the construction of socially informed mental maps. These mental maps have their origins in the segregation that resulted during the Troubles. Mental maps are socially and experientially constructed conceptual landscapes formed by a person that includes the boundaries of personal territory, perceived 'dangerous' and 'friendly' territories, and other key elements of the social and physical surroundings that contribute to that person's safe navigation of their everyday encounters. Each mental map is unique because it is internally constructed through experience. Mental maps persist today because segregation continues in the cities and villages across Northern Ireland. 
Space and Place: A Northern Irish Interpretation

The social schisms in Northern Ireland have affected the negotiation of space, where mental maps become a crucial part of a person's every day interpretation of sociophysical interactions. Mental maps rank neighborhoods according to political/religious alignment and their relative safety. They are found in barriers constructed to keep certain populations out of an area. In urban communities such as Belfast, neighborhoods are segregated by class, and throughout times of conflict, separated by religious and political alignment, creating "sealed communities" (Harvey 1996). In sealed communities, place is "a closed terrain of social control that becomes extremely hard to break once it achieves its particular permanence" (Harvey 1996: 312). In 1969, as a result of rioting, a segregation of communities took place. People uprooted themselves or were forced from their homes and became refugees in their own city. While segregation was the past response to violence, the construction of the first makeshift barriers during the 1969 riots marked a shift in how people responded to violence in their communities.

Rubbish bins, pieces of abandoned homes and construction materials were used to create barricades between 'opposing' neighborhoods. This created an interface/sanctuary zone that normalized violence and created a new spatial paradigm (Figure 2$)^{5}$. The barricades and the surrounding areas became the stage for violence. Bricks, Molotov cocktails, bombings and machine gun fire were everyday occurrences near the barricades. This area became a no man's land of abandoned burnt out homes.

\footnotetext{
${ }^{5}$ Figure 2 is based off of Allen Feldman's sanctuary/interface model (1991: 35) with a
} more illustrative touch in relation to Belfast. 

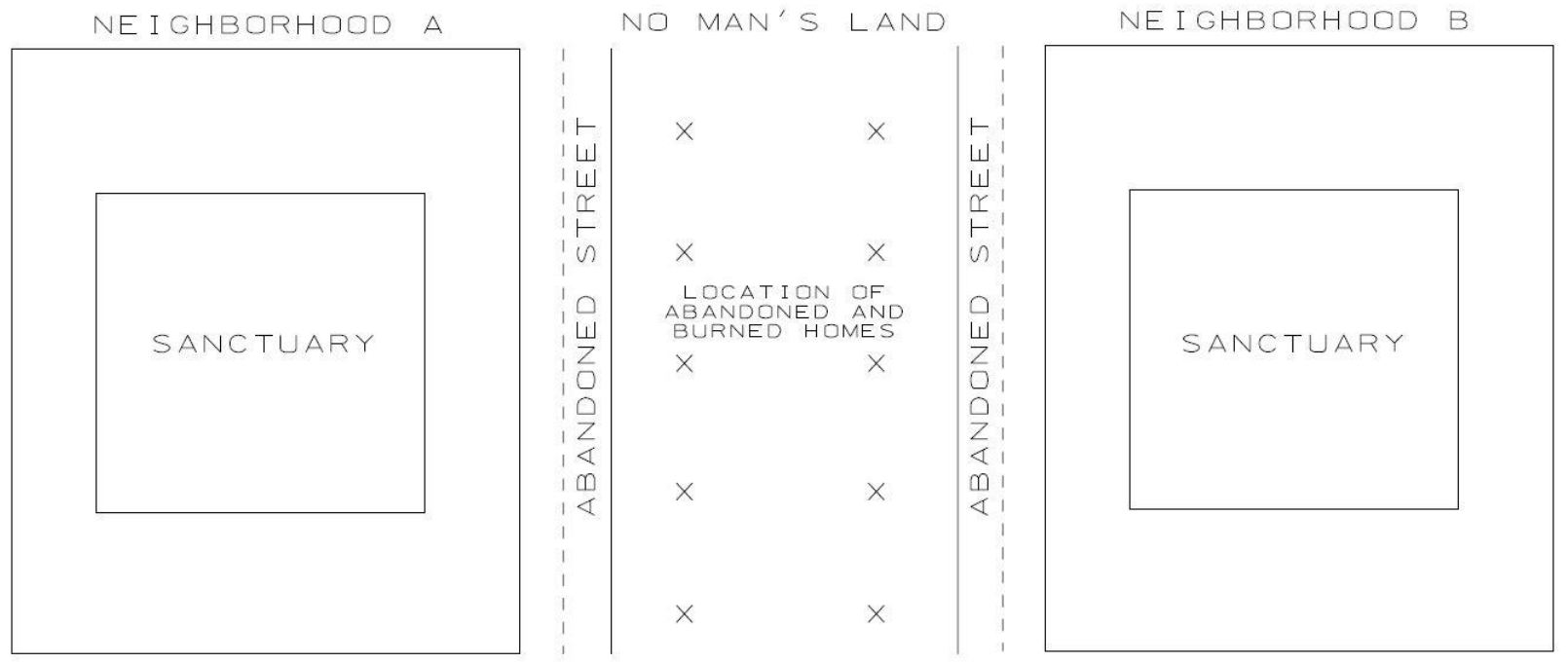

$$
x=\text { BARRIER }
$$

\section{Figure 2: The creation of the Interface/Sanctuary}

Sense of place grows from more than direct spatial experience. Social rumor and news media make their contributions as well. Begoña Aretxaga recounted how a female faculty member of Queens University in Belfast reacted negatively when asked about the Falls, a Catholic neighborhood in West Belfast with ties to the IRA. The woman had never been to West Belfast, but she urged Aretxaga to stay away as well: "The Falls is on the other side of the city, but [sic] I wouldn't go there. It's not safe; something may happen to you. I wouldn't go to the Shankill [a loyalist Protestant district in West Belfast] either; you are quite safe in Belfast if you don't go the Falls or the Shankill” (Aretxaga 1997: 32). While the woman's apprehension was not shaped by first-hand experience of the 'rough' neighborhoods, rumor and media were powerful influences on the creation of her mental map. Areas such as the Falls and the Shankill had been heavily occupied by the British army during the Troubles. This was because of the neighborhoods' associations with various paramilitary organizations. The Shankill was patrolled and protected by the UVF, while the IRA, and later the Provisional Irish Republican Army 
(PIRA) claimed the Falls as their territory. Social action and the power of social rumor and news media have shaped sense of place in Northern Ireland.

The history of British presence in Ireland reinforces unionist claim to the land. As the culturally dominant community, the Protestant dominant Unionists shape and validate their claims to physical space, "as the community which formed Northern Ireland in its own image, they have the material symbols of their past and present throughout the public spheres" (Ruane 1996: 201). Conversely, the Irish nationalist sense of place is a territorial and emotional response to British colonialism. The most obvious explanation is the reclamation of land lost during colonization or the protection against further loss, thus the careful separation from the 'Other' community occurs as a natural response and furthers the segregation of the larger community. It is linked to the notion of legitimacy, and whose claim to Ireland is 'more secure'. Since the colonization of Ireland, ethnic Irish have been portrayed as wild heathens whose claim to the land is irrelevant because of their sub-human qualities (Aretxaga 1997: 90-93). The nationalist community has fought against this depiction through the rejection of British sovereignty. This rejection is a way for nationalists "to defy the arbitrariness of a superior power, [and] reassert their dignity and political legitimacy" (Aretxaga 1997: 86).

With the expansion of the economy, political spaces and conflict-scarred places have been repurposed into tourist attractions that put the history of sites on display for all to see. As tourism transforms places of conflict, the process of (re)defining space changes. Meanings assigned to space may evolve during the transition to tourist attraction, but the transformation also creates a liminal place within the segregated community. Conflict tourist attractions within certain territories allow for the passage of 
previously excluded individuals. Following Victor Turner's liminal phase of a rite of passage, liminal space affords visitors a certain amount of ambiguity (Turner 1978: 249). The transformation of conflict zones into tourist space is a part of a broader touristic movement, and will be further examined in the following chapters.

The official narrative of history is often utilized as context for the explanation of the sectarian conflict to the visitor. Below is a brief explanation of the official historical narrative presented to visitors to Northern Irish heritage sites. Since the beginning of the peace process, exhibits, collections and museums dedicated to the events of the Troubles have been established. Most of these exhibits examine the Troubles and attempt to offer an explanation. Most of the museums and exhibits were not established solely with tourism in mind. They are also marketed as educational and heritage sites. The events described below are subjects of many of the exhibits in Belfast and Derry/Londonderry as key episodes of the sectarian conflict during the Troubles.

The Civil Rights Movement and the Troubles: $1969-1993^{6}$

The civil rights movement in Northern Ireland was inspired by the American Civil Rights Movement. It was spearheaded by the Northern Ireland Civil Rights Association (NICRA). In Northern Ireland during the mid-1960s, civil rights activists fought against discrimination against Catholics. NICRA published its own constitution on 9 April 1967 stating "its objectives:

1. To defend the basic freedoms of all citizens

2. To protect the rights of the individual

\footnotetext{
${ }^{6}$ Unless otherwise specified, main historical sources include Ulster Museum Troubles exhibit and Museum of Free Derry.
} 
3. To highlight all possible abuses of power

4. To demand guarantees for freedom of speech, assembly and association

5. To inform the public of their lawful rights" (Hennessey 1997: 137).

More specifically NICRA called for the disbanding of the Ulster Special Constabulary (B-Specials), and for the repeal of the Special Powers Act (1922) that allowed for the internment of 'known' nationalist and republican activists. Advocates also protested employment and housing discrimination and the gerrymandering of electoral boundaries. The first civil rights march took place on 24 August 1968 from Coalisland to Dungannon ${ }^{7}$. Even though the march was officially banned, it went on without incident and encouraged the formation of protesting groups in other counties.

In early October a civil rights march was organized in Derry/Londonderry, about $112 \mathrm{~km}(70 \mathrm{mi})$ northeast of Belfast ${ }^{8}$. Marchers met resistance from a group of loyalists and a fight broke out. Following the march, violence erupted in the Derry Bogside neighborhoods that lasted for two days.

The following year the People's Democracy, a civil rights group formed by students at Queen's University, staged a protest march from Belfast to Derry/Londonderry. Approximately 40 marchers left Belfast on 1 January. Their numbers swelled to several hundred over the course of four days. The protesters were attacked 8km (about $5 \mathrm{mi}$ ) outside Derry/Londonderry at Burntollet. Over two hundred loyalists, including off duty B-Specials, attacked the protesters with stones, iron bars and wooden sticks hammered through with nails.

\footnotetext{
${ }^{7}$ Coalisland is $6.4 \mathrm{~km}(4 \mathrm{mi})$ northeast of Dungannon in County Tyrone. Both towns are approximately $64.4 \mathrm{~km}(40 \mathrm{mi})$ west of Belfast.

${ }^{8}$ See Figures 3 and 4
} 


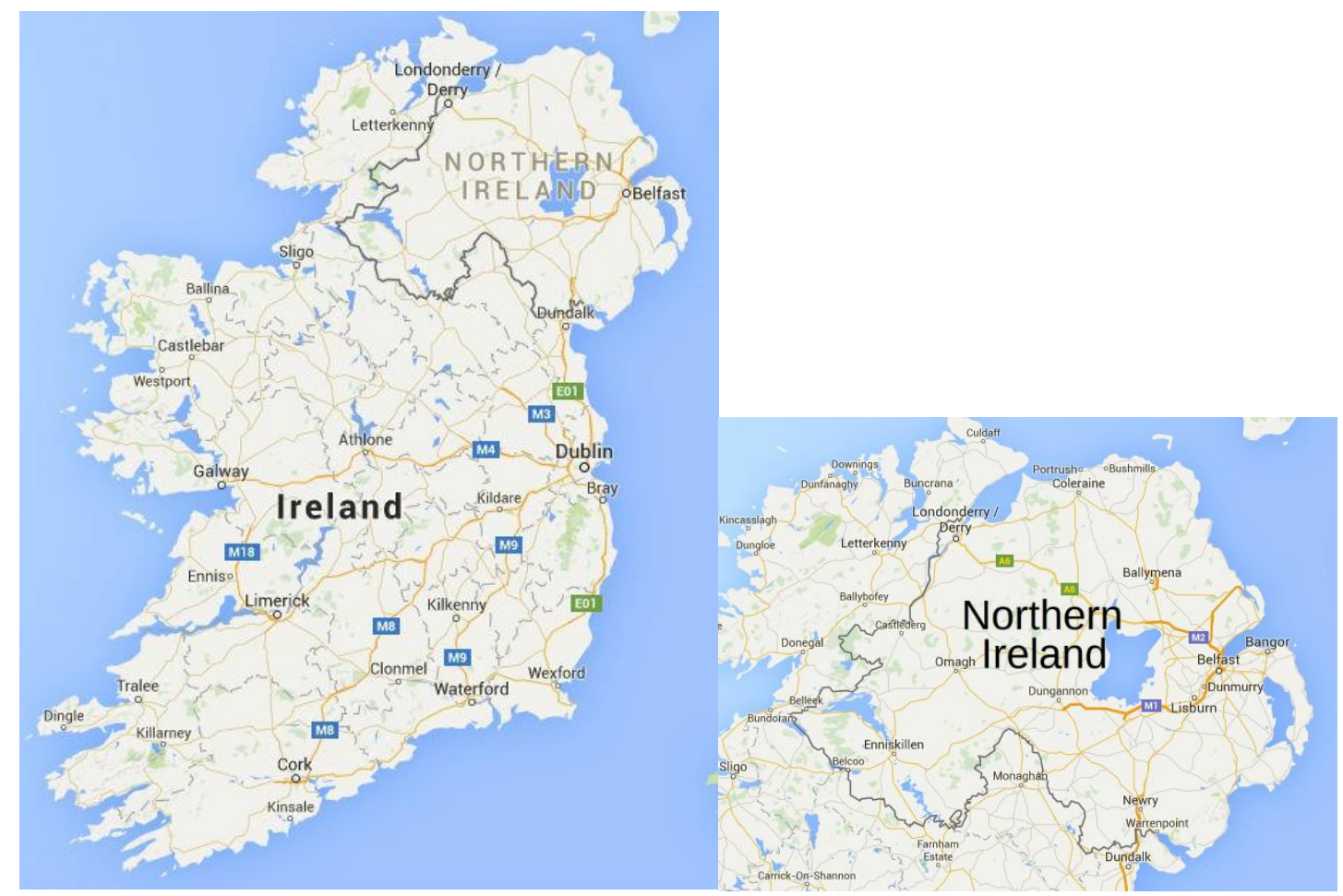

Figure 3 and Figure 4: Map of the island of Ireland and detail of Northern Ireland. Source: Google Maps.

Royal Ulster Constabulary (RUC) officers broke up the protest as it entered Derry/Londonderry. The area became a flashpoint of violence after RUC officers entered the Bogside. The incident spurred the residents of the Bogside to seal off the neighborhood with makeshift barricades. In an act of defiance, the area was declared "Free Derry". A standoff between residents of the Bogside and the police lasted eight months, with incidents of increased violence in April and July.

\section{Northern Ireland Riots 1969}

On 12 August, the Apprentice Boys parade passed near the Derry Bogside and was pelted with stones and other projectiles by Catholic residents. A few hundred RUC officers armed with CS gas, water cannons and firearms entered the Bogside shortly after 
and a two day clash, called the Battle of the Bogside, began. The next day, 13 August, rioting erupted across Northern Ireland. In Belfast, a group of nationalist youths assaulted the Hastings Street RUC station, and rioting spread throughout north and central Belfast. In response, the RUC deployed riot police in armored cars into the city. Makeshift barricades were created to hinder RUC officers' access to Catholic areas. Many people living in or near the interfaces of these blockades fled their homes.

Fighting continued on 14 August and was heavily concentrated in the FallsShankill neighborhoods. While RUC officers and loyalists were trying to enter a Catholic area on Dover Street, IRA members opened fire on the crowd, killing one civilian and wounding three officers. Soon after, RUC officers opened fire with a Browning machine gun into the Divis Tower flats, killing two people.

In the early afternoon of 15 August, the Northern Ireland cabinet requested military aid. Combat continued near the Clonard monastery where a band of loyalists burned homes on Bombay Street, Kashmir Road, and Cupar Street. George McAuley, a fifteen year old member of the Fiann, an IRA youth organization, was killed by a loyalist sniper while he helped people escape their burning homes. The British military moved into the area and subdued the loyalist attacks with tear gas.

Other towns in Northern Ireland were engulfed in rioting from 13-16 August as well. Across the region 8 people were killed and over 750 were injured in the riots. There had been isolated instances of rioting and fighting in the past, so why did the violence intensify on 13 August 1969? Prior to the riots, unionists were becoming extremely uncomfortable with the advances NICRA was making. Power-sharing and equal rights were viewed as threats to their power, and old fears of besiegement 
resurfaced. If left unchecked, equal rights would ultimately lead to a nationalist majority and a break with England. These feelings of insecurity intensified unionist determination and their sense of nationalism. This nationalism was evident in the increased frequency of Orange Order and Apprentice Boys parades that marched through the streets of Belfast and Derry/Londonderry.

Nationalists and Catholics were frustrated by the resistance of the unionist government to equal rights. Encouraged by other global examples, they began to voice their demands through protests and demonstrations. When protests were attacked by loyalists, nationalists and Catholics noted that the police forces did not step in and protect them. This damaged the RUC and B-Specials' credibility within the Catholic and nationalist communities. As a result, these communities increasingly looked inward for policing and protection. The police forces' loss of credibility was interpreted among unionist and Protestant communities as a preference among Catholic and nationalist communities for the IRA.

When rioting began in Derry/Londonderry on 12 August, the RUC was illequipped to handle the outbreak (Hennessey 1997: 163). The deliberate staging of protests and demonstrations in other areas of Northern Ireland on 13 August spread RUC officers thin. Even with the help of the B-Specials 300 active members and 8,200 volunteers, the police force of about 3,200 was overwhelmed (Hennessey 1997: 163). When it became evident that the police force would not gain control of the situation, the Northern Ireland cabinet looked to England for help. The deployment of British troops into Northern Ireland on 16 August 1969 began Operation Banner which officially lasted until 31 July 2007. 
Operation Banner, Politics, and Internment

Operation Banner was the name given to the British armed forces' occupation of Northern Ireland. Its primary role was to assert the authority of the government of the United Kingdom. The armed forces were to support the police force in keeping the peace and fighting insurgency. They deemed the latter half of their mission complete in 1972 when the PIRA was demoted from insurgent to terrorist status after the events of Operation Motorman, discussed below.

By 1971 a number of political parties and paramilitary organizations had formed. In 1969 the IRA fractured into two sects: PIRA and Provisional Sinn Féin, and the Official Irish Republican Army (OIRA) and Official Sinn Féin ${ }^{9}$. The split occurred when Sinn Féin leadership decided not to engage in violent warfare against the British. Members of what became PIRA and Provisional Sinn Féin were not satisfied with the defensive stance taken by their leadership and called for aggressive action. PIRA became the largest and most active paramilitary organization during the Troubles.

Before 1971, there was only one loyalist paramilitary organization, the UVF. The group was established in 1966 and took its name from a previous organization, the Ulster Volunteers, who fought Irish separatists in the 1910s. Their goals included maintaining Northern Ireland's connection with the United Kingdom and defending against Irish nationalism. The Ulster Defence Association (UDA) was established in September 1971 as an overall organization for loyalist defense groups operating within Protestant neighborhoods. Their initial goal was to defend Protestant neighborhoods from IRA

\footnotetext{
${ }^{9}$ Sinn Féin had a relationship with the IRA that began in the 1930s. The party has traditionally been thought of as the political arm of the IRA. Official Sinn Féin was renamed in 1970 as The Worker's Party of Ireland.
} 
violence. However, the organization soon shifted focus to an offensive plan of action and created the Ulster Freedom Fighters as a cover group to carry out violent paramilitary attacks.

Internment was introduced in July 1971 and lasted until December 1975. In the first major raid in August 1971, 342 people were arrested on suspicion of IRA involvement. The majority of those arrested had no association with the IRA. The raids incited four days of rioting throughout the region which resulted in the deaths of 20 civilians and the displacement of thousands of others. No raids were made in loyalist areas until 1973. Between August 1971 and December 1975, 1,874 Catholic/Irish nationalists were detained while only 107 Protestant/loyalists were held (CAIN archives).

\section{Bloody Sunday (1972)}

On 30 January 1972 an unauthorized march of thousands of nationalists took place in the Derry Bogside. The march was organized by MP Bernadette Devlin to bring waning attention back to the civil rights movement and to protest Internment. British troops set up barriers and redirected the protest to the roundabout near Rossville Flats. A small group of youths broke away from the main protest and proceeded towards the military's barrier on William St. The small group attempted to pass through the barrier in order to continue on to the Guildhall, the original destination. Denied access, the group began throwing stones at the barricade and the troops stationed behind it. As the crowd near the barricade grew, troops used tear gas and water cannons to attempt to disperse them. In the following confusion, the soldiers were given orders to enter the Bogside and open fire. 
Fourteen people were killed and fourteen more wounded as the protestors ran from the military's advance. Following the events, official reports stated that the soldiers opened fire in response to gun fire and nail bombs directed at them. Eye witness reports from protestors, residents and reporters ${ }^{10}$ covering the march stated that the troops fired upon an unarmed crowd. Evidence of the OIRA sniper, bullets or nail bombs were never found directly following the event. An inquest into the happenings gathered by Lord Chief Justice, Lord Widgery just eleven weeks later, found the Army's actions justified, despite testimony and evidence to the contrary.

Anglo-Irish relations worsened after the British armed forces arrived in Northern Ireland. Initially the Catholic community welcomed the military, hoping they would protect them from Protestant mobs and the RUC. However, opinion began to change after rumors of the military forces' collusion with loyalist paramilitary organizations spread throughout the Catholic and nationalist communities. The introduction of Internment and repeated raids in Catholic and nationalist neighborhoods further deepened these communities' mistrust of the military. In the aftermath of Bloody Sunday, relations between Catholics and nationalists, and the British government was at an all-time low.

\section{Operation Motorman}

By July 1972, there were 29 barricades blocking police, army and loyalist paramilitary access to Catholic/nationalist areas in Derry/Londonderry. These were termed no-go areas. In Northern Ireland, a no-go area was a barricaded zone where residents prevented British Army and RUC officers from entering. Other no-go areas had been created or stabilized in other towns and cities. In May, the OIRA announced a

\footnotetext{
${ }^{10}$ The nationalities of the reporters present varied including English, Irish and French.
} 
ceasefire, stating that they would only resort to violence in defense of their territories. PIRA, on the other hand, went on the offensive and detonated 22 bombs throughout Belfast on 12 July 1972. Eleven people were killed and 103 injured in the attacks. The British Army devised Operation Motorman as a response, and in the pre-dawn light of 31 July, 22,000 troops breached the barricades of no-go areas in Belfast, Derry/Londonderry, Newry, Armagh, Lurgan and Coalsisland. Republican forces within the areas did not attempt to resist the British troops as they flooded into Catholic and nationalist neighborhoods.

In Derry/Londonderry two people were killed and two others wounded in the operation. At Bishop's field Seamus Bradley (19), an unarmed PIRA member, was shot as he climbed a tree. He bled to death from his wounds before receiving treatment. By the end of the day the areas were cleared of 'no go' zones. Operation Motorman was considered a success and marked the beginning of a more permanent military presence within Catholic and nationalist neighborhoods. After this time permanent military check points and construction of today's peace lines, 21 inconsecutive miles of wall, began. Initially, the barriers were a strict attempt to stem the encroaching violence or "reduce the capacity of communities to assault each other" (Shirlow 2006: 67). The peace lines and the establishment of military check points along the length of the walls at entrances to Catholic communities immobilized the Catholic and nationalist populations in Belfast and other Northern Irish cities.

\section{The Sunningdale Agreement 1973}

Direct rule from Westminster was established in March 1972 with the dissolution of the Parliament of Northern Ireland. After the events of Bloody Sunday, Westminster 
deemed Northern Ireland's Parliament unfit to handle the continuing violence and demanded rule be turned over to them. In 1973 working under the assumptions that a moderate majority existed within Northern Ireland but remained stifled by extremist views, Westminster attempted to set up a power-sharing Assembly and Executive.

The Northern Ireland Constitution Act 1973 abolished the Parliament of Northern Ireland and the office of Governor. In their place a devolved administration was set up: The Northern Ireland Assembly and the Northern Ireland Executive. As a result of the June 1973 elections, the UUP won majority (39.8\%; 24 of 78 seats). However, the SDLP gained the first significant number of seats for a nationalist party in a Northern Irish governing body (24.4\%; 19 of 78). Despite this, opposition to power-sharing was such a problem that when talks began with the British and Irish governments, only the propower-sharing parties ${ }^{11}$ were invited to Sunningdale, Berkshire on 6 December 1973. Three key issues were discussed: (1) The status of Northern Ireland, (2) the Council of Ireland, and (3) Policing jurisdiction. The status of Northern Ireland has long been contested, with both the British and Irish governments claiming the territory. A concession was made by the British government that it would support a majority vote on the status of Northern Ireland, whether it be to continue its association with the UK or to become a part of the Republic. The second item discussed, the Council of Ireland, was to consist of 14 members, 7 from Northern Ireland and 7 from the Republic. The council's duties were not well defined and instead a four week study was proposed in which the functions of the council would be clearly defined and reviewed by both the Northern Ireland Assembly and Oireachtas ${ }^{12}$. Finally, in matters of policing, the Irish government

\footnotetext{
${ }^{11}$ UUP, SDLP, and Alliance Party of Northern Ireland

${ }^{12}$ Irish Parliament
} 
agreed to arrest and try those who committed "crimes of violence in Ireland, however motivated" (Dixon 2001: 144). This allowed for the arrest of IRA members whether they committed their "crime of violence" within Northern Ireland or the Republic. In response, the British government agreed to end Internment.

The Sunningdale Agreement was not well received by unionists and many political and paramilitary organizations actively worked to block its implementation. Unionists and loyalists were concerned with the influence the Irish government could exert over the Council and ultimately over Northern Ireland. The Council of Ireland and the introduction of a power-sharing Executive threatened unionist power and agitated loyalist paranoia.

The Northern Ireland Executive was established on 1 January 1974. It lasted five months before the Ulster Worker's Council strike, which lasted fourteen days, severely crippled many sectors of Northern Ireland's economy. Violent clashes between Catholics and Protestants developed across the region during the strike and spilled across the border into the Republic. By the fifth day, a state of emergency was declared.

The strike led to a governmental breakdown exposing the Executive's lack of power and its reliance on an increasingly reluctant British Labour government. Following the strike, direct rule was re-established and the Labour government reversed its position and endorsed the new surge of unionist patriotism. Westminster had underestimated the extent of extremist views in Northern Ireland, and ultimately powersharing failed at this time because of political polarization (Dixon 2001: 156). 
Constitutional Convention: 1975

After power-sharing failed, Westminster attempted a hands-off approach to the governmental problem. The power-sharing experiment had damaged the British government's credibility among unionists, and an anti-power sharing majority began to advance politically. Loyalist tendencies were on the rise as British power was threatened. The United Ulster Unionist Council (UUUC), a cross-party coalition of hardline unionists, was created in opposition to the Sunningdale agreement. In the rapidly polarizing political environment, the UUUC quickly gained power. In the May 1975 elections for the Constitutional Convention, its candidates won $54.8 \%$ (47 out of 78 seats). The Convention recommended a governmental set-up similar to the Parliament of Northern Ireland. Instead, the Labour government continued direct rule seeing no other way to introduce a power-sharing governmental plan. As tensions rose in the political arena, violence on the streets worsened.

\section{Prison Protests}

In 1972, Paramilitary prisoners were awarded political prisoner status, and with this given greater freedom of movement, the right to wear ordinary street clothing and other special privileges. As part of the criminalization of paramilitary organizations in 1976, the revocation of political status downgraded paramilitary inmates to regular criminal inmates. When the prison uniform was introduced to paramilitary inmates in September, many newly convicted prisoners refused to wear them, instead wrapping themselves in prison blankets. The movement was labelled the blanket protest and despite efforts to end the protest through the further loss of privileges, it persisted into 1977. 
The Relatives Action Committee (RAC) was formed in 1976 by the mothers and wives of the increasing number of nationalist prisoners. Members of RAC "deployed suffering as a weapon" (Aretxaga 1997: 117). They drew upon the misery of their sons and husbands, and their own grief as mothers and wives separated from their loved ones (Aretxaga 1997: 117). Wrapped only in blankets, RAC members protested outside Westminster in London, the White House in the US, and participated in the UN conference on women of 1978 (Aretxaga 1997: 117). By emphasizing their own experiences, RAC members helped bring international attention back to Northern Ireland.

The blanket protest evolved into the dirty protest in early 1978. 300 Protestors refused to leave their cells to wash or to use the toilet. Despite the growing number of prisoners participating in the protest, the British government remained unmoved and no status change took place.

As international media attention focused upon Northern Ireland, seven republican prisoners, led by Bobby Sands, a former PIRA leader, began a hunger strike on 1 March 1981. Five days into the strike Frank Maguire, Independent Republican MP for Fermanagh and South Tyrone, died. Sands was nominated for the vacant position in the by-election, and after the SDLP's withdrawal of its candidate, faced only the Unionist candidate. Sands won the election. His victory failed to move Margaret Thatcher, who made her position clear in the statement: "We are not prepared to consider special category status for certain groups of people serving sentences for crime. Crime is crime is crime; it is not political" (Hennessey 1997: 261).

23 people went on hunger strike throughout 1981. On 5 May, Sands died. Between 12 May and 20 August, nine more hunger strikers died. The strike officially 
ended 3 October 1981. Officially, Thatcher's Conservative government condemned the hunger strikers and their cause, but due to international pressure, closed doors meetings were arranged with their representatives. All of their demands, except the right not to work and Special Category Status, were met.

The hunger strike is a clear example of how official and local-folk narratives can work at odds with each other. The official narrative touted by the British government outlined the conflict as a multipronged struggle; communal (unionist versus nationalist), terrorist (state versus international subversion) and criminal (police versus psychopaths) (Dixon 2001: 188). Republicans and some nationalists represent the struggle as between an oppressive, foreign colonizer and the IRA "freedom fighters" (Dixon 2001: 188). The hunger strike and its preceding protests were considered, by republicans and many nationalists to be struggles for freedom. Generally the conflict is referred to as a communal struggle, between Protestant and Catholic or unionist and nationalist. When speaking of more specific incidents the violence enacted is characterized as either terroristic or criminal. By 1981 the government favored the criminalization narrative and used it to forward policies such as non-concession.

Hardline unionism continued to dominate the political realm in the late 1970s and early 1980s. The DUP made steady gains in elections at the local, regional, national and international levels, while moderate leaning organizations were seeing declining results at the polls.

\section{The Anglo-Irish Agreement 1985}

The threat of civil war and international pressure led the Conservative government of Britain to form the Anglo-Irish Inter-Governmental Council on 6 
November 1981. The Irish government proposed introducing an Anglo-Irish police force and court system to Northern Ireland. The Irish government hoped to ease tensions in the area and to stop the alienation of nationalists (Dixon 2001: 192). Though Thatcher

rejected the proposal, "the 'central concept' of the Anglo-Irish Agreement was established: firm, and formal Irish acceptance of the Union (though without the repeal of Articles 2 and $3^{13}$ of the constitution) as a basis from which the Irish Government, on the behalf of the nationalist minority in Northern Ireland, could be given a systematic and institutionalised influence on British decision-making there without any diminution of British sovereignty" (Dixon 2001: 193).

The Anglo-Irish Agreement gave Ireland a consulting role within the Northern Irish government. As part of the agreement, the British-Irish Intergovernmental Conference was established. It was responsible for security, economic, social and cultural matters. Also, an allowance was made for the establishment of a devolved, power-sharing assembly to take over these responsibilities in the future (Dixon 2001: 197). The Anglo-Irish Agreement was signed on 15 November 1985 by Margaret Thatcher and Irish Taoiseach ${ }^{14}$, Garret Fitzgerald.

Unionists considered the Anglo-Irish Agreement further proof of Britain's long term plan to pull out of Northern Ireland. Soon after the signing, 250,000 unionists protested the Agreement. A year later, on 10 November 1986, the Ulster Resistance movement was established during a loyalist meeting. Those present included Ian Paisley and Peter Robinson, a rising star within the DUP. On the one-year anniversary of the signing of the Agreement, 200,000 protestors gathered to voice their displeasure, and the protest escalated into rioting in loyalist areas (Dixon 2001: 205).

\footnotetext{
${ }^{13}$ The second article of the Irish constitution (1937) claimed the entire island of Ireland as national territory. Article 3 claimed sovereignty over all peoples born on the island of Ireland.

${ }^{14}$ Equivalent to a Prime Minister.
} 
Continued Unrest: 1986-1996

Throughout the early to mid-1980s, Sinn Féin continued to strengthen the distance the party had created between itself and the IRA in 1975. Bobby Sands and Owen Carron's successful elections ignited a renewed republican interest in the political arena and under the leadership of Gerry Adams, Sinn Féin began making significant political gains.

The success of Sinn Féin's political campaign was proving that the tide could be changed politically, instead of through continued violence. By 1994, Northern Ireland's civilians were weary of violence and were open to new strategies. On 31 August, due to pressure from the community and political organizations, PIRA issued a ceasefire and in October of the same year the Combined Loyalist Military Command declared a ceasefire for all loyalist paramilitary organizations.

The year following the ceasefire agreements was relatively free of sectarian violence. Attention shifted to talks of a peace process as members of Sinn Féin began meeting with members of the Northern Ireland Office and with President Bill Clinton of the United States. On 30 May 1996, elections were held for the Northern Ireland Forum, a body set up as part of the negotiation process that would led to the Belfast (Good Friday) Agreement. Sinn Féin made steady gains in the election, but the results pointed to the continued polarization of the Northern Irish community.

In May 1997, Britain's newly elected Labour Government took office. Led by Tony Blair, it immediately focused attention on the state of Northern Ireland and began to maneuver Sinn Féin and the unionist parties into talks. US General George Mitchell was instrumental in creating the document called the Mitchell Principles. The document laid 
out a number of rules for the ensuing peace talks including disarmament of all paramilitary organizations. The peace talks lasted from September 1997 to April 1998.

\section{The Good Friday Agreement}

The Good Friday Agreement was signed on 18 April 1998. It built upon the policies proposed in the failed Sunningdale Agreement: "both agreements were based upon the idea of a combined governmental structure that would involve the British government, Irish government and a Northern Irish assembly" (Ben-Porat 2006: 203).

Several social transformations happening in Northern Ireland facilitated the development and acceptance of the Good Friday Agreement as a viable option for the creation of peaceable cooperation: (1) the changing demographics of the population, notably the ratio of Protestants to Catholics had dramatically changed since 1971 from 63:37 to 58:42 in 1991. (2) The static economy created by the conflict was further aggravated by the deindustrialization of the region, and needed revitalization. (3) Support for the activities of the various paramilitary organizations was declining as there appeared to be no end to the conflict through violence. (4) The election of moderate nationalists in the Republic of Ireland reflected changes in political power. (5) The rise of the Labour Party, brought new players willing to tackle the issues of Northern Ireland's conflict. (6) Finally, broader changes influenced political and economic decisions being made on the island. These included: the strengthening of the European Union's (EU) power, the end of the cold war, and globalization (Ben-Porat 2007: 203-204). Such conditions did not mean that the Agreement lacked critics. However, the critics were not united. 
The Peace Process: 1999-2015

The peace process is ongoing. The Good Friday Agreement stipulated the creation of a devolved power-sharing government made up of The Northern Ireland Assembly and The Northern Ireland Executive. Disagreements between the DUP, UUP, and Sinn Féin, now the largest nationalist party, have blocked further advancement of the devolution process. First elected in June 1998, the Assembly has been suspended on four occasions: February to May 2000, 10 August 2001, 22 September 2001, and October 2002 to May 2007. These hiccups in the governmental process agitated the communities and rearmament has taken place amongst many paramilitary organizations. These groups have focused their sporadic attacks on Police Service of Northern Ireland (PSNI; formally RUC) stations and military posts.

The government resumed operation in May 2007 and completed the first full term in March 2011. General elections of the current officials were held in May 2011, and the new Assembly convened in the same month. The Northern Ireland Executive is the administrative branch of the Assembly. The DUP currently has the most seats at 38 . Sinn Féin is close behind with 29 seats and the SDLP and UUP hold 14 and 13 seats respectively. There is still a split within Northern Irish society as illustrated by the election. However, nationalist parties have steadily been gaining seats since the 1970s.

Socio-political schism is still present in Northern Ireland, and perpetuates conflict despite the peace process. The schism informs identity and the negotiation of social and physical space through mental maps. However, the schism in Northern Ireland is not a clear, direct oppositional break. The official and local-folk perspectives inform one another and upon first look appear averse to one another. In actuality the perspectives 
blur together across time and space during the process of (re)formation. This process will be further examined in chapter three within the analysis of conflict sites in Belfast and Derry/Londonderry. The next chapter explores the evolution of the process of tourism in Northern Ireland and its relationship to conflict. 


\section{CHAPTER 2}

\section{HISTORY OF TOURISM ON THE ISLAND OF IRELAND}

Tourism, as defined by the United Nations World Tourism Organization (UNWTO), "is a social, cultural and economic phenomenon which entails the movement of people to countries or places outside their usual environment for personal or business/professional purposes. These people are called visitors (which may be either tourists or excursionists; residents or non-residents) and tourism has to do with their activities, some of which imply tourism expenditure" (UNWTO website). The UNWTO's definition of tourism is broad and hinges upon visitor motive, but also notes payment. A resident or local can be defined as a tourist through motivation and the tracking of tourist dollars. The resident temporarily becomes a tourist by visiting and spending their money at local sites of tourist consumption: museums, zoos, and attractions. The tourist, like Turner's liminar, occupies a liminal space in society, allowing them to move semi-freely within social structures and locales that are very different from their own home spaces (Turner 1978: 249). The tourist is allowed to bend the rules of regular social norms because of their temporary status as a guest.

Understanding conflict tourism requires comprehending the conflict of Northern Ireland as a broad process, examining tourism as a process, and analyzing specific tourist sites. Despite the 'inherent contradiction' of tourism and conflict, an economy supported by the tourism industry can thrive. In fact, regions like Northern Ireland illustrate that the 
'contradiction' of tourism and conflict is more like a dialogue. I will not argue that the presence of violence does not impact tourism, in fact, it inhibits most kinds of tourist growth in an affected region. However, conflict, particularly a non-violent struggle between opposing forces, can coexist with tourism. Especially with the rising demand for "unique and interesting" cultural heritage sites.

The marketing of conflict sites is a recent development in the process of tourism in Northern Ireland. They have their origins in the socio-political processes at work before and during the economic revival. Their transformation and appropriation as tourist sites is a part of the long history of tourism on the island.

\section{$\underline{\text { Tourism and the Island }}{ }^{15}$}

Ireland became an important site for the English tourist with the emergence of the romantic tourist gaze in the late $18^{\text {th }}$ century, and uneven industrial development that left most of the island pastoral in appearance. Ireland languished on the socio-economic and political periphery of the United Kingdom. It was an agricultural colony, specializing first in crops, like the potato, and much later in raising cattle for consumption. In Industrialized areas such as Dublin and Belfast, textile production flourished (Hechter 1975; Zuelow 2009). Ireland's economy was tied to the British economy, where the marketability of Irish products depended on the demand from Great Britain. As a result, Ireland's industrialization process was uneven and late coming. Technological advances in transportation in the late $19^{\text {th }}$ and early $20^{\text {th }}$ centuries, although not perfected, made

\footnotetext{
${ }^{15}$ Historical sources of tourism in Ireland are from Furlong (2009) and Zuelow (2009) unless otherwise noted.
} 
travel across the island much easier and faster, thus opening up the island to the casual visitor.

Ireland became a tourist destination after an important shift occurred during the Romantic era where 'the natural as beautiful' became the dominant ideology of the upper classes. Ireland as a tourist destination was popularized in this era by poets, like Oliver Goldsmith, who wrote about pastoral Ireland, and philosophers such as Edmund Burke whose "notion of the 'sublime' helped to redefine what cultured Europeans found aesthetically pleasing" (Zuelow 2009: xx). Places that were previously viewed as dangerous or unappealing were looked upon with renewed interest. Beaches, mountains, lake lands and even the tumbled down ruins of past villages and strongholds were "reimagined as scenic rather than as eyesores" (Zuelow 2009: xx).

Tourist development in Ireland began after the mass tourism market evolved out of the aristocratic Grand Tour. Tourism was used as a platform to further the improvement of the Irish infrastructure and transportation, and educational systems. Tourism's importance to Ireland's/Northern Ireland's economic welfare will be examined below including its transformation over the past 170 years.

\section{Tourism Growth: 1840-1914}

Popular tourism has its roots in the aristocratic Grand Tour. In the mid-seventeenth century, the sons of wealthy English families would travel abroad in Continental Europe for several months or years. In order to educate themselves in the latest in politics, arts and science, the young men would immerse themselves in the cultures of other European nations. By the late eighteenth century, education became less important to the young aristocrat whose focus shifted to having a prolonged pleasurable experience. By this 
time, some prosperous merchants and professionals could afford a shorter tour of the Continent, but it wasn't until the late 1830s, when technological advancements in communication and transport allowed for faster, easier and cheaper travel. "As railways extended their networks across Britain and industrialization created a new class of urban workers searching for an escape from their everyday environment, the material and social conditions to enable the ordinary man to 'get away from it all' were in place" (Furlong 2009: 9).

By the 1840s, Romantic authors and poets such as Wordsworth, Byron and Keats had firmly established the coasts and wild lands of Britain as desirable locations. In 1841 Thomas Cook organized his first trip for teetotalers to attend a temperance rally in Longborough, England. Cook saw potential in his endeavor and began to develop and perfect the concept of the package tour. By the end of the nineteenth century Cook had established Thomas Cook \& Son and offered packaged tours to groups of British tourists all over the British empire, including Ireland (Furlong 2009: 9).

Queen Victoria's visit to Ireland in 1843 boosted the island's popularity in the following years and essentially put Ireland on the map for tourism. Hotels, resorts and the development of pleasure spots began along the rail lines, the Royal mail coach lines, and the south and western coasts. (Furlong 2009: 18). The promotion of Ireland as a tourist destination was spearheaded in the 1890s by an Englishman named Frederick W. Crossley. Crossley came to Ireland as an employee of Thomas Cook \& Son, and when he could not convince his employer of the economic potential of Irish tourism, he took up the project alone. In 1891, Crossley left Thomas Cook \& Son and "founded the Irish 
Tourist Development Association with the object of bringing together all those in the country who stood to benefit from its tourism potential" (Furlong 2009: 19).

Crossley's efforts to establish Ireland as a popular tourist destination led to the improvement of the transportation systems, hotels and accommodations, and the preservation of natural and historic sites. However, not everyone viewed tourism as a suitable economic solution. R.A.S. MacAlister, saw tourism as a detriment to Irish culture. He wrote of tourism as the harbinger of destruction for Irish antiquities and an endeavor that would crush the soul of the Irish peasant (Furlong 2009: 26; Zuelow 2009: xxi). MacAlister's argument emphasized a problem within nineteenth and early twentieth century tourism in Ireland - poverty. It was thought that many well to do visitors to the island were coming to gaze upon the abject and romanticized poverty they had read about in the novels of prominent Irish authors.

To combat these issues, Crossley lobbied the Irish local and British national governments for improvements to the transportation systems and pushed for legislation that was favorable to the tourism industry, including the Railways (Ireland) Act of 1896 and the Health Resorts and Watering-Places (Ireland) Act in 1909 (Furlong 2009: 13). He also focused on cultivating the image of Ireland by founding a publishing company that produced the journal, Irish Tourist. Crossley launched an advertising campaign touting Ireland as the perfect place to holiday, with emphasis on "the scenic and sporting attractions" (Furlong 2009: 20). Further technological developments in transport, especially automobiles and motorcycles, would bolster tourism for Ireland after the turn of the century. 
By the opening of the $20^{\text {th }}$ century, visitors not only came from Great Britain, but also North America. Tourists came for various reasons. They viewed the natural beauty exalted by the Romantic writers, spent time golfing or enjoying other sporting activities advertised in various tour publications, or rediscovered their cultural roots.

Tourism had a problematic relationship with Irish nationalism. It intensified and compounded Irish nationalism and by 1900 many Irish had become disenchanted with foreign visitors. Members of the Ulster Association and the newly formed Gaelic League viewed tourism as a threat to Irish identity; the exposure to English, Scottish and American visitors was watering down Irish culture and destroying the preservation of the Irish language. Queen Victoria's enmity towards Ireland was well known in the United Kingdom, and increased resentment towards the monarchy ${ }^{16}$ (Furlong 2009: 28-31). Growing nationalist sentiment and the outbreak of the First World War effectively brought tourism to a halt. Tourism was virtually nonexistent on the island during the War of Independence (1919-1921) and despite efforts in the North after partition in 1921, the Irish Civil War perpetuated the view of Ireland as a dangerous place.

Northern Irish Tourism: 1880-1980 17

Before the mid-twentieth century the north of the island was not well developed for tourism, unlike the south and west. By the 1820 s the advancements in steam technology opened the Irish Sea between Belfast and Liverpool for regular steamer services. By the 1860 s services were extended from Belfast to more English and Scottish

\footnotetext{
${ }^{16}$ Victoria would compare Ireland to Scotland and often commented on how the island was found wanting. She was once quoted as saying that no one would go to Ireland for amusement, and the royal family's visits were suffered in the name of duty.

${ }^{17}$ Unless otherwise specified, main sources include Furlong (2009) and Zuelow (2009).
} 
cities. The opening of the region led to improvements in rail and road, and the potential of tourist developments were discussed in earnest by the 1880s. The focus of tourist development began in County Fermanagh in the west, a region dotted with picturesque lakes and hills. Then it moved along to the Coast of Antrim, in the northeast, with emphasis on the Giant's Causeway, the largest lava plateau in Europe ${ }^{18}$. At the same time, Henry McNeill of Larne began packaging tours along the Antrim coast to the developing resorts at Newcastle, Bangor, Whitehead, Larne, Ballycastle, Portrush and Portstewart. In April 1896 an Ulster tourist committee was formed and headed by Belfast lord mayor W.J. Pirrie. The committee in a joint effort with Frederick Crossley lobbied against proposed legislation that would close off the Giant's Causeway and charge guests admission. Despite their efforts, the bill passed but not to the detriment of tourism to the Antrim Coast. Instead, the proposing organization made many improvements to the region, including the creation of a walkway that winds through the bays and passes along the prominent features of the Causeway, and the electric railway that carried tourists to the Causeway from Portsrush (Furlong 2009: 25). As in the south of Ireland, tourist developments came to a halt at the beginning of the First World War and would not resume until after partition.

Tourism became an important endeavor in the inter-war years, with the creation of various committees and organizations devoted to the promotion of tourism. The Ulster Tourist Development Association (UTDA), a non-governmental committee, took residence in its first offices in Donegall Square, Belfast in 1924. The group's objectives were to promote Northern Ireland as a tourist destination to potential visitors from Great

\footnotetext{
${ }^{18}$ The Causeway is connected to nearby Rathlin Island (approx. 13km(8mi) across the Sea of Moyle) and Scotland's Staffa Island (approx. 129km(80mi)) where the basalt structures reemerge from the sea.
} 
Britain. By 1928 efforts were made to ensure Northern Ireland's inclusion in British tourist publications and representation in touristic governing bodies, such as the Travel Association of Great Britain (Furlong 2009: 135). Tour operators reminded potential British visitors that Northern Ireland was a part of the United Kingdom, and there were no travelling restrictions between Northern Ireland, England, Scotland and Wales.

During the 1930s the established tourist bodies began lobbying the government for the establishment of a statutory tourism body for Northern Ireland. However it wasn't until 1937 that "a government committee was set-up to consider accommodation, amenities and facilities for tourism, as a result of recommendations by the UTDA that the potential of the industry should be closely and officially investigated" (Furlong 2009:

137). Despite these advancements, the declaration of war in September 1939 once again halted all official government work on tourist expansion.

Despite the war, the UTDA continued its touristic promotions focusing its attention on internal tourism, on visitors from the Republic and on the Ulster-based troops. Ever the forward-thinking organization, the UTDA's advertising to American and British troops stationed throughout Great Britain and Northern Ireland was a campaign to entice soldiers to spend their leave in tourist destinations and to create a lasting impression. The hope was that soldiers would remember the brightly colored posters displayed in various bases or their leave in Northern Ireland and would wish to holiday there after the war.

After the war, tourism in Northern Ireland was slow to take off. In 1948 the government recognized the need to direct touristic endeavors and created the Northern Ireland Tourist Board (NITB) under the Development of Tourism Traffic Act and 
replaced the UTDA. The NITB was overseen by the Minister of Commerce but functioned as an independent organization "empowered to inspect, register and grade accommodation, and to provide grant aid to local authorities and private enterprise wishing to invest in tourism development" (Furlong 2009: 139). The NITB's list of duties was long and in the first decade of its existence overwhelmed the moderately staffed organization. The board was charged with various tasks: overseeing hotels and resorts, investigating potential touristic opportunities, gathering information and statistics on current tourist traffic, and promoting Northern Ireland as a tourist destination to other parts of the $\mathrm{UK}^{19}$. During the 1950 s the NITB produced an advertising campaign, including the viewing of $\mathrm{BBC}$ documentaries and speaking tours promoting the beauty of the region. There was also a push to make Northern Irish resorts more competitive with those in the Republic, and to a lesser extent in England. One way to compete was to offer package tours to singles or couples instead of just focusing on the family holiday.

A study conducted by the NITB in the mid-1950s found that tourism was stunted due to the lack of proper government funding, the region's position in the scheme of international travel, and growing political unrest. The NITB suggested a collaborative project with Bord Fáilte, the Republic's principle tourist organization, in 1965 as a way to rejuvenate tourism in the region. The venture was initially resisted by the unionist government because it encouraged an all island cooperation that was viewed as boosting nationalist sentiment. Even though it got off to a rocky start, the collaborative effort resulted in relaxed border crossings, the establishment of a joint information center stationed at the border, and promotion of the island as a whole. The joint effort boosted

\footnotetext{
${ }^{19}$ At this time international tourism promotion was handled by the British Travel Association.
} 
Northern Irish tourist numbers from the Republic and internationally until 1969. The outbreak of violence in Belfast and Derry/Londonderry sparked negative media attention internationally and tourism declined again. The NITB turned its attention to countering the negative media by launching a public relations campaign that emphasized the friendliness of the Irish and focused on the promotion of rural areas away from Belfast and Derry/Londonderry.

In the 1970 s the political unrest in the region continued to diminish tourist numbers. In response, the NITB focused on promoting the region to the Northern Irish and emphasized home holidays. The scheme was a financial success, drawing in $£ 95$ million on home holidaying (Furlong 2009: 156). By the late 1970s, however, a recession coupled with the continued political unrest lead to further drops in tourist traffic. Despite the efforts of the NITB, between 1980 and 2000 no major advances in tourism were made (Furlong 2009: 158).

\section{Resurgence: 1990-2001}

The NITB once again joined forces with Bord Fáilte in the mid-1990s in an effort to brand and promote the whole island. The result was the 1996 campaign "Tourism Brand Ireland". Further collaboration was blocked, however (Zuelow 2009). Again, as in the past, initial attempts to work in partnership with the Republic's Bord Fáilte was met with resistance from the unionist faction of government, the UUP. During the 1998 peace talks that lead to the Good Friday agreement, British prime minister Tony Blair "began pushing for the establishment of cross border cooperative bodies" (Zuelow 2009: 222). Popular opinion in Northern Ireland varied along political lines, with nationalists viewing the establishment of cooperative bodies as a balancing of power with the 
unionist majority, and unionists opposing such measures for the same reason. It was at this time that the UUP objected to the formation of a cooperative tourism body, claiming that funding for such an endeavor would disproportionately benefit the Republic. Despite unionist objections, by 18 December 1998 an agreement had been reached on the creation of six cross-border bodies including tourism (Zuelow 2009: 222-223). A seventh unofficial body was included and "would be created through the merger and privatization of the Northern Ireland Tourist Board and Bord Fáilte" (Zuelow 2009: 223).

In late 2000 Tourism Ireland Ltd. was created and tasked with the international promotion of the island as a whole. Tourism Brand Ltd. executes the promotional campaigns developed by the NITB and Bord Fáilte and works cooperatively with the two national boards. NITB and Bord Fáilte which "retain control over marketing domestic tourism, research and planning, niche marketing, regional marketing, the implementation of sports-tourism initiatives, festivals and cultural events, the grading of premises, and the development of sustainable tourism" (Zuelow 2009: 223-224). Beginning in the mid1990s, minor advances were being made in tourism, but the outbreak of foot and mouth disease $^{20}$ in Great Britain in February 2001 wreaked havoc upon tourist numbers in Ireland.

In order to prevent a possible outbreak of foot and mouth disease in the Republic of Ireland, the Irish government "shut down the countryside and many attractions. Livestock could not be moved, hill walking was banned, national parks were closed, angling was stopped, and equestrian sports were forbidden" (Zuelow 2009: 227). Essentially, the Republic was closed to tourism and this shut down affected tourism in

\footnotetext{
${ }^{20}$ Also referred to as hoof and mouth disease
} 
Northern Ireland. The terrorist attacks on New York's World Trade Center on September 11, 2001 further impacted already low tourist numbers. Of course this was felt more in regions that relied on tourism as a major source of national income, regions like Northern Ireland and the Republic. A drop in tourist numbers meant lost jobs in both regions (Zuelow 2009: 228). Ever resourceful, the NITB once again turned its focus inward and promoted home holidays, a campaign that continues in 2015.

\section{Rebranding Northern Ireland: 2004-2007}

After 1999 changes were implemented in the handling of tourism in Northern Ireland. The NITB was a non-departmental public body of the Department of Enterprise, Trade and Investment (DETI) and its responsibilities were redefined as developing the tourism experience, promoting the region to domestic and Republic of Ireland markets, and advising DETI on policies that affect the tourism industry. The NITB and Tourism Ireland Ltd work together on projects and in setting number targets. After a slump in tourism post-9/11, the NITB recognized that the market was changing and that in order to keep up, Northern Ireland would have to cultivate unique, sustainable sight/sites and attractions as well as to develop their marketing presence both at home and abroad.

In 2004, the NITB produced the Strategic Framework for Action 2005-2007. The document was written as a basic plan of action that identified overall goals for tourism growth for the next three years. NITB and Tourism Ireland Ltd planned to work in cooperation with VisitBritain, the DETI, the Department for Regional Development (DRD), the Department of Employment and Learning (DEL), the Department of Culture, Arts and Leisure (DCAL), Northern Ireland Tourism industry Confederation (NITIC), the Tourism Training Trust (TTT), Invest NI and other regional tourism companies. The 
objectives included increasing tourism revenue by $9 \%$ and visitor numbers by $7 \%$ each year and boosting Northern Ireland's share in all island tourism. In order to achieve these goals three overall objectives ${ }^{21}$ were identified. (NITB Strategic Framework 2003: 3). Ten programs were designed in order to reach the objectives laid out in the action plan. Four of the programs focused on Attracting Visitors. The first, "Know the Visitor" focused on market research developing better research techniques on visitors. Research completed by the NITB prior to 2004 pointed to a changing market: the typical visitor was increasingly over the age of 55, pressed for free time and interested in the environment, which pointed to an increase in short breaks, or weekend holidays mainly by visitors from the domestic, UK and Republic of Ireland (RoI) markets (ibid: 6). The second program, "Develop a Compelling Proposition," focused on rebranding Northern Ireland through tourism. In order to improve both the local and international image of Northern Ireland the action plan suggested hosting events on the local, regional and international scale, and journalist visits (ibid: 6). The third program "Reach the Consumer" aimed to better the placement of marketing campaigns through a three tiered approach that divided the market into domestic and high performing overseas markets (tier 1), competitive markets (tier 2), and future markets (tier 3) (ibid:7). "Take Care of our Visitors", the fourth program, sought to enhance visitor servicing through improvements to international access, including movement between Northern Ireland and RoI, and creating better access to information on Northern Ireland and its destinations (ibid: 7).

${ }^{21}$ Attracting visitors, enhancing business and effective communication 
The next four of the ten programs focused on enhancing the business of tourism. The first of these business programs, "Develop Signature Projects," pinpointed five potential sites for touristic growth. The plan identified the Giant's Causeway and Antrim Coastal area, Titanic (Maritime) Belfast, The Walled City of Derry, Christian Heritage: St. Patrick Trail, and the Mournes National Park as the potential sites. The Signature Projects were created and promoted as sites unique to Northern Ireland that would spark local and international interest in the region and raise visitor numbers (ibid: 8). "Focus on Winning Themes," the second business program, outlined five areas of current and potential tourist growth: Short breaks, Events, Business tourism, Activity tourism and Culture and Heritage Tourism (ibid: 8). The Short Breaks ${ }^{22}$ section focused on the domestic, UK and RoI markets and concentrated on the improvement of information access and the creation of potential programs of visit for the weekender and short breaker. Securing and promoting local (Belfast Pride Festival) regional (Colmcille Pageant - Fleadh Cheoil) and international events (G8 Summit and Grande Partenza of the Giro d'Italia) were recommended in the Events section. Events were considered a motivation for visits and had the potential to increase the regional and seasonal spending of visitors (NITB Corporate Plan 2005-2008 2005:11). The Business Tourism section recognized the business traveler as a potential for growth. This section recommended improvements to conference and convention centers and the promotion of certain types of sites — accommodations, services (restaurants) and activity (golf) — to this genre of visitor. Activity Tourism focused on the sporting visitor interested in golf, angling, hiking/walking, cycling, etc. The section recommended creating sites competitive with

\footnotetext{
${ }^{22}$ Defined as lasting no longer than 5.3 nights (NITB Corporate Plan 2005-2008 2005: 11)
} 
those in other European markets focused on the "variety and distinctiveness of Northern Ireland's natural resources" (NITB Strategic Framework 2003: 8). Finally, the Culture and Heritage Tourism section indicated a need to promote this type of tourism domestically and internationally with emphasis on Signature Projects. The third business program, "Develop Internationally Competitive Businesses," was a jumping off point for the Tourism Development Scheme that would be created in 2005. The focus was on the creation of short term, mid-term and long term schemes that would regulate and develop customer services and sites. The resulting Tourism Development Scheme laid out a funding program where the NITB could distribute funds to projects that "assisted with the delivery of Signature Projects" and/or "develop an internationally competitive destination" (NITB Tourism Development Scheme 06/08 2005: 6). Eligible projects included those that sustained or extended the tourist season, created visitor servicing and interpretation centers for Signature Projects, enhanced or development trails, upgraded existing facilities to enhance their appeal or accessibility, supported or enhanced international gateways ${ }^{23}$. Also included were environmental projects that enhanced tourist sites (ibid: 6). "Deliver Memorable Experiences," the fourth and final business program, outlined a need for improvements to the hospitality sector. These improvements included setting a standard of operation, creating and improving hospitality/service training programs, and enhancing career development for those already working within the hospitality sector (NITB Strategic Framework 2003: 9).

The last two programs outlined in the Strategic Framework for Action aimed to foster effective communication, including inter-industry communication and marketing

${ }^{23}$ Ports and Airports 
and promotion. The first program, "Share Information," concentrated on effective marketing and promotion of achievements through "proactive PR activity" and showcasing success (ibid: 10). This included the creation of tourism and business awards that highlighted and "promote[d] best practices" (ibid: 10). The final program, "Strengthen Effective Relationships for Delivery," worked to create cohesive and cooperative business practices among the businesses and councils operating within the industry.

In its Corporate Plan for 2005-2007 the NITB laid out a number of key objectives and goals based off of the Strategic Framework for Action to be attained by March 2007. The key objectives included focusing on strengthening the NITB's position as the leader of the tourism industry in Northern Ireland, also included were attracting visitors, securing funding for tourism projects, internal corporate building, raising public awareness of Northern Ireland as a tourist destination, and improving and developing relationships with local/regional government agencies and Regional Tourism Partnerships (RTP). In order to reach these objectives, targets were set. Numerical goas were included. By 2007 NITB desired Northern Ireland to attract 24\% of all island visitors, increase visitor spending to $£ 419$ million, and increase domestic holiday spending to $£ 99$ million (NITB Corporate Plan 2005: 15). In order to achieve these goals, annual targets were established. The table below (table 1) illustrates the projected numbers the NITB hoped to achieve each year. The first portion of the table lists the desired increase in overseas guests by $7 \%$ each year. The second portion shows the desired increase in foreign visitor spending in pounds (£). In order to achieve these numbers the NITB and Tourism Ireland Ltd would have to diversify their target audience beyond Ireland, 
England and North America. The focus on business tourism and attracting events to Northern Ireland was outlined as a solution. The third and fourth portions of the table illustrate the desired increase in visitor numbers from the Republic of Ireland and the money spent by this category of tourist. The NITB hoped to appeal to potential tourists from the Republic by offering a cheaper option for holiday with an emphasis on short trips and event tourism.

Table 1: NITB Goals for 2005-2007

\begin{tabular}{|c|c|}
\hline \multicolumn{2}{|c|}{ Increase overseas visitors: 7\% growth per annum } \\
\hline 2005 & 1.854 million \\
\hline 2006 & 1.984 million \\
\hline 2007 & 2.123 million \\
\hline Increase overseas visitor spending: 9\% growth per \\
annum
\end{tabular}


The 2005 Corporate Plan stressed the importance of successfully implementing "Winning Themes" and "Signature Projects". In other words the marketing focus until 2007 would concentrate on promoting short breaks and business tourism, securing and promoting events, and creating or revitalizing sites unique to Northern Ireland.

\section{Signature Projects}

In order to attract visitors, domestic and foreign, and as a means to create sustainable tourist sites unique to Northern Ireland, the NITB created the Signature Projects. The Signature Projects was a short to medium term plan that proposed the creation of two new sites, Titanic (Maritime) Belfast and the Christian Heritage/St Patrick Trail, and the rebranding of three existing sites: The Giant's Causeway, Walled City of Derry and The Mournes Mountains. All were scheduled for completion in 2012. The sites would highlight culture, heritage and landscapes unique to Northern Ireland. First introduced in The Strategic Framework for Action 2004-2007, the Signature Projects plan was not fully developed and remained under-funded until 2008-2009 (NIAO Review 2010: 3-4). Because the NITB or DETI did not designate a board to oversee the implementation and management of the Signature Projects, performance has been hard to ascertain. The individual projects were actually developed separately and incrementally through a number of wider economic and social development plans (NIAO Review 2010: 3). Despite funding issues, the DETI identified the Signature Projects as the 'catalyst' for their long term tourism plans. Laid out in their Draft Term Tourism Plans for 2020, the DETI wished to increase visitor spending, the number of visitors, and 
the number of jobs in the tourism sector (table 2). The DETI goals were a part of governmental desire to increase tourism's contribution to the economy.

Table 2

\begin{tabular}{|c|c|c|}
\hline \multicolumn{3}{|c|}{ DETI Goals for $\mathbf{2 0 2 0}$} \\
\hline $\begin{array}{c}\text { Number of } \\
\text { visitors }\end{array}$ & 2010 & 2020 \\
\hline $\begin{array}{c}\text { Visitor Spending } \\
\text { Jobs in Tourism } \\
\text { Sector }\end{array}$ & $£ 536$ million & 4.5 million \\
\hline
\end{tabular}

The Northern Ireland Audit Office (NIAO) reviewed the progress of the Signature Projects in 2010. The NIAO found that the five main projects, considered to be separate ventures by both NITB and DETI, had a total of 106 sub-projects costing an estimated $£ 159$ million with $£ 71$ million provided by the public sector through NITB and Programme of Government funding (NIAO Review 2010: 9).

The initiation of the Strategic Framework for Action 2004-2007 and the Corporate Plan 2005-2008 changed the dynamics and direction of the Northern Ireland tourism industry. The focus on the "Signature Projects" and "Winning Themes" created an environment that allowed for the appropriation of conflict sites as tourist sites.

Implementation and Further Development: 2007 and beyond

The Northern Ireland Executive and DETI have identified tourism as a priority for development because of its contributions to the economy and its potential in the future. While tourism numbers have nearly doubled since the mid-1990s, tourism's overall contribution to the Northern Ireland economy was 4.9\% in 2009 (Deloitte 2010: 100). The NITB's Corporate Plan 2008-2011 defined goals and projects created from the 
tourist projections outlined by the Northern Ireland Executive in the Programme of Government. The key goals were to increase out-of-state revenue from $£ 370 \mathrm{~m}$ in 2006 to $£ 520 \mathrm{~m}(40 \%)$ by 2011 , and to increase the number of out-of-state visitors from $1.98 \mathrm{~m}$ in 2006 to $2.5 \mathrm{~m}$ (25\%) by 2011 (NI Executive 2007: 10). To achieve these goals the NITB emphasized certain projects and plans that needed to be implemented and certain areas of the industry that needed more development. Many of the same strategies were carried over from the previous corporate plan and framework for action: focusing on domestic, ROI and Great Britain markets, attracting events and business tourism, developing the Signature Projects and further expanding e-marketing.

In 2008, the Titanic Dock \& Pump House's restoration was completed and officially opened to the public. Work on the Titanic Signature building was also well in hand, but would not be completed until 2012. In Derry/Londonderry, restoration of St Columb's Cathedral was completed. The cathedral opened to the public in February 2009. It was an important part of the Built Heritage Programme within the Walled City of Derry Signature Project. Between 2009 and 2011 the main focus for touristic expansion in Derry/Londonderry was on the Walled City and the landmarks within it. The goal was to create a lively environment that highlighted architectural history and local heritage that provided an energetic nightlife featuring food \& drink, arts, the theatre and upscale nightclubs.

In 2007, the NITB identified four 'key product areas' in need for development: Cities, Culture \& Heritage, Sports Tourism Activities \& Waterways, and Business Tourism. The development of sports and business tourism is an expansion upon the previous plan's strategy, while the focus on cities and culture \& heritage is laid out in 
more detail. In an early introduction to these concepts, one area singled out for further development was labelled Unique Proposition. The Proposition stressed the importance of product development, specifically the "scope to further exploit key distinctive elements of our identity, culture and heritage in development and implementation of a branding strategy" (NITB 2007: 7). "Unique" is not explicitly defined within the Corporate Plan, nor is it clear what exactly the NITB means. However, from past emphasis on Signature Projects, one can infer that NITB is emphasizing the need to create or "exploit" sites that are 'one of a kind' or 'unlike any other'. The NITB is looking for new ways to commodify Northern Irish culture and heritage. By highlighting 'unique' aspects of culture and heritage, they are hoping to stand out from other tourist destinations. Uniqueness equates to pounds in the bank. By offering unique, "authentic" Northern Irish attractions, something no other culture can offer, NITB taps into a portion of the tourist market drawn to "cultural experiences".

In the action plan for developing cities as tourist products a number of suggestions were made including the need to "provide insight into the history and life of our communities" (NITB 2007: 11). The 2008-2011 Corporate Plan demonstrates a willingness to exploit every aspect of culture, history and heritage that Northern Ireland has to offer in an attempt to increase tourism revenue. Murals, memorial gardens, peace lines and sites of violent clashes were all viewed as potential products to be developed for touristic exploitation. These projects and sites will be further analyze in the upcoming chapter.

As a part of the search for "unique and different" sites, there has been an increase in the production of heritage sites in the past decade and a half. Ruins, castles, or other 
landmarks are no longer neglected and left to the whims of nature. Instead, these sites are maintained and renovated for touristic consumption. New museums and attractions are conceived and built to showcase numerous aspects of Northern Irish socio-cultural history. What sort of significance do conflict sites have in heritage tourism? In order to answer this question I compiled a list of heritage sites in Northern Ireland ${ }^{24}$.

There are several criteria I used to determine whether a site should be labelled as a heritage site; (1) The site was officially advertised with the keywords "history" and/or "heritage". (2) The site is listed as a National Heritage Site. (3) The site has historical significance, meaning key events in Northern Irish history occurred at the site. (4) It is an archaeological site, and/or (5) it is a site featuring characteristics that are unique to Irish/Northern Irish cultural heritage. Keeping all this in mind, the heritage site table in Appendix A was created from sites advertised in brochures, pamphlets and flyers collected on my 2013 trip to Northern Ireland. I further supplemented the list by searching the official tourist websites of Visit Belfast, Discover Northern Ireland, and Tourism Ireland. Name, site location, date (if applicable) and a description of the site are recorded. Of the 214 heritage sites, $21.5 \%$ (46) are conflict sites. That percentage is expected to rise as companies investing in tourism continue to exploit sites related to the sectarian conflict of Northern Ireland.

The following table (table 4) shows two things: (1) the percentage of sites built or created within three periods - prior to the Troubles (before 1969), during the Troubles (1969-1999), and after the Troubles (2000-2015). (2) When sites became active as tourist attractions.

\footnotetext{
${ }^{24}$ It is impossible to generate a complete list of every tourist site in Northern Ireland because of how quickly sites are created.
} 
Table 3: Creation of Heritage Sites

\begin{tabular}{|l|l|l|}
\hline Sites dating to before 1969 & Sites dating to 1969 -1999 & Sites dating to 2000 -2015 \\
\hline $\mathbf{7 4 . 8 \%}(\mathbf{1 6 0})$ & $9.3 \%(20)$ & $15.9 \%(34)$ \\
\hline $\begin{array}{l}\text { Sites active as tourist sites } \\
\text { before 1969 }\end{array}$ & $\begin{array}{l}\text { Sites active as tourist } \\
\text { sites starting in 1969- } \\
\mathbf{1 9 9 9}\end{array}$ & $\begin{array}{l}\text { Sites active as tourist } \\
\text { sites starting in 2000- }\end{array}$ \\
\hline $\mathbf{3 0 . 3 \% ( 6 5 )}$ & $11.7 \%(25)$ & $\mathbf{2 0 1 5}$ \\
$\mathbf{5 8 \%}(124)$
\end{tabular}

The table shows that most sites, $74.8 \%$ (160), were built or created before the Troubles. A heavy emphasis on heritage sites dating prior to the mid- $20^{\text {th }}$ century is consistent with most other heritage tourist destinations around the globe. Many destinations promote their "distant past", a time that both the presenting culture and the visitor are removed from. This allows the visitor to engage with the information at the site without having to confront fresh emotional and societal issues. Conflict sites in Northern Ireland, on the other hand, confronts the visitor with recent and/or ongoing events that bring the issues of the sectarian conflict to the foreground. At conflict sites the visitor cannot escape the immediacy of the conflict and its far-reaching historical roots, nor can they deny the influence that local public opinion has on these sites.

Furthermore, 58\% of the 214 heritage tourist sites recorded in Appendices A and B became attractions sometime after 2000. This increase is consistent with the recent activities of the NITB, and other governing bodies within the tourism industry, laid out in chapter 2.

The maps in Appendix B display all heritage sites, including conflict sites in Northern Ireland. Conflict sites are labelled by red pins and the rest of the heritage sites are labelled by blue pins. Two close-up maps of Belfast and Derry/Londonderry are also included. Belfast has the highest concentration of conflict sites as tourist sites with 43.47\% (20/46). Derry/Londonderry has the second highest concentration at 17.39\% 
(8/46). This is consistent with the events of the Troubles where the majority of the violence enacted during that period took place in both Belfast and Derry/Londonderry. Belfast also has the highest concentration of heritage sites $39.25 \%(84 / 214)$.

Derry/Londonderry has $9.8 \%(21 / 214)$ of all sites mapped.

By 2015, major work on the Signature Projects has been completed. They are open to the public. In fact, 3 of the 5 projects were among the top ten visitor attractions for 2014, with the Giant's Causeway and Titanic Belfast occupying the number 1 and 2 slots respectively and Derry's Walls coming in $4^{\text {th }}$ (table 3) (NI Statistics 2015: 14).

Table 4

2014 Top 10 Visitor Attractions - excluding country parks, parks, forests and gardens

\begin{tabular}{|l|l|}
\hline Attraction & Number of Visitors \\
\hline Giant's Causeway & 788,000 \\
\hline Titanic Belfast & 634,000 \\
\hline Ulster Museum & 466,000 \\
\hline Derry's Walls & 370,000 \\
\hline W5 & 324,000 \\
\hline Carrick-A-Rede Rope Bridge & 323,000 \\
\hline The Guildhall & 299,000 \\
\hline Belfast Zoo & 253,000 \\
\hline Pickie Fun Park & 243,000 \\
\hline Murlough Reserve & 241,000 \\
\hline
\end{tabular}

Eight of the top ten visitor's attractions in 2014 were heritage sites and four of those sites can be considered conflict sites. Titanic Belfast, Derry's Walls and the Ulster Museum 
will be further discussed later in this chapter and in chapter 3. Derry's Guildhall, located in Diamond Square was built in 1890 after the previous building burned in the mid-19 $9^{\text {th }}$ century. During the Troubles the Guildhall was the focus of multiple bombings, and in 1977 the building including its stained glass windows were restored. In 2000, the Guildhall was the site of the opening proceedings of the Saville Inquiry, a reexamination of the events of Bloody Sunday 1972. Formal public hearings were held for four months in the Guildhall before being moved to London. Today, the Guildhall and the surrounding square host events, concerts, and celebrations, including the Feis Doire Colmcille. The revitalization of the Guildhall and its recent use as an events site is a part of the city's revitalization project that began with the Walled City Signature Project.

The NITB means for the Signature Projects to improve Northern Ireland's international image by showcasing Northern Irish heritage seemingly untouched by the Troubles. For example the Mournes Mountain Trail and the Giant's Causeway are emphasized as natural wonders and "unique areas of special interest, rich in culture, heritage and mythology" (Discover Northern Ireland). The Mournes Mountains, and to a lesser extent, the Giant's Causeway, were highlighted in the NITB's Adventure tourism campaign, targeted towards adventurists and outdoorists as well as to those interested in the region's ancient history and local legends. At the Mournes, visitors walk the sites memorialized in Ulster and Fenian cycle stories of the heroes, Cuchuliann and Fionn Mac Cumhaill, and visit an array of tombs dating back 6000 years. The mythological origins of the Giant's Causeway is as much of a draw of visitors as its natural basalt wonders. Visitors photograph themselves with various natural structures like the 'giant's boot'. In reality a weathered basalt structure shaped like a large shoe, but legend has it that the 
Scottish giant Benandonner lost his boot fleeing from Fionn Mac Cumhaill. While the Giant's Causeway and the Mournes Mountains appear unmarred by the events and aftermath of the Troubles, the next three Signature Projects, Titanic Belfast, St Patrick Heritage Trail and the Walls of Derry are either conflict sites, or sites in conflict.

The last three Signature Projects all emphasis different periods within Northern Irish history, and while these sites are meant to highlight other parts of that history, the conflict is still present but not explicit.

Titanic Belfast (figure 5) was developed as a part of the waterfront revitalization program. The project commenced in the early 2000s with Harcourt Developments Ltd working in conjunction with "the Belfast Harbour Commissioners and Belfast City Council...[to] establish a charter for a progressive mixed-use development along the Lagan - homes, shops, hotels, offices, entertainment, education, and cultural amenities" (Costecalde 2012: 5). The attraction is situated on the site of the old Harland and Wolff shipyard where the sister ships RMS Titanic, RMS Olympic and HMHS Britannic were built. An interactive museum shaped like the prows of four massive ships conjoined in the center, tells the story of the construction of the Titanic and her sister ships as well as the maritime history of Belfast at the turn of the century (Titanic Belfast website). In his introduction to the souvenir guide, Pat Doherty, chairman of Titanic Belfast Ltd and Harcourt Developments Ltd, states that the attraction's mission “is to educate people about Belfast's maritime and industrial heritage" (ibid). In conjunction with Doherty's statement, Eric Kuhne, a design architect with the company that designed the museum, claims "Titanic Belfast is a touchstone for four centuries of Belfast's maritime legacy and commemorates those many thousands who built the great ships of Belfast...[The site] 
does more than teach us about its heritage, for it also teaches us about ourselves"

(Costcalde 2012: 7)

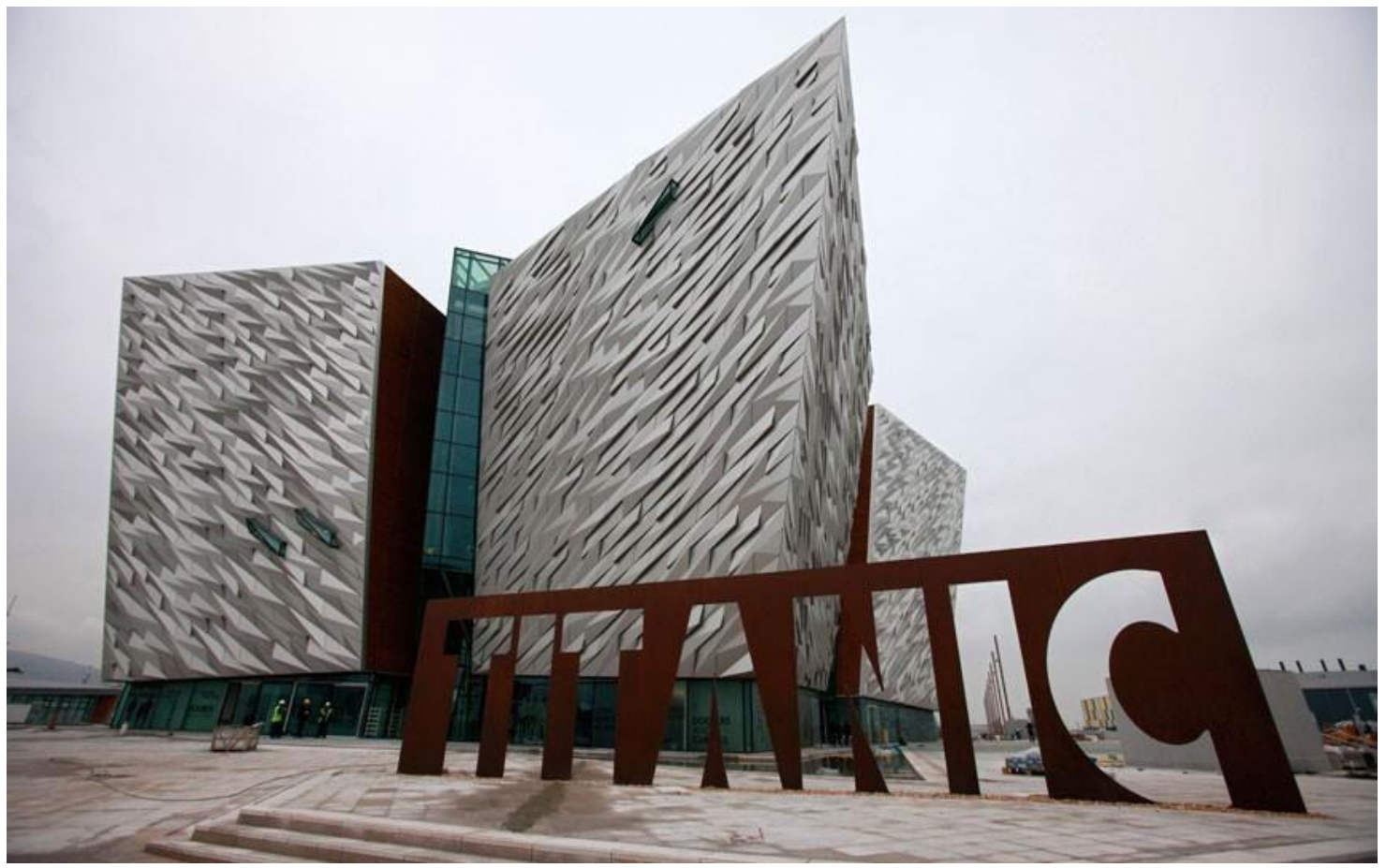

Figure 5

Titanic Belfast opened on 27 March 2012, and in its first year attracted 800,000

visitors, $58 \%$ of whom came from outside Northern Ireland. The revitalization of the docklands, renamed Titanic Quarter, was led by the installation of the Titanic exhibits. The area is now home to a growing corporate and residential space. The success of Titanic Belfast has revitalized maritime tourist attractions, like the SS Nomadic, HMS Caroline and the Belfast Barge. Despite this success, I classify Titanic Belfast as a site in conflict. Officially, the site has nothing to do with the sectarian conflict of the region. However, locally inhabitants of Belfast discuss the site's influence on visitors' understanding of Belfast's industrial history and the role sectarian politics played in shaping that history. Nationalists and Catholics are concerned about the lack of political discussion within the site's presentation of history. This concern can translate to 
disapproval of the site as a whole. Titanic Belfast's classification as a site in conflict will be further discussed in chapter 3. The St Patrick Heritage Trail presents another example of how sites can seemingly have no connection to the sectarian conflict, but nonetheless remain in conflict.

St Patrick's Trail is a 92 mile driving route that takes the visitor to 15 important sites of "Irish Christian heritage" (Discover Northern Ireland). The sites all have a link to St Patrick's life or his legacy in Ireland. The trail can be considered as both a tourist site and pilgrimage trail for Irish Catholics. The language used on the website, brochures and other media promoting the sites are religiously neutral in the sense that they refer to the sites as Christian heritage sites. While St Patrick's Trail is not a conflict site, it could be considered a site in conflict. The careful use of religiously neutral language on media promoting these sites show an awareness of the continuing conflict within Northern Ireland, and are clues to the fragility of the peace process. From a more economic perspective, religiously neutral language does not alienate the sites from one, rather large, group of potential visitors, non-Catholic Christians. The sites are promoted as a part of Northern Ireland's connection with St Patrick, a religious and historical figure. However their religious importance is emphasized as only a part of these places' history.

The Walled City of Derry is the original layout of the city that has grown into Derry/Londonderry. Derry/Londonderry had been a focal point for sectarian violence throughout the Troubles. In fact the city offers the visitor a distinctive perspective on the conflict. The city is the oldest continuously inhabited community in Ireland. It was founded as a monastery in the $6^{\text {th }}$ century. The oldest sector of the city, including its famous walls has been transformed into a historical and shopping district as part of the 
Signature Project plan (figure 6). The city spread beyond the original walls and across the banks of the River Foyle in the $17^{\text {th }}$ century during the Plantation of Ulster (figure 7 ) (Derry Londonderry 2013). Since the Ulster Plantation era (1609), the city of Londonderry was a protestant majority settlement, but as of the 2011 Census that has changed. Higher Catholic birth rates, and Protestant emigration has shifted the balance of power in the city. Catholics outnumber Protestants on both banks of the River Foyle with the neighborhoods of the east back at just over $50 \%$ and those of the west bank "in excess of 80\%" (Mullan 2013).

This shift in power also changes the city's official narrative from a unionist dominated perspective to a nationalist one. This is important in the presentation of sites within Derry/Londonderry, especially conflict sites. Conflict sites have been an important part of the city as heritage sites and as tourist attractions since the economic revitalization. Unlike most interpretations within Belfast that offer the neutral tones of the official narrative, sites at Derry/Londonderry have a nationalist-biased tone. Further discussion of Derry/Londonderry conflict sites are presented in the following chapter.

The Walled City project revitalized the city center into a shopping and arts district encircled by a historic site. The project, spearheaded by the NITB and their official agenda, emphasized Derry/Londonderry's growing arts and culture scene. While the nearby Bogside was already a popular tourist attraction with those who wished to learn more about the Troubles and the peace process, the Walled City Signature Project was meant to create more tourist attractions unrelated to the Troubles. The hope was to attract more domestic visitors and those interested in art, music and culture, essentially diversifying Derry/Londonderry's tourist audience. In 2013 the city became the UK 


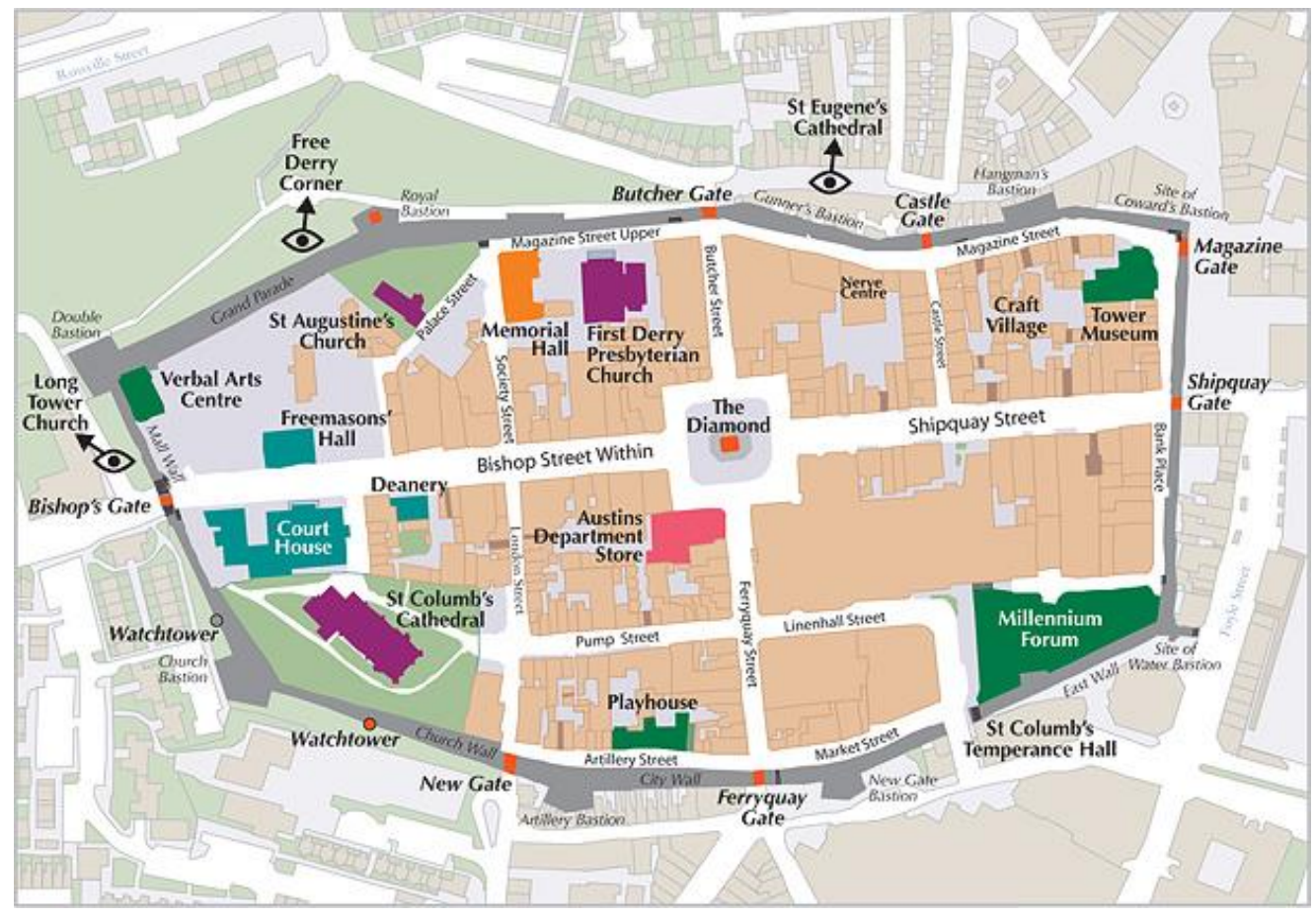

Figure 6: Detail of Walled City in Derry/Londonderry. Source: Derry City Council

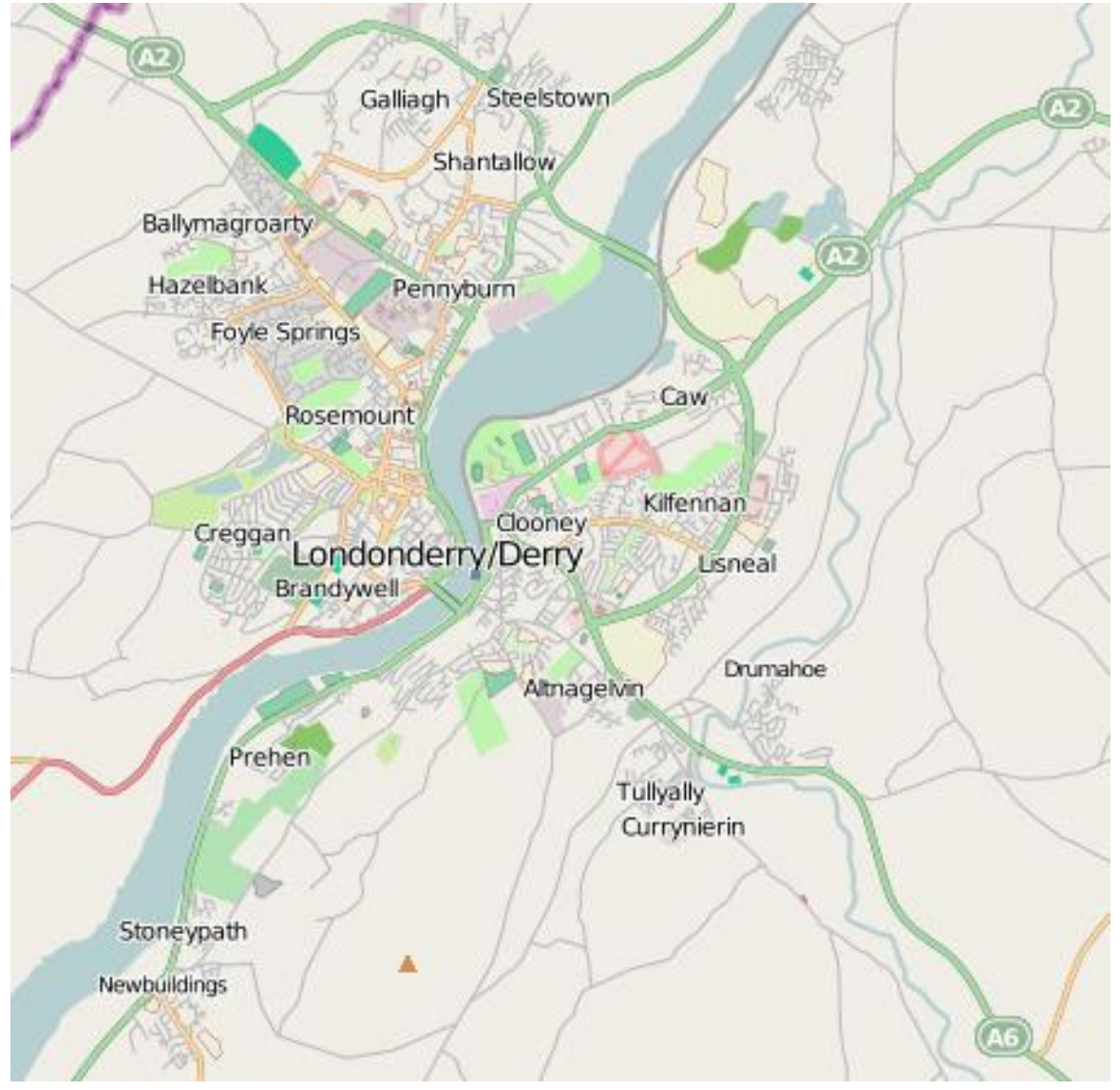

Figure 7: Map of Derry/Londonderry. Source: Open Street Map 
City of Culture where art, theatre, music and film exhibitions became the focal point for visitors throughout the year. The city saw record numbers of visitors throughout the yearlong celebration (NITB 2014). Though the city has fostered growth in tourism, it has not marginalized conflict sites. On the contrary, it has marketed them widely through Northern Irish visitor centers and on the internet. The city's effort is consistent with diversifying tourist offerings in the region as a whole. The city is looking to incorporate conflict sites into a wide array of tourist attractions. The work involved in this incorporation is complex. 


\section{CHAPTER 3}

\section{ANALYSIS OF NORTHERN IRISH CONFLICT SITES}

Showcasing sites of Northern Ireland's political heritage and the violence contained within it involves combing through the various presentations of narrative from official and local-folk perspectives. These are more complex than polar opposites. These perspectives inform and respond to one another as they generate the narratives presented to the public. The presentation of conflict sites as tourist attractions is approached differently according to the dominant narrative and place. This chapter examines how conflict sites developed as a solution to the problem of conflict and tourism coexisting within the same society by appropriating, repackaging, displaying and selling to the region's visitors. The analysis demonstrates the complexities of the relationship between the official and local-folk perspectives, their fluid nature through time and space, and their impact on the narratives presented within tourist attractions and on the process of tourism as a whole in Northern Ireland.

The terms conflict tourism and conflict sites grew out of my own struggle with the problems presented by dark tourism, dark sites and their supposed opposition to heritage tourism. Lennon and Foley create a binary distinction between dark sites and heritages sites, arguing that it "is a simple matter of chronological distance" (Bowman 2010: 190; Lennon 2000: 12). That is, in order for a site to be categorized as dark it must fall within "the memories of those still alive to validate them" (Lennon 2000: 12). A site passes 
from dark to heritage because the emotions attached to them pass with the final survivor. However, technological leaps in photography and communication prove that this is simply not true. Live streams of disaster and tragedy can be viewed from any computer screen, tablet, television or smartphone, anywhere on the globe, at any time, in real time. Photographic and video technologies do more than capture and instantly report the creation of dark sites; they extend living memory beyond those directly affected by an event. The memory and emotion no longer dies with the last survivor. Photographs, videos and audio clips preserve events, so they can be experienced and relived over and over and passed on to a new generation of viewers. In the digital age, reopening old wounds and rehashing previous wrongs is easier than ever. Despite the transformation of sites into tourist destinations, struggle, conflict, and political connotations linger.

That being the case, conflict sites do not pass on from one category (dark) to the next (heritage) because those who survived an event pass away. Conflict in an area is not a single event, instead it is a process that develops over time. Conflict encompasses many aspects of society and at times coalesces into memorable events that shape a society's progress and are established as a part of history. The individual players in conflict may change, but until a resolution is enacted, the conflict keeps its charge. Heritage and history, then, become problematical when categorizing sites. I use heritage as an interchangeable term for history because the terms are essentially one and the same. Traditionally, heritage is presented as highlights of a society's past, the 'good parts' of the dominant social group's history. However, I suggest that heritage encompasses all parts of a society's past, creating a tapestry shaded by all experiences, good and bad, of both the dominant and subaltern groups. Even though certain events of the past may not 
all be shining moments of glory or moral right-doing, those events are still a part of a group's heritage (Bowman 2009: 190). Conflict, then, becomes an integral part of a society's heritage. A conflict site is marketed as a heritage site, and there is a certain amount of somber reverence afforded to these sites.

The following sections examine site data gathered on two short ethnographic visits to Belfast and Derry/Londonderry in March 2009 and June/July 2013. These trips were characterized by a lot of movement to several places, like a tourist. I attempted to gain an understanding of the sites, first as a visitor on holiday, then as an anthropologist. The data is sorted by region, and then by dominate narrative. While I've previously stated that official and local-folk perspective are entwined processes, I will be separating these processes for the sake of analysis. To that end, a pattern emerged between Belfast and Derry/Londonderry. As the analysis of Belfast unfolds, a spectrum of narratives and perspectives will be presented, beginning with Officializing Appropriation of locally produced sites. Many of the sites appropriated by tourism began as local solutions to conflict. These activities have been partially officialized in a bureaucratic attempt at conflict resolution, tourism becomes involved through this. However sites are prepared by and continually informed by local creativity. The next narrative discussed, Official Production, examines the official perspective in Belfast and how it is presented to the visiting public. Finally, Localizing Appropriation of officially produced sites shows the relationship between the local-folk and official perspectives at work.

At Derry/Londonderry the official perspective is not the same as in Belfast. The Catholic/nationalist majority city government has shifted the official narrative of the city 
away from the national narrative of Northern Ireland. Most conflict sites are Official Productions, however, many have been Locally Appropriated.

\section{$\underline{\text { Belfast }}$}

Sectarianism runs through every fiber of social life in Belfast. It affects where one shops, where one's children attend school, where one lives, where one works and what social events and gatherings one attends. Despite this separation, tour operators and visitors to the city inhabit space in a different manner for a limited period of time. Victor Turner's liminal period in a rite of passage describes "the liminars (the ritual subjects in this phase) are ambiguous, for they pass through a cultural realm that has few or none of the attributes of the past or coming state" (Turner 1978: 249). Visitors to conflict sites bend the socially imposed rules of segregation. Social norms are suspended while engaged in activities of tourism. Individuals who would normally be unwelcome in certain neighborhoods or communities are more likely to be allowed to pass through on touristic business. For example, our taxi tour guide, a Catholic, took us deep into the Protestant neighborhood of the Shankill where we spent most of the tour exploring the various murals on display.

\section{Mural Painting in Northern Ireland}

The murals of Belfast can be visited in a number of ways: bus tours, taxi tours and even walking tours are offered by various companies. My companion and I took a taxi tour of Belfast's murals because the private experience would allow me to ask more questions than a larger tour would have permitted. The tour guide introduced himself, making a point to note that he was Catholic before offering a short history of the sectarian 
struggle in Northern Ireland, specifically the Troubles. As the taxi neared the Shankill Road, our guide explained segregation in Belfast and how it contributed to the events of the Troubles. Once inside the Shankill neighborhood, the guide pointed out the Union flags and banners flying from the buildings, and the kerb paintings (figure 8) in union colors before moving on to our first mural.

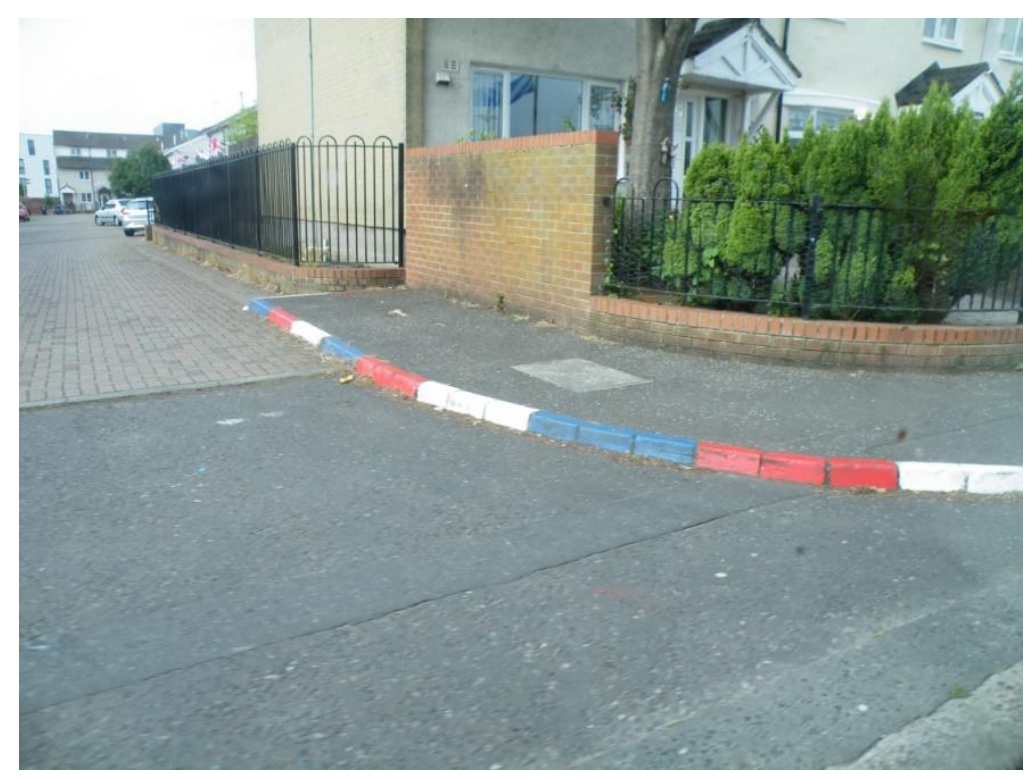

Figure 8: Union colored kerb painting in Shankill neighborhood

Mural painting in Northern Ireland has undergone many transformations throughout the $20^{\text {th }}$ and $21^{\text {st }}$ centuries. The practice has generally been associated as a vehicle of nationalist rhetoric outside of the Ulster region, but mural painting began as a unionist activity. Around the turn of the nineteenth century, the Orange Order, a unionist association, commissioned the painting of murals depicting historic scenes of King William III of Orange and his victory at the Battle of the Boyne on 12 July 1690 (figure 9). King Billy murals and others like it focus on past events or 'defining moments' in history. The mural depicts a battle ready William holding his sword aloft and seated 
upon a rearing white stallion in the middle of the Boyne River. Two orange flowers decorate the sides of the portrait on a black background with the date emblazed in red.

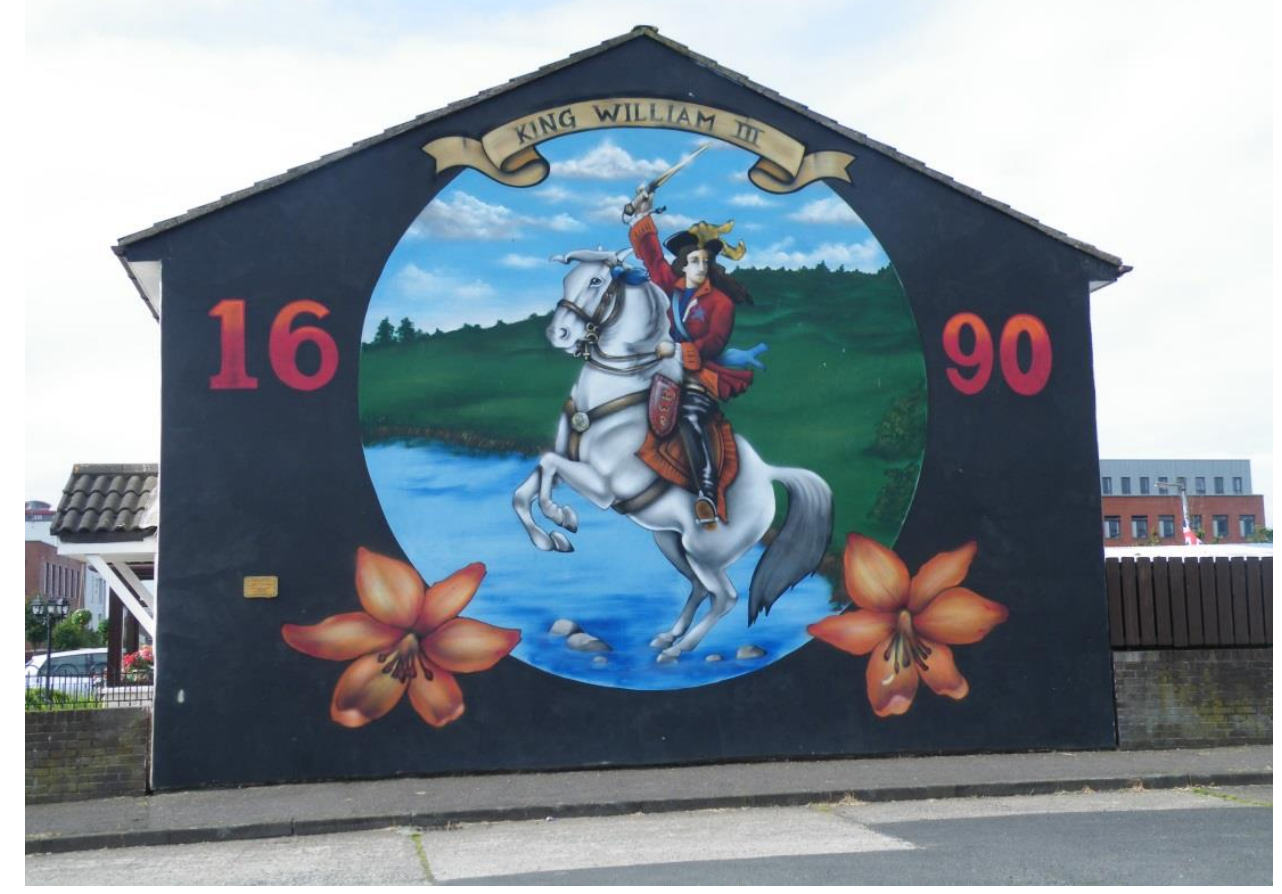

Figure 9: King William of Orange mural on Shankill Parade

At this mural, our tour guide explained the significance of the Battle of the Boyne and 12 July. Over a century after the Battle of Boyne, a Protestant organization formed to put down the rebellion of the United Irishmen. The Orange Order continued as an elite Protestant organization dedicated to union with Great Britain. It wasn't until the late nineteenth-century that the order gained popularity as a symbol of unionist beliefs (Hennessey 1997; Rolston 1991: 16). During the 12 July celebration, the Orange Order hosts parades and marches of Orangemen and lodge drum and fife and/or marching bands. Allen Feldman argues that these marches are a symbolic reinforcement of English sovereignty over the Irish (Feldman 1991: 28-30). The King Billy mural is a representation of Protestant heritage, a symbol of Protestant victory over Catholics. 
This tradition soon evolved as new themes to express unionist ideology were sought. For nearly sixty years unionist murals dominated the urban landscape, promoted official rhetoric, and ranged in theme from historical to political to humorous in nature.

Unionist mural painting declined in the mid to late 1960s. During this time the focus shifted to maintaining the "King Billy" murals. Until the 1970s, nationalists saw mural painting as a strictly unionist practice. The creation of the peace lines, walls separating violence prone neighborhoods, gave Catholic and nationalist communities blank canvases upon which to paint their feelings. What began as graffiti became fullfledged mural painting in the late 1970s when the prisoners at Long Kesh prison embarked upon the Blanket Protest. By the end of the protests, which culminated into the Hunger Strikes, both republican and loyalist paramilitary organizations adopted the practice and began to paint murals as territorial markers laden with their organization's ideology. Later still, political parties, such as Sinn Féin, began sponsoring murals that touched on the party's political points of view, while women's groups used murals to show their support and solidarity with other women in conflict zones (Rolston 1991). Mural painting began as part of the official narrative in Northern Ireland. The dominant group presented their history upon the walls as displays of dominance. The practice of mural painting was appropriated by nationalist groups, and the dialogue between the official and local-folk perspectives was literally painted on the walls. Unionist-identifying individuals dominated the governance of Northern Ireland at all levels and would continue to do so until the Good Friday Agreement established a new devolution of government under the Northern Ireland Assembly (1999) and Northern Ireland Executive. Until this time, the official and local-folk perspectives paralleled the 
dialogue between unionist and nationalist groups. As Nationalists made significant gains in the governing of the region, the official perspective shifted from solely unionist rhetoric to an emphasis on power sharing and neutrally worded narratives. In response to these shifts, the local-folk perspective changed. No longer representing one group's narrative, the local-folk split into many different perspectives encompassing nationalist and unionist sentiments expressed by those not involved in the governing of the region. Murals continued as an expression of the local-folk narratives, and while their content has always been diverse, the overall theme centered on the conflict. The murals are testaments of violence and bloody conflict. Each new brush stroke changes the original mural and creates it anew whether it be restoration, vandalism or a complete repainting; all add a new angle to the painted conversation. No matter how long a mural remains upon the wall, the conflict embedded within their images reminds the community of violence, both physical and structural, rooted within the structures of the society of Northern Ireland.

\section{Officializing Appropriation: Murals and Memorials}

The Shankill neighborhood is a maze of streets with a mixture of single family homes, duplexes and apartment blocks situated around small community greens. Many of the murals painted in the Shankill face these green spaces and the streets that border them. One such mural depicts Cuchulainn. He is both a nationalist and unionist symbol. A hero in the Ulster cycle of Irish mythology, Cuchulainn was an Ulsterman who defended Ulster against his enemy Queen Medb of Connacht (Connell 2008: 227). In unionist depictions, Cuchulainn is a strong and fit young man, usually at the peak of his physical condition. In the Shankill mural (figure 10) Cuchulainn stands under the Ulster 
Banner. A scroll to the right of the scene proclaims; "Here we stand, Here we Remain. We simply want to take our God ordained place as indigenous Ulster people. Understanding and living our calling we assume our identity without shame, retaliation, or indignation against those who have caused harm to our past...tried to castrate our culture our identity and our place on this island".

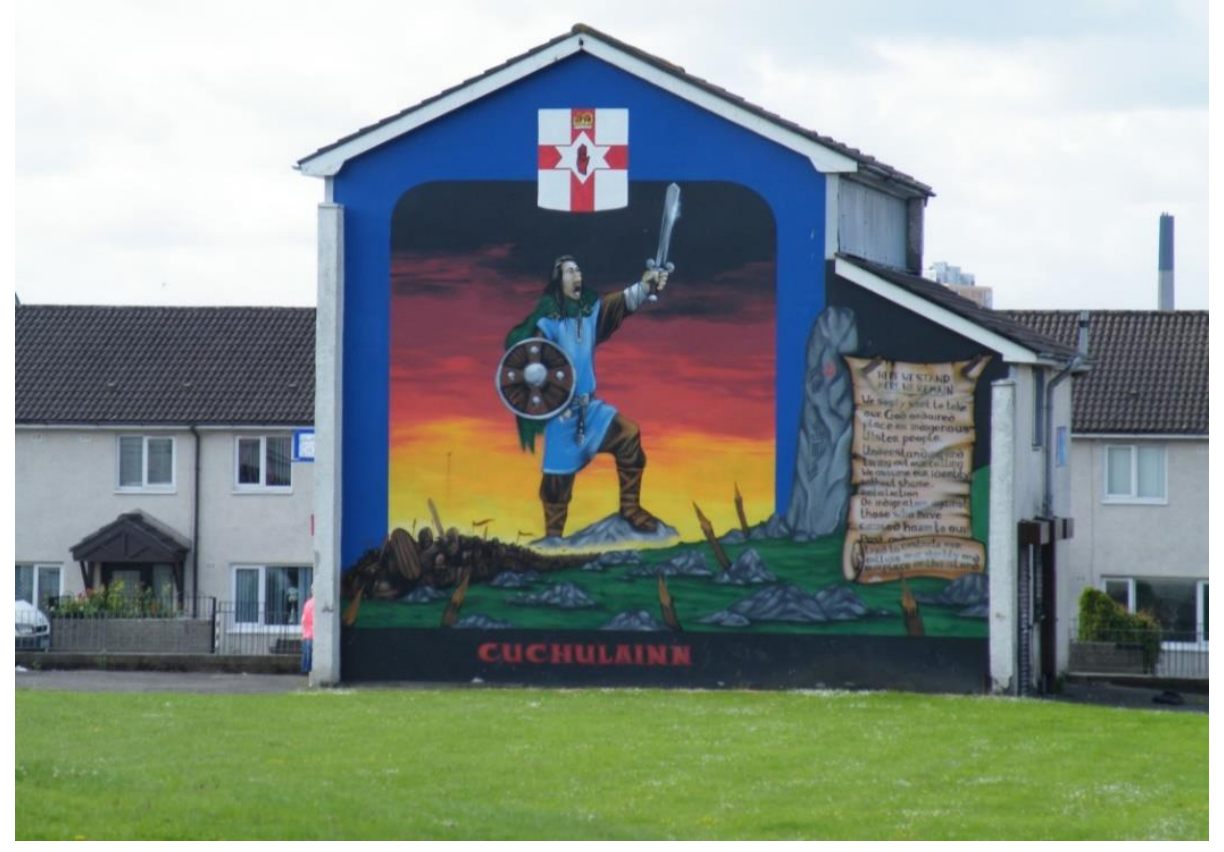

Figure 10: Cuchulainn on the Lower Shankill Road

While unionists use the symbol of Cuchulainn to reaffirm their claim to Ulster, for nationalists Cuchulainn is a symbol of sacrifice for the defense of Ireland. Nationalist murals of Cuchulainn depict his dying moments as a reminder to nationalists that many heroes have died for Ireland. One such mural from Drumarg Park, Armagh, displays the dying Cuchulainn (figure 11) surrounded by other nationalist symbols of Ireland: the Gaelic harp, a flaming sword and the whole island of Ireland. 


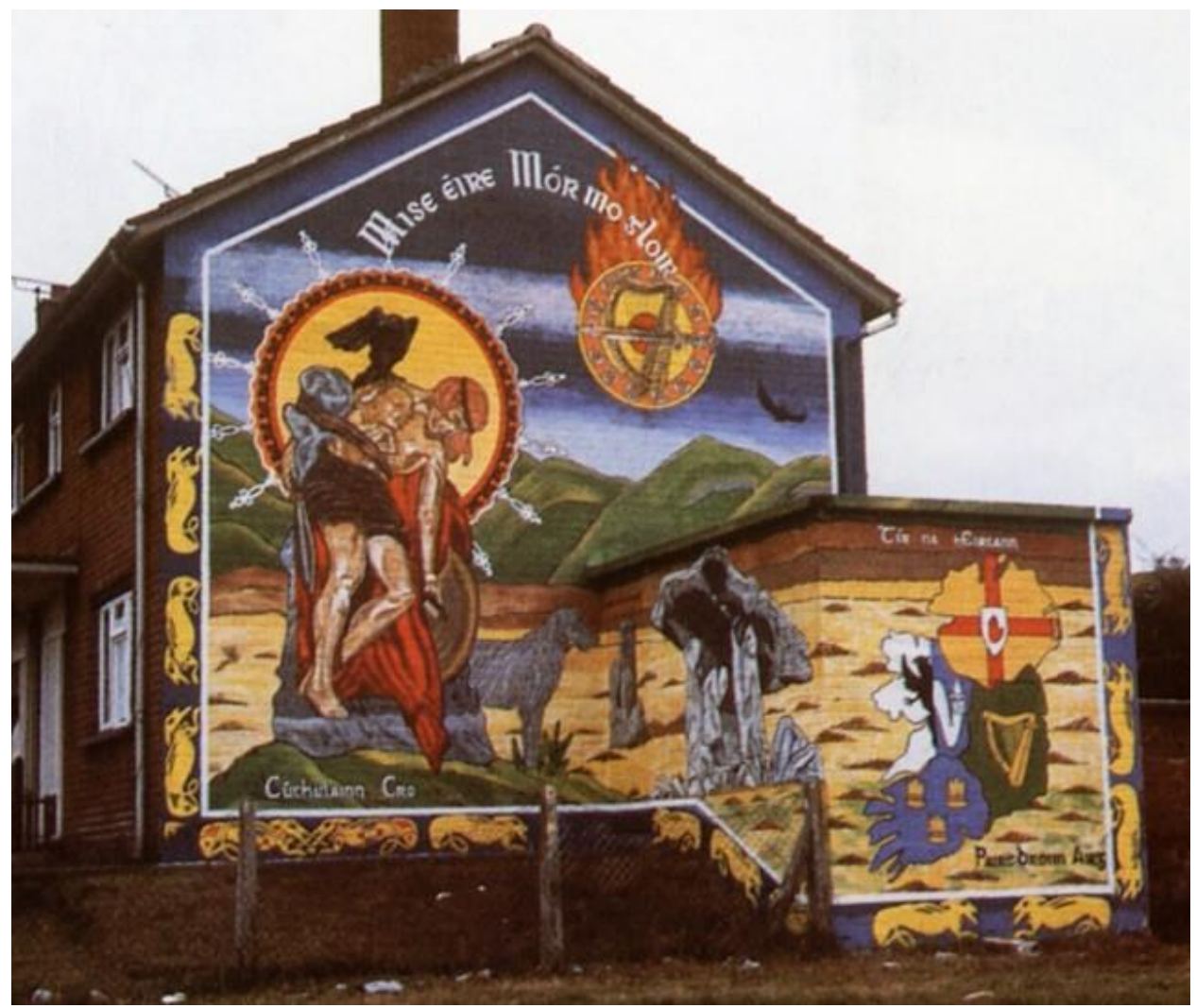

Figure 11: Nationalist Cuchuliann mural near Drumarg Park. Source: CAIN Archive

As discussed in chapter 1, this depiction of Ireland as a historically whole nation is inaccurate. The island was divided by kingdoms and clans who were often at war with each other. The historical inaccuracy does not invalidate nationalist ideology or identity. The Irish identity is a recent construct, one created by indigenous peoples of the island in opposition to English colonization. It is subject to constant reevaluation. Collective nationalist ideologies and identities became an important part of society after the American and French revolutions. They were a response to crisis as resulting from the changing socio-political climate (James 1999: 134). Irish identity may share some key components, but differs from one individual to the next. There is no one definition of Irish identity, instead it is a multifaceted, complex construct that, as we have seen, 
encompasses both nationalist and unionist ideology. Cuchuliann is not the only figure of myth depicted in murals of the Shankill.

The mural of "The Red Hand of Ulster" is located on a house near the Lower Shankill Cuchulainn and is a graphic depiction of the myth behind the flag of Ulster (figure 12).

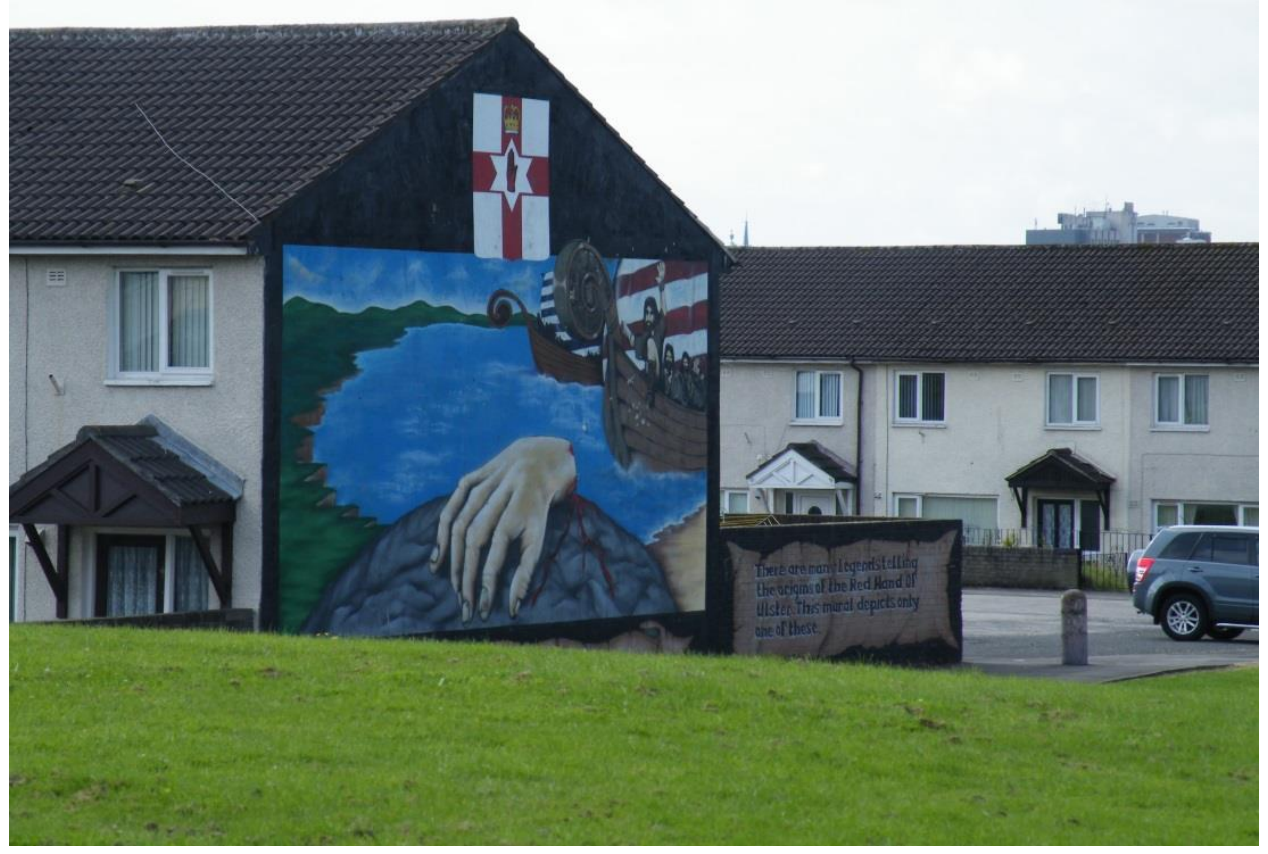

Figure 12: The Red Hand of Ulster in the Lower Shankill

The mural displays the Ulster Banner in the top center of the painting with the origin story styled on a scrap of parchment below. Two contenders to the throne of the kingdom of Ulster agreed upon a boat race. Whoever's hand was first to touch the shore of Ulster would be named king. When one of the contestants saw he was going to lose the race, he cut off his right hand and flung it towards shore. It landed on top of a rock 
and he was declared winner of the race and King of Ulster. The Red Hand is a prominent feature on the Ulster Banner. The flag of Ulster is a historically contested object.

The diversity of flags flown in the region is another example of the dialectic between the official and local-folk perspectives. The Union flag (figure 13) is currently the official flag of Northern Ireland. Sometimes, St Patrick's Saltire (figure 14) is used to distinguish Northern Ireland from the other regions of the United Kingdom. However,

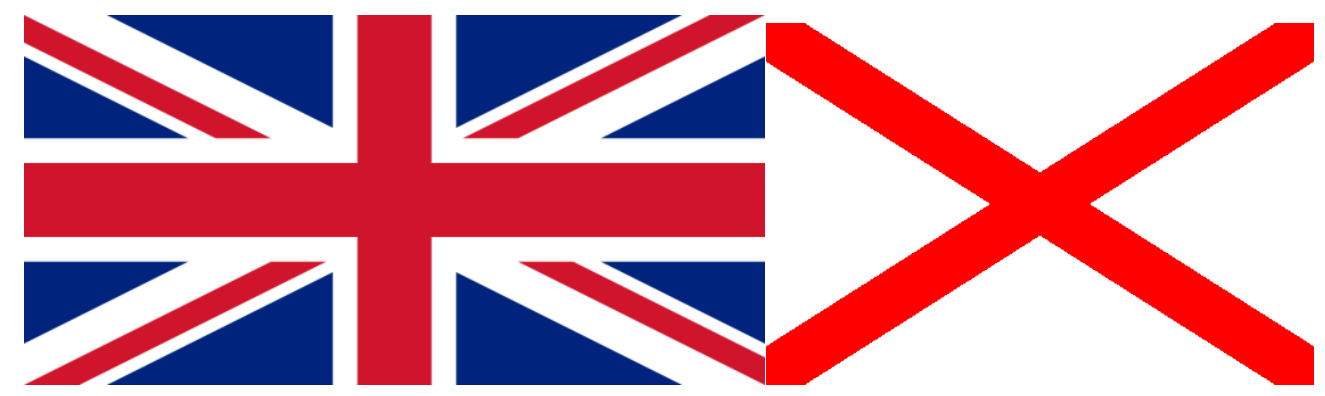

Figure 13 (left) Union Flag and Figure 14 (right) St Patrick's Saltire

the provincial flag of Ulster and the Ulster banner are still popular amongst citizens of the region. The provincial flag of Ulster (figure 15) depicts the red hand escutcheon centered over a golden field featuring a red cross. This version of the flag is a neutral symbol that is found at historic sites and sold in gift shops and souvenir stands around Northern Ireland. The Ulster Banner (figure 16) was the flag of Northern Ireland from 1953 to 1972. The red hand is rendered inside of a six sided star which represents the six counties of Ulster that make up Northern Ireland. The star is topped with a crown, representing loyalty to England. The English red cross on a white background lies behind the hand and crown. This flag is often flown in Protestant neighborhoods. The likelihood of seeing one rises during marching season and around 12 July. 


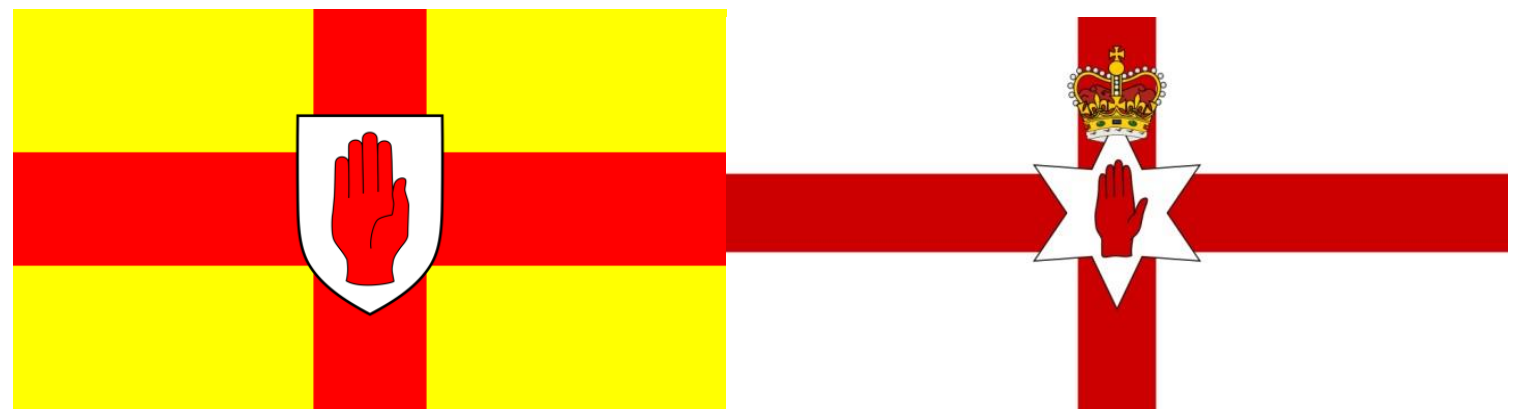

Figure 15 (left) Provincial flag of Ulster and Figure 16 (right) Ulster Banner

The Ulster Banner still has a place amongst the Union flags and banners in Protestant towns and neighborhoods. Private citizens and shopkeepers fly the Ulster banner from their awnings despite being retired as an official representation. The Ulster Banner and the Union flag are depicted in many Protestant murals covering all types of subject matter. The use of flags or flag-likenesses plays a role in territory marking, like kerb paintings. They are symbols of loyalty to the British union, Ulster and in some cases paramilitary organizations. In murals (figure 17) they remind the viewer from whose perspective the mural was painted and whose territory they are occupying. In the "Sniper" mural, the Union flag and the Ulster Banner are prominently displayed at the viewer's eye level on the bottom half of the mural. In this particular mural, the flags are the symbols of the paramilitary organizations, Ulster Defence Union and Ulster Defence Association that claim and protect the territory of the Shankill.

The provincial flag of Ulster is also used as a representation of the region despite having no official sanction. It is sold to tourists in gift shops in Northern Ireland but also has an international presence. Ireland enthusiasts in the United States can purchase the provincial Ulster flag in many Irish themed shops and at Irish festivals hosted around the 


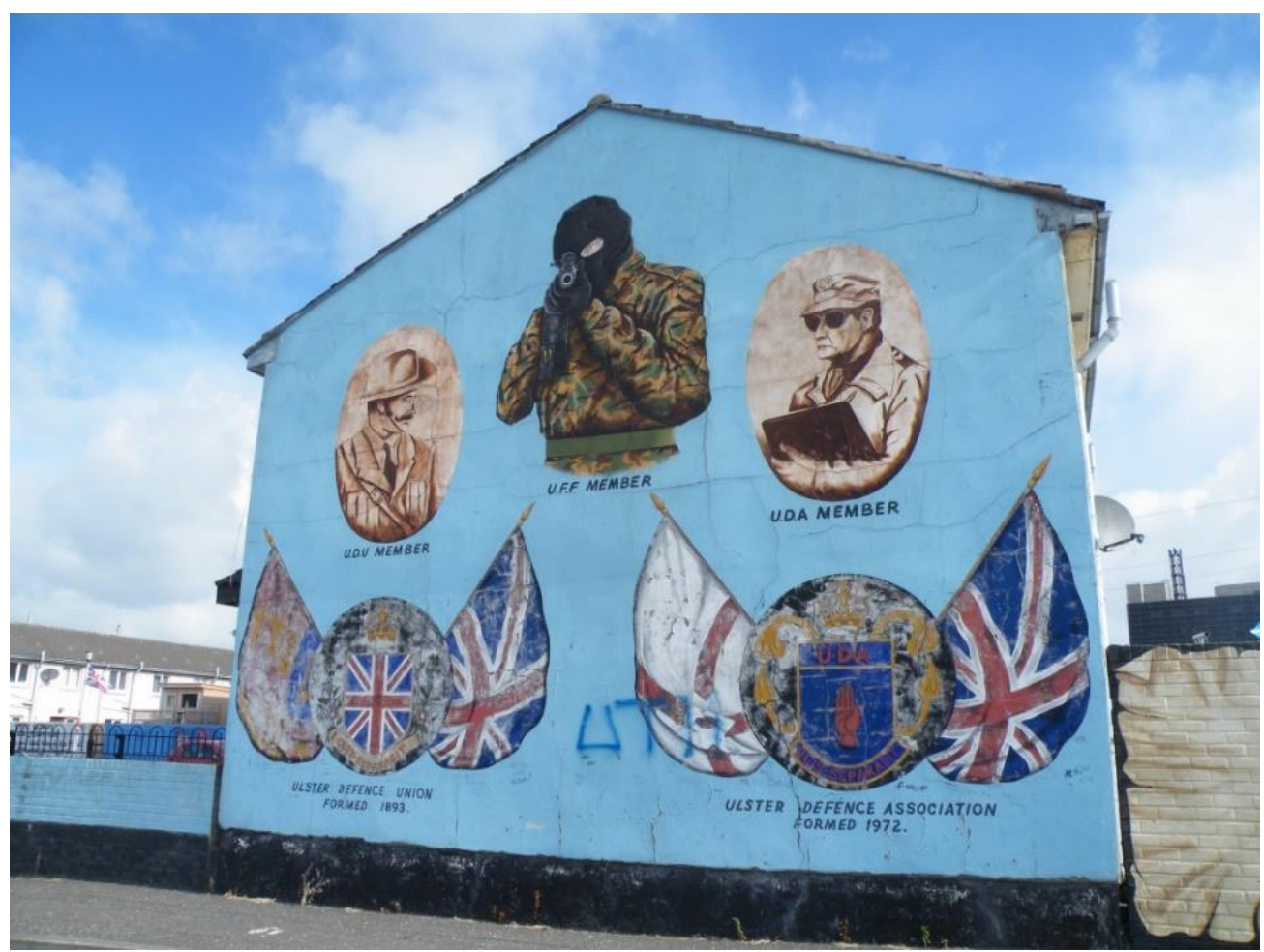

Figure 17: 'Sniper' mural on Lower Shankill Road

country. The flag is marketed simply as the Ulster flag. This marketing of the provincial flag of Ulster, along with the inclusion of the retired Ulster Banner on some unionist murals like the one pictured above, complicates an outsider's understanding of Northern Ireland and the complexities of the region's society. It also shows how diverse the official and local-folk perspectives can be.

The murals and memorials are like micro-interface zones that facilitate the mediation of conflict, tourism and the everyday activities of the local populace. Heritage, conflict, and tourism are bound together in their representations of culture and society and the lines between them become less distinct. As neighborhood murals become a part of the tourist landscape, the dialogue between mural and viewer takes on a new aspect. Outsiders viewing the murals do not understand the contents in the same way as local viewers. When viewed on a tour, the guide tries to impart the murals' messages to the 
foreign visitor using a combination of historical narrative and symbolic description. The murals remain politically charged objects but are transformed into something more through the lens of the tourist gaze.

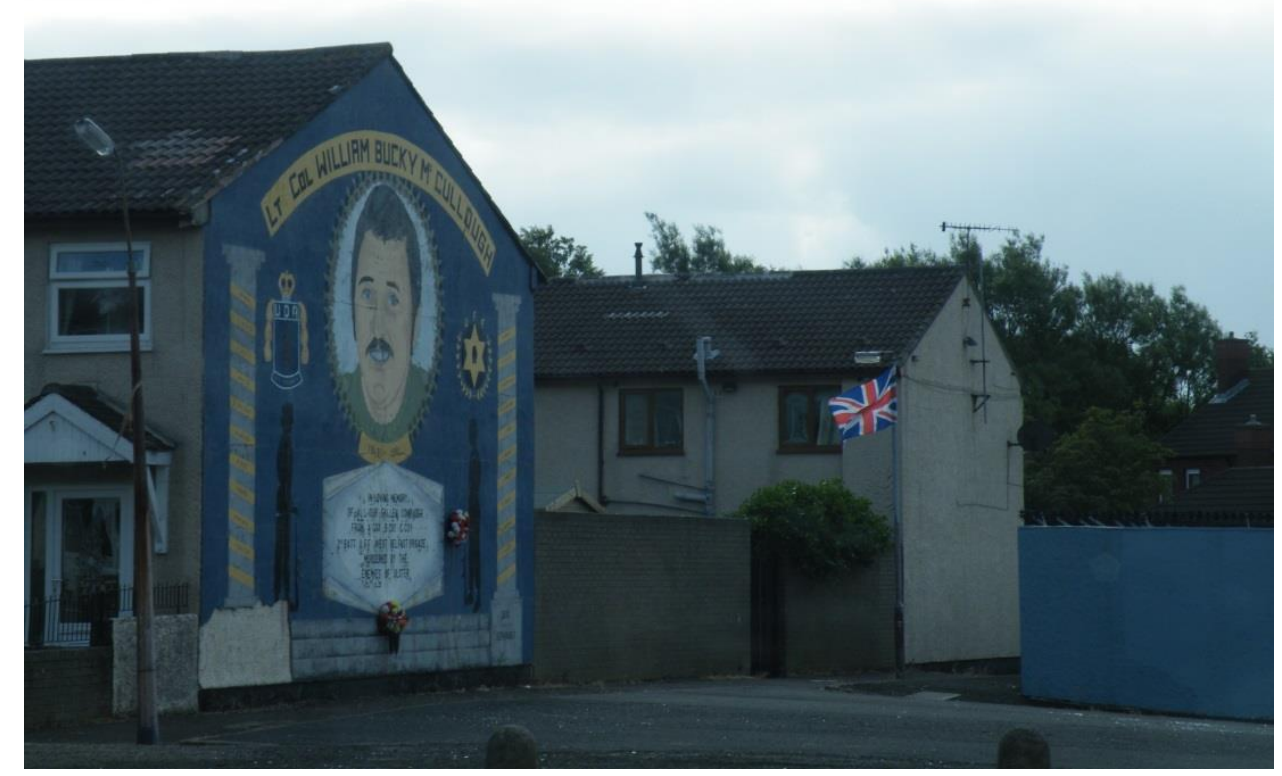

Figure 18: McCullough mural as seen from Denmark Street

A nearby memorial mural on Denmark Street is dedicated to Lieutenant Colonel William Bucky McCullough, a ranking member of the UDA (figure 18). The mural painted mostly in hues of blue, gold and grey has the likeness of McCullough surrounded by two pillars wrapped in gold ribbon. On the pillars, the names of other members of the UDA and the Ulster Freedom Fighters (UFF) who had been killed during the conflict are displayed. The bottoms of the pillars proclaim "Always Remembered" and "Quis Separabit" meaning "Who will separate [us]?", the UDA motto. Two paramilitary troopers stand watch under the UDA and UFF crests with a scroll between them declaring 
"In loving memory of all our fallen comrades, from A Coy, B Coy, C Coy $2^{\text {nd }}$ Batt UFF West Belfast Brigade, murdered by the enemies of Ulster” (figure 19).

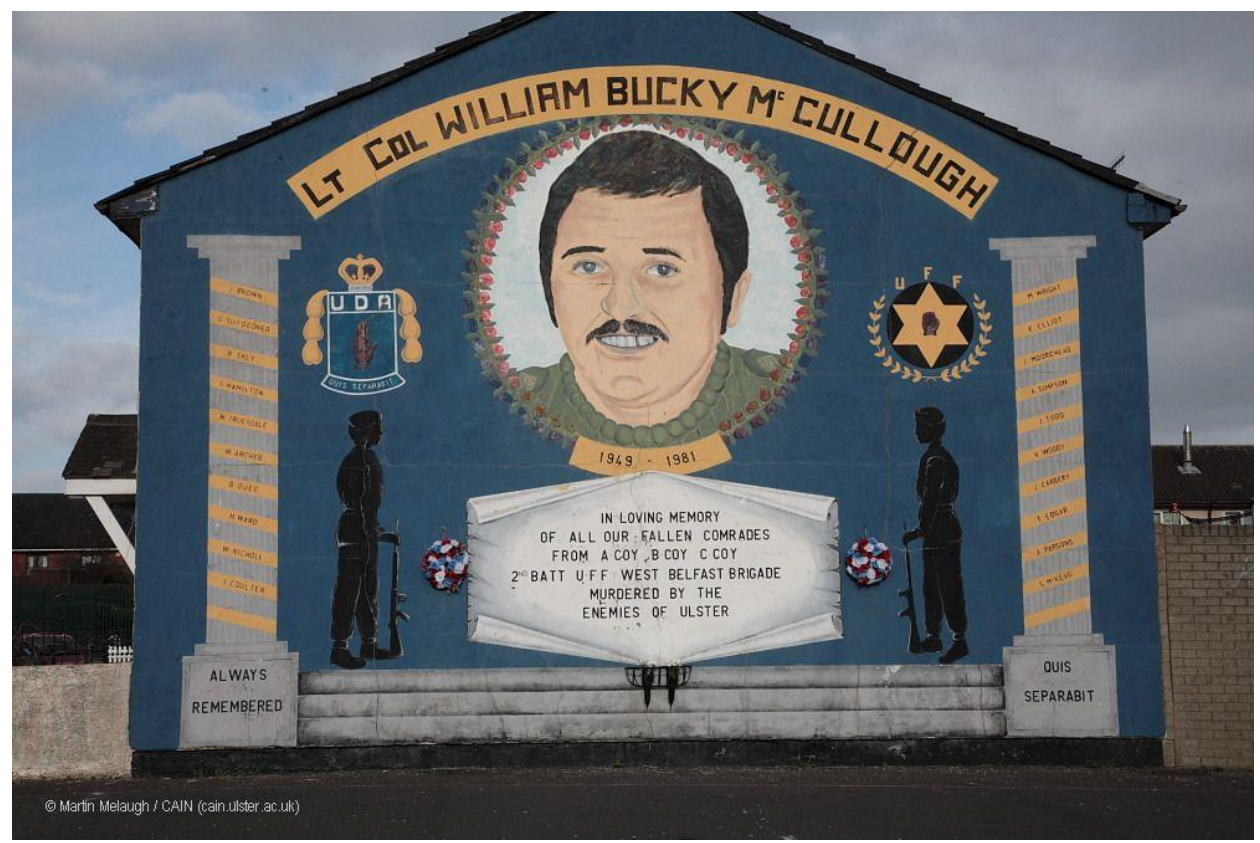

Figure 19: McCullough mural front view. Source: CAIN Archive

McCullough is considered a hero and was elevated to martyr status after his shooting death at the hands of the republican group, Irish National Liberation Army (INLA). These sites have become entangled within everyday life. They are not solely on display for the benefit of tourists. The memorial murals that dot the residential landscapes of Belfast and Derry are constant reminders of the past deeds, past lives and past events that form a portion of the chronology of the Troubles. These facets of the past are only glimpsed by the tourist as they briefly visit these sites.

In the Catholic neighborhood of the Falls, the Bobby Sands memorial mural (figure 20) is painted on the side of Sinn Féin headquarters. The Bobby Sands mural is a popular tourist destination, one we visited on a Belfast bus tour in 2009, and again in a taxi tour in 2013. While the bus tour guide gave a brief history of who Bobby Sands was 
and why he was so important, the bus paused on the Falls Road so tourists could get an angled shot of the mural from the comfort of their seats.

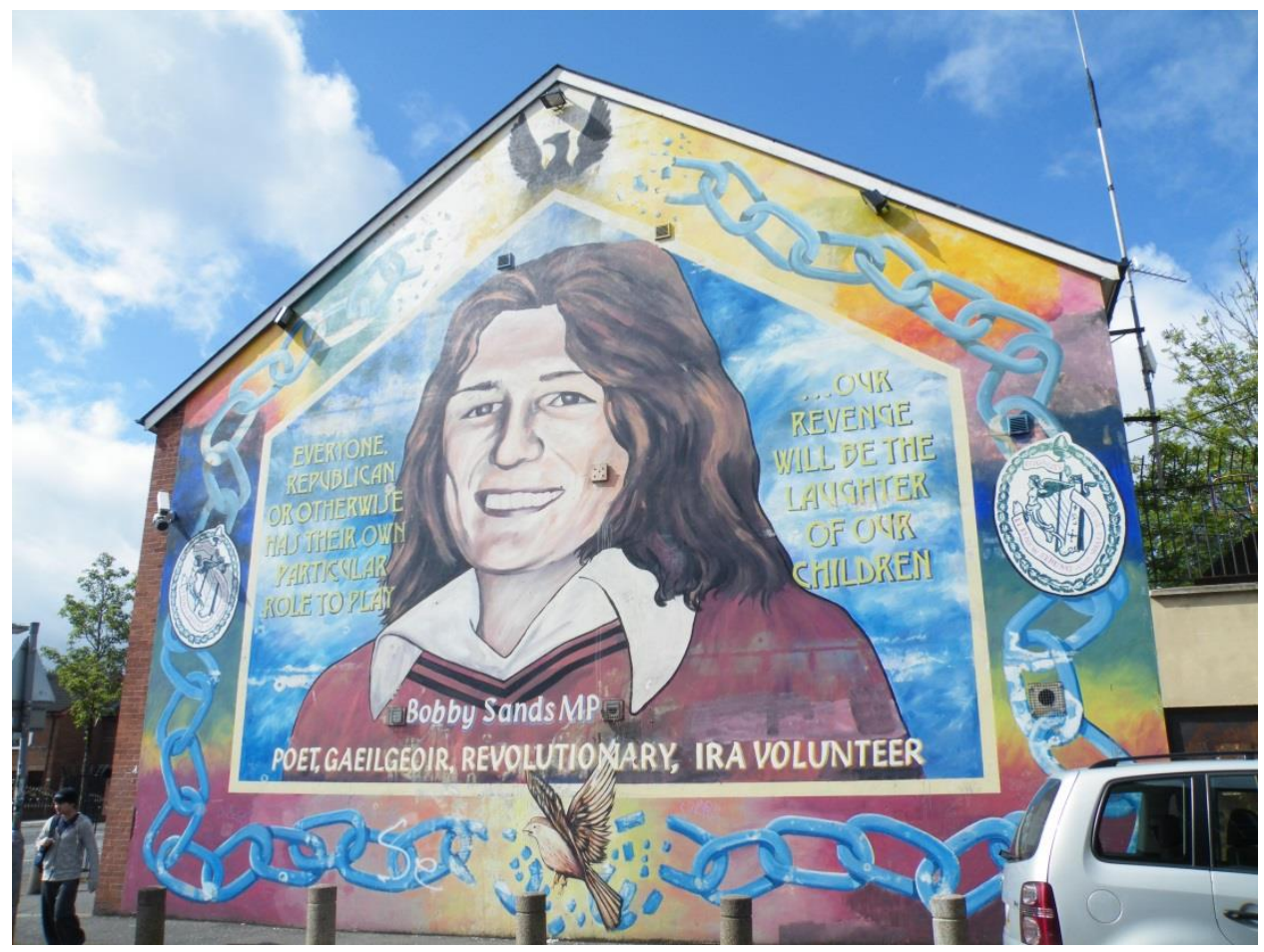

Figure 20: Bobby Sands nural on side of Sinn Féin Headquarters

In contrast, the taxi tour guide parked on Sevastapol Street and allowed us to get out and stand before the mural as he spoke of Bobby Sands, his imprisonment in Long Kesh, election to Parliament, his leadership position in the prison, and his death during the 1981 Hunger Strike.

Sands became a symbol in the local-folk narrative of nationalist heroism, as a man willing to give the ultimate sacrifice for the cause. He is treated as a martyr, as were the other men who died as a part of the Hunger Strike 1981.

In Catholic working class neighborhoods throughout Northern Ireland, extended families lived near one another. Close ties were kept among families, with sons living just a few streets away from their mother's home. Familial bond is important in the 
representation of the Hunger Strike in republican imagery. The focus on suffering is not limited to the striker's, but also to that of his mother. "Sand's mother's sorrow...allegorically represents the suffering of the country inasmuch as the country is represented as a mother" (Aretxaga 1997: 110). The suffering mothers of republican martyrs have been popular subjects of nationalist murals from the 1980s onward. The mother represents the entire nation of Ireland and the family left behind by the martyred individual. Furthermore, Familial bonds kept these communities tightly knit during the Troubles and explains the care taken to maintain many of the memorial gardens and murals in the Falls and Clonard neighborhoods.

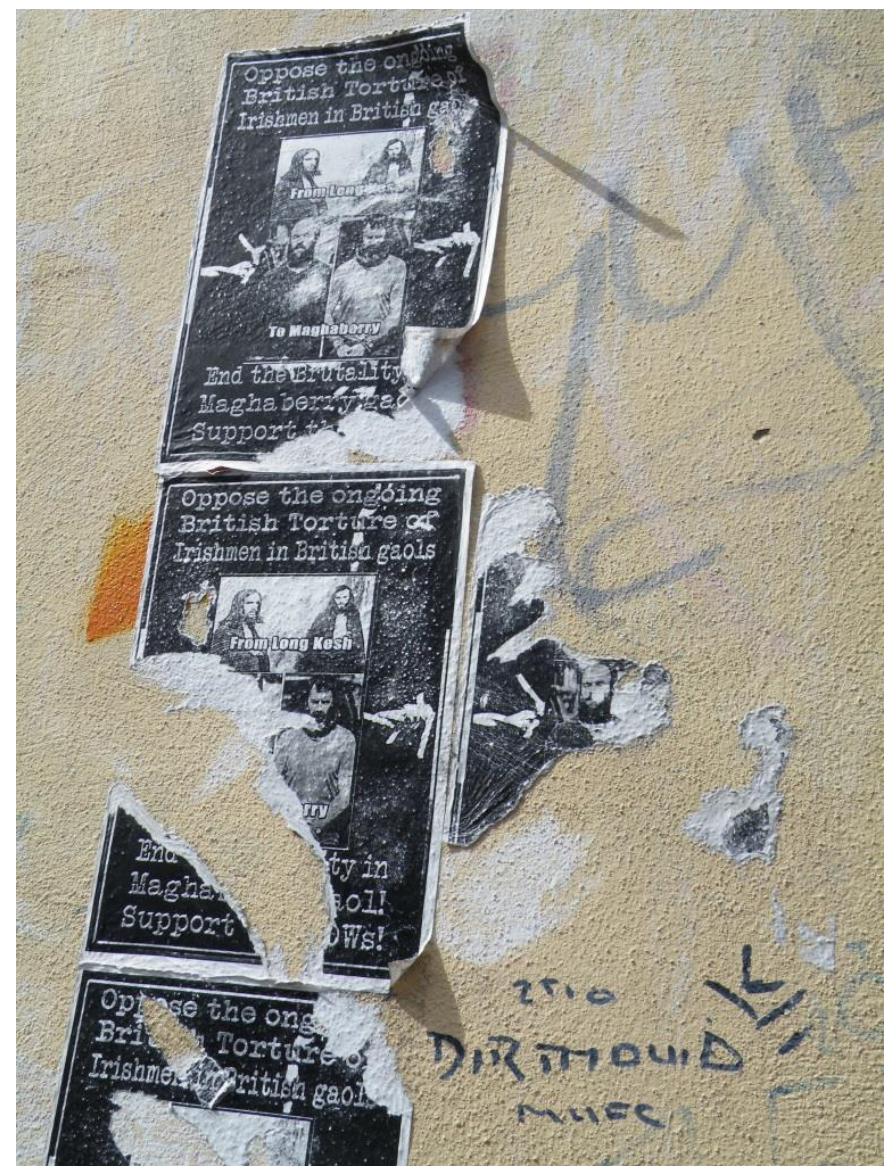

Figure 21: Flyers decrying abuse in Maghaberry gaol. 
While our guide was talking, I noticed a grouping of torn flyers (figure 21) affixed to a nearby wall. The black and white papers compared the current treatment of nationalist prisoners in Maghaberry gaol to that of those in Long Kesh in the late 1970s80s. The flyers were an example of the recent and ongoing public outcry against the treatment of imprisoned nationalists that were scattered around Catholic and nationalist neighborhoods and even occasionally encroached into neutral zones like Belfast City Centre. The flyers posted on the wall of Sinn Féin headquarters are a reminder to the tourist that they are visiting a living site. These sites were not created with tourism in mind, instead they are local responses to conflict that have become a part of the tourist landscape. They are a part of the continuing, contradictory dialogue on historical narrative, where there is a desire to both sanitize history and display history in all its detail.

Preservation of history's details is found at the local-folk level of conflict site creation, specifically in memorials. In 1969, nationalists and Catholics across Northern Ireland participated in a number of protests. These protests sparked attacks from loyalist groups and devolved into four days of rioting, the most violent of which occurred in Belfast. During the riots, Cupar Way and Bombay Street were nearly destroyed. IRA association and the neighborhood's history of violent conflict with the surrounding Protestant areas made it a prime site for military occupation. Outposts and peace gate stations became flashpoints for violence. Skirmishes between the British army and paramilitary fighters often broke out at these places and the surrounding interface zone.

The Bombay Street or Clonard Martyrs memorial is one of many garden style memorials found in neighborhoods erected in the names of those who were killed in 
violent sectarian clashes. The garden is all brick and wrought iron and utilizes the back of the Cupar Way peace line. Images of the Clonard Martyrs line the wall.

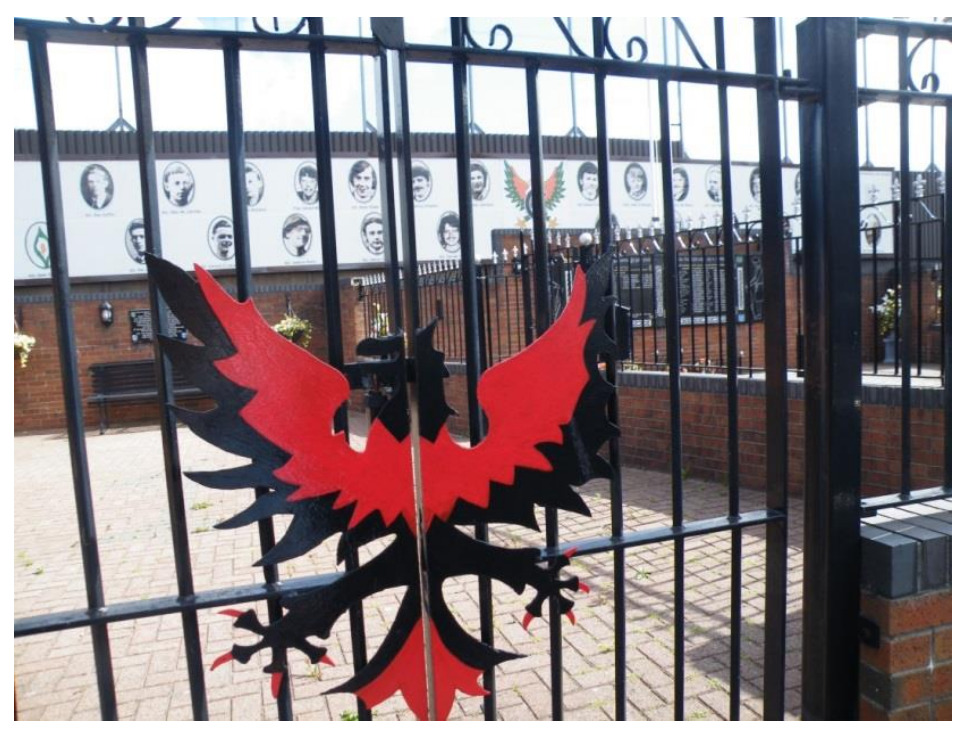

Figure 22: The entrance gate with the phoenix sculpture

The entrance to the memorial (figure 22) is adorned with a metal sculpture of a phoenix newly risen from the ashes. Inside, the garden is divided into three sections where plaques (figure 23) dedicated to those "who have resisted and still resist occupation" and those who have lost their lives during the conflict. Places for floral $\operatorname{arrangements}^{25}$ and benches are placed throughout the memorial site. The placement of the benches, many of them sitting across from black plaques inscribed with names, invite visitors to sit and quietly remember the fallen members of the Falls-Clonard community. A large printed mural (figure 24) dominates the right side of the garden with images of the Bombay Street bombings, and a dedication to the junior IRA member Gerald McAuley.

\footnotetext{
${ }^{25}$ At the time of our visit floral arrangements were frequently tended and refreshed with new flowers.
} 


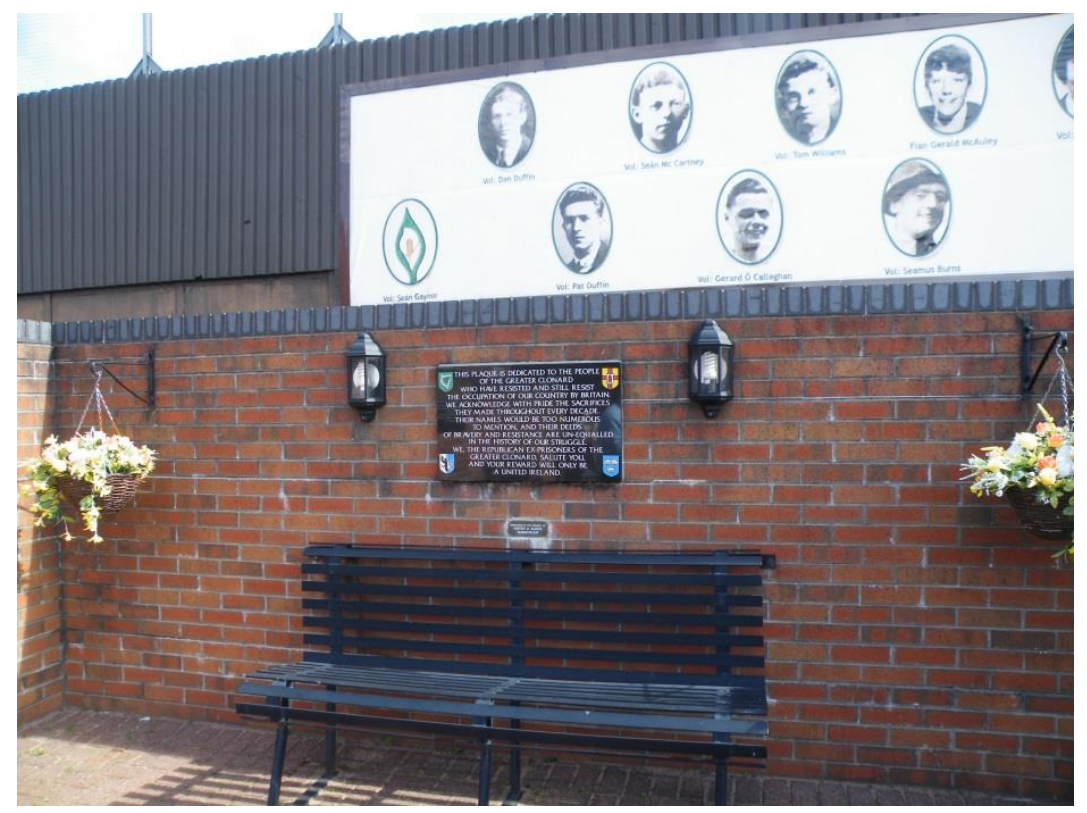

Figure 23: A plaque in the left most section of the garden

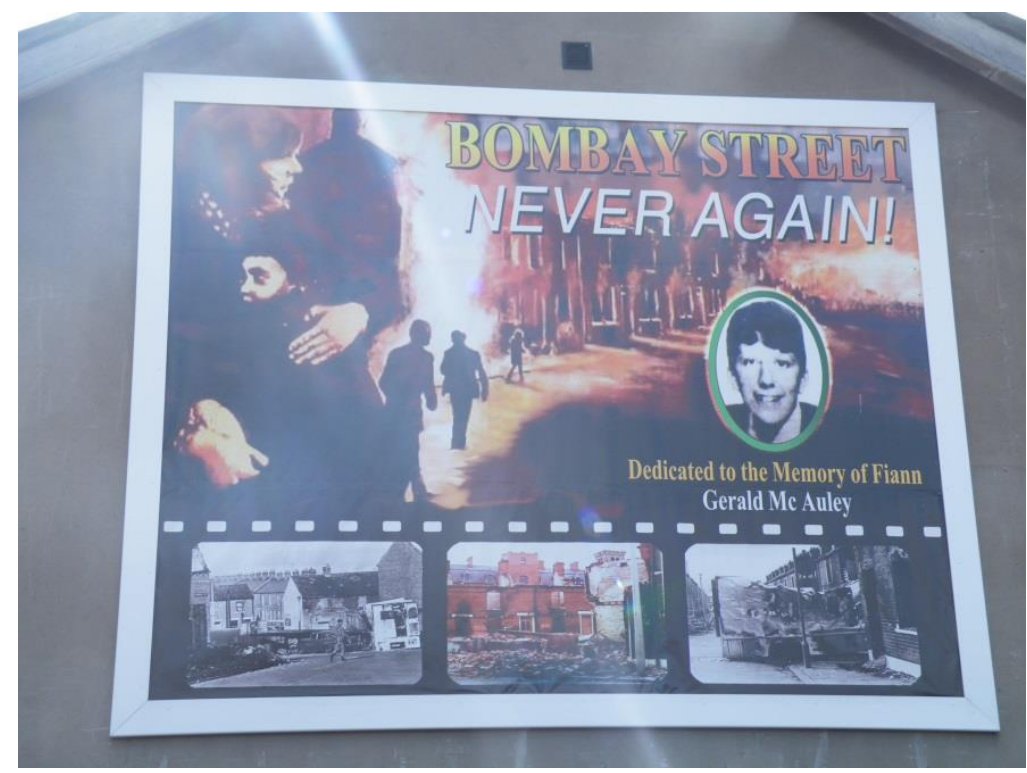

Figure 24: Bombay street mural situated on a house gable overlooking the Clonard Martyrs Memorial Garden

The memorial and its images stand in contrast to the loyalist memorial murals

found in the Shankill. While loyalist murals are vaguely dedicated to those who had died in the conflict with an image of one or two victims, the Clonard garden overwhelms the visitor with faces and names. Like the Vietnam War memorial in Washington DC, 
Clonard garden demands respect and reverence from the visitor and is not just a tourist site. In fact its status as a tourist site is secondary to its function as a site of remembrance for the Clonard community. Locally produced sites that are appropriated by the official perspective for tourist consumption are not the only types of sites found within Belfast. Another type of site, officially produced tourist attractions, are also abundant.

\section{Official Production: The Ulster Museum and Titanic Belfast}

The Ulster Museum at Queens University houses a permanent exhibit in the History Zone dedicated to The Troubles, entitled "Plantation to Power-sharing: The Troubles". The museum was closed and completely renovated in 2009 , at which time the Troubles exhibit was installed.

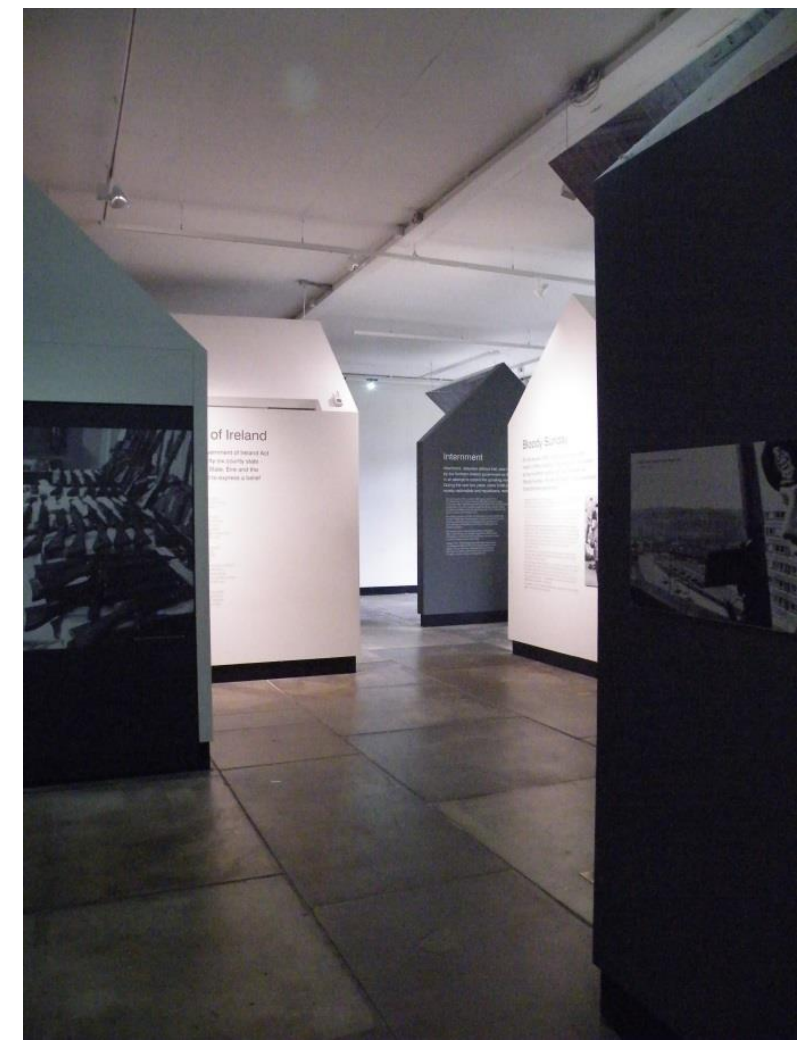

Figure 25 
The exhibit consists of a maze of stark white walls artistically displayed as the gables of homes similar to those found in the many urban residential areas of Belfast (figure 25). Black and white images, text and film media are displayed on the walls as if they are murals. The exhibit imitates daily life and space in the urban areas of Northern Ireland. Political statements are quite literally and fittingly written on the walls. At the entrance, an image of a traffic cop carrying a blood soaked child greets the visitor (figure 26).

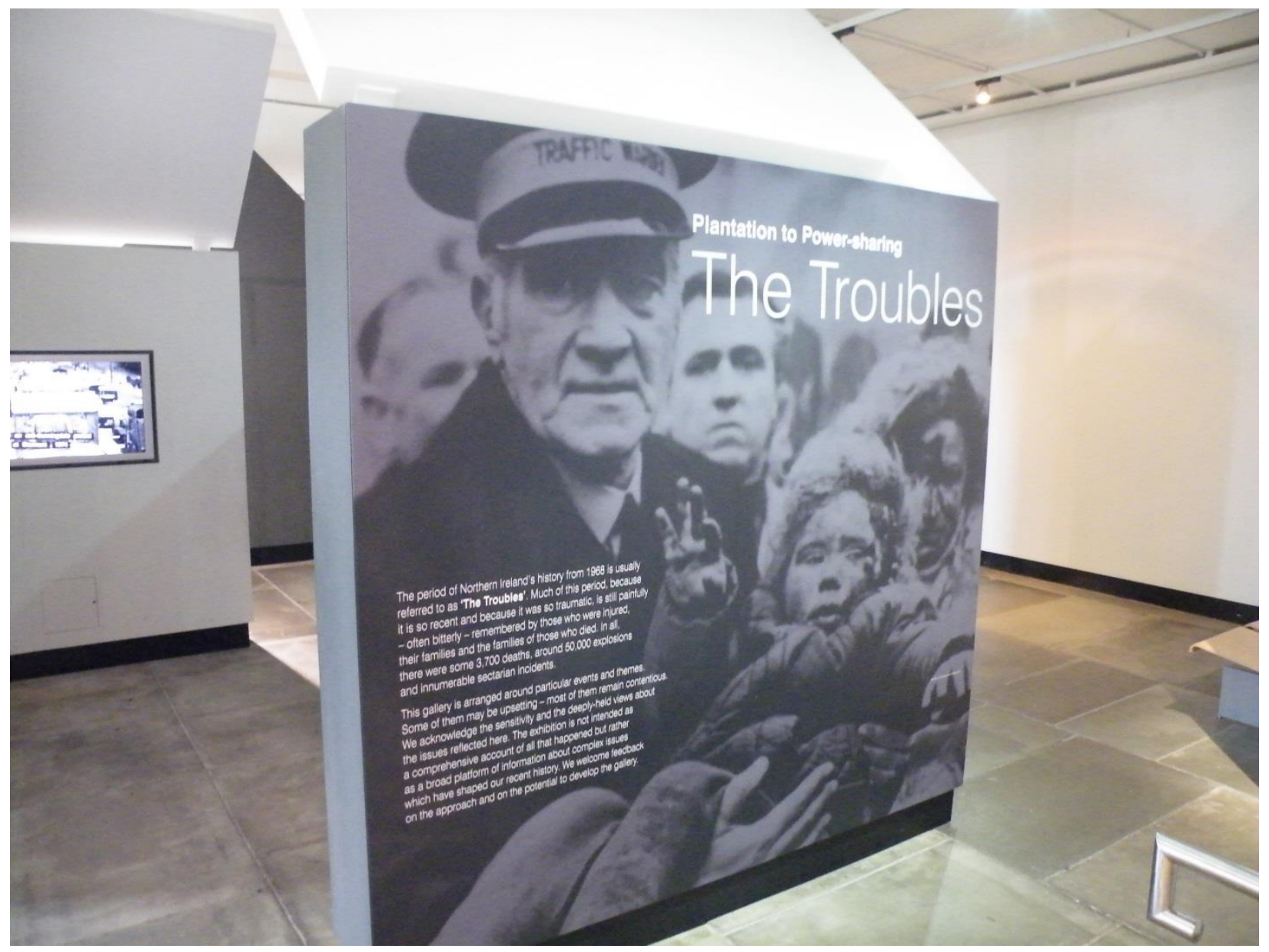

Figure 26

The text introduces the visitor to the gallery and claims "the exhibition is not intended as a comprehensive account of all that happened but rather as a broad platform 
of information about complex issues which have shaped our recent history" (Plantation 2013). As the visitor progresses through the room, they are confronted with images and descriptions of violent clashes (figure 27). Some images are blown up larger than the rest and placed near text walls or by themselves for the visitor to contemplate (figure 28).

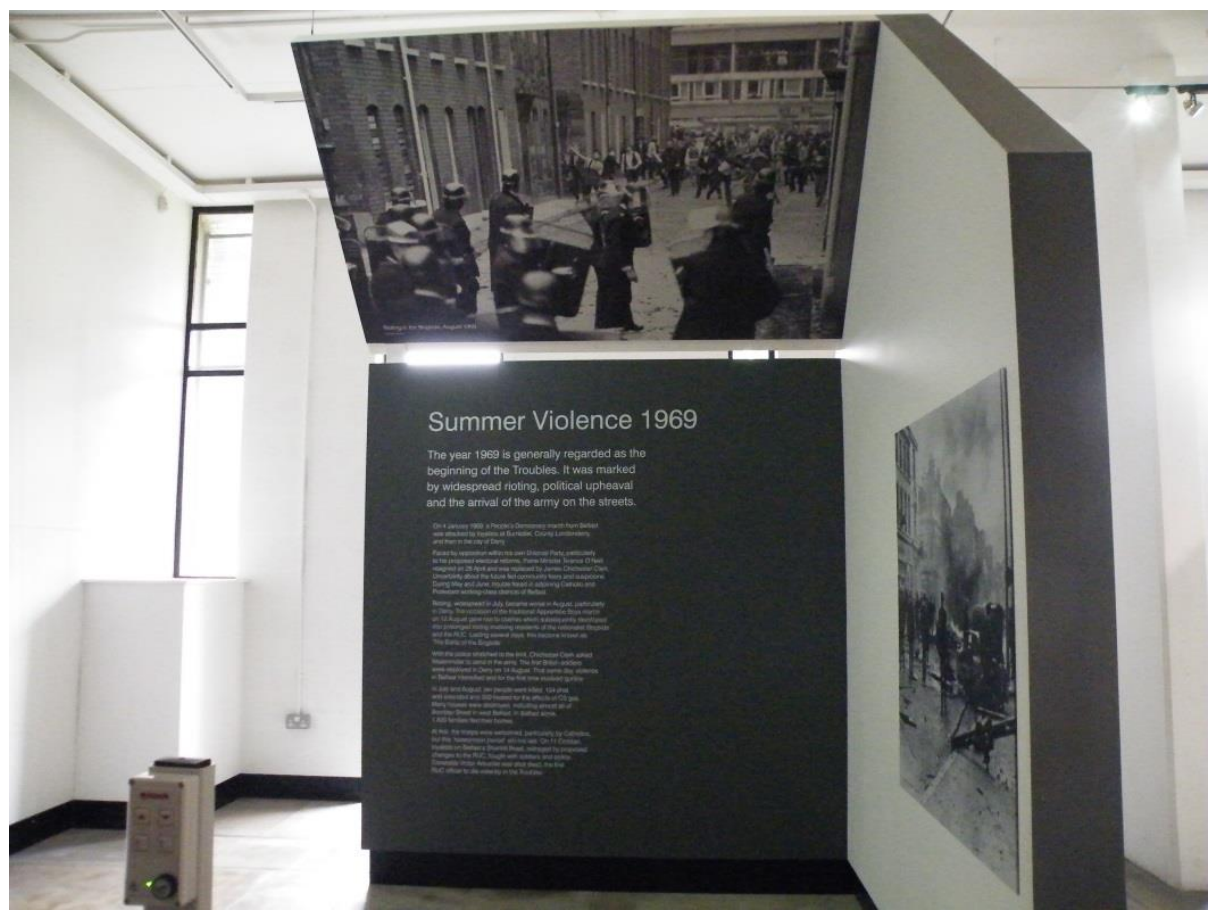

Figure 27

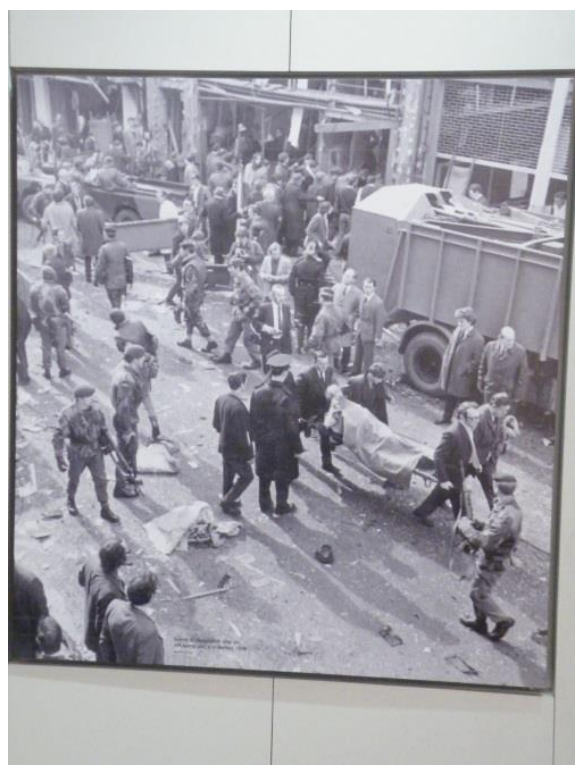

Figure 28 
The text walls outline a historical timeline with an overview of the Civil Rights Movement beginning in late 1968 and moves to a brief synopsis of the summer of 1969 , covering the riots of that year's marching season and the arrival of the British Army. A Troubles timeline concisely maps out the major events for the visitor (figure 29). The next area examines Internment, prisons and the events of Bloody Sunday. Beyond these walls in the back corner of the exhibit is a small sitting area walled off from the rest of the exhibit where the visitor may sit and reflect upon the exhibit or in some cases sit and quiet their emotions (figure 30).

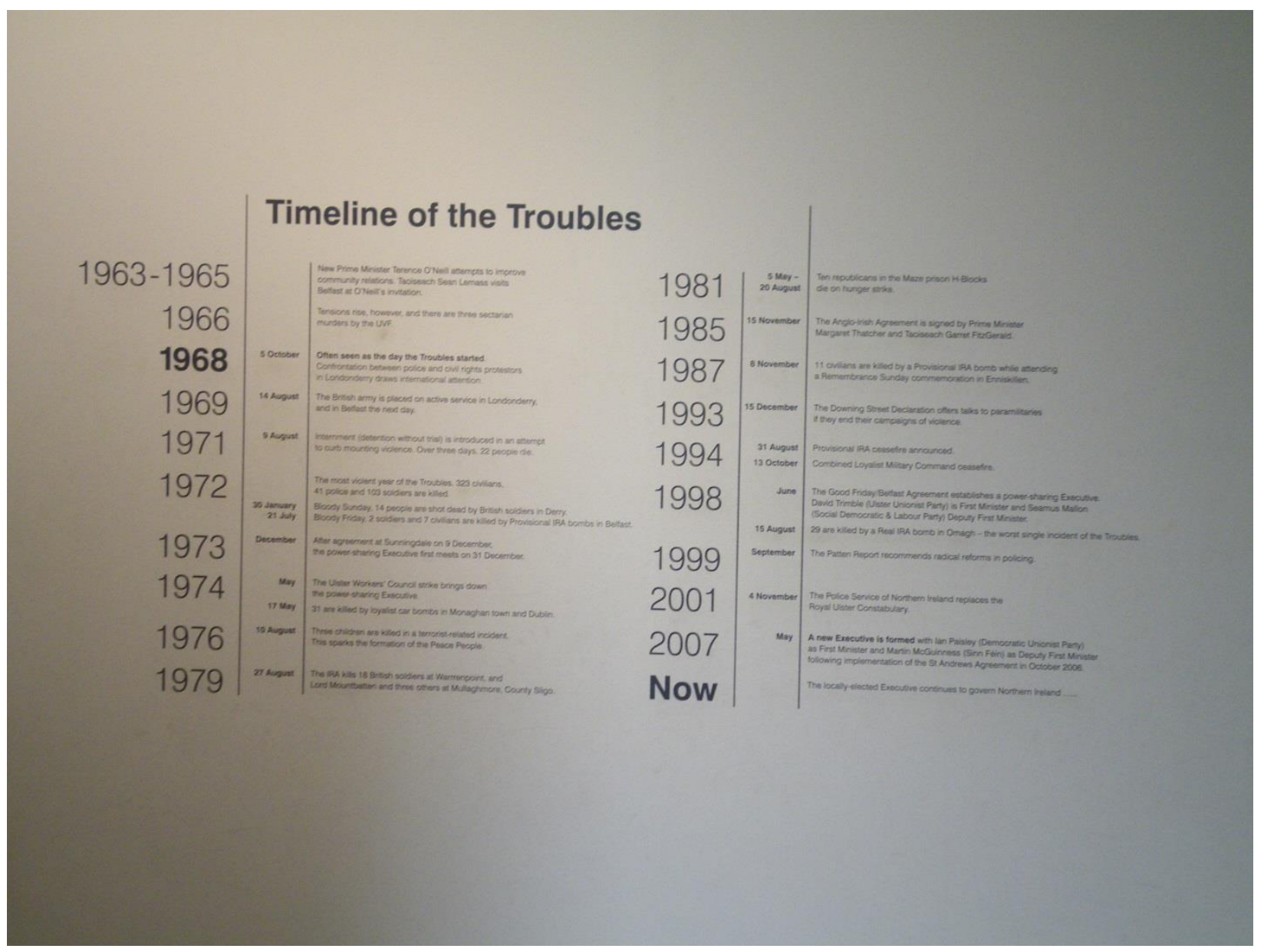

Figure 29 


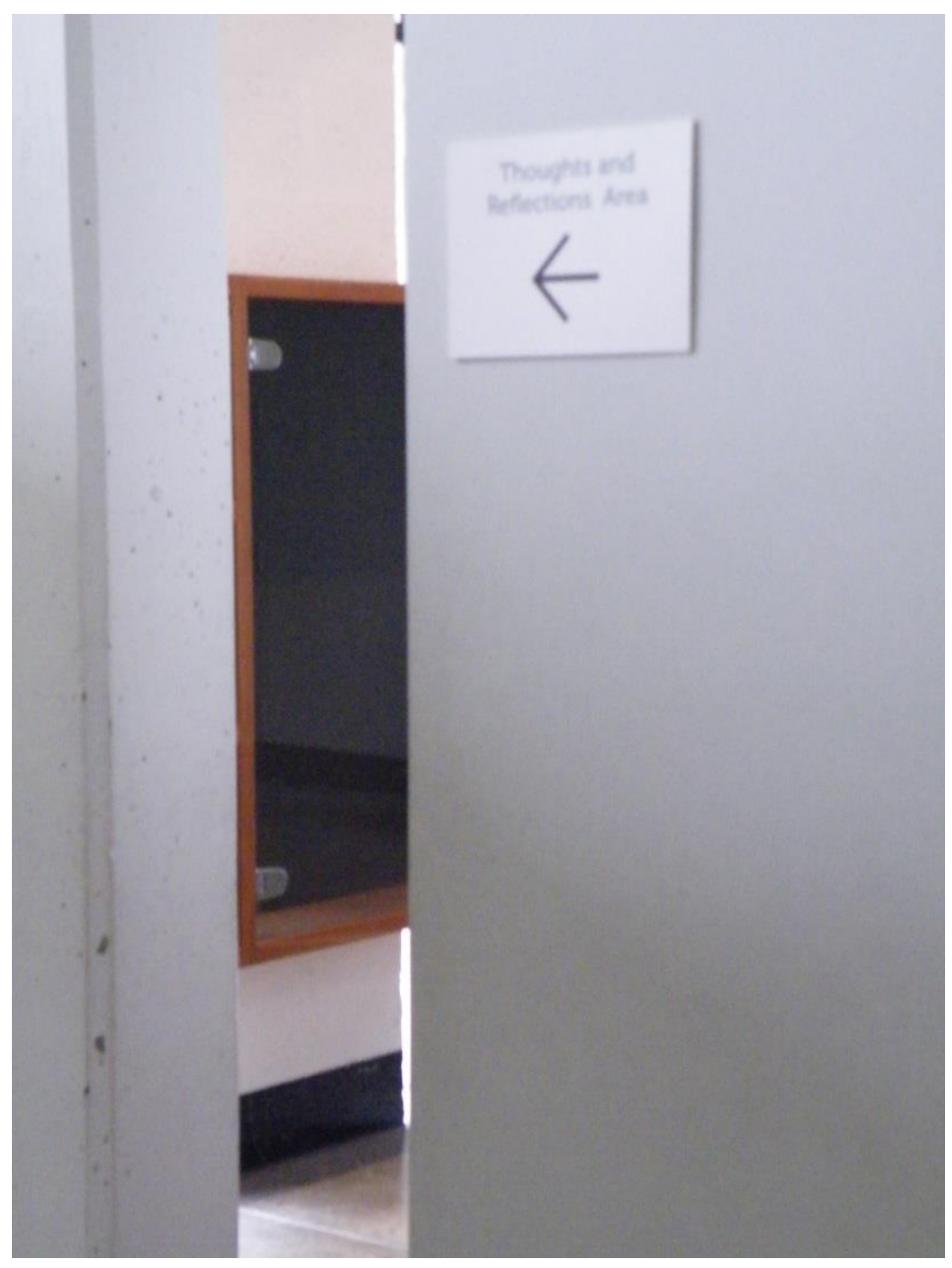

Figure 30

On a bookshelf within the sitting area are opinion surveys on which visitors can leave comments about the exhibit. Near these surveys is a small book collection covering topics on the peace process in Northern Ireland and the aftermath of the Troubles.

Outside of this area, the exhibit's text walls crowd around with displays of the 1981 Hunger Strike, Peace Campaign and bombing campaigns with special attention given to Omagh $1998^{26}$. The bombing was RIRA's rejection of the Good Friday agreement

\footnotetext{
${ }^{26}$ The RIRA bombing of the County Tyrone town which killed 29 people and injured 200 more in August of that year.
} 
signed months before. The incident drew international attention and has been the last major outbreak of violence to date.

If one follows the museum's map and starts in the Welcome Zone, The Troubles room is the first section of the History Zone the visitor will encounter. The Troubles exhibit exits into the next gallery in the History Zone dedicated to the Plantation period from the $16^{\text {th }}$ century to modern Ireland. The visitor transitions from a world of blacks, whites and grays into a startling barrage of color. The stark and austere reality of the Troubles exhibit is shattered by bright red text plaques and cases filled with artefacts. As the visitor progresses through the museum from History Zone to Science Zone to Art Zone, the experience of the Troubles exhibit becomes lost within the experiences of all the other collections within the museum: history from the Plantations of the $16^{\text {th }}$ century back to Middle Stone Age 10,000 years ago, displays of extant and extinct native animals, fossils, dinosaurs, geological displays, pottery and china from various time periods and places, an art collection of "over 12,000 works comprising drawings, paintings, sculptures, glass, ceramics, silver, furniture, costume and textiles, covering the styles from the $17^{\text {th }}$ century until the present." (Ulster Museum website). By the time the visitor has completed the entire museum an estimated 3 to 4.5 hours later, the Troubles exhibit is pushed to the back of the visitor's mind.

In placing the Troubles room of the History Zone at the beginning of the tour, the British run and operated museum is acknowledging the conflict, in fact with great care and detail. However, the placement at the beginning of the tour, buries the profound statement of the silent white room in the rest of tour. It is hard to say whether this is 
intentional, but the placement at the beginning of the tour allows the rest of the museum and its exhibits to create distance between the viewer and the not-so distant past.

For analytical purposes, the Ulster Museum is a partial conflict site because of its exhibition of the Troubles and as a history museum. The museum displays an official version of events, and its presentation of that heritage suggests a neutral or as close to neutral approach as possible. However, the layout of the exhibits paired with the suggested walkthrough path alludes to the conflict in a structural way. The official narrative displayed within the museum is bound up in British dominance. Belfast continues to be a unionist majority region with a large localized population of nationalist minorities, tensions still threaten to transform into violence.

Like the Ulster Museum, Titanic Belfast is an official tourist attraction, created with visitors in mind. Titanic Belfast is one of the Signature Projects created by the NITB to revitalize tourism in Northern Ireland. The site was praised on several travel and tourist sites as a must see for visitors to Belfast. Local newspapers and online news sources have written glowing reviews for the exhibition center. So it was a surprise when our mural tour guide furiously explained the exhibit's failings as an inclusive historical source. On the way to Titanic Belfast from our last stop on the mural tour, our guide lambasted the exhibit as a misleading distortion of facts, and claimed that the Titanic was a "bastion of Unionism". He instructed me to look at the large collection of photographs of the 3000 men who built the Titanic. "In those crowds a scant 100 or so of those men were Catholics," he said, "but you won't be seeing that written on those info plaques." The museum has drawn similar criticism from the Catholic community as misrepresenting history. Visitors are led to believe that the community in Belfast was 
integrated and that work was not segregated or that Catholic Irish were not discriminated against. Even before setting foot inside Titanic Belfast, I had numerous questions of representation and historical manipulation. Inside, I found that the facts were represented, but the political and cultural struggle that has been a part of Belfast since the Ulster Plantation initiative was absent, except for a small area in the first gallery that explained the unrest of the early twentieth century.

Titanic Belfast is a true tourist site, built for touristic consumption. While I would classify it as a heritage site, Titanic Belfast is also a site in conflict. I believe it is an important site in view of how the local nationalist population views it as biased and deceptive in the omission of sectarian struggle and Catholic discrimination. The site is an example of how dominant social groups determine what aspects of history are displayed and how they are interpreted. While the spectacle of sight, sound and smell begins inside the atrium of the building where the visitor purchases their ticket and receives their 'passenger identity', the exhibition's starting point is on the fourth floor.

The tour begins in a room dressed in the style of a typical Belfast street in the early years of the twentieth century, with the information presented to visitors on walls designed as newspaper clippings. Images, illustrations and artifacts of everyday life vie for the visitor's attention. The sounds of a bustling street and busy linen factory are played over loud speakers to give the room added ambiance. If the visitor is taking the audio tour, each stop is carefully marked, so the visitor may stop and listen to the lilting narration of the exhibit. The visitor gradually proceeds from the fourth floor back to the ground floor progressing through nine galleries. The first gallery is, an overview of industrial Belfast in the late $19^{\text {th }}$ to early $20^{\text {th }}$ centuries. It hints at the conflict between 
nationalist and unionist fractions with a modest ceiling display of newspapers with a large header proclaiming; "Ireland demands Home Rule”. The gallery ends with the rise of the Harland and Wolff shipping company and seamlessly moves the visitor into gallery two by passage through the original ironwork $\mathrm{H} \& \mathrm{~W}$ gates (figure 31 ).

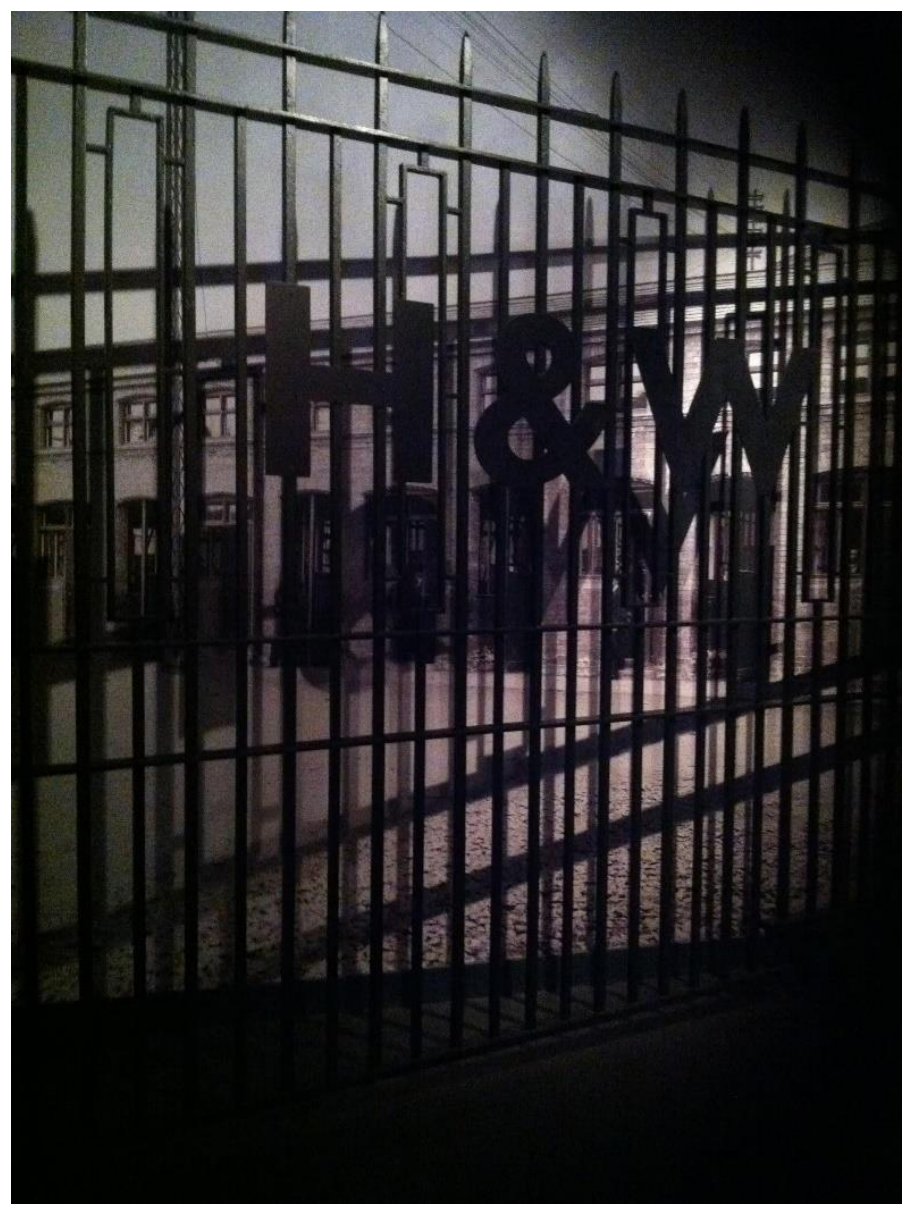

Figure 31

Gallery two focuses on the conception and building of the Olympic class ships with a dark ride. The dimly lit buggy ride moves the visitor through various audio-visual scenes of shipyard work. The buggy also functions as an elevator, moving the visitor to gallery three where attention shifts from a general look at life in industrial Belfast and to the Titanic. Galleries four, five and six displays the Titanic's launch and the events of its 
maiden voyage. Galleries seven and eight focuses the visitor's attention to the aftermath of the ship's sinking and how events are portrayed in works of literature and film.

Finally, gallery nine features a short documentary following Dr Robert Ballard and his team in their 1985 discovery of the Titanic wreckage. On the floor of the small theatre is a glass display beneath which lies a replica of the sunken Titanic. At the exit to the theatre, two workers stand with electronic devices that scan the visitors' passenger cards and let them know whether they "survived" the experience. It was at this kiosk that one of the contradictions of this site was brought to my attention. When asked whether the museum would display artifacts brought up from the wreckage, the young woman manning the booth explained that the museum wasn't interested in doing so because they wished to maintain a respectful tone. Something deemed incongruous with the display of objects from a tragedy.

I pondered the idea of respect for the dead and what I had seen in the museum. I consented that it had gaps in the history of life in Belfast, however the arrangement of the events of the Titanic's maiden voyage and its aftermath were well thought out with respect to those who had lost their lives. I was quite impressed with this, until I stepped into the gift shop. Once inside the shop, the idea of respect and care for the dignity of the passengers and crew of the Titanic vanished as I was confronted with rows and rows of kitschy souvenirs capitalizing on the Titanic phenomenon. While educational tools such as books and film were present, other items, pair of boxer shorts (figure 32) emblazoned with a black and white photograph of the Titanic or the Tubtanic (figure 33), a bath plug that floats eternally half sunk for your bath time enjoyment are just two of many items for sale that do not continue this tradition of care for the deceased's integrity. 


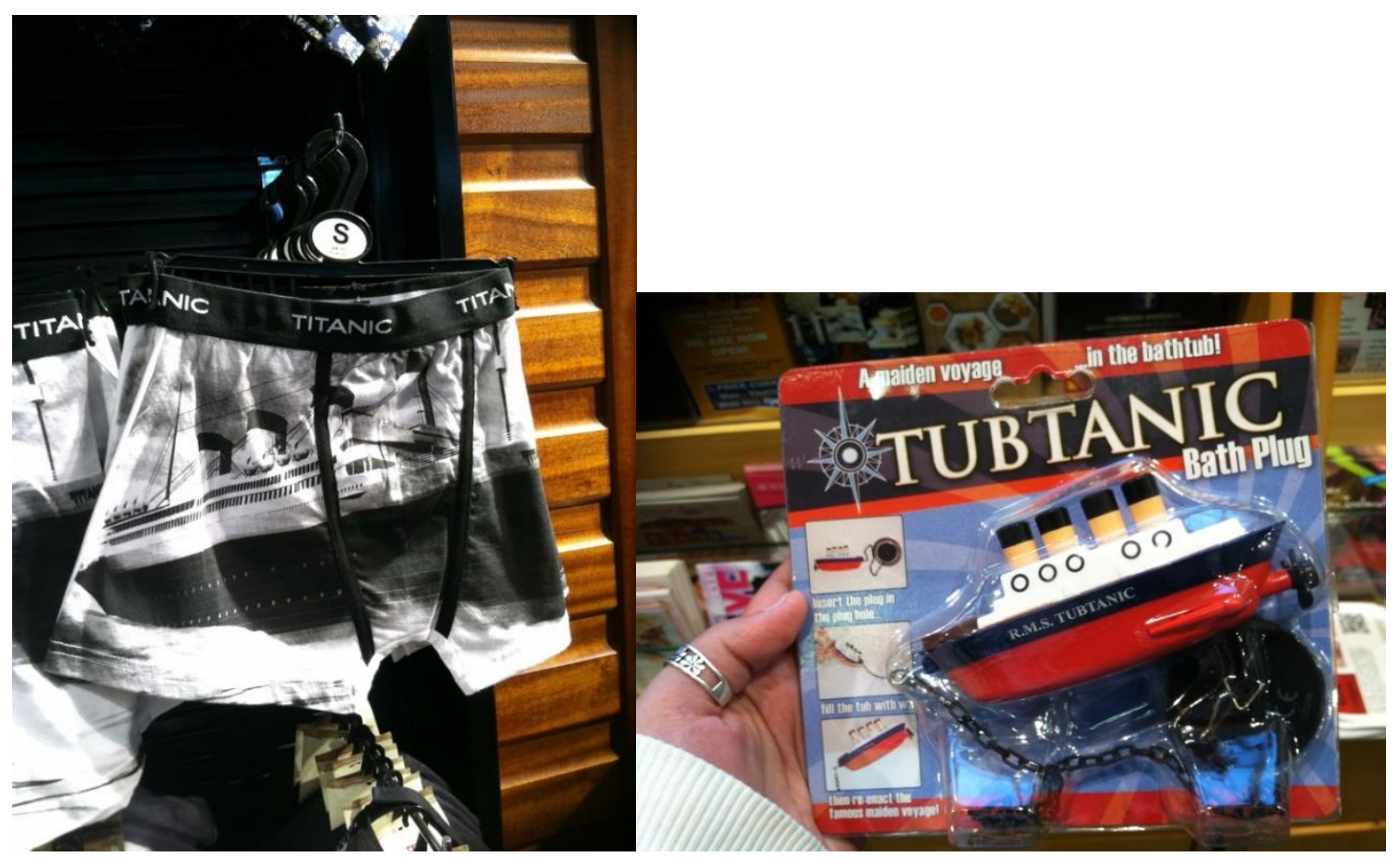

Figure 32 (left): Titanic boxer-shorts and Figure 33 (right): Tubtanic

The contradictions between Titanic Belfast's exhibit and gift shop are like the contradictions found in other conflict sites. The commodification of these sites contradict the sacralization that takes place within spaces of conflict. These sites are sensitive areas either due to death or another impact of the violence enacted within the site's physical space. Local-folk narratives of remembrance are created at sites of tragedy and violence. The touristic narrative invades these spaces and brings with it the peeping and gawking gaze of outsiders (non-locals).

The narrative underlying the exhibits at Titanic Belfast and the Ulster Museum are a part of the official perspective. They neutralize the conflict by either ignoring it as observed at the former, or carefully crafting unbiased language that tiptoes around much of the issues at stake. Official sites, as seen with Titanic Belfast can be appropriated by the local-folk narrative. However, the appropriation of Titanic Belfast does not alter the 
site, instead it inserts the site into the ongoing dialogue of the conflict. In contrast, sites like the Peace Lines have been altered by local folk appropriation.

\section{Localizing Appropriation: Peace Lines}

Since the mid-1990s, depictions of peace and messages of hope and unity have joined the conversation on the walls of Belfast. There has also been a surge of culturally themed murals. These murals have longer lives on the walls of Belfast and Derry than those of more politically leaning themes. It is hard to say with certainty whether the new attitudes expressed in the murals first appeared as local-folk sentiment or trickled down from official rhetoric. The largest concentration of peaceful messages, graffiti, and paintings centers on interface zones and peace lines, permanent structures of brick, concrete and steel erected in the aftermath of the 1969 riots as barriers between flash point neighborhoods in interface zones.

In the past, the majority of muralists and graffiti artists were locals. After the Good Friday Agreement (1998) and the rise of tourism in the following decade, new groups of people were writing on the walls, including tourists and foreign graffiti artists. The messages along the walls are mostly nationalist in nature and range from solidarity with other nationalist groups and movements, such as the nation of Palestine and the American Civil Rights Movement, to images of peace. With the frequency of bus and private tours increasing, the peace lines have become tourist attractions, conflict sites. The wall separating the Falls Road neighborhood from the Shankill neighborhood is the most visited. The City Sightseeing bus tour has a stop along the peace lines where tourists can get off and explore the surrounding areas. Private tours make a stop at the 
walls, and guides urge their passengers to write encouraging messages to the city's inhabitants (figure 34).

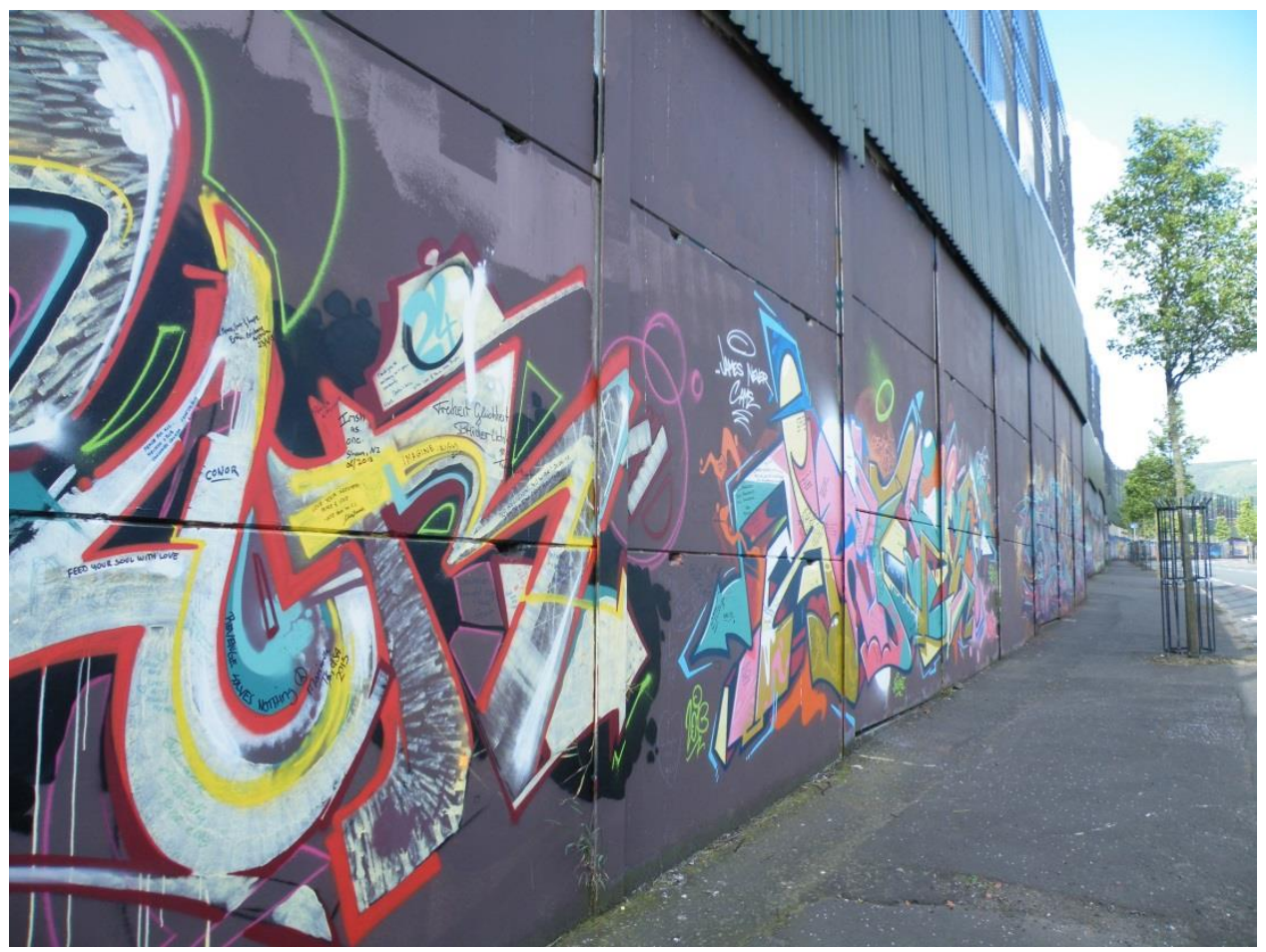

Figure 34: Peace line separating Falls Road and Shankill neighborhoods.

While all guides in the tour company providing our taxi tour try to remain politically neutral in their explanations of the sites along the tour route, both sides of the political spectrum agree that the peace lines represent a contradiction within the peace process of Northern Ireland. On the one hand, a unity of community is desired; a desire to seal the rift between unionist and nationalists has become increasingly evident since the Good Friday Agreement. However, a deep mistrust between communities remains, and a desire to protect oneself and one's community lingers.

The walls remain a reminder of violent struggle and a symbol of segregation. The introduction of tourists, however, has transformed the peace lines into an important piece of history and heritage and a tool for the peace process. The visiting of tourists has 
spurred a new artistic movement. Tourists give the artists an outside audience. Tourists also participate in the conversation by adding their own messages to the walls (figure 35). What was once a bleak symbol of segregation and conflict is transformed into a brightly painted canvas, full of messages of support, love, and peace.

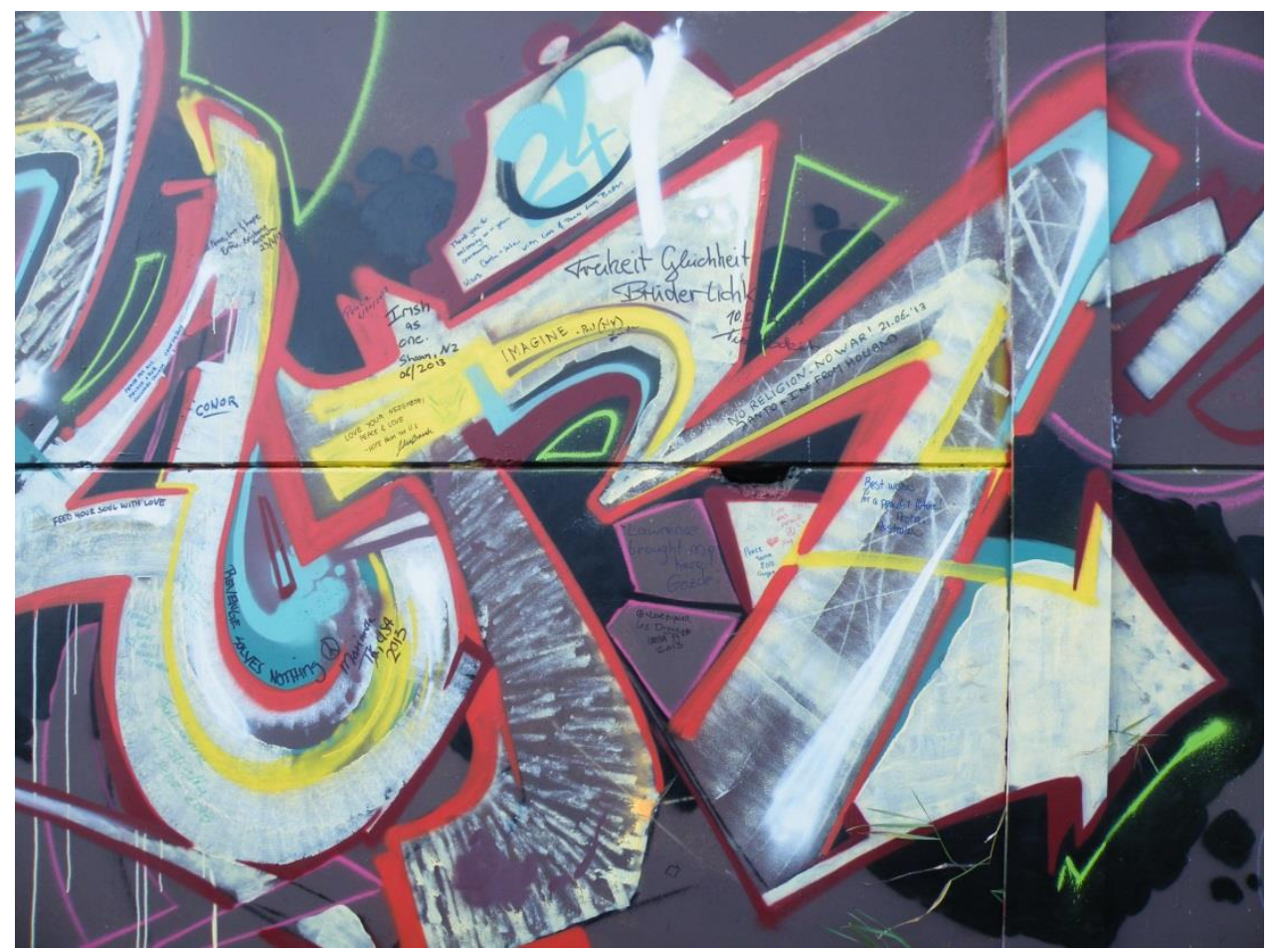

Figure 35: Close-up of tourist messages written on Peace Lines

Through local effort, the gate separating the Shankill and Falls Road neighborhoods has become a peace monument. While the gate still functions, closing every evening and opening in the mornings, the area between the gates (figure 36) is plastered with messages of peace (figure 37) and a peace sculpture (figure 38) was erected. The area is meant to foster positive feeling in the community. Our tour guide spoke of the community's hopes that those who passed through the peace gate would carry peace and love to the other side of the wall, instead of hate and mistrust. The peace 
gate monument was erected in the 1990s after the Army Occupation ended and the city began the long healing process still in effect today.

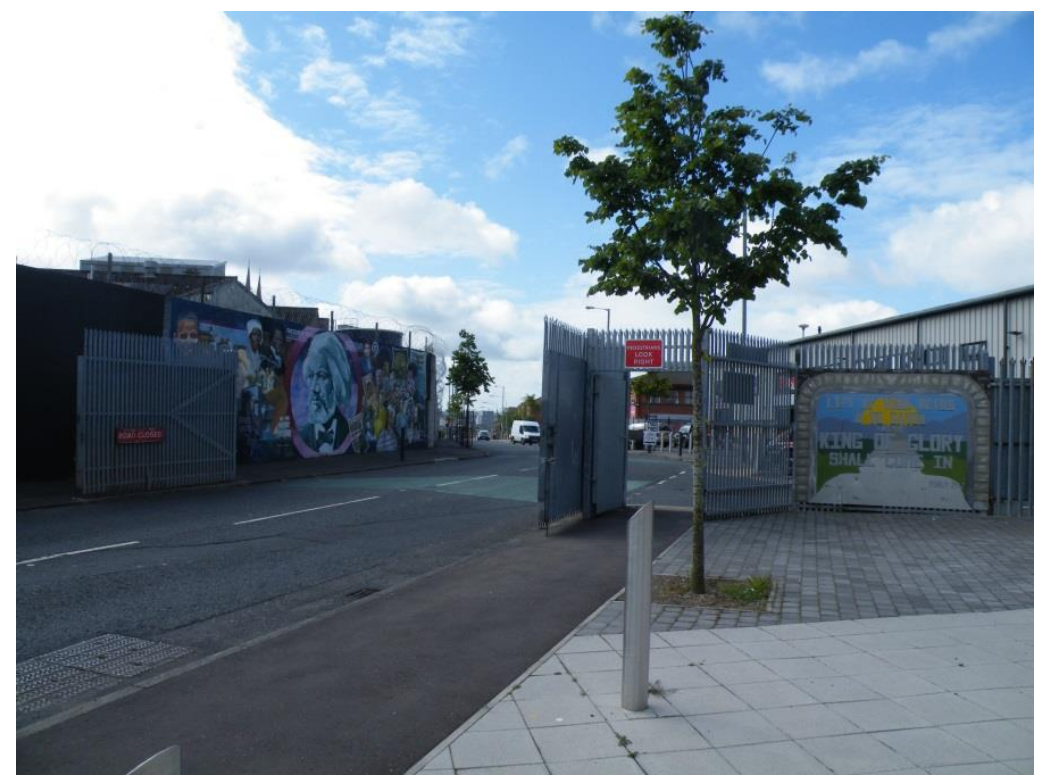

Figure 36

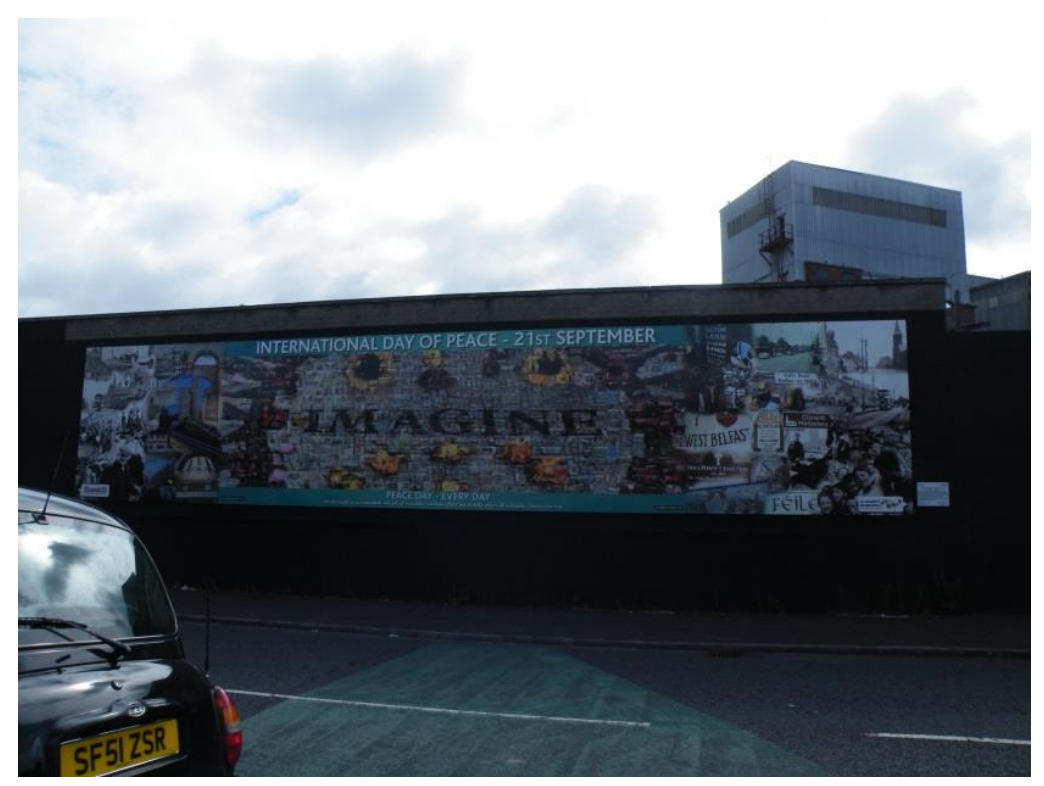

Figure 37 


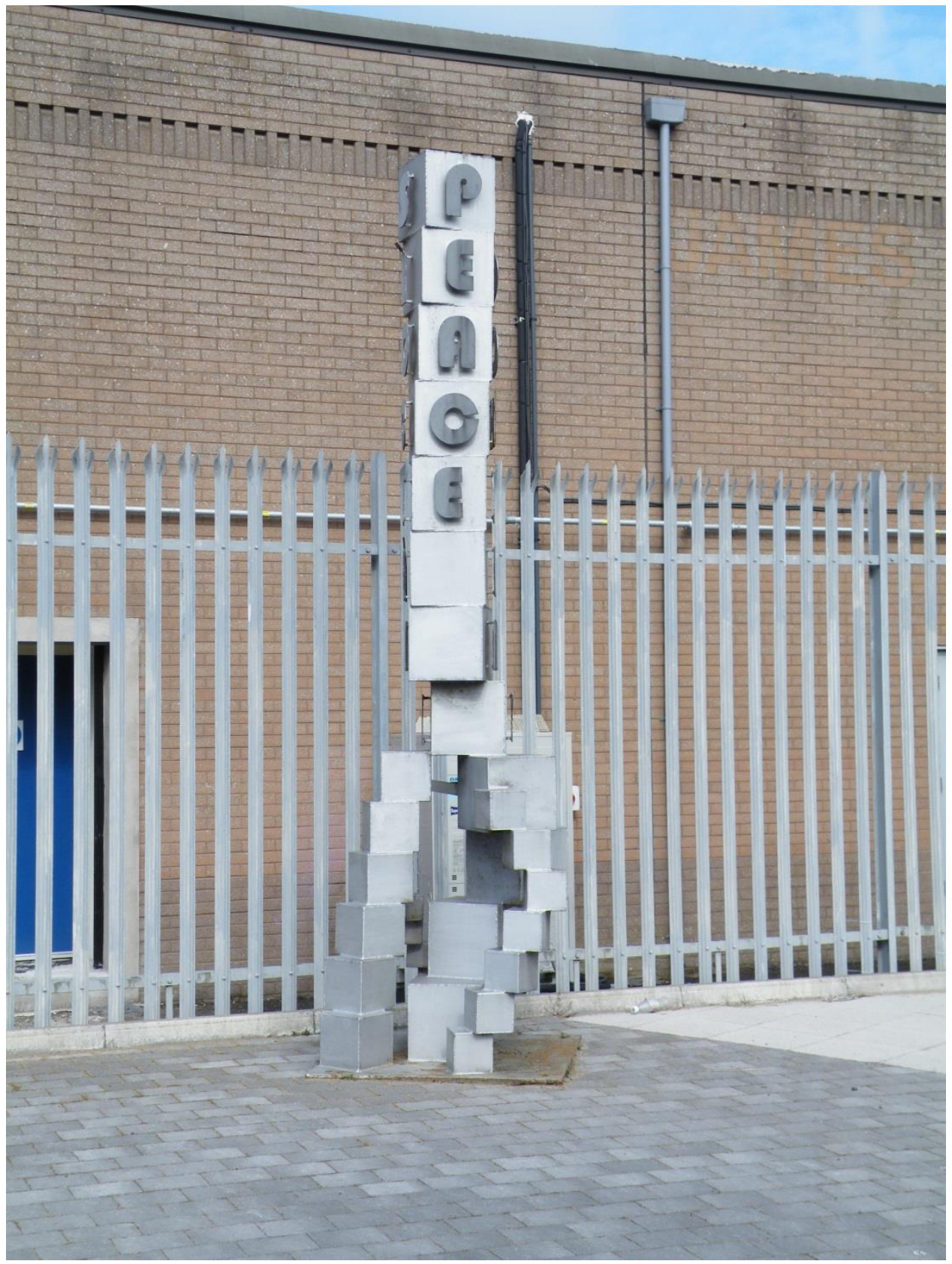

Figure 38

As a part of the touristic process, the peace lines are conflict sites in two senses.

These sites are a response to the sectarian struggle but also bear physical scars from violence. The concrete and brick are marred by pits and missing chunks. Other places along the wall are scorched where makeshift firebombs were thrown not quite high enough to breech the top. These sights are on display for all to see. They are a part of 
Belfast's tale of the Troubles and the healing process that follows, both as a symbol and a physical site. The peace lines, constructed for official use during the conflict have been transformed by the local populace, and through the influence of tourism, from symbols of segregation and oppression, to galleries of peace. The peace lines conclude our look at Belfast's conflict site sampling.

Belfast's offerings of tourist attractions vary in their display and interpretation of local-folk and official narratives. While officialization of local sites is becoming more common, especially with the appropriation of sites connected to conflict, the localization of official sites is also at work within the process of tourism. A very different relationship between the local-folk and official narratives is observed at Derry/Londonderry.

\section{Derry/Londonderry}

The socio-political atmosphere in Derry/Londonderry is different from that in Belfast. Because the area is majority Catholic, the tension of the conflict is less prominent. This can be said of other townships whose citizenship is mostly, if not all, Protestant. However because of Derry/Londonderry's historical significance to many events, the city's historical sites and conflict sites are emphasized to visitors. At the visitor center, brochures and pamphlets for various historical walking tours, historical sites and sites associated with the sectarian conflict and Free Derry uprising dominate the racks.

The official and local-folk narratives are less distinct in Derry/Londonderry than in Belfast because there is less division among the populace. The boundaries between narratives blur and become less important. The lack of overt conflict in the city has 
changed the focus of the narratives away from conflict and towards cultural and economic success. This includes tourism. Derry/Londonderry is touristically presented as a city of culture. It was the UK City of Culture in 2013, where arts, music and history are emphasized - and conflict is examined as a part of that history.

Conflict sites are not only presented as part of the city's history; they are also treated as highly significant. Derry/Londonderry was the epicenter of many key events of the Troubles. It was the focus of the 1969 civil rights march that began the unrest, Bloody Sunday (1972) which brought the city international attention as recently as 2010 with the publication of the Saville Inquiry (Bloody Sunday report). Instead of trying to distance themselves from the events of the Troubles, the city of Derry/Londonderry has embraced them as a part of their heritage, a trend that is taking hold in other parts of Northern Ireland.

The nationalist retelling of events in Derry/Londonderry starkly contrasts with that of the carefully crafted language of heritage that is found in Belfast. The sites presented in the following section were visited on two separate occasions, once in 2009 and again in 2013. However I will be focusing on my 2013 visit to the area since much had changed due to the Walled City Signature Project and the city being featured as the UK City of Culture. I spent less time in Derry/Londonderry than I did in Belfast, and most of that time within the Derry Bogside. The treatment of Derry/Londonderry will not be as deep as my account of Belfast.

The lack of overt conflict within Derry/Londonderry has shaped the narratives displayed at conflict sites in a different way than in Belfast. In Derry/Londonderry the narrative aligns more closely with nationalist rhetoric and the displays have a biased 
towards a nationalist representation of history, rather than a neutralized version. Most sites in Derry/Londonderry are officially produced. All sites examined in this section were officially produced, however some spaces have been appropriated by locals as a means of voicing their contrasting narratives.

\section{Official Production: The Museum of Free Derry and the Peace Bridge}

Located north of Free Derry Corner, the Museum of Free Derry “was established by the Bloody Sunday Trust to tell the story of the civil rights movement and the creation of Free Derry in the 1960s and 1970s" (Museum of Free Derry). The Museum focuses on the history of Free Derry including the Battle of the Bogside, Internment, Bloody Sunday, and Operation Motorman. The museum is a highlight on the Free Derry walking tour and a major stop on the City Sightseeing Derry/Londonderry hop on/hop off bus tour. The Museum of Free Derry is a part of the National Civil Rights Archive, which is housed inside the museum. The museum itself is text heavy and relies on the visitor's interest in the Northern Irish civil rights movement or Derry/Londonderry's history of civil rights.

There are similarities in the way the subject of sectarian violence is treated between the Museum of Free Derry and the Ulster Museum. Both treat the topic with respect, and the understanding that the topic is both controversial and emotional. Where the Ulster Museum does its best to give an unbiased overview of the Troubles, the Museum of Free Derry delves deeper into the conflict, examining more specific events with a nationalist biased narrative. Its organizers hope to both educate future generations about Northern Ireland's violent conflict and to keep a record of the struggle. The museum portrays the city's official narrative, markedly different from the narrative 
offered at other museums and exhibits across Northern Ireland. This is just one example of how narratives and perspectives differ from place to place. The Peace Bridge over the River Foyle offers another take on the official perspectives within Northern Ireland.

One of the first sights a visitor sees as they disembark from the train in Derry/Londonderry is the Peace Bridge (figure 39). The self-anchored suspension bridge $^{27}$ over the River Foyle opened 25 June 2011 and connects Ebrington Square to the city center. The bridge is open to foot and cycling traffic and is a part of a larger cycling loop that connects the two sides of the city. The bridge is a part of a wider city regeneration project and greenway plan and is meant to be a symbol of hope for the divided city (Derry City Council).

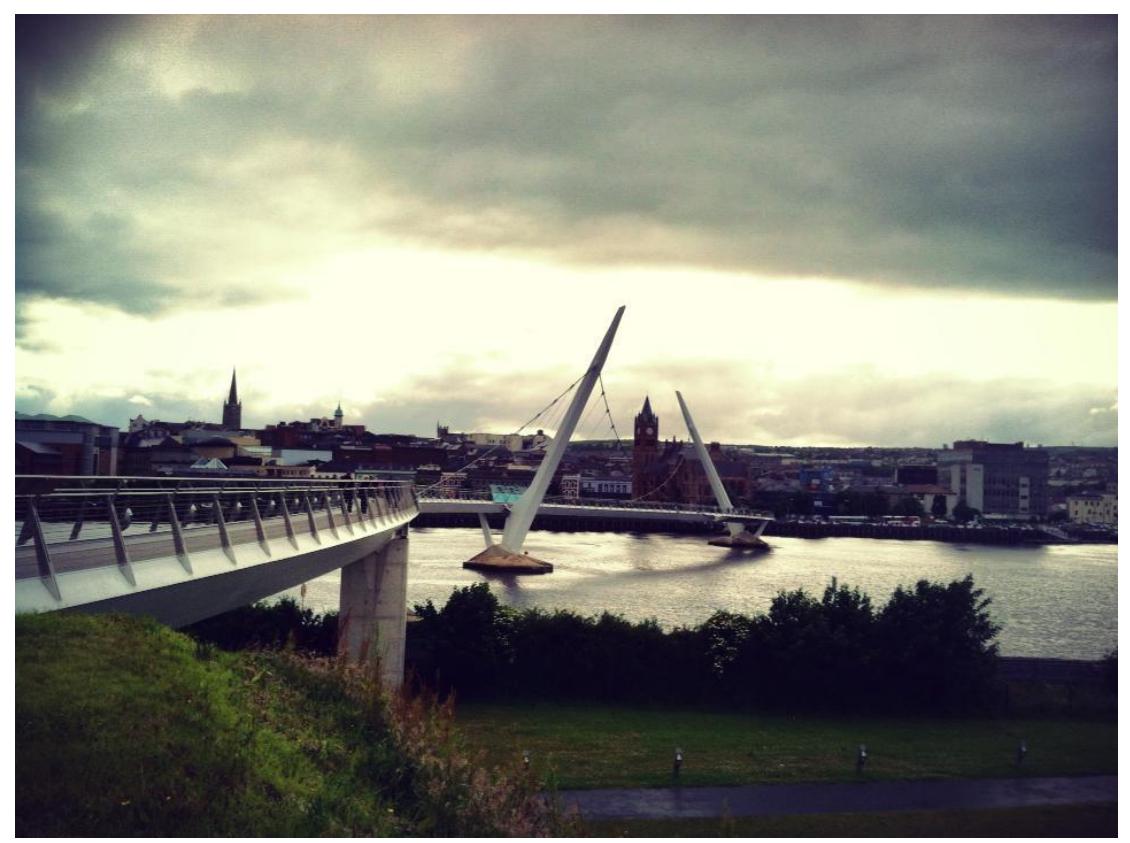

Figure 39

\footnotetext{
${ }^{27}$ The main cables of the bridge are anchored to the ends of the road deck of the bridge instead of the ground.
} 
Initially intended to literally bridge the gap between the largely nationalist "Cityside" and unionist "Waterside" of the city, "the Peace Bridge physically and symbolically unites both sides of the river.

The peace bridge was developed with beautification of the city and tourism in mind. As a conflict site, the bridge does not have any physical connection to violence. Instead it is a reminder of the violent past that divided Derry/Londonderry and is a symbolic transformation from division to unity. With tourist traffic in mind, the city hopes to regenerate river traffic and use for leisure with the creation of new river cruises that highlight the bridge as a sight (Discover Northern Ireland). The bridge is a symbol of the official perspective's emphasis on peace and unity in the city of Derry/Londonderry. The bridge is steeped in the socio-political struggles of the past. The city officializes the conflict by relegating it to the past.

\section{Localizing Appropriation: The Derry Bogside}

The Bogside of Derry/Londonderry is an area located northwest of the original city, just outside the walls on the Cityside. The Bogside is home to Free Derry Corner, an area of Derry/Londonderry that claimed nationalist 'independence' for itself in 1969 after the Battle of the Bogside. The self-declared autonomous region remained in existence from 1969 until 1972, after the no-go area barricades were destroyed by British troops during Operation Motorman.

Today, the area known as Free Derry Corner (figure 40) is a memorial site for those killed in the events of Bloody Sunday and continues to declare the Bogside's independence from Unionism. Originally the words "You Are Now Entering Free Derry" were painted on the side of a house just outside the walls of the old city. While 
the rest of the house has been demolished, the gable and mural is a monument to nationalism. Located in the middle of a roundabout, Free Derry Corner is surrounded by a black iron fence. It is flanked by the house gable on one end and a memorial to the hunger strikers of Maze Prison/Long Kesh H blocks (figure 41) at the other.

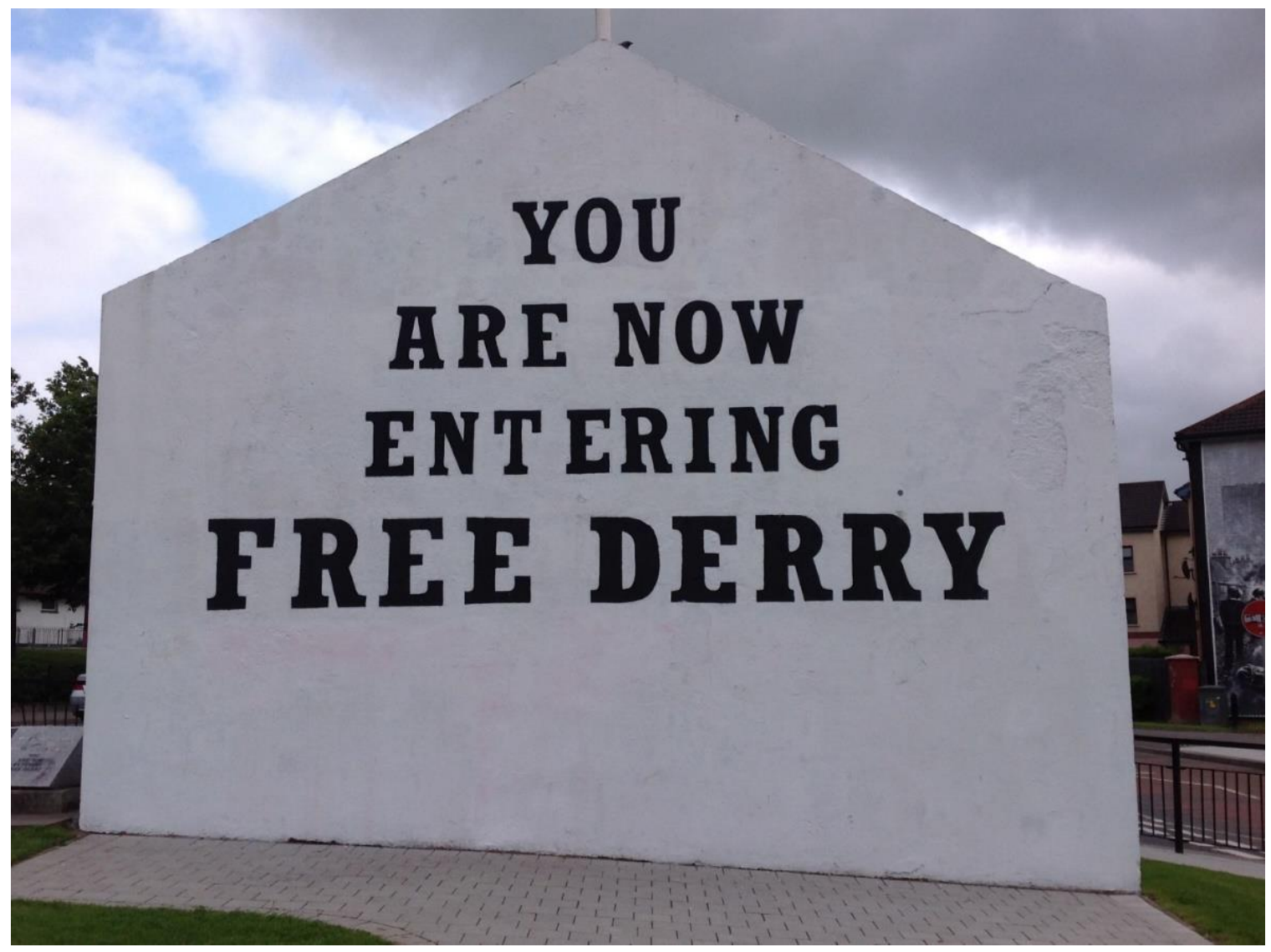

Figure 40: Free Derry gable and roundabout

The Guide to Free Derry plaques (figure 42 ) are posted along the fence around the inside of the roundabout informing visitors of the Civil Rights Movement, Bloody Sunday and general information on Free Derry Corner. The area is easily accessible via bus, taxi or walking and is highlighted in various tours. The Bogside History Tour offers visitors a chance to "learn about Bloody Sunday from those who were directly affected by it" (Bogside History Tour brochure). 


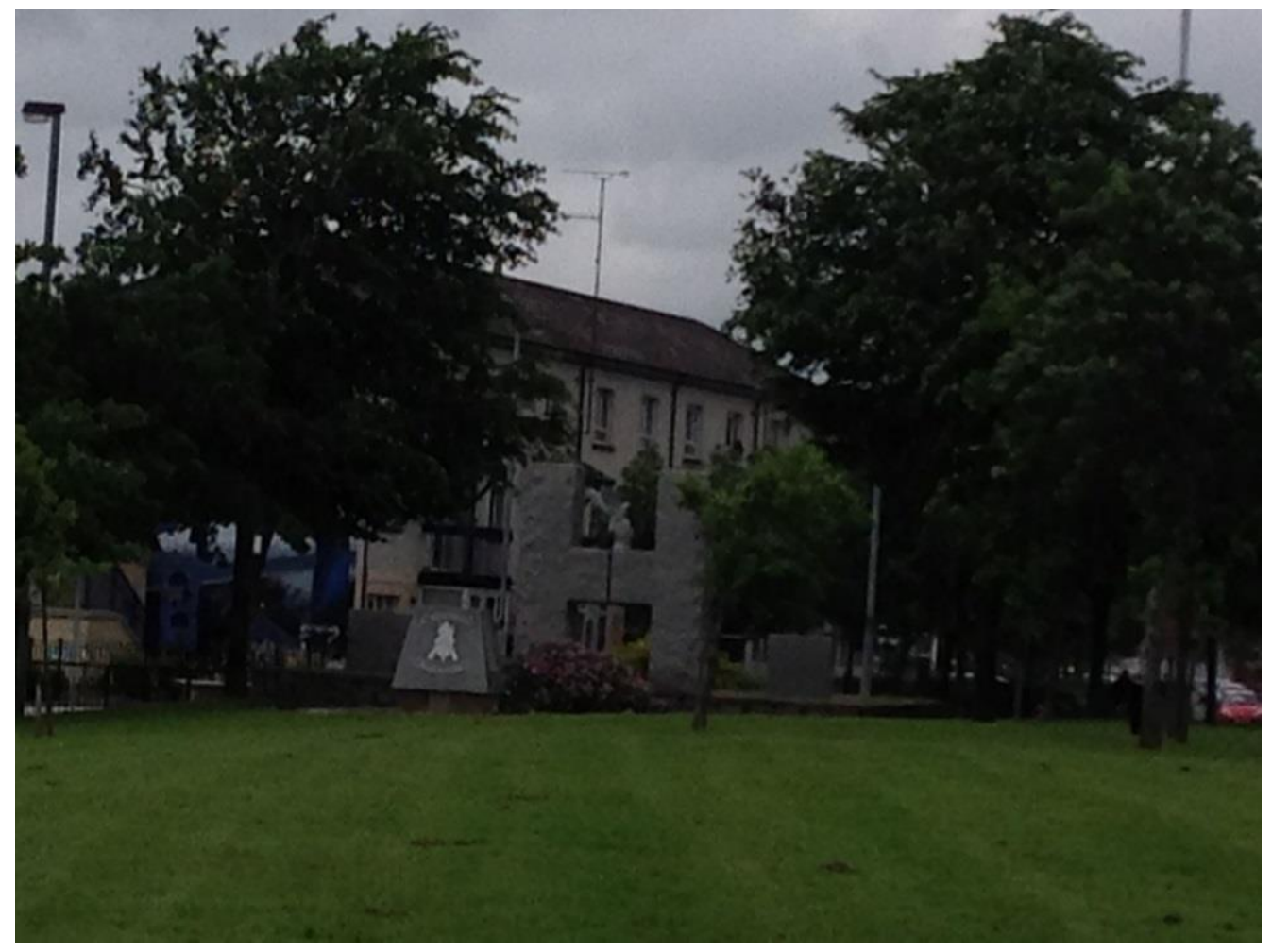

Figure 41: Maze Prison/Long Kesh H Blocks Memorial

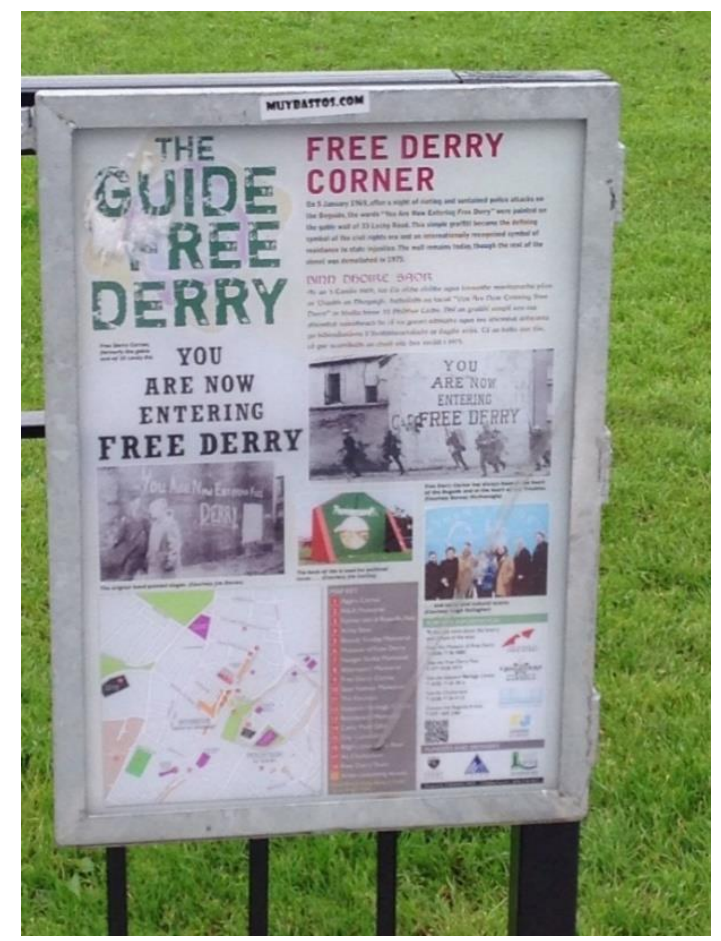

Figure 42: Guide to Free Derry 
Free Derry corner has been transformed into a tourist site with the installation of information boards and plaques. As the site of multiple riots and clashes, Free Derry Corner is very clearly a conflict site. Narratives clash in Free Derry Corner. The area can overwhelm the visitor because it is packed with murals, plaques, information boards, monuments and graffiti. Official and local-folk perspectives vie for the visitor's attention. Officially sanctioned monuments stand near locally produced graffiti.

Officially printed information boards showcase the region's history, next to makeshift bulletin boards declaring challenges to that very same history.

The installation of the plaques and information boards transforms the space into a living museum. The area reminded me of the Ulster Museum's Troubles Exhibit, except it was outdoors and alive with the daily movements of the community's residents. The 'exhibits' of Free Derry Corner were not as carefully crafted or worded as those at the Ulster Museum. In Belfast, the communities have an uneasy relationship with one another and peace is a balancing act that could be toppled at any moment by even the smallest of incidents. This is not so in Derry/Londonderry. Instead the uneasiness that is palpable in Belfast seems to have almost entirely disappeared from Derry/Londonderry. There is a willingness to talk about the past, particularly the sectarian conflict, with an openness not found in other cities. The words on plaques and information boards aren't as guarded or carefully selected so as not to offend as they are in Belfast. Dissidence is not hidden away from the visitor's view. Instead it is on display.

The Bogside Artists, a group of muralists in Derry/Londonderry who wish to promote remembrance and peace throughout Northern Ireland, painted most of the murals depicting the events of Bloody Sunday (figures 43-44). 


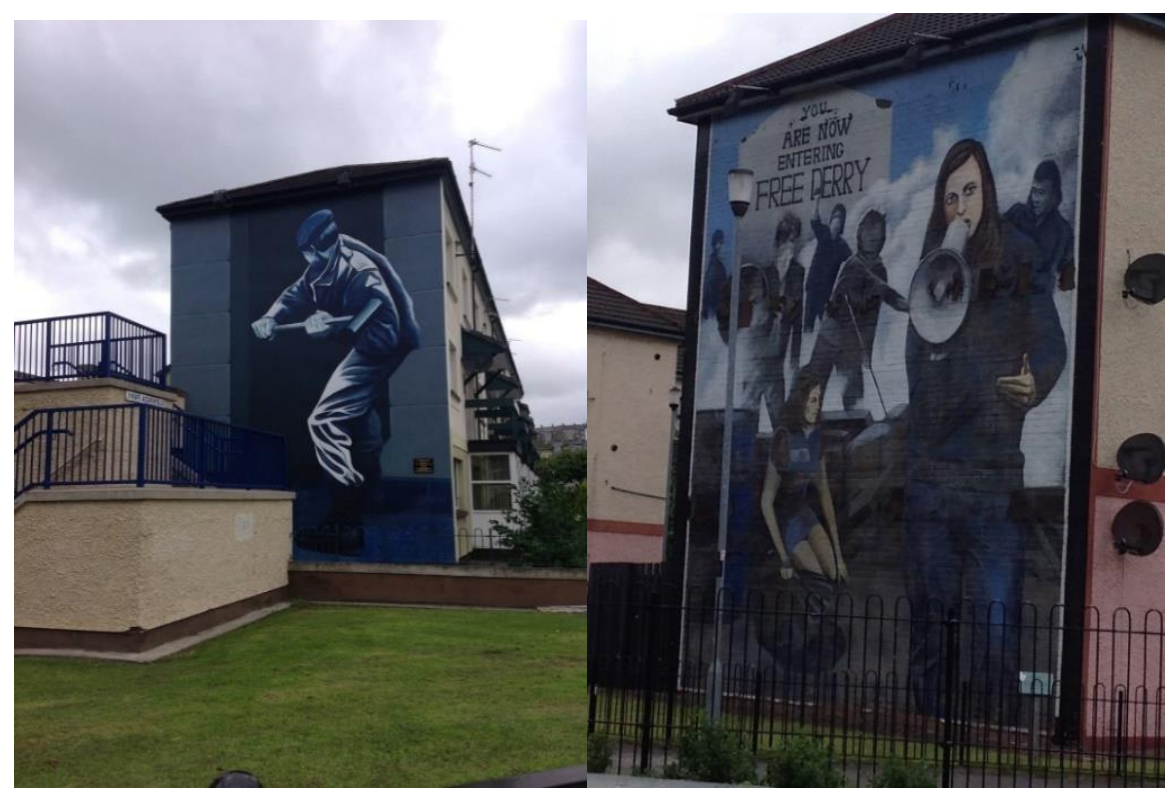

Figure 43 (left): British military man breaking into flats on Bloody Sunday and Figure 44 (right): Bernadette Devlin Bloody Sunday Protest mural

One of the most iconic murals in the Bogside, 'Bloody Sunday' (figure 45), shows a group of men carrying a dying Jackie Duddy, flanked by a crowd of protestors and Fr Edward Daly waving a white flag next to a British soldier standing on a bloodied Civil Rights banner. The image is a result of a photo montage compiled of film footage and news reel images, much like 'The Petrol Bomber' (figure 46).

'The Petrol Bomber' depicts scenes from the 1969 Battle of the Bogside behind a young boy in a gas mask holding a petrol bomb. In response to rioting on 12 August 1969, RUC officers deployed 1,091 canisters of CS gas in the densely populated Bogside. The RUC's incursion into the Bogside area was met with violent resistance. Behind the boy in the mural are two RUC officers standing on the edge of a cloud of CS gas with one of the now demolished housing blocks rising out of the smoke. 


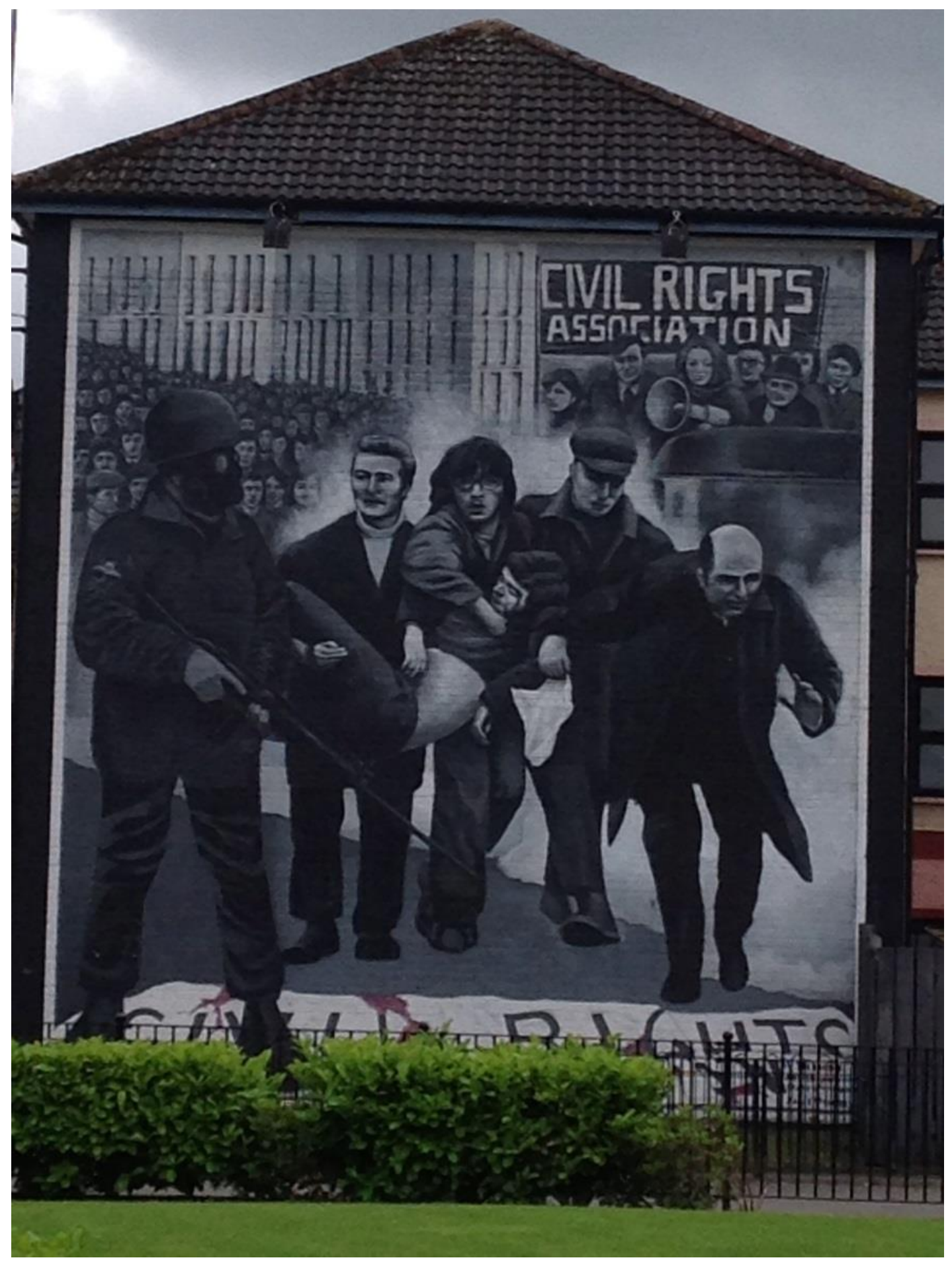

Figure 45: Jackie Duddy Bloody Sunday mural 


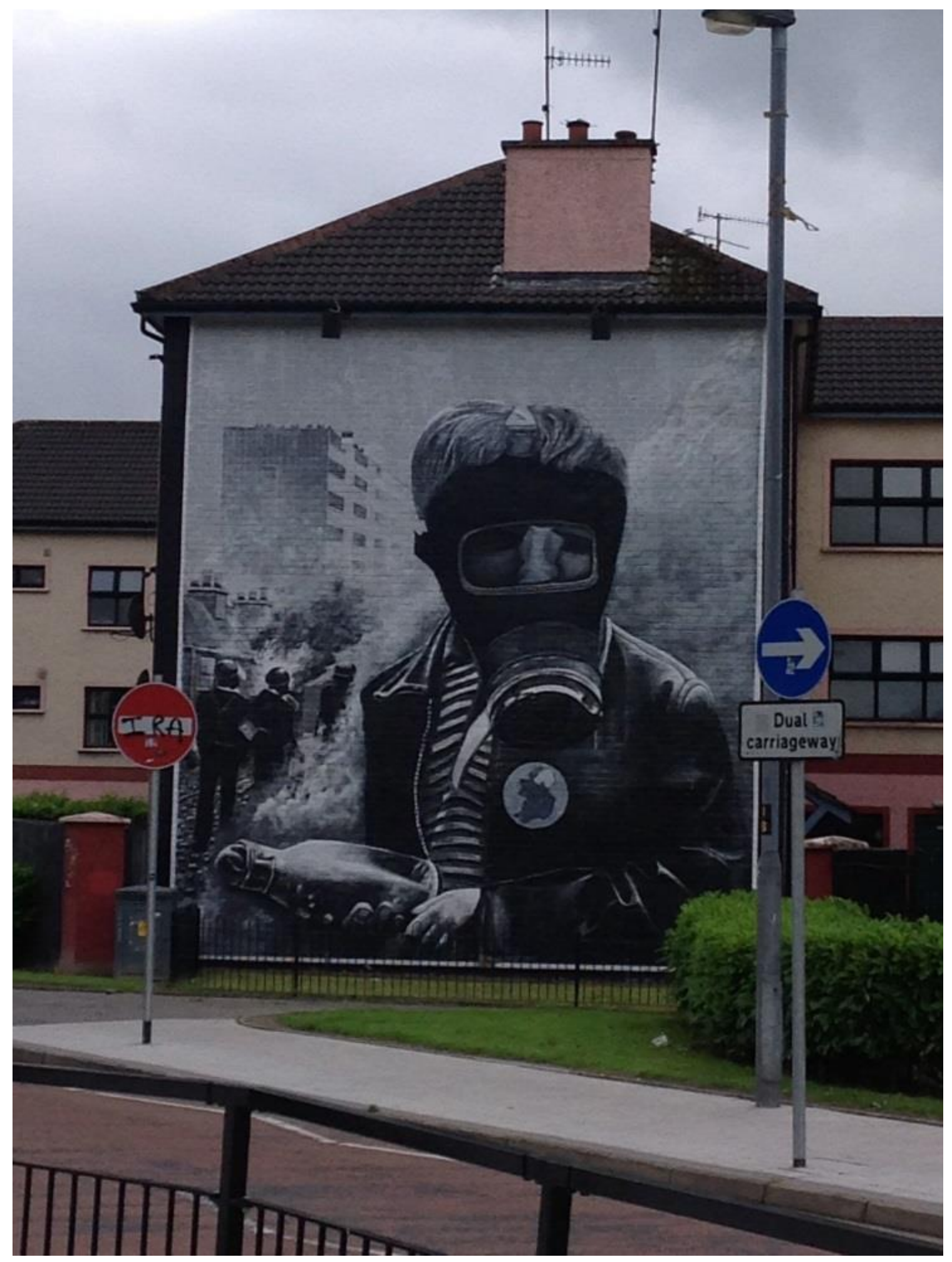

Figure 46: The Petrol Bomber 
During my visit in 2013 most of the murals appeared to be clean and newly retouched. One exception was 'The Saturday Matinee: The Rioter' (figure 47), recently damaged with a power washer. The simplified image depicts a young man holding a rock and standing behind a barricade 'facing off' with a British Army Humvee. The image is meant to represent a typical day in the Bogside from 1969 throughout the early 1970s when "riots where commonplace with many happening on Saturday afternoons" (CAIN archives).

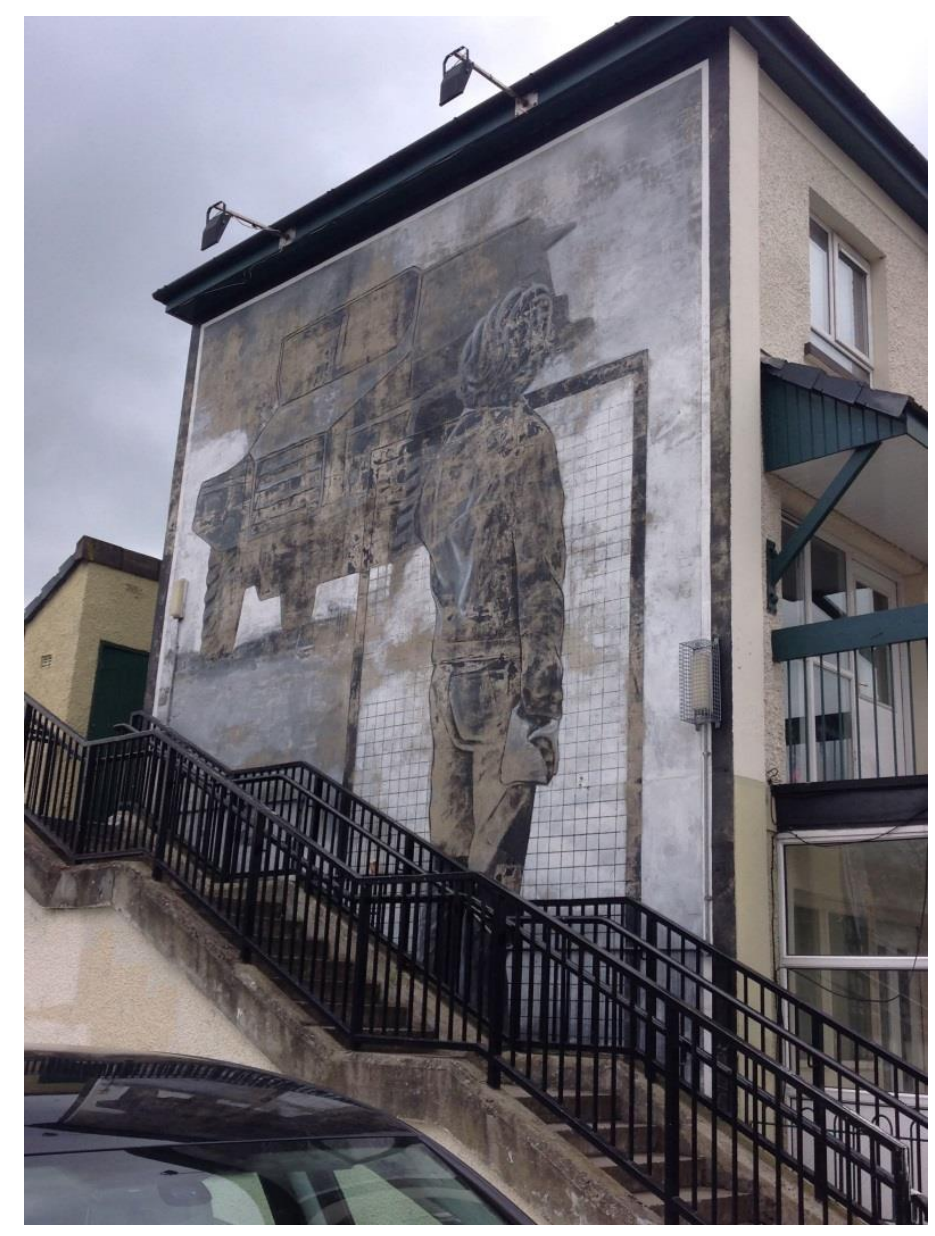

Figure 47: The Saturday Matinee: The Rioter

As in Belfast, the walls of Derry/Londonderry are host to more than officially sponsored murals. Pop-up murals can be painted on any open space. Pop-up murals, 
unlike officially sponsored murals, remain for varying lengths of time. They can be visible for a day, a few weeks, even a few years; a few murals that began as pop-ups are now retouched and repainted year after year. Pop-up murals are more likely to be vandalized than their 'officially' sponsored counterparts and most will be painted over instead of retouched. In Northern Ireland pop-up murals are defined somewhere between graffiti and officially sponsored paintings. They fall in the category of street art along with works by Sten \& Lex (Italy; stencils), Shepard Fairey (US; pasteups/collage), Phlegm (UK; murals) or Banksy (UK/International; stencils). Pop-ups represent an individual artist's local-folk perspective. They are not a part of the narrative carefully crafted for visual consumption. Pop-ups intrude upon the official narrative. They remind the viewer that there is a hidden process, a dialogue between what is the officially sanctioned narrative, and the local-folk perspective. The content of a pop-up mural or the artist's notoriety can lend longevity and community tolerance to these murals, Banksy is a well-known example of this. The artist's notoriety has transformed his graffiti from a product of vandalism to a highly sought-after work of art. In Northern Ireland, sectarian pop-up art is tolerated in certain areas of the community because of the messages conveyed within the painting. The paintings themselves are more than a tag or work of graffiti; they are an unofficial statement, usually from within the community. Pop-ups are reactions to current events, an artist's response to certain happenings within his/her community or on a more global scale. Other topics include messages of peace and memorial art. 
Murals and official plaques share space with graffiti and unofficial signage in the Bogside. Hastily erected bulletin boards abound. One board was filled with graphic autopsy images and a form letter to the family from the Ministry of Defence (figure 48). The brother of James Seamus Bradley had requested an apology for his brother's death during Operation Motorman in 1972. The letter informed Mr. Bradley that his request was denied. The bulletin board was erected on the fence around white washed apartments recently constructed in the Bogside roundabout.

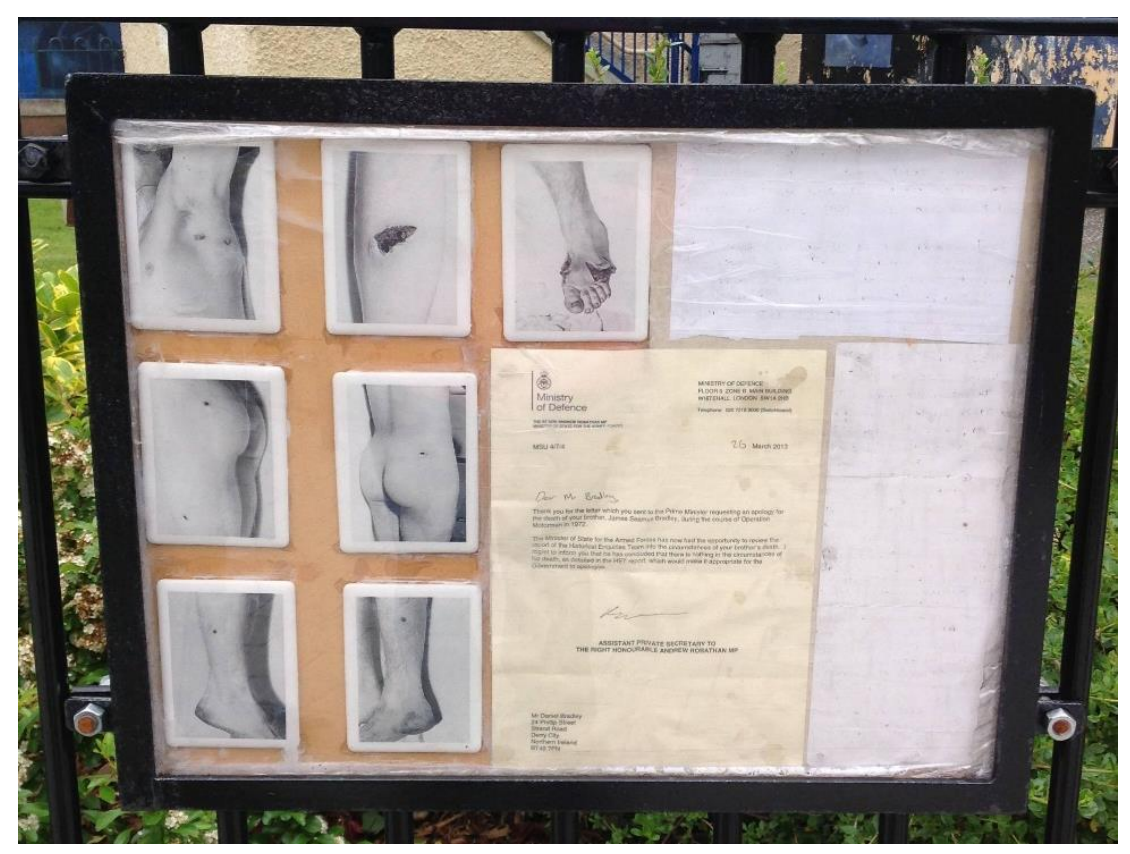

Figure 48: Bradley Bulletin

Across the road from the makeshift bulletin board, "RIP DOLOURS PRICE" and "IRA" (figure 49) were hastily painted on the old city walls in white. Neither the bulletin 


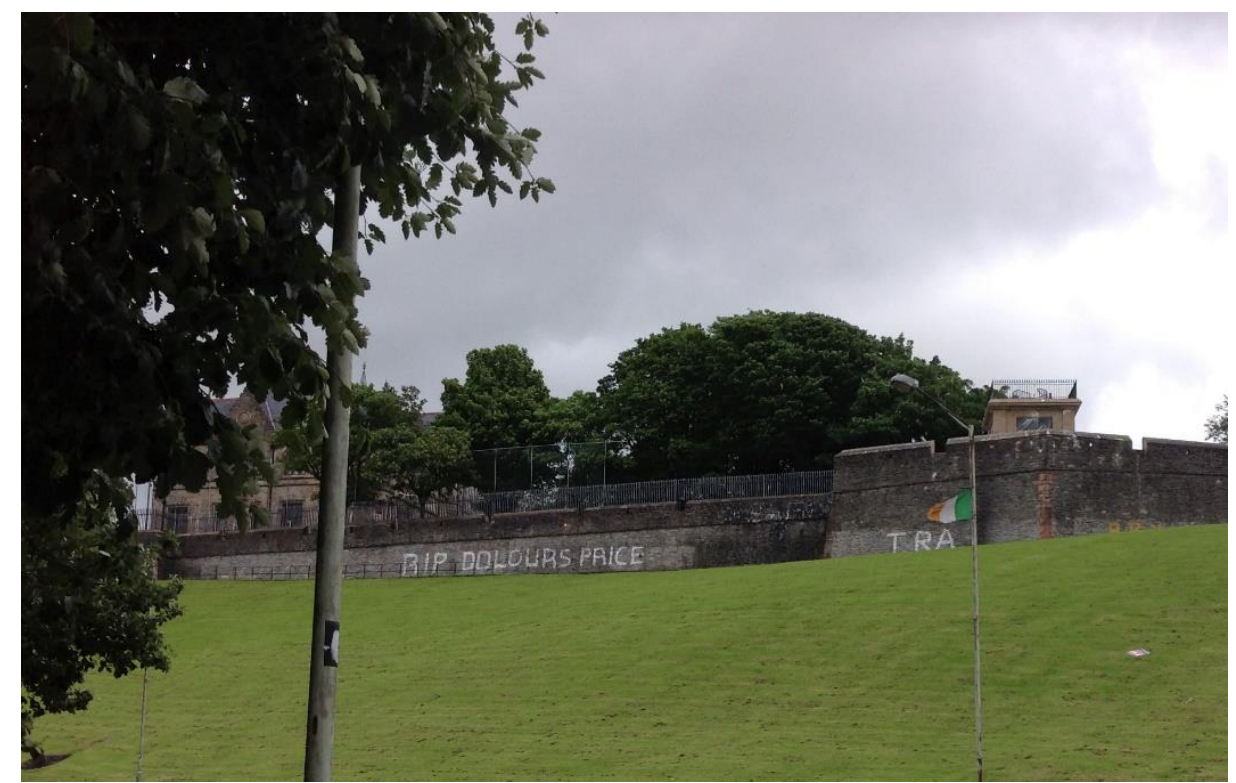

Figure 49: 2013 graffiti on Bogside of Derry Wall

board nor that particular graffiti was present in 2009; instead "END INTERNMENT"

(figure 50) was the white painted message graffiti artists had for passersby. The bulletin boards and white graffiti are jolting images juxtaposed with the monuments of peace and historical murals. They are reminders that the conflict is not over, and that local-

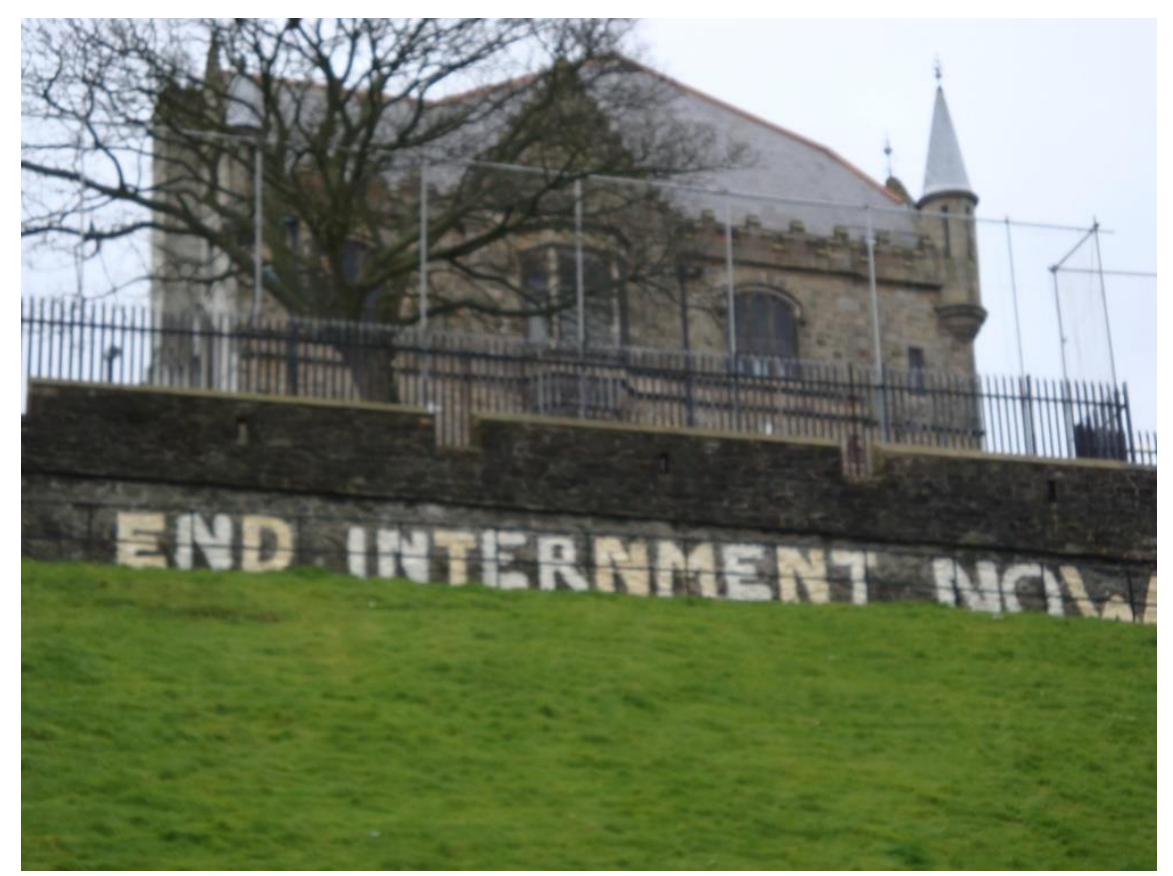

Figure 50: 2009 graffiti on Bogside of Derry Wall. The paint was still wet when came across it. 
folk/official distinction does not only apply to narratives.

Derry/Londonderry's perceived lack of conflict as promoted by the official narrative of the city stands in stark contrast to Belfast's official narrative on conflict. While the former seemingly embraces the events of the past through vibrant officially produced displays and museum exhibits, the latter attempts to ignore or neutralize the conflict. Conflict tourism will continue to develop within Northern Ireland as the processes of tourism and conflict continue to coexist within the region. 


\section{CONCLUSION}

Conflict tourism in Northern Ireland grew out of the general growth of tourism in the region. The island of Ireland has a long history of using tourism as a solution to economic crisis. In the $18^{\text {th }}$ century, the lack of industrialization, the emergence of the Romantic Movement, and the creation of mass market tourism allowed Ireland to develop a thriving tourist economy. Heritage tours aimed at the descendants of emigrants were developed and marketed as far away as San Francisco. In Northern Ireland, the Fermanagh lake lands and the Antrim Coast were developed with touristic endeavors in mind. This economic strategy experienced a number of interruptions. The outbreak of World War I, the Irish Civil War, World War II, and the Troubles all affected tourist related income and the flow of tourists on the island. During the Second World War, the UTDA marketed the island to foreign troops stationed in the region, in hopes that they would visit post-war.

After the war, the government played an increasingly active role in touristic expansion. The UTDA was replaced by the NITB and became a subordinate of the Ministry of Commerce. By the 1950s, tourism was on the rise, but had not reached the potential that NITB members and government agents envisioned. A joint marketing effort was made between Northern Ireland and the Republic of Ireland, but this all came to a halt after the violence of 1969. The Troubles created a public relations nightmare for the tourism industry. As violence increased throughout the 1970s, the government's 
attention shifted away from tourism almost completely. Media outlets worldwide covered the conflict, and tourist numbers rapidly plummeted. They would remain low until the mid-1990s.

While small advances were made in the mid-1990s, including a second joint marketing effort with the Republic of Ireland, tourism would not flourish again until after 2004. The peace process that began in 1998 paved the way for economic expansion, including touristic endeavors. In 2004 a major rebranding scheme was undertaken and it has been counted as a success as each year with record numbers of visitors holidaying in Northern Ireland. But what has this re-branding meant for local peoples, their culture and their locally private spaces? As tourism industries appropriate local murals, memorials and other sites of remembrance, they attempt to make sense of the sites within the official narrative of the conflict.

Conflict sites are an important part of the peace process. The appropriation of conflict sites as tourist sites became a part of official tourism practice in 2008. Some conflict sites are appropriated and marketed as heritage sites for tourists to visit. Others have been created specifically with tourism in mind (museums, exhibits). Still more are touched by the sectarian conflict through community discussion of the sites - a reminder that socio-political conflict is still a part of society in Northern Ireland. The transformation of these places into tourist sites allows for a dialogue between unionists and nationalists to take place in areas previously cut off from one another. The sites become liminal spaces where everyday social norms and behaviors are suspended and allow those who would normally be unwelcome within these areas to pass through undisturbed within the touristic bubble. The dialogue between the local-folk and official 
narratives is prevalent at tourist sites, where they intersect, overlap, and highlight the contradictions between conflict and tourism.

Conflict tourism is a process that shows the relationship between local-folk and official perspectives, and that they are spatially differentiated. The boundaries between the official and local-folk narratives, originally driven by sectarian divide, are less distinct than they might seem. They overlap one another in different periods and locations. The tourist industry often attempts to follow the official narrative when creating sites for consumption. However this highlights a disconnection between official and local-folk as the official tends to be further removed from 'reality'. In Belfast, this distinction is emphasized when contrasting official sites like The Ulster Museum with locally produced sites, murals, and memorials that have been appropriated for tourism. The official focuses on neutrality of language and a less detailed overview of a period in time. The neutral language stems from the official narrative in place after the peace process began in 1998. The local-folk offers a more detailed and unselfconsciously biased narrative of those who experienced the events of the Troubles firsthand. In contrast to Belfast, the sites at Derry/Londonderry are produced officially but have become localized. The sites are accepted as a part of the city's reality and as major points of interest in its history.

Tourism as an educational tool can aid in the understanding of both parts of Northern Ireland's divided society. Tourism opens previously closed and locally private areas to the gaze of strangers and their foreign interpretations. This interaction between local residents and foreign tourists is best captured at the Peace Lines, where tour guides encourage visitors to write messages to the community on the walls in permanent ink. 
The message wall is an extension of the nearby International Wall of Art painted by two community members, a Catholic and a Protestant. Their cooperation in creating the International Wall of Art is a conscious effort to end sectarianism and to bring together the divided communities of Belfast and Northern Ireland (McLoughlin 2014). Many cross-community building mural projects have transformed the Peace Lines, and inspired the message wall. By writing a message upon the Peace Line - a wall meant to separate the combatant communities of Belfast — the visitor feels as if they are a part of the peace process. The visitor is also given the sense of being a part of the community, and a part of the conversation on conflict and peace. This is true at least within the communities situated upon Cuper Way in Belfast.

Following periods of violent unrest, governments have looked to rebuild politically and economically. Tourism is often considered a viable option for reintegrating sites into market economies. This option seems to develop in steps. First, the region is opened to mass tourism. In most cases the region is affordable due to its economic marginality. The affordability is advertised along with the marginality. Second, the region's 'uniqueness' becomes a selling point. Part of the "uniqueness' is the region's history, which includes violent events. Tourist enterprises are appealing to several types of tourist when advertising violent events as tourist attractions: historical enthusiasts, adventure tourists, the morbidly curious and others. Through the exploitation and transformation of politically charged spaces into places of touristic consumption, regional tourism industries capitalize and increase the popularity of conflict tourism. Following the examples of peace processes in former or dormant ${ }^{28}$ conflict zones,

\footnotetext{
${ }^{28}$ The conflict in the region has not successfully been resolved. Violence still occurs but on a more manageable scale.
} 
memorials of the violent past are permanently erected at sites communities deem important. Memorials of war and sites of remembrance dot the global landscape from Normandy to Sarajevo to Tokyo to Washington DC.

Tourism in Northern Ireland takes its place among these other examples. The Northern Irish solution is, in fact, a complex process involving much more than the official perspective. The concept of conflict tourism calls attention to the tension-filled dialogue between the official and local-folk perspectives. It helps us understand all aspects of a region's heritage, and the relationship between tourism and conflict. Conflict tourism is a worldwide phenomenon. Because it is complex and dynamic, it needs analysis from various angles. This thesis is one such analysis. 


\section{REFERENCES}

Alluri, Rina M. (2009) "The role of tourism in post-conflict peacebuilding in Rwanda" in Swiss peace Working Paper 2, Bern: Swisspeace.

http://www.swisspeace.ch/typo3/fileadmin/user_upload/pdf/Working_Paper/2_20 09.pdf

Aretxaga, B. (1997) Shattering Silence. Princeton: Princeton University Press.

BBC News Norfolk. "'World's last' WWI veteran Florence Green dies aged 110" from BBC News Website, 7 February 2012. Accessed 6 October 2014. http://www.bbc.com/news/uk-england-norfolk-16929653

Belfast Mural Tours website. Accessed 8 July 2014. http://www.belfastmuraltours.com/\#

Blom, T. (2000) "Morbid Tourism: A postmodern market niche with an example from Althrope" in Norwegian Journal of Geography 54(1):29-36.

Bowman, M. S. and Pezzullo, P. C. (2010) “What's so 'Dark' about 'Dark Tourism?: Death, Tours and Performance” in Tourist Studies 9(3):187-202.

Butler, Eamonn (2011) "The Condensed Wealth of Nations and The Incredibly Condensed Theory of Moral Sentiments" from The Adam Smith Institute Website. Accessed: 17 March 2015. http://www.adamsmith.org/sites/default/files/resources/condensed-WoN.pdf

CAIN Web Service (Conflict and Politics in Northern Ireland). Accessed January - June 2015. http://cain.ulst.ac.uk/index.html

Cashman, R. (2008) "Visions of Irish Nationalism" in Journal of Folklore Research 45(3): 361-381.

Connell, Monette (2008) The Medieval Hero: Christian and Muslim Traditions. Saarbrucken, Germany: VDM Verlag.

Costecalde, Claude and John Paul Doherty (2012) Titanic Belfast. Holywood, Northern Ireland: Booklink.

Das, V. and A. Kleinman. (2000) Violence and Subjectivity. Berkley: University of California Press.

Davies, N. (1996) Europe: A History. New York: Harper Perennial Press. 
Discover Northern Ireland. "Welcome to the Mournes and Ring of Gullion" Accessed 10 October 2015.

https://www.discovernorthernireland.com/mournes/Welcome-to-the-Mournesand-Ring-of-Gullion-A3651

-----, "Peace Bridge". Accessed 11 July 2014.

http://www.discovernorthernireland.com/Peace-Bridge-Londonderry-DerryP23773

Dixon, Paul. (2001) Northern Ireland: The Politics of War and Peace. London: Palgrave.

Durkin, K. (2003) "Death, dying and the dead in popular culture" in C. Bryant (ed.) The Handbook of Death and Dying (pp. 43-49). New York: Sage.

Farmaki, A. (2013) "Dark tourism revisited: a supply/demand conceptualization" in International Journal of Culture, Tourism and Hospitality Research 7(3):281-292.

Fasick, Kevin, Leonard Greene and Danika Fears (2014) "Mixed response to 9/11 museum gift shop on opening day" in New York Post 22 May 2014. Accessed via New York Post facebook page on 22 May 2014. http://nypost.com/2014/05/22/gift- shop-inside-911-museum-draws-criticismon-opening-day/

Feldman A. (1991) Formations of Violence. Chicago: University of Chicago Press.

-----, (2000) "Violence and Vision: The Prosthetics and Aesthetics of Terror" in Violence and Subjectivity. Das, V and A. Kleinman (ed). pg: 46-78. Berkley: University of California Press.

Furlong, I. (2009) Irish Tourism 1880-1980. Dublin: Irish Academic Press.

Giddens, A. (1991) Modernity and Self Identity. Cambridge: Polity.

Global Site Plans: Branding for Environmental Design website. Accessed 17 June 2014. http://www.globalsiteplans.com/environmental-design/architectureenvironmental-design/can-architecture-resolve-conflict-the-legacy-of-northernirelands-peace-walls/

Green, E.R.R. (1949) The Lagan Valley 1800-1850: A Local History of the Industrial Revolution. London: Faber and Faber LTD

Harvey, D. (1996) "From Space, to Place and Back Again" in Justice, Nature and the Geography of Difference. Hoboken, NJ: Blackwell Publishers.

Hechter, M. (1975) Internal Colonialism. Berkley: University of California Press. 
Hennessey, T. (1997) A History of Northern Ireland. New York: St Martin's Press.

Ireland v. United Kingdom. European Court of Human Rights. 18 January 1978. Accessed 7 June 2015. http://www.worldlii.org/eu/cases/ECHR/1978/1.html

James, Simon (1999) The Atlantic Celts: Ancient People or Modern Invention?. Madison, WI: The University of Wisconsin Press.

Knox, D. (2006) "The sacralised landscapes of Glencoe: From massacre to mass tourism, and back again" in International Journal of Tourism Research 8(3):185-197.

Lennon, J. and Foley, M. (1996) "JFK and dark tourism: A fascination with assassination". International Journal of Heritage Studies (Taylor \& Francis) 2 (4): 198-211.

-----, (2000) Dark Tourism. New York: Continuum.

Lippard, L. R. (2000) On the Beaten Track: Tourism, Art and Place. New York: New Press.

MacCannell, D. (1989) The Tourist: A New Theory of the Leisure Class. New York: Schocken Books.

McLoughlin, Darren. (2014) "International Wall of Art on Belfast Peace Line is a Modern Day Berlin Wall" from Untapped Cities, 2 April 2014. Accessed 11 July 2014.

http://untappedcities.com/2014/04/02/international-wall-of-art-on-belfast-peaceline-is-a-modern-day-berlin-wall

Messenger, B. (1975) Picking Up the Linen Threads: A Study in Industrial Folklore. Austin, TX: University of Texas Press.

Mullan, K. (2013) "Catholics Outnumbered Protestants on Both Banks of the River Foyle" in Londonderry Sentinel, 31 January. Accessed 11 July 2014. http://www.londonderrysentinel.co.uk/news/community-news/catholicsoutnumber-protestants-on-both-banks-of-the-foyle-1-4737478

(NIAO) Northern Ireland Audit Office (2010) "Northern Ireland Tourist Board - Review of Signature Projects".

(NI Executive) Northern Ireland Executive (2007) "Programme for Government 20082011".

(NI Statistics) Northern Ireland Statistics and Research Agency (2015) "Northern Ireland Local Government District Tourism Statistics 2014". 
(NITB) Northern Ireland Tourist Board. (2003) “Tourism in Northern Ireland: A Strategic Framework for Action 2004-2007”.

-----, (2005) “Corporate Plan 2005-2008”.

-----, (2005) “Tourism Development Scheme 06/08”.

-----, (2007) "Northern Ireland Tourist Board Corporate Plan 2008-2011"

O’Neill, S. (2002) “Flood of Tourists Worsens Pain”. Daily Telegraph (27 Aug).

Rojek, C. 1993 Ways of Escape. Basingstoke: MacMillan.

Rolston, B. (1991) Politics and Painting: Murals and Conflict in Northern Ireland. Rutherford: Fairleigh Dickinson University Press.

-----, (1999) "Music and Politics in Ireland: The Case of Loyalism" in Politics and Performance in Contemporary Northern Ireland Harrington, J. P. and E. J. Mitchell (ed). Amherst, MA: University of Massachusetts Press.

Ruane, J. \& J. Todd (1996) The Dynamics of Conflict in Northern Ireland: Power, Conflict and Emancipation. Cambridge: University of Cambridge Press.

Rutherford, Adrian (2014) “Implement Belfast Telegraph's Ardoyne parade proposal, unionists urge" in Belfast Telegraph, 11 July 2014. Accessed via Belfast Telegraph newsstand app for iPad on 11 July 2014.

Sands, Bobby (1981) Bobby Sands: Writings from Prison. (CThe Bobby Sands Trust. Cork: Red Barn Publishing.

Seaton, A. V. (1996) "Guided by the dark: Thanatopsis to thanatourism" in International Journal of Heritage Studies 2(4):234-244.

Smith, A. (1776) The Wealth of Nations. New York: Penguin Books.

Spielvogel, J. J. (2009) Western Civilization Volume I: to 1715. Boston: Wadsworth CENGAGE Learning.

Stone, P. R. (2009) "Making Absent Death Present: Consuming Dark Tourism in Contemporary Society" in R Sharpley and P. R. Stone (ed.) The Darker Side of Travel: the Theory and Practice of Dark Tourism. Bristol: Channel View Publications.

Titanic Belfast website. Accessed 20 September 2014. http://www.titanicbelfast.com 
Turner, V. (1978) Image and Pilgrimage in Christian Culture. New York: Columbia University Press.

Ulster Museum website. Accessed 21 July 2014. http://www.nmni.com/um/Collections/Art-(1)

Ulster Museum. "Plantation to Power-sharing: The Troubles" Botanic Gardens, Belfast, County Antrim BT9 5AB, United Kingdom. 5 July 2013.

UNWTO website. Accessed 17 March 2015. http://media.unwto.org/en/content/understandingtourism-basic-glossary

Vallely, F (2008) Tuned Out: Traditional Music and Identity in Northern Ireland. Cork: Cork University Press.

Wallerstein, I. (2007) World Systems Analysis. Durham: Duke University Press.

Walter, T. (1991) “Modern death: Taboo or not taboo?” in Sociology 25: 293-310.

World War II Memorial website. Accessed 25 July 2014. http://www.nps.gov/wwii/historyculture/index.htm

Zuelow, E. G. E. (2009) Making Ireland Irish: Tourism and National Identity since the Irish Civil War. New York: Syracuse University Press. 
APPENDIX A

HERITAGE SITE TABLE

Note: Sites in red denote conflict site.

\begin{tabular}{|c|c|c|c|}
\hline Site Name & Location & Date & Notes \\
\hline $\begin{array}{l}\text { Theatre at the } \\
\text { Mill }\end{array}$ & $\begin{array}{l}\text { Carnmoney Road } \\
\text { Mort, Mossley } \\
\text { Mill, } \\
\text { Newtownabbey } \\
\text { BT36 5QA }\end{array}$ & $\begin{array}{l}1834 \text { - Linen Mill } \\
2010 \text { - Theatre }\end{array}$ & \\
\hline Carnmoney Hill & $\begin{array}{l}\text { Newtownabbey, } \\
\text { Newtownabbey } \\
\text { BT36 }\end{array}$ & $\begin{array}{l}\sim 500_{\mathrm{BCE}} \\
\text { Dunanney Rath }\end{array}$ & $\begin{array}{l}\text { Dunanney Rath (Fort) and } \\
\text { Carnmoney Cemetery share the } \\
\text { hill }\end{array}$ \\
\hline Roughtfort Motte & $\begin{array}{l}\text { Roughfort Rd, } \\
\text { Newtownabbey, } \\
\text { BT36 4RE }\end{array}$ & $\sim 800-1100$ & $\begin{array}{l}\text { Assembly site of the United } \\
\text { Irishmen } 1978\end{array}$ \\
\hline $\begin{array}{l}\text { Roughfort Liberty } \\
\text { Tree }\end{array}$ & $\begin{array}{l}\text { Roughfort Rd, } \\
\text { Newtownabbey, } \\
\text { BT36 4RE }\end{array}$ & $1790 \mathrm{~s}$ & $\begin{array}{l}\text { Oak tree dedicated to United } \\
\text { Irishmen }\end{array}$ \\
\hline $\begin{array}{l}\text { Ballynure Christ } \\
\text { Church \& } \\
\text { Graveyard }\end{array}$ & $\begin{array}{l}\text { Church Rd, } \\
\text { Ballynure, } \\
\text { Ballyclare BT39 } \\
\text { 9UF }\end{array}$ & $\begin{array}{l}2^{\text {nd }} \text { oldest cemetery } \\
\text { in Antrim }\end{array}$ & $\begin{array}{l}\text { Jonathan Swift served as } \\
\text { prebend at the church. }\end{array}$ \\
\hline $\begin{array}{l}\text { Ballyclare War } \\
\text { Memorial Park }\end{array}$ & $\begin{array}{l}\text { Ballyclare, } \\
\text { Newtownabbey, } \\
\text { BT39 9AF }\end{array}$ & $1920 \mathrm{~s}$ & WWI War Memorial \\
\hline The White House & $\begin{array}{l}34 \text { Whitehouse } \\
\text { Park, } \\
\text { Newtownabbey, } \\
\text { BT37 9SP }\end{array}$ & $1600 \mathrm{~s}$ & $\begin{array}{l}\text { Houses the Williamite and } \\
\text { Jacobite War exhibit }\end{array}$ \\
\hline $\begin{array}{l}\text { Rowan } \\
\text { Monument }\end{array}$ & $\begin{array}{l}\text { Station Rd, } \\
\text { Ballyclare BT39 } \\
\text { 0PE }\end{array}$ & & \\
\hline $\begin{array}{l}\text { Ballyrobert } \\
\text { Cottage Garden }\end{array}$ & $\begin{array}{l}154 \text { Ballyrobert } \\
\text { Road, Ballyclare, } \\
\text { BT39 9RT }\end{array}$ & & $\begin{array}{l}\text { Originally a small traditional } \\
\text { farm. Historical gardens. }\end{array}$ \\
\hline $\begin{array}{l}\text { George Best } \\
\text { House }\end{array}$ & $\begin{array}{l}16 \text { Burren Way, } \\
\text { Belfast } \\
\text { CAstleraegh BT6 } \\
\text { 0DW }\end{array}$ & $\begin{array}{l}2011-\text { as a tourist } \\
\text { site }\end{array}$ & $\begin{array}{l}\text { Visitors can rent the home of } \\
\text { footballer George Best }\end{array}$ \\
\hline Schomberg House & $\begin{array}{l}368 \text { Cregagh } \\
\text { Road, Belfast BT6 } \\
\text { 9YE }\end{array}$ & 2001 - museum & $\begin{array}{l}\text { Museum of Orange Heritage } \\
\text { Stop on George Best Trail }\end{array}$ \\
\hline
\end{tabular}




\begin{tabular}{|c|c|c|c|}
\hline $\begin{array}{l}\text { Cregagh Playing } \\
\text { Field \& George } \\
\text { Best Mural } \\
\end{array}$ & $\begin{array}{l}\text { Cregagh Road, } \\
\text { Belfast }\end{array}$ & & Stop on George Best Trail \\
\hline $\begin{array}{l}\text { Bells Bridge } \\
\text { Roundabout }\end{array}$ & $\begin{array}{l}\text { Cregagh Road, } \\
\text { Mayfair Ave, } \\
\text { Ladas Dr, Mount } \\
\text { Merrion Ave }\end{array}$ & & $\begin{array}{l}\text { Irish Football Association logo } \\
\text { planted in the roundabout } \\
\text { Stop on George Best Trail }\end{array}$ \\
\hline $\begin{array}{l}\text { Ambassador } \\
\text { Cinema }\end{array}$ & $\begin{array}{l}29 \text { Cregagh Road, } \\
\text { Belfast BT6 8PX }\end{array}$ & $\begin{array}{l}1936-\text { opened } \\
1972-\text { cinema } \\
\text { closed }\end{array}$ & $\begin{array}{l}\text { Stop on George Best Trail } \\
\text { Now a Wyse Byse department } \\
\text { store }\end{array}$ \\
\hline Donard Street & & & Stop on George Best Trail \\
\hline $\begin{array}{l}\text { Ravenhill } \\
\text { Presbyterian } \\
\text { Chruch }\end{array}$ & $\begin{array}{l}\text { 244 Ravenhill } \\
\text { Road, Belfast, } \\
\text { BT6 8EF }\end{array}$ & & Stop on George Best Trail \\
\hline $\begin{array}{l}\text { Spence's Chip } \\
\text { Shop }\end{array}$ & $\begin{array}{l}\text { Beersbridge Road, } \\
\text { Belfast BT5 4RW }\end{array}$ & 1921 & Stop on George Best Trail \\
\hline $\begin{array}{l}\text { Desano's Ice } \\
\text { Cream Parlour }\end{array}$ & $\begin{array}{l}344 \text { Newtownards } \\
\text { Road, Belfast, } \\
\text { BT4 1HE }\end{array}$ & & Stop on George Best Trail \\
\hline The Oval & $\begin{array}{l}\text { Parkgate Dr, } \\
\text { Belfast, BT4 1EW }\end{array}$ & 1892 & $\begin{array}{l}\text { Glentoran Football Club's } \\
\text { stadium } \\
\text { Stop on George Best Trail }\end{array}$ \\
\hline $\begin{array}{l}\text { George Best } \\
\text { Grave }\end{array}$ & $\begin{array}{l}\text { Roselawn } \\
\text { Cemetery } \\
127 \text { Ballygowan } \\
\text { Road, } \\
\text { Crossnacreevy, } \\
\text { Belfast, } \\
\text { Castlereagh BT5 } \\
\text { 7Tz }\end{array}$ & 2005 & $\begin{array}{l}\text { Stop on George Best Trail } \\
\text { Gravesite: S295 }\end{array}$ \\
\hline Belfast Castle & $\begin{array}{l}\text { Antrim Road, } \\
\text { Belfast, Antrim } \\
\text { BT15 5GR }\end{array}$ & $\begin{array}{l}1870 \\
1934-\text { given to } \\
\text { City of Belfast } \\
1988-\text { opened to } \\
\text { public }\end{array}$ & $\begin{array}{l}\text { Home to Baron Chichester, } \\
\text { later Earl of Shaftesbury } \\
\text { purchased from Baron. }\end{array}$ \\
\hline $\begin{array}{l}\text { Cavehill Country } \\
\text { Park }\end{array}$ & $\begin{array}{l}\text { Antrim Road, } \\
\text { Belfast BT15 5GR }\end{array}$ & & $\begin{array}{l}\text { Napoleon's Nose believed to } \\
\text { be inspiration for Jonathan } \\
\text { Swift's Gulliver's Travels } \\
\text { Archeological sites including } \\
\text { McArts Fort }\end{array}$ \\
\hline Malone House & $\begin{array}{l}\text { Barnett Demesne, } \\
\text { Belfast BT9 5PB }\end{array}$ & $\begin{array}{l}1820 \text { s } \\
1946 \text { - given to } \\
\text { City of Belfast } \\
1983-\text { opened to } \\
\text { public }\end{array}$ & $\begin{array}{l}17^{\text {th }} \text { century fort site } \\
\text { Home of merchant William } \\
\text { Wallace Legge }\end{array}$ \\
\hline
\end{tabular}




\begin{tabular}{|c|c|c|c|}
\hline Titanic Belfast & $\begin{array}{l}1 \text { Olympic Way, } \\
\text { Belfast BT3 9EP }\end{array}$ & 2012 & $\begin{array}{l}\text { An interactive museum } \\
\text { dedicated to the building of the } \\
\text { Titanic and her sister ships } \\
\text { Stop on Titanic Discovery } \\
\text { Tour } \\
\text { One of NITB's Signature } \\
\text { Projects. } \\
\text { The Titanic slipways are } \\
\text { located on this site. }\end{array}$ \\
\hline $\begin{array}{l}\text { Harland \& Wolff } \\
\text { shipyard }\end{array}$ & $\begin{array}{l}\text { Queens Island, } \\
\text { Belfast BT3 9UD }\end{array}$ & 1861 & $\begin{array}{l}\text { Home of cranes Samson } \\
\text { (1974) and Goliath (1969) - } \\
\text { listed as historic monuments }\end{array}$ \\
\hline $\begin{array}{l}\text { Harland \& Wolff } \\
\text { Headquarters and } \\
\text { Drawing Offices }\end{array}$ & $\begin{array}{l}2 \text { Queens Road, } \\
\text { Belfast BT3 9DT }\end{array}$ & $\begin{array}{l}1919-1989- \\
\text { active } \\
2012-\text { open to the } \\
\text { public }\end{array}$ & $\begin{array}{l}\text { Stop on Titanic Belfast } \\
\text { Discovery Tour } \\
\text { Stop on The Yardmen Trail } \\
\text { Owned by Titanic Quarter Ltd }\end{array}$ \\
\hline $\begin{array}{l}\text { Hamilton Graving } \\
\text { Dock \& SS } \\
\text { Nomadic }\end{array}$ & $\begin{array}{l}\text { Queens Road, } \\
\text { Belfast BT3 9DT }\end{array}$ & $\begin{array}{l}1860 \mathrm{~s} \\
2012-\text { open to } \\
\text { public }\end{array}$ & $\begin{array}{l}\text { Stop on Titanic Belfast } \\
\text { Discovery Tour } \\
\text { Stop on The Yardmen Trail }\end{array}$ \\
\hline $\begin{array}{l}\text { PRONI - Public } \\
\text { Records Office } \\
\text { Northern Ireland }\end{array}$ & $\begin{array}{l}2 \text { Titanic } \\
\text { Boulevard, Titanic } \\
\text { Quarter, Belfast, } \\
\text { Antrim BT3 9HQ }\end{array}$ & Established 1923 & $\begin{array}{l}\text { Visitors are encouraged to } \\
\text { search for family records and } \\
\text { other historical documents } \\
\text { dating to } 1921\end{array}$ \\
\hline $\begin{array}{l}\text { Ship of Dreams } \\
\text { Mural }\end{array}$ & $\begin{array}{l}74 \text { Newtownards } \\
\text { Road, Belfast BT4 } \\
\text { 1GN }\end{array}$ & June 2010 & $\begin{array}{l}\text { Mural dedicated to Titanic and } \\
\text { the shipbuilding legacy of } \\
\text { Belfast } \\
\text { Stop on The Yardmen Trail }\end{array}$ \\
\hline The Yardmen & $\begin{array}{l}\text { Newtownards } \\
\text { Road, Belfast BT4 } \\
\text { 1BU }\end{array}$ & March 2012 & $\begin{array}{l}\text { Bronze statues of shipyard } \\
\text { workers } \\
\text { Stop on The Yardmen Trail } \\
\text { Located at an entrance to Dr } \\
\text { Pitt Memorial Park }\end{array}$ \\
\hline $\begin{array}{l}\text { Dr Pitt Memorial } \\
\text { Park }\end{array}$ & $\begin{array}{l}\text { Newtownards } \\
\text { Road, Belfast BT4 } \\
\text { 1BU }\end{array}$ & & $\begin{array}{l}\text { Stop on The Yardmen Trail } \\
\text { Park is located on old walkway } \\
\text { for Shipyard workers }\end{array}$ \\
\hline $\begin{array}{l}\text { Westbourne } \\
\text { Presbyterian } \\
\text { Church }\end{array}$ & $\begin{array}{l}149 \text { Newtownards } \\
\text { Road, Belfast BT4 } \\
\text { 1AB }\end{array}$ & 1880 & $\begin{array}{l}\text { Stop on The Yardmen Trail } \\
\text { Called The Shipyard Church } \\
\text { Where many shipyard workers } \\
\text { and their families worshipped }\end{array}$ \\
\hline $\begin{array}{l}\text { Templemore } \\
\text { Public Baths }\end{array}$ & $\begin{array}{l}\text { Templemore Ave, } \\
\text { Belfast BT5 4FW }\end{array}$ & 1893 & $\begin{array}{l}\text { Stop on The Yardmen Trail } \\
\text { Public bathhouse frequented by } \\
\text { shipyard workers and other } \\
\text { famous faces of Belfast } \\
\text { including George Best, Van } \\
\text { Morrison and C. S. Lewis }\end{array}$ \\
\hline McMaster Street & Belfast BT5 4HP & $1898-1908$ built & Stop on The Yardmen Trail \\
\hline
\end{tabular}




\begin{tabular}{|c|c|c|c|}
\hline & & & $\begin{array}{l}\text { Terrace houses shipyard } \\
\text { workers lived in }\end{array}$ \\
\hline $\begin{array}{l}\text { The Great Eastern } \\
\text { Bar }\end{array}$ & $\begin{array}{l}273 \text { Newtownards } \\
\text { Road, Belfast BT4 } \\
\text { 1AF }\end{array}$ & $1880 \mathrm{~s}$ & $\begin{array}{l}\text { Stop on The Yardmen Trails } \\
\text { Named after the ship the Great } \\
\text { Eastern } \\
\text { Originally built by John } \\
\text { McKenna founder of Liverpool } \\
\text { Football Club }\end{array}$ \\
\hline $\begin{array}{l}\text { Dee Street Titanic } \\
\text { Mural }\end{array}$ & $\begin{array}{l}12 \text { Dee Street, } \\
\text { Belfast BT4 1FT }\end{array}$ & & $\begin{array}{l}\text { Stop on The Yardmen Trail } \\
\text { Mural dedicated to Titanic, } \\
\text { White Star Line and Harland \& } \\
\text { Wolff }\end{array}$ \\
\hline $\begin{array}{l}\text { Titanic Dock \& } \\
\text { Pump-House }\end{array}$ & $\begin{array}{l}\text { NI Science Park, } \\
\text { Queen's Road, } \\
\text { Queen's Island, } \\
\text { Belfast BT3 9DT }\end{array}$ & $\begin{array}{l}1904-\text { pump } \\
\text { house } \\
1911-\text { Thompson } \\
\text { dock }\end{array}$ & $\begin{array}{l}\text { Thompson graving dock's first } \\
\text { ship was the Olympic } \\
\text { Stop on Titanic Discovery } \\
\text { Tour } \\
\text { Includes the Pump House café } \\
\text { and Visitor Centre. }\end{array}$ \\
\hline $\begin{array}{l}\text { Alexandra } \\
\text { Dock/HMS } \\
\text { Caroline }\end{array}$ & $\begin{array}{l}\text { Queens Road, } \\
\text { Belfast BT3 9DT }\end{array}$ & 1914 & $\begin{array}{l}\text { Museum ship - } \\
\text { decommissioned WWI Royal } \\
\text { Navy light cruiser }\end{array}$ \\
\hline Belfast Barge & $\begin{array}{l}1 \text { Lanyon Quay, } \\
\text { Belfast BT1 3LG }\end{array}$ & 2002 & $\begin{array}{l}\text { Maritime themed visitors } \\
\text { attraction } \\
\text { Home of Lagan Legacy - } \\
\text { floating museum of Belfast's } \\
\text { industrial and maritime eras }\end{array}$ \\
\hline Clarendon Docks & Belfast BT3, 9AH & 1796 & $\begin{array}{l}\text { Dry docks that housed one of } \\
\text { the first shipbuilding } \\
\text { companies in Belfast. Was } \\
\text { used from } 1796 \text { to } 1960 \mathrm{~s} \text {. }\end{array}$ \\
\hline $\begin{array}{l}\text { Sinclair Seamen's } \\
\text { Presbyterian } \\
\text { Church }\end{array}$ & $\begin{array}{l}\text { Corporation } \\
\text { Square, Belfast, } \\
\text { BT1 3AJ }\end{array}$ & 1857 & $\begin{array}{l}\text { Venetian harbourside church. } \\
\text { Features HMS Hood's bell and } \\
\text { lifeboat shaped collection } \\
\text { boxes and a nautical theme. }\end{array}$ \\
\hline $\begin{array}{l}\text { Harbour } \\
\text { Comissioner's } \\
\text { Office }\end{array}$ & $\begin{array}{l}\text { Corporation } \\
\text { Square, Belfast, } \\
\text { BT1 3AL }\end{array}$ & & Victorian architecture \\
\hline Lagan Lookout & $\begin{array}{l}1 \text { Donegall Quay, } \\
\text { Belfast, BT1 3EA }\end{array}$ & 1994 & $\begin{array}{l}\text { Visitor Centre that explains the } \\
\text { history and function of the } \\
\text { Lagan Weir. The Big Fish art } \\
\text { installation is featured here. }\end{array}$ \\
\hline McHugh's & $\begin{array}{l}\text { 29-31 Queens } \\
\text { Square, Belfast } \\
\text { BT1 3FG }\end{array}$ & 1711 & $\begin{array}{l}\text { Oldest surviving building in } \\
\text { Belfast }\end{array}$ \\
\hline
\end{tabular}




\begin{tabular}{|c|c|c|c|}
\hline White's Tavern & $\begin{array}{l}\text { 2-4 Winecellar } \\
\text { Entry, Belfast } \\
\text { BT1 1 QN }\end{array}$ & 1630 & Belfast's oldest tavern \\
\hline The Botanic Inn & $\begin{array}{l}\text { 23-27 Malone Rd, } \\
\text { Belfast BT9 6UR }\end{array}$ & 1867 & $\begin{array}{l}\text { Example of Victorian } \\
\text { architecture } \\
\text { Known as 'The Bot' }\end{array}$ \\
\hline $\begin{array}{l}\text { St Anne's } \\
\text { Cathedral }\end{array}$ & $\begin{array}{l}\text { Donegall Street, } \\
\text { Belfast, BT12 } 2 \\
\text { HB }\end{array}$ & 1904 & $\begin{array}{l}\text { Protestant church } \\
\text { Serves two dioceses: Connor } \\
\text { and Down \& Dromore } \\
\text { Also known as Belfast } \\
\text { Cathedral }\end{array}$ \\
\hline $\begin{array}{l}\text { Northern Ireland } \\
\text { War Memorial }\end{array}$ & $\begin{array}{l}21 \text { Talbot Street, } \\
\text { Belfast BT1 2LD }\end{array}$ & 2007 & $\begin{array}{l}\text { Memorial to WWI \& WWII } \\
\text { veterans, } 1941 \text { Belfast Blitz } \\
\text { victims and the US forces who } \\
\text { trained in Belfast from } 1942 \text { to } \\
1945\end{array}$ \\
\hline $\begin{array}{l}\text { Albert Memorial } \\
\text { Clock }\end{array}$ & $\begin{array}{l}\text { Queens Square, } \\
\text { Belfast BT1 3FF }\end{array}$ & 1870 & $\begin{array}{l}\text { Memorial to Prince Consort, } \\
\text { Albert } \\
\text { Designed by W. J. Barre } \\
\text { Damaged in PIRA bombing of } \\
\text { River House in High Street } \\
\text { January } 1992 \\
\text { Restoration began in } 2002 \text { to } \\
\text { halt the tower's lean }\end{array}$ \\
\hline $\begin{array}{l}\text { Customs House } \\
\text { Square }\end{array}$ & Belfast BT1 2DY & $1800 \mathrm{~s}$ & $\begin{array}{l}\text { Designed by Charles Lanyon } \\
\text { The steps were popular with } \\
\text { orators in the } 19^{\text {th }} \text { and } 20^{\text {th }} \\
\text { centuries } \\
\text { Outdoor Music venue today }\end{array}$ \\
\hline $\begin{array}{l}\text { Golden Thread } \\
\text { Gallery }\end{array}$ & $\begin{array}{l}\text { 84-94 Great } \\
\text { Patrick Street, } \\
\text { Belfast, BT1 2LU }\end{array}$ & 1998 & $\begin{array}{l}\text { Contemporary art gallery } \\
\text { established in a former linen } \\
\text { mill. }\end{array}$ \\
\hline The MAC & $\begin{array}{l}10 \text { Exchange } \\
\text { Street West, } \\
\text { Belfast, BT1 2NJ }\end{array}$ & 2012 & $\begin{array}{l}\text { Metropolitan Arts Centre. } \\
\text { Features } 2 \text { theatres and art } \\
\text { galleries. }\end{array}$ \\
\hline $\begin{array}{l}\text { Belfast Central } \\
\text { Library }\end{array}$ & $\begin{array}{l}126 \text { Royal } \\
\text { Avenue, Belfast, } \\
\text { BT1 1EA }\end{array}$ & 1888 & $\begin{array}{l}\text { Part of the Libraries NI } \\
\text { network and houses the largest } \\
\text { newspaper collection in } \\
\text { Northern Ireland and other } \\
\text { heritage resources. }\end{array}$ \\
\hline $\begin{array}{l}\text { Titanic Pub \& } \\
\text { Kitchen }\end{array}$ & $\begin{array}{l}\text { 2-14 Little } \\
\text { Donegall Street, } \\
\text { Belfast, BT1 2JD }\end{array}$ & & $\begin{array}{l}\text { Edwardian style pub in the } \\
\text { refurbished Robert Watson \& } \\
\text { Co furniture factory, a } \\
\text { furnishing contractor for White } \\
\text { Star Line. }\end{array}$ \\
\hline
\end{tabular}




\begin{tabular}{|c|c|c|c|}
\hline CastleCourt & $\begin{array}{l}\text { Royal Avenue, } \\
\text { Belfast BT1 1DD }\end{array}$ & Late 1980s & $\begin{array}{l}3^{\text {rd }} \text { largest shopping centre in } \\
\text { Northern Ireland. Has been a } \\
\text { target of PIRA bomb attacks } \\
\text { since its construction. }\end{array}$ \\
\hline Victoria's Square & $\begin{array}{l}1 \text { Victoria Square, } \\
\text { Belfast BT1 4QG }\end{array}$ & $\begin{array}{l}1870 \\
2008-\text { Shopping } \\
\text { Centre constructed }\end{array}$ & $\begin{array}{l}\text { Jaffe Fountain remains on } \\
\text { original site } \\
\text { Shopping centre built } 2008 \\
\text { Chichester Street property is } \\
\text { built on top of old J B } \\
\text { Ferguson \& Co Automobile } \\
\text { Engineers } 1907 \text { expansion } \\
\text { Stop on Harry Ferguson Trail }\end{array}$ \\
\hline $\begin{array}{l}\text { Rosemary Street } \\
\text { Third } \\
\text { Presbyterian } \\
\text { Church / Masonic } \\
\text { Provincial Grand } \\
\text { Lodge of Antrim }\end{array}$ & $\begin{array}{l}\text { Rosemary Street, } \\
\text { Belfast, BT1 1QA }\end{array}$ & $\begin{array}{l}1722 \\
\text { Destroyed in } 1941 \\
\text { Blitz attack } \\
1954 \text { - Masonic } \\
\text { Hall }\end{array}$ & $\begin{array}{l}\text { Radical congregation that } \\
\text { played a role in The United } \\
\text { Irishmen Rebellion. Henry Joy } \\
\text { McCracken a leader in the } \\
\text { rebellion was a member of the } \\
\text { congregation and lived across } \\
\text { the street. } \\
\text { The building was destroyed in } \\
1941 \text { during a German Blitz } \\
\text { attack and replaced by the } \\
\text { Masonic building. The } \\
\text { building has a commemorative } \\
\text { plaque to McCracken. }\end{array}$ \\
\hline $\begin{array}{l}\text { St George's } \\
\text { Church }\end{array}$ & & $\begin{array}{l}1306 \text { - original } \\
\text { chapel } \\
1816 \text { - present } \\
\text { church built }\end{array}$ & $\begin{array}{l}\text { Oldest Church of Ireland in } \\
\text { Belfast. William of Orange } \\
\text { attended the Arise Great King } \\
\text { sermon at the original church. } \\
\text { The second church built on the } \\
\text { site was targeted during the } \\
\text { Troubles by the PIRA. }\end{array}$ \\
\hline Spirit of Belfast & $\begin{array}{l}\text { Arthur Square, } \\
\text { Belfast }\end{array}$ & September 2009 & $\begin{array}{l}\text { The sculpture represents the } \\
\text { linen and shipbuilding } \\
\text { industries in Belfast. }\end{array}$ \\
\hline $\begin{array}{l}\text { Harry Ferguson } \\
\text { Motors }\end{array}$ & $\begin{array}{l}\text { 11-16 Donegall } \\
\text { Square East, } \\
\text { Belfast BT1 5UB }\end{array}$ & & $\begin{array}{l}\text { Stop on Harry Ferguson Trail } \\
\text { Showroom building remains } \\
\text { and is occupied by the Ulster } \\
\text { Bank }\end{array}$ \\
\hline Belfast City Hall & $\begin{array}{l}\text { Donegall Square, } \\
\text { Belfast, Antrim } \\
\text { BT1 5GS }\end{array}$ & 1906 & $\begin{array}{l}\text { Building built on the site of } \\
\text { White Linen Hall, an } \\
\text { international Linen Exchange } \\
\text { The gardens house various } \\
\text { memorials }\end{array}$ \\
\hline
\end{tabular}




\begin{tabular}{|c|c|c|c|}
\hline $\begin{array}{l}\text { Garden of } \\
\text { Remembrance }\end{array}$ & City Hall & & $\begin{array}{l}\text { Northern Ireland's main war } \\
\text { memorial }\end{array}$ \\
\hline Titanic Memorial & City Hall & & \\
\hline $\begin{array}{l}\text { Linen Hall } \\
\text { Library }\end{array}$ & $\begin{array}{l}17 \text { Donegall } \\
\text { Square, Belfast } \\
\text { BT1 5GB }\end{array}$ & 1788 & $\begin{array}{l}\text { Oldest library in Belfast. } \\
\text { Houses the Irish and Local } \\
\text { Studies, CS Lewis, and } \\
\text { Northern Ireland Political } \\
\text { Collections. }\end{array}$ \\
\hline $\begin{array}{l}\text { St George's } \\
\text { Market }\end{array}$ & $\begin{array}{l}\text { 12-20 Est Bridge } \\
\text { Street, Belfast } \\
\text { BT1 3NQ }\end{array}$ & $\begin{array}{l}1604-\text { market } \\
\text { opens } \\
1896 \text { - present } \\
\text { market completed }\end{array}$ & $\begin{array}{l}\text { St George's has hosted a } \\
\text { Friday market on the site since } \\
1604\end{array}$ \\
\hline $\begin{array}{l}\text { Belfast Visitors } \\
\text { Centre }\end{array}$ & $\begin{array}{l}9 \text { Donegall Square } \\
\text { North, Belfast } \\
\text { BT1 5GJ }\end{array}$ & & $\begin{array}{l}\text { Visit Belfast headquarters } \\
\text { Gift Shop } \\
\text { Tourist information centre }\end{array}$ \\
\hline $\begin{array}{l}\text { J B Ferguson \& } \\
\text { Co. Automobile } \\
\text { Engineers }\end{array}$ & $\begin{array}{l}\text { 41 Little Donegall } \\
\text { St, Belfast BT1 }\end{array}$ & 1903 & $\begin{array}{l}\text { Stop on Harry Ferguson Trail } \\
\text { Redevelopment has left no } \\
\text { trace of original buildings }\end{array}$ \\
\hline Waterfront Hall & $\begin{array}{l}2 \text { Lanyon Place, } \\
\text { Belfast, BT1 3WH }\end{array}$ & 1997 & $\begin{array}{l}\text { Key venue for Ulster Orchestra } \\
\text { and Belfast Festival at } \\
\text { Queen's. Multi-purpose } \\
\text { facility. } \\
\text { Architectural sight-seeing site } \\
\text { and Events venue. }\end{array}$ \\
\hline $\begin{array}{l}\text { Beacon of Hope / } \\
\text { Ring of } \\
\text { Thanksgiving }\end{array}$ & $\begin{array}{l}\text { Thanksgiving } \\
\text { Square, Oxford } \\
\text { Street, Belfast } \\
\text { BT2 7BB }\end{array}$ & 2007 & $\begin{array}{l}2^{\text {nd }} \text { largest public sculpture in } \\
\text { Belfast. Inspired by Thanks- } \\
\text { Giving Square in Dallas, TX. } \\
\text { Symbolizes peace, } \\
\text { thanksgiving and harmony. } \\
\text { The sculpture is used as the } \\
\text { symbol and logo for Belfast by } \\
\text { the Belfast City Council, NITB } \\
\text { and Visit Belfast and various } \\
\text { other agencies for the } \\
\text { promotion of the city. }\end{array}$ \\
\hline Europa Hotel & $\begin{array}{l}\text { Great Victoria } \\
\text { Street, Belfast } \\
\text { BT2 7AP }\end{array}$ & 1971 & $\begin{array}{l}\text { Most bombed hotel in the } \\
\text { world } \\
28 \text { bombings from } 1970 \text { to } \\
1999\end{array}$ \\
\hline Ulster Hall & $\begin{array}{l}34 \text { Bedford St, } \\
\text { Belfast BT2 7FF }\end{array}$ & 1862 & $\begin{array}{l}\text { Designed by W. J. Barre } \\
\text { Concert hall } \\
\text { Houses one of the oldest } \\
\text { functioning classic English } \\
\text { pipe organ - Mullholland } \\
\text { Grand Organ }\end{array}$ \\
\hline
\end{tabular}




\begin{tabular}{|c|c|c|c|}
\hline & & & $\begin{array}{l}\text { Joseph Carey's Belfast scenes } \\
-13 \text { paintings of historical } \\
\text { scenes of Belfast } 1902\end{array}$ \\
\hline $\begin{array}{l}\text { St Malachy's } \\
\text { Church }\end{array}$ & $\begin{array}{l}24 \text { Alfred Street, } \\
\text { Belfast, BT2 8EN }\end{array}$ & 1841-1844 & $\begin{array}{l}3^{\text {rd }} \text { oldest Catholic Church in } \\
\text { Belfast. Damaged during the } \\
\text { Belfast Blitz 1941. }\end{array}$ \\
\hline $\begin{array}{l}\text { Grand Opera } \\
\text { House }\end{array}$ & $\begin{array}{l}\text { 2-4 Great Victoria } \\
\text { St, Belfast BT2 } \\
\text { 7HR }\end{array}$ & $\begin{array}{l}1895 \\
1980 \text {-reopening } \\
2006 \text { - renovations }\end{array}$ & $\begin{array}{l}\text { Closed in } 1972 \text { when the } \\
\text { economy was affected by the } \\
\text { Troubles } \\
\text { Damaged by blasts from } \\
\text { Europa bombings during 1990s }\end{array}$ \\
\hline $\begin{array}{l}\text { Streamvale Open } \\
\text { Farm }\end{array}$ & $\begin{array}{l}38 \text { Ballyhanwood } \\
\text { Road, Dundonald, } \\
\text { Belfast, County } \\
\text { Down, BT5 7SN }\end{array}$ & $\begin{array}{l}\text { Open to public in } \\
\text { late } 1980 \text { s }\end{array}$ & Dairy Farm open to the public. \\
\hline Ormeau Park & $\begin{array}{l}\text { Ormeau Road, } \\
\text { Belfast, BT7 3GG }\end{array}$ & 1871 & $\begin{array}{l}\text { Oldest municipal park in } \\
\text { Belfast } \\
\text { Used for Orange Order } \\
\text { gatherings } \\
\text { First meeting of Ulster } \\
\text { Vanguard held in the park } 18 \\
\text { March } 1972 \text { - William Craig } \\
\text { gave his controversial speech } \\
\text { during the meeting, in which } \\
\text { he called for the careful } \\
\text { compilation of names of 'the } \\
\text { enemy' for future eradication }\end{array}$ \\
\hline $\begin{array}{l}\text { Queens } \\
\text { University Belfast }\end{array}$ & $\begin{array}{l}\text { University Road, } \\
\text { Belfast BT7 1NN }\end{array}$ & 1845 & $\begin{array}{l}\text { Main building designed by } \\
\text { Charles Lanyon }\end{array}$ \\
\hline Botanic Gardens & $\begin{array}{l}\text { College Park, } \\
\text { Botanic Ave, } \\
\text { Belfast BT7 1LP }\end{array}$ & $\begin{array}{l}1828 \\
1830-\text { Palm } \\
\text { House }\end{array}$ & $\begin{array}{l}\text { Home of the Rose Gardens and } \\
\text { Palm House } \\
\text { Palm House designed by } \\
\text { Charles Lanyon }\end{array}$ \\
\hline Ulster Museum & $\begin{array}{l}\text { Botanic Gardens, } \\
\text { Belfast BT9 5AB }\end{array}$ & $\begin{array}{l}1929 \\
2009-\text { reopened } \\
\text { following } \\
\text { renovations }\end{array}$ & $\begin{array}{l}\text { Collections in art and fashion, } \\
\text { natural science and history } \\
\text { Troubles Exhibit in History } \\
\text { Zone } \\
\text { Listed on National Museums } \\
\text { of Northern Ireland }\end{array}$ \\
\hline Lyric Theatre & $\begin{array}{l}\text { 55 Ridgeway } \\
\text { Street, Belfast, } \\
\text { BT9 5FB }\end{array}$ & 1951 & $\begin{array}{l}\text { Was the meeting site of Queen } \\
\text { Elizabeth II, Martin } \\
\text { McGuinness and a former } \\
\text { commander of the IRA. }\end{array}$ \\
\hline Beatrice Kennedy & $\begin{array}{l}44 \text { University } \\
\text { Road, Belfast BT7 } \\
\text { 1NJ }\end{array}$ & $\begin{array}{l}1860 \text { s } \\
1996 \text { - restaurant }\end{array}$ & $\begin{array}{l}\text { The house was built in the late } \\
19^{\text {th }} \text { century }\end{array}$ \\
\hline
\end{tabular}




\begin{tabular}{|c|c|c|c|}
\hline & & & $\begin{array}{l}\text { Once home of BBC NI } \\
\text { presenter Wendy Austin } \\
\text { Restaurant }\end{array}$ \\
\hline The Gasworks & $\begin{array}{l}\text { Ormeau Avenue, } \\
\text { Belfast BT7 2JB }\end{array}$ & 1893 & $\begin{array}{l}\text { Provided gas to city of Belfast } \\
\text { for } 160 \text { years. The Profits } \\
\text { made from the Gasworks built } \\
\text { City Hall. Now an Office Park. }\end{array}$ \\
\hline Stormont Estate & $\begin{array}{l}\text { Upper } \\
\text { Newtonwards } \\
\text { Road, Belfast BT4 } \\
\text { 3XX }\end{array}$ & & $\begin{array}{l}\text { Houses Northern Ireland's } \\
\text { main government buildings }\end{array}$ \\
\hline $\begin{array}{l}\text { Stormont } \\
\text { Parliament } \\
\text { Buildings }\end{array}$ & Stormont Estate & 1932 & $\begin{array}{l}\text { Seat of the Northern Ireland } \\
\text { Assembly } \\
\text { Formally housed Parliament of } \\
\text { Northern Ireland }\end{array}$ \\
\hline $\begin{array}{l}\text { Crumlin Road } \\
\text { Gaol }\end{array}$ & $\begin{array}{l}\text { 53-55 Crumlin } \\
\text { Road, Belfast } \\
\text { BT14 6ST }\end{array}$ & $\begin{array}{l}1845 \\
1996-\text { closed as a } \\
\text { jail }\end{array}$ & $\begin{array}{l}\text { Designed by Charles Lanyon } \\
\text { Over } 150 \text { years over } 25,000 \\
\text { people were imprisoned in the } \\
\text { complex including murderers, } \\
\text { suffragettes, loyalist and } \\
\text { republican prisoners. } \\
17 \text { executions took place on the } \\
\text { site }\end{array}$ \\
\hline Shankill Murals & $\begin{array}{l}\text { Shankill } \\
\text { neighborhood }\end{array}$ & & $\begin{array}{l}\text { Protestant and Unionist murals } \\
\text { displayed on the sides of } \\
\text { housing estates }\end{array}$ \\
\hline $\begin{array}{l}\text { The Spectrum } \\
\text { Centre }\end{array}$ & $\begin{array}{l}\text { 331-333 Shankill } \\
\text { Road, Belfast } \\
\text { BT13 3AA }\end{array}$ & 2001 & $\begin{array}{l}\text { Multi-purpose arts centre } \\
\text { Tourist Information Centre for } \\
\text { Shankill neighborhood }\end{array}$ \\
\hline $\begin{array}{l}\text { The Mill at } \\
\text { Conway Street }\end{array}$ & $\begin{array}{l}\text { 5-7 Conway } \\
\text { Street, Belfast } \\
\text { BT13 } 2 \text { DE }\end{array}$ & 1842 & $\begin{array}{l}\text { Began as a flax spinning mill } \\
\text { Troubles museum located on } \\
\text { the complex } \\
\text { Shopping centre }\end{array}$ \\
\hline $\begin{array}{l}\text { Shankill } \\
\text { Memorial Park }\end{array}$ & $\begin{array}{l}\text { Shankill Road, } \\
\text { Belfast BT13 }\end{array}$ & & $\begin{array}{l}\text { Dedicated to those from the } \\
\text { area who served in both World } \\
\text { Wars and 'subsequent } \\
\text { conflicts' } \\
\text { Bomb Memorial to those killed } \\
\text { in the Shankill bombing in } \\
1993\end{array}$ \\
\hline $\begin{array}{l}\text { Hamilton } \\
\text { Partnership }\end{array}$ & $\begin{array}{l}75 \text { Shankill Rd, } \\
\text { Belfast BT13 1DY }\end{array}$ & & $\begin{array}{l}\text { Stop on Harry Ferguson Trail } \\
\text { Original building and business } \\
\text { no longer exists - now Shankill } \\
\text { Gospel Hall }\end{array}$ \\
\hline $\begin{array}{l}\text { St Peters } \\
\text { Cathedral }\end{array}$ & $\begin{array}{l}\text { St Peter's Square, } \\
\text { Belfast BT12 4BU }\end{array}$ & 1866 & $\begin{array}{l}\text { Seat of Roman Catholic } \\
\text { Bishop of Down and Connor }\end{array}$ \\
\hline
\end{tabular}




\begin{tabular}{|c|c|c|c|}
\hline Falls Murals & $\begin{array}{l}\text { Falls } \\
\text { neighborhood }\end{array}$ & & $\begin{array}{l}\text { Nationalists murals displayed } \\
\text { on the sides of housing estates } \\
\text { and shops }\end{array}$ \\
\hline $\begin{array}{l}\text { International Wall } \\
\& \text { Peace Lines }\end{array}$ & $\begin{array}{l}\text { Lanark Way \& } \\
\text { Cupar Way, } \\
\text { Belfast }\end{array}$ & 1971 & $\begin{array}{l}\text { A portion of the peace line } \\
\text { with murals invoking solidarity } \\
\text { with other groups involved in } \\
\text { nationalist struggles - } \\
\text { Palestine, Basque, American } \\
\text { civil rights movement } \\
\text { Signature/Message Wall } \\
\text { includes messages from the } \\
\text { Dalai Lama and President } \\
\text { Clinton }\end{array}$ \\
\hline $\begin{array}{l}\text { Sinn Féin Head } \\
\text { Office }\end{array}$ & $\begin{array}{l}\text { Falls Road, } \\
\text { Belfast BT12 4PD }\end{array}$ & & $\begin{array}{l}\text { Side of the building showcases } \\
\text { Bobby Sands Mural } \\
\text { The front of the building } \\
\text { displays plagues dedicated to } \\
\text { party members killed during } \\
\text { the Troubles }\end{array}$ \\
\hline $\begin{array}{l}\text { Cultúrlann } \\
\text { McAdam Ó Fiach }\end{array}$ & $\begin{array}{l}216 \text { Falls Road, } \\
\text { Belfast BT12 6AH }\end{array}$ & $\begin{array}{l}1991 \text { - renovated } \\
\text { as culture centre }\end{array}$ & $\begin{array}{l}\text { Irish language and arts centre } \\
\text { Formally a Presbysterian } \\
\text { Church }\end{array}$ \\
\hline $\begin{array}{l}\text { Carrickfergus } \\
\text { Museum and } \\
\text { Civic Centre }\end{array}$ & $\begin{array}{l}11 \text { Antrim St, } \\
\text { Carrickfergus } \\
\text { BT38 7DG }\end{array}$ & & $\begin{array}{l}\text { Historical museum focusing on } \\
\text { Carrickfergus and the } \\
\text { surrounding area } \\
\text { Houses a community archive }\end{array}$ \\
\hline $\begin{array}{l}\text { Carrickfergus } \\
\text { Castle }\end{array}$ & $\begin{array}{l}\text { Marine Highway, } \\
\text { Carrickfergus } \\
\text { BT38 7BG }\end{array}$ & $12^{\text {th }}$ century & $\begin{array}{l}\text { Norman castle } \\
\text { Historical reenactments and } \\
\text { castle tour }\end{array}$ \\
\hline $\begin{array}{l}\text { Andrew Jackson } \\
\text { Cottage \& US } \\
\text { Rangers Centre }\end{array}$ & $\begin{array}{l}2 \text { Boneybefore, } \\
\text { Carrickfergus, } \\
\text { Antrim BT38 7EQ }\end{array}$ & & $\begin{array}{l}\text { The cottage was a single storey } \\
\text { restoration of a cottage that } \\
\text { Jackson's parents would have } \\
\text { lived in prior to their } \\
\text { immigration to the US in } 1765 \text {. } \\
\text { US Ranger Centre, next door is } \\
\text { an exhibition to the Rangers' } \\
\text { stationing at Carrickfergus } \\
\text { during WWII. }\end{array}$ \\
\hline $\begin{array}{l}\text { Flame! Gasworks } \\
\text { Museum of } \\
\text { Ireland }\end{array}$ & $\begin{array}{l}\text { 44 Irish Quarter } \\
\text { West, } \\
\text { Carrickfergus, } \\
\text { Antrim BT38 8AT }\end{array}$ & 1855 & $\begin{array}{l}\text { Restored coal gasworks, only } \\
\text { surviving one in Britain. }\end{array}$ \\
\hline $\begin{array}{l}\text { St Nicholas } \\
\text { Church of Ireland }\end{array}$ & $\begin{array}{l}3 \text { Market Place, } \\
\text { Carrickfergus, } \\
\text { Antrim BT38 } \\
\text { 7AW }\end{array}$ & 1182 & Christian Heritage Site \\
\hline
\end{tabular}




\begin{tabular}{|c|c|c|c|}
\hline Giant's Causeway & $\begin{array}{l}\text { 44 Causeway Rd, } \\
\text { Bushmills BT57 } \\
\text { 8SU }\end{array}$ & & $\begin{array}{l}\text { Basalt formation from ancient } \\
\text { volcanic eruption } \\
\text { Named UNESCO World } \\
\text { Heritage Site in } 1986 \\
\text { Visitor's Centre was part of the } \\
\text { NITB's Signature Projects and } \\
\text { reopened in } 2012\end{array}$ \\
\hline $\begin{array}{l}\text { Old Bushmill's } \\
\text { Distillery }\end{array}$ & $\begin{array}{l}2 \text { Distillery Rd, } \\
\text { Bushmills BT57 } \\
\text { 8XH }\end{array}$ & 1608 & $\begin{array}{l}\text { Claims to be the oldest } \\
\text { licensed distillery in the world } \\
\text { Distillery tours and museum }\end{array}$ \\
\hline $\begin{array}{l}\text { Mount Stewart } \\
\text { Estate }\end{array}$ & $\begin{array}{l}\text { Portaferry Rd, } \\
\text { Newtownards } \\
\text { BT22 2AD }\end{array}$ & 1839 & $\begin{array}{l}\text { Includes Mount Stewart house, } \\
\text { gardens, The Temple of the } \\
\text { Winds and Tír na nÓg burial } \\
\text { grounds }\end{array}$ \\
\hline $\begin{array}{l}\text { Ulster American } \\
\text { Folk Park }\end{array}$ & $\begin{array}{l}2 \text { Mellon Rd, } \\
\text { Omagh BT78 } \\
\text { 5QU }\end{array}$ & 1976 & $\begin{array}{l}\text { Listed in the National } \\
\text { Museums Northern Ireland } \\
\text { Explores historical link } \\
\text { between Ulster and America } \\
\text { Mellon House on grounds } \\
\text { Museum tour and historical } \\
\text { reeanctments }\end{array}$ \\
\hline $\begin{array}{l}\text { Diamond War } \\
\text { Memorial }\end{array}$ & $\begin{array}{l}\text { The Diamond, } \\
\text { Londonderry } \\
\text { BT48 6HP }\end{array}$ & 1927 & $\begin{array}{l}\text { Dedicated to residents who } \\
\text { fought and died in WWI }\end{array}$ \\
\hline $\begin{array}{l}\text { St Columb's } \\
\text { Cathedral }\end{array}$ & $\begin{array}{l}17 \text { London St, } \\
\text { Londonderry } \\
\text { BT48 6RQ }\end{array}$ & 1633 & $\begin{array}{l}\text { Church of Ireland (Protestant) } \\
\text { Original church was damaged } \\
\text { in an arms stockpile explosion } \\
\text { - the stones were used to build } \\
\text { the Walls of Derry }\end{array}$ \\
\hline $\begin{array}{l}\text { Blue Coat School } \\
\text { at First Derry } \\
\text { Presbyterian } \\
\text { Church }\end{array}$ & $\begin{array}{l}\text { Upper Magazine } \\
\text { Street, } \\
\text { Londonderry } \\
\text { BT48 6HY }\end{array}$ & $\begin{array}{l}1690 \text { s - first } \\
\text { church } \\
1780-\text { current } \\
\text { church and school }\end{array}$ & $\begin{array}{l}\text { The Blue Coat School Visitor } \\
\text { Centre has exhibits of the } \\
\text { Ulster Plantation, } \\
\text { Presbyterianism in } \\
\text { Derry/Londonderry. Other } \\
\text { exhibits are framed through } \\
\text { Presbyterianism and include } \\
\text { Industrialisation, WWI and } \\
\text { WWII, and the Irish Diaspora. }\end{array}$ \\
\hline $\begin{array}{l}\text { O’Doherty } \\
\text { Tower/ Derry } \\
\text { Tower Museum }\end{array}$ & $\begin{array}{l}\text { Union Hall Place, } \\
\text { Londonderry } \\
\text { BT48 6LU }\end{array}$ & $\begin{array}{l}1615 \\
1992-\text { museum } \\
\text { opened }\end{array}$ & $\begin{array}{l}\text { Museum presents history of } \\
\text { Derry/L'derry } \\
\text { Includes the Troubles in part of } \\
\text { its history exhibition }\end{array}$ \\
\hline Heritage Library & $\begin{array}{l}\text { 14 Bishop St, } \\
\text { Londonderry } \\
\text { BT48 6UW }\end{array}$ & & $\begin{array}{l}\text { Genealogy and Family History } \\
\text { collections of Derry/L'derry }\end{array}$ \\
\hline
\end{tabular}




\begin{tabular}{|c|c|c|c|}
\hline $\begin{array}{l}\text { Foyle Valley } \\
\text { Railway }\end{array}$ & $\begin{array}{l}30 \text { Foyle Rd, } \\
\text { Londonderry, } \\
\text { BT48 6SQ }\end{array}$ & 1989 & Railway museum \\
\hline $\begin{array}{l}\text { Derry Visitor and } \\
\text { Convention } \\
\text { Bureau }\end{array}$ & $\begin{array}{l}\text { 44 Foyle St, } \\
\text { Londonderry } \\
\text { BT48 6AT }\end{array}$ & & Derry/L'derry visitors centre \\
\hline $\begin{array}{l}\text { Bloody Sunday } \\
\text { Memorial }\end{array}$ & $\begin{array}{l}\text { Rossville St, } \\
\text { Derry }\end{array}$ & & $\begin{array}{l}\text { Memorial to victims of Bloody } \\
\text { Sunday } 1972 \\
\text { Located near Museum of Free } \\
\text { Derry }\end{array}$ \\
\hline $\begin{array}{l}\text { Museum of Free } \\
\text { Derry }\end{array}$ & $\begin{array}{l}55 \text { Glenfada Park, } \\
\text { Derry BT48 9DR }\end{array}$ & 2005 & $\begin{array}{l}\text { Examines the history of the } \\
\text { civil rights movement and the } \\
\text { Troubles in Derry/L'derry with } \\
\text { an emphasis on the Bogside } \\
\text { area }\end{array}$ \\
\hline $\begin{array}{l}\text { Free Derry } \\
\text { Corner, Murals \& } \\
\text { Monument }\end{array}$ & $\begin{array}{l}\text { Rossville St, } \\
\text { Derry }\end{array}$ & & $\begin{array}{l}\text { House gable with Free Derry } \\
\text { mural } \\
\text { Murals dedicated to events of } \\
\text { the Battle of the Bogside and } \\
\text { Bloody Sunday } \\
\text { Monument to the H-block } \\
\text { prisoners }\end{array}$ \\
\hline The Guildhall & $\begin{array}{l}\text { Guildhall St, } \\
\text { Londonderry } \\
\text { BT48 6DQ }\end{array}$ & 1890 & $\begin{array}{l}\text { Houses Derry City Council } \\
\text { Target of several attacks } \\
\text { during the Troubles }\end{array}$ \\
\hline $\begin{array}{l}\text { St Augustine's } \\
\text { Church }\end{array}$ & $\begin{array}{l}\text { Palace St, } \\
\text { Londonderry } \\
\text { BT48 6PP }\end{array}$ & 1872 & $\begin{array}{l}\text { Church sites on the site of St } \\
\text { Columba's/Colmcille } \\
\text { monastery founded } \\
546 \mathrm{CE} \\
\text { Original St Augustine's dates } \\
\text { to } 1164 \text { and was named the } \\
\text { Black Church }\end{array}$ \\
\hline $\begin{array}{l}\text { Apprentice Boys } \\
\text { Memorial Hall }\end{array}$ & $\begin{array}{l}13 \text { Society St, } \\
\text { Londonderry } \\
\text { BT48 6PJ }\end{array}$ & 1877 & $\begin{array}{l}\text { Headquarters of Apprentice } \\
\text { Boys of Derry Association } \\
\text { Houses a Museum dedicated to } \\
\text { the history of the Siege of } \\
\text { Londonderry } 1688-1689\end{array}$ \\
\hline $\begin{array}{l}\text { St Eugene's } \\
\text { Cathedral }\end{array}$ & $\begin{array}{l}\text { Francis St, Derry } \\
\text { BT48 9AP }\end{array}$ & 1873 & $\begin{array}{l}\text { Roman Catholic } \\
\text { Seat of the Bishop of Derry }\end{array}$ \\
\hline Magee College & & 1865 & $\begin{array}{l}\text { Began as a Presbyterian } \\
\text { theological college } \\
\text { Used as a base of operations by } \\
\text { Royal Navy during WWII } \\
\text { Absorbed by Ulster University } \\
\text { (then New University of } \\
\text { Ulster) in } 1969\end{array}$ \\
\hline
\end{tabular}




\begin{tabular}{|c|c|c|c|}
\hline Fountain Estate & $\begin{array}{l}\text { The Fountain, } \\
\text { Londonderry } \\
\text { BT48 }\end{array}$ & & $\begin{array}{l}\text { The last Protestant working } \\
\text { class neighborhood on the city } \\
\text { side of the River Foyle } \\
\text { Murals and large displays } \\
\text { declare the neighborhood as } \\
\text { "Londonderry West Bank } \\
\text { Loyalists Still Under Siege No } \\
\text { Surrender" }\end{array}$ \\
\hline $\begin{array}{l}\text { Workhouse } \\
\text { Museum }\end{array}$ & $\begin{array}{l}23 \text { Glendermott } \\
\text { Rd, Waterside } \\
\text { BT48 6BG }\end{array}$ & $\begin{array}{l}1840 \\
1998-\text { as museum }\end{array}$ & $\begin{array}{l}\text { Workhouse exhibition } \\
\text { detailing lives of workers } \\
\text { Possibly closed permanently } 5 \\
\text { April } 2014\end{array}$ \\
\hline $\begin{array}{l}\text { Walled City of } \\
\text { Derry }\end{array}$ & & & $\begin{array}{l}\text { Stone walls surrounding } \\
\text { original city of Derry/L'derry }\end{array}$ \\
\hline Ebrington Square & $\begin{array}{l}\text { Londonderry } \\
\text { BT47 6JU }\end{array}$ & 2012 & $\begin{array}{l}\text { Began as parade space for the } \\
\text { Army } \\
\text { Connected to the Peace Bridge } \\
\text { Music venue } \\
\text { Includes interactive art } \\
\text { installation Mute Meadow }\end{array}$ \\
\hline $\begin{array}{l}\text { Sperrin Park } \\
\text { Murals }\end{array}$ & $\begin{array}{l}\text { Sperrin Park, } \\
\text { Londonderry } \\
\text { BT47 6NG }\end{array}$ & & Loyalist murals \\
\hline Peace Bridge & Derry BT48 7NN & 2011 & $\begin{array}{l}\text { Bicycle and Foot Bridge } \\
\text { Metaphor for bridging the gap } \\
\text { between Catholic "Cityside" } \\
\text { and Protestant "Waterside" of } \\
\text { Derry/L'derry }\end{array}$ \\
\hline $\begin{array}{l}\text { Tullylagan } \\
\text { Country House } \\
\text { Hotel }\end{array}$ & $\begin{array}{l}\text { 40B Tullylagan } \\
\text { Rd, Cookstown } \\
\text { BT80 8UP }\end{array}$ & & $\begin{array}{l}\text { Home of Harry Ferguson - } \\
\text { inventor of the modern tractor } \\
\text { Houses tractor museum } \\
\text { Stop on Harry Ferguson Trail }\end{array}$ \\
\hline $\begin{array}{l}\text { Downshire Arms } \\
\text { Hotel }\end{array}$ & $\begin{array}{l}95 \text { Newry St, } \\
\text { Banbridge BT32 } \\
\text { 3EF }\end{array}$ & 1816 & $\begin{array}{l}\text { Originally the second stop on } \\
\text { the coach line between Belfast } \\
\text { and Dublin }\end{array}$ \\
\hline Balloo House & $\begin{array}{l}1 \text { Comber Rd, } \\
\text { Killinchy BT23 } \\
\text { 6PA }\end{array}$ & Late $17^{\text {th }}$ century & $\begin{array}{l}\text { Building began as a coaching } \\
\text { stop } \\
\text { Restaurant }\end{array}$ \\
\hline $\begin{array}{l}\text { Groucho's on the } \\
\text { Square }\end{array}$ & $\begin{array}{l}1 \text { The Square, } \\
\text { Richill, Armagh } \\
\text { BT61 9PP }\end{array}$ & Mid $17^{\text {th }}$ century & $\begin{array}{l}\text { Original site was a tavern with } \\
\text { a tunnel linking it to Richill } \\
\text { Castle }\end{array}$ \\
\hline Denvir's Hotel & $\begin{array}{l}14 \text { English St, } \\
\text { Downpatrick } \\
\text { BT30 6AB }\end{array}$ & $\begin{array}{l}1642-\text { coach } \\
\text { house built } \\
1809- \\
\text { Downpatrick to }\end{array}$ & $\begin{array}{l}\text { Starting point of the first } \\
\text { passenger coach service } \\
\text { between Downpatrick and } \\
\text { Belfast } \\
\text { Oldest surviving coach house }\end{array}$ \\
\hline
\end{tabular}




\begin{tabular}{|c|c|c|c|}
\hline & & $\begin{array}{l}\text { Belfast service } \\
\text { begins }\end{array}$ & \\
\hline Dark Hedges & $\begin{array}{l}\text { Bregagh Rd, } \\
\text { Ballymoney BT53 } \\
\text { 8TP }\end{array}$ & 1700s - planted & $\begin{array}{l}\text { Drive of Gracehill Estate } \\
\text { Stop on Game of Throne tours }\end{array}$ \\
\hline $\begin{array}{l}\text { Ballymoney } \\
\text { Museum and } \\
\text { Visitors Centre }\end{array}$ & $\begin{array}{l}1 \text { Townhead St, } \\
\text { Ballymoney BT53 } \\
6 \mathrm{BE}\end{array}$ & 2009 & $\begin{array}{l}\text { Bronze Age and Medieval } \\
\text { exhibits } \\
\text { Exhibits on political upheaval } \\
\text { in the area including } 1641 \\
\text { Rebellion and } 1798 \text { United } \\
\text { Irish Rebellion } \\
\text { Exibit of Irish Motorcycle } \\
\text { Road Racing }\end{array}$ \\
\hline $\begin{array}{l}\text { Lagan Valley } \\
\text { Island }\end{array}$ & $\begin{array}{l}\text { Lisburn, BT27 } \\
\text { 4RL }\end{array}$ & $\begin{array}{l}2001 \text { - conference } \\
\text { and events centre }\end{array}$ & $\begin{array}{l}\text { Once the site for Island Mill } \\
\text { Spinning Company } \\
\text { Stop on Harry Ferguson Trail }\end{array}$ \\
\hline $\begin{array}{l}\text { Hillsborough } \\
\text { Forest }\end{array}$ & $\begin{array}{l}\text { Hillsborough, } \\
\text { Down, BT26 6DP }\end{array}$ & $\begin{array}{l}2009-\text { bronze } \\
\text { memorial }\end{array}$ & $\begin{array}{l}\text { Site of Harry Ferguson's first } \\
\text { successful flight } \\
\text { Stop on Harry Ferguson Trail }\end{array}$ \\
\hline $\begin{array}{l}\text { Hillsborough } \\
\text { Castle }\end{array}$ & $\begin{array}{l}\text { Main Street, } \\
\text { Hillsborough, } \\
\text { Down BT26 6AG }\end{array}$ & $\begin{array}{l}1760 \text { - earlier } \\
\text { house } \\
1797 \text { - current }\end{array}$ & $\begin{array}{l}\text { Originally the home of the } \\
\text { Marguises of Downshire, now } \\
\text { the official residence of the } \\
\text { Secretary of State for Northern } \\
\text { Ireland }\end{array}$ \\
\hline Hillsborough Fort & $\begin{array}{l}32 \text { Main Street, } \\
\text { Hillsborough, } \\
\text { Down BT26, 6AE }\end{array}$ & 1650 & $\begin{array}{l}\text { Royal fortress during reign of } \\
\text { Charles II }\end{array}$ \\
\hline $\begin{array}{l}\text { Downshire } \\
\text { Monument }\end{array}$ & $\begin{array}{l}\text { Hillsborough, } \\
\text { Down BT26 6EX }\end{array}$ & & $\begin{array}{l}\text { Doric column dedicated to } \\
\text { third Marquis of Downshire, }\end{array}$ \\
\hline $\begin{array}{l}\text { Drumlough } \\
\text { Presbyterian } \\
\text { Church }\end{array}$ & $\begin{array}{l}1 \text { Raffertys Hill, } \\
\text { Drumlough, } \\
\text { Hillsborough, } \\
\text { Down BT26 6QB } \\
\end{array}$ & 1818 & $\begin{array}{l}\text { Stop on Harry Ferguson Trail } \\
\text { Ferguson family gravesites }\end{array}$ \\
\hline $\begin{array}{l}\text { Growell Gospel } \\
\text { Hall }\end{array}$ & $\begin{array}{l}\text { 61 Magherconluce } \\
\text { Rd, Hillsborough, } \\
\text { Down BT26 6QH }\end{array}$ & 1933 & Stop on Harry Ferguson Trail \\
\hline $\begin{array}{l}\text { Ferguson } \\
\text { Homestead \& } \\
\text { Memorial } \\
\text { Gardens }\end{array}$ & $\begin{array}{l}\text { 41 Magherconluce } \\
\text { Rd, Hillsborough, } \\
\text { Down BT26 6QH }\end{array}$ & $\begin{array}{l}2009-\text { as a tourist } \\
\text { site }\end{array}$ & $\begin{array}{l}\text { Childhood home of Harry } \\
\text { Ferguson } \\
\text { Memorial is located across the } \\
\text { street from the House } \\
\text { Stop on Harry Ferguson Trail }\end{array}$ \\
\hline Dromore Village & $\begin{array}{l}\text { Dromore, Down } \\
\text { BT25 }\end{array}$ & & $\begin{array}{l}\text { Stop on Harry Ferguson Trail } \\
\text { A PIRA bomb attack on a } \\
\text { drapery shop in April } 1976 \\
\text { killed } 3 \text { Protestant civilians }\end{array}$ \\
\hline
\end{tabular}




\begin{tabular}{|c|c|c|c|}
\hline & & & $\begin{array}{l}\text { 1 Catholic civilian was killed } \\
\text { in July } 1988 \text { by UFF. }\end{array}$ \\
\hline $\begin{array}{l}\text { Ulster Aviation } \\
\text { Collection } \\
\text { Maze/Long Kesh }\end{array}$ & $\begin{array}{l}\text { Halftown Rd, } \\
\text { Lisburn BT27 } \\
\text { 5RF }\end{array}$ & $\begin{array}{l}1941 \text { - hangers } \\
\text { erected } \\
1971 \text { - Maze } \\
\text { prison complex } \\
\text { opened } \\
2006 \text { - Prison } \\
\text { demolished } \\
2013 \text { - in talks to } \\
\text { refurbish } \\
\text { remaining prison } \\
\text { buildings into } \\
\text { conflict } \\
\text { transformation } \\
\text { centre }\end{array}$ & $\begin{array}{l}\text { Collection of historic aircraft } \\
\text { housed in two hangers dating } \\
\text { to WWII } \\
\text { Hangers are a stop on Harry } \\
\text { Ferguson Trail - however it is } \\
\text { not currently open to the public } \\
\text { outside of group tours } \\
\text { Maze Prison also known as } \\
\text { Long Kesh or The H Blocks - } \\
\text { house paramilitary prisoners } \\
\text { during the Troubles } \\
\text { Site of } 1981 \text { Hunger Strike }\end{array}$ \\
\hline $\begin{array}{l}\text { Brookhall } \\
\text { Historical Farm }\end{array}$ & $\begin{array}{l}2 \text { Horse Park, } \\
\text { Magheragall, } \\
\text { Lisburn, Antrim } \\
\text { BT28 2QU }\end{array}$ & Mid $17^{\text {th }}$ century & $\begin{array}{l}\text { Farm museum } \\
\text { Stop on Harry Ferguson Trail }\end{array}$ \\
\hline $\begin{array}{l}\text { Central } \\
\text { Promenade }\end{array}$ & $\begin{array}{l}\text { Newcastle, Down } \\
\text { BT33 OAA }\end{array}$ & & $\begin{array}{l}\text { Stop on Harry Ferguson Trail } \\
\text { Stone memorial marks } \\
\text { Ferguson's } 1910 \text { flight }\end{array}$ \\
\hline $\begin{array}{l}\text { Headhunters } \\
\text { Barber Shop \& } \\
\text { Railway Museum }\end{array}$ & $\begin{array}{l}5 \text { Darling St, } \\
\text { Enniskillen, } \\
\text { Fermanagh BT74 } \\
\text { 7DP }\end{array}$ & 2002 & $\begin{array}{l}\text { Old style barber shop } \\
\text { Railway museum featuring } \\
\text { Great Northern Railway }\end{array}$ \\
\hline $\begin{array}{l}\text { Forthill Park and } \\
\text { Cole's Monument }\end{array}$ & $\begin{array}{l}\text { Enniskillen, BT74 } \\
\text { 7BA }\end{array}$ & 1857 & $\begin{array}{l}\text { Town park with monument } \\
\text { dedicated to Sir Galbraith } \\
\text { Lowry Cole. }\end{array}$ \\
\hline Castle Coole & $\begin{array}{l}\text { Enniskillen, } \\
\text { Fermanagh BT74 } \\
\text { 6JY }\end{array}$ & 1798 & $\begin{array}{l}\text { Neo-Classical mansion. } \\
\text { National Trust owned. }\end{array}$ \\
\hline Enniskillen Castle & $\begin{array}{l}\text { Enniskillen, } \\
\text { Fermanagh, BT74 } \\
\text { 7HL }\end{array}$ & $1420 \mathrm{~s}$ & $\begin{array}{l}\text { Built as a castle for the } \\
\text { Maguire clan. In } 17^{\text {th }} \text { century } \\
\text { became an English garrison } \\
\text { fort and military barracks. } \\
\text { Houses Enniskillen Castle } \\
\text { museums that include } \\
\text { Fermanagh county history. }\end{array}$ \\
\hline $\begin{array}{l}\text { The Inniskillings } \\
\text { Museum }\end{array}$ & $\begin{array}{l}\text { Enniskillen Castle } \\
\text { Museums, } \\
\text { Enniskillen, } \\
\text { Fermanagh BT74 } \\
\text { 7HL }\end{array}$ & & $\begin{array}{l}\text { Museum dedicated to the } \\
\text { Royal Inniskilling Fusiliers and } \\
\text { the } 5^{\text {th }} \text { Royal Inniskilling } \\
\text { Dragoon Guards. }\end{array}$ \\
\hline
\end{tabular}




\begin{tabular}{|c|c|c|c|}
\hline $\begin{array}{l}\text { Fermanagh } \\
\text { County Museum }\end{array}$ & $\begin{array}{l}\text { Enniskillen Castle } \\
\text { Museums, } \\
\text { Enniskillen, } \\
\text { Fermanagh BT74 } \\
\text { 7HL }\end{array}$ & & $\begin{array}{l}\text { Prehistory and natural history } \\
\text { of Fermanagh }\end{array}$ \\
\hline $\begin{array}{l}\text { Enniskillen } \\
\text { Library }\end{array}$ & $\begin{array}{l}\text { Halls Lane, } \\
\text { Enniskillen, } \\
\text { Fermanagh BT74 } \\
\text { 7DR }\end{array}$ & & $\begin{array}{l}\text { Houses the Fermanagh County } \\
\text { Irish \& Local Studies } \\
\text { Department. }\end{array}$ \\
\hline $\begin{array}{l}\text { Enniskillen Town } \\
\text { Hall }\end{array}$ & $\begin{array}{l}2 \text { Townhall Street, } \\
\text { Enniskillen, } \\
\text { Fermanagh BT74 }\end{array}$ & & $\begin{array}{l}\text { Houses District Registrar's } \\
\text { office. Information on the } \\
\text { county's births, deaths and } \\
\text { marraiges can be searched } \\
\text { back to the mid-1800s }\end{array}$ \\
\hline $\begin{array}{l}\text { Sheelin Irish Lace } \\
\text { Shop and } \\
\text { Museum }\end{array}$ & $\begin{array}{l}\text { Bellanaleck, } \\
\text { Enniskillen, } \\
\text { Fermanagh BT92 } \\
\text { 2BA }\end{array}$ & & \\
\hline $\begin{array}{l}\text { Aughakillymaude } \\
\text { Mummers Centre }\end{array}$ & $\begin{array}{l}\text { Knockninny Road, } \\
\text { Derrylin, } \\
\text { Fermanagh BT92 } \\
\text { 9JT }\end{array}$ & & $\begin{array}{l}\text { Mummers Exhibit including } \\
\text { sculptures and photo galleries. }\end{array}$ \\
\hline Crom Estate & $\begin{array}{l}\text { Newtownbutler, } \\
\text { Enniskillen, } \\
\text { Fermanagh BT92 } \\
\text { 8AP }\end{array}$ & $\begin{array}{l}1611-1^{\text {st }} \text { mansion } \\
\text { constructed } \\
1840-\text { neo-Tudor } \\
\text { castle built }\end{array}$ & $\begin{array}{l}\text { Plantation era mansion on } \\
\text { Upper Lough Erne. National } \\
\text { Trust property The new castle } \\
\text { is still the property of the Earl } \\
\text { of Erne and is not open to the } \\
\text { public. }\end{array}$ \\
\hline Florence Court & $\begin{array}{l}\text { Enniskillen, } \\
\text { Fermanagh BT92 } \\
\text { 1DB }\end{array}$ & Early $18^{\text {th }}$ century & $\begin{array}{l}\text { Cole family house and estate. } \\
\text { National Trust owned. }\end{array}$ \\
\hline $\begin{array}{l}\text { Belleek Pottery } \\
\text { Visitors Centre }\end{array}$ & $\begin{array}{l}3 \text { Main St Belleek, } \\
\text { Fermanagh BT93 } \\
\text { 3FY }\end{array}$ & 1989 & $\begin{array}{l}\text { Houses Belleek history } \\
\text { museum } \\
\text { Offers tours of Belleek Pottery } \\
\text { building }\end{array}$ \\
\hline The Barracks & $\begin{array}{l}\text { Belleek, } \\
\text { Fermanagh BT93 }\end{array}$ & $\begin{array}{l}\text { Housed Royal } \\
\text { Irish Constabulary } \\
\text { (RIC) until } 1922 \\
\text { Housed Royal } \\
\text { Ulster } \\
\text { Constabulary } \\
\text { (RUC) until } 2001 \\
\text { Currently Police } \\
\text { Service of } \\
\text { Northern Ireland } \\
\text { station }\end{array}$ & $\begin{array}{l}\text { Multiple bombings were } \\
\text { attempted on The Barracks } \\
\text { throughout the Troubles }\end{array}$ \\
\hline
\end{tabular}




\begin{tabular}{|c|c|c|c|}
\hline The Thatch & $\begin{array}{l}\text { Main St, Belleek, } \\
\text { Fermanagh BT93 } \\
\text { 3FX }\end{array}$ & & $\begin{array}{l}\text { Oldest original thatch roofed } \\
\text { building in Fermanagh } \\
\text { Today it is a coffee shop }\end{array}$ \\
\hline $\begin{array}{l}\text { The Black Cat } \\
\text { Cove }\end{array}$ & $\begin{array}{l}\text { Main St, Belleek, } \\
\text { Fermanagh BT93 } \\
\text { 3FX }\end{array}$ & & $\begin{array}{l}\text { Originally the Bloomfield } \\
\text { Hotel then Commercial Hotel } \\
\text { Daly family owned the } \\
\text { building as a pub/grocery - Fr } \\
\text { Edward Daly, elected Bishop } \\
\text { of Derry in 1974, rose to } \\
\text { prominence during the events } \\
\text { of Bloody Sunday two years } \\
\text { earlier }\end{array}$ \\
\hline $\begin{array}{l}\text { St Patrick's } \\
\text { Terrace }\end{array}$ & $\begin{array}{l}\text { Belleek, } \\
\text { Fermanagh BT93 } \\
\text { (near st davog's } \\
\text { primary school on } \\
\text { A47) }\end{array}$ & & $\begin{array}{l}\text { Houses built for Irish pottery } \\
\text { workers } \\
\text { Not as elaborate as nearby } \\
\text { housing for English pottery } \\
\text { workers }\end{array}$ \\
\hline Rathmore Terrace & $\begin{array}{l}\text { Belleek, } \\
\text { Fermanagh, BT93 } \\
\text { (backside can be } \\
\text { viewed on google } \\
\text { streets just right of } \\
\text { Church of Ireland) }\end{array}$ & & $\begin{array}{l}\text { Houses built for English } \\
\text { pottery workers }\end{array}$ \\
\hline Belleek Chapel & $\begin{array}{l}\text { Belleek, } \\
\text { Fermanagh, BT93 } \\
\text { (across the street } \\
\text { from St davog's } \\
\text { primary school } \\
\text { and the St } \\
\text { Patrick's terrace) }\end{array}$ & $\begin{array}{l}1892-\text { St Patrick's } \\
\text { Roman Catholic } \\
\text { Church built on } \\
\text { site }\end{array}$ & $\begin{array}{l}\text { The original church was a } \\
\text { wooden Mass house } \\
\text { Fr Edward Daly was ordained } \\
\text { here in } 1957\end{array}$ \\
\hline $\begin{array}{l}\text { Belleek Church of } \\
\text { Ireland }\end{array}$ & $\begin{array}{l}\text { Belleek, } \\
\text { Fermanagh BT93 } \\
\text { (to the right of St } \\
\text { Patrick's Roman } \\
\text { Catholic Church }\end{array}$ & $\begin{array}{l}1909- \\
\text { consecration as } \\
\text { Church of Ireland }\end{array}$ & $\begin{array}{l}\text { Was previously a school } \\
\text { Home to three stained glass } \\
\text { potters' windows }\end{array}$ \\
\hline $\begin{array}{l}\text { Belleek Railway } \\
\text { Station }\end{array}$ & $\begin{array}{l}\text { Belleek, } \\
\text { Fermanagh BT93 } \\
\text { (in front of } \\
\text { Rathmore terrace) }\end{array}$ & 1866 & $\begin{array}{l}\text { A stop on the Great Northern } \\
\text { Railway (GNR) to Bundoran } \\
\text { GNR closed in } 1957 \\
\text { Now a daycare centre }\end{array}$ \\
\hline Black Biddy's & $\begin{array}{l}\text { Main St, Belleek, } \\
\text { Fermanagh BT93 } \\
\text { (robin's egg blue } \\
\text { building) }\end{array}$ & & $\begin{array}{l}\text { A pub whose clientele were the } \\
\text { pottery workers from Belleek } \\
\text { Pottery } \\
\text { Now The Dresser }\end{array}$ \\
\hline $\begin{array}{l}\text { The Fiddlestone } \\
\text { Pub }\end{array}$ & $\begin{array}{l}\text { Main St, Belleek, } \\
\text { Fermanagh BT93 }\end{array}$ & & $\begin{array}{l}\text { Formally owned by the } \\
\text { Moohan family }\end{array}$ \\
\hline
\end{tabular}




\begin{tabular}{|c|c|c|c|}
\hline $\begin{array}{l}\text { Cleary's Public } \\
\text { House }\end{array}$ & $\begin{array}{l}\text { Main St, Belleek, } \\
\text { Fermanagh BT93 }\end{array}$ & & $\begin{array}{l}\text { Formally a hotel } \\
\text { Known locally as The Corner } \\
\text { House }\end{array}$ \\
\hline The Carlton Hotel & $\begin{array}{l}\text { Main St, Belleek, } \\
\text { Fermanagh BT93 }\end{array}$ & & $\begin{array}{l}\text { Damaged by explosions in } \\
1971 \text { and } 1973\end{array}$ \\
\hline $\begin{array}{l}\text { Irvinestown } \\
\text { Centenary } \\
\text { Sculpture Garden }\end{array}$ & $\begin{array}{l}\text { Lisnarick Road, } \\
\text { Irvinestown, } \\
\text { Fermanagh BT94 } \\
\text { 1EY }\end{array}$ & & $\begin{array}{l}\text { Devenish figures of saints } \\
\text { carved out of oak wood. }\end{array}$ \\
\hline $\begin{array}{l}\text { Caldragh } \\
\text { Cemetery }\end{array}$ & $\begin{array}{l}\text { Boa Island, } \\
\text { Fermanagh }\end{array}$ & $\begin{array}{l}\text { Estimated to no } \\
\text { earlier than } 8^{\text {th }} \\
\text { century }\end{array}$ & $\begin{array}{l}\text { Two Janus faced stone } \\
\text { carvings stand in the }\end{array}$ \\
\hline $\begin{array}{l}\text { Ross Lough } \\
\text { Crannog }\end{array}$ & $\begin{array}{l}\text { Ross Lough, } \\
\text { Boho, Enniskillen, } \\
\text { Fermanagh }\end{array}$ & & $\begin{array}{l}\text { 1641 Rebellion was planned by } \\
\text { Phelim O'Neill here. }\end{array}$ \\
\hline $\begin{array}{l}\text { Toneel North } \\
\text { High Cross }\end{array}$ & $\begin{array}{l}\text { Boho, Enniskillen, } \\
\text { Fermanagh BT74 } \\
\text { 8BF }\end{array}$ & $10^{\text {th }}$ century & $\begin{array}{l}\text { Located in Sacred Heart } \\
\text { Catholic Church }\end{array}$ \\
\hline Reyfad Stones & $\begin{array}{l}\text { Boho, Enniskillen, } \\
\text { Fermanagh BT74 }\end{array}$ & $\begin{array}{l}\text { 2000BCE to } \\
600 \mathrm{CE}\end{array}$ & $\begin{array}{l}\text { Six limestone boulders } \\
\text { decorated with cup and ring } \\
\text { motifs. }\end{array}$ \\
\hline Noon's Hole & $\begin{array}{l}\text { Boho, Enniskillen, } \\
\text { Fermanagh BT74 }\end{array}$ & & $\begin{array}{l}266 \mathrm{ft} \text { shaft that leads to the } \\
\text { Arch Cave }\end{array}$ \\
\hline Linnet Inn & $\begin{array}{l}174 \text { Boho Road, } \\
\text { Tullyholvin } \\
\text { Lower, } \\
\text { Enniskillen, } \\
\text { Fermanagh BT74 } \\
\text { 5BB }\end{array}$ & $19^{\text {th }}$ century & $\begin{array}{l}\text { The inn was established on a } \\
\text { coach road. }\end{array}$ \\
\hline Boho Waterfall & $\begin{array}{l}\text { Boho, Enniskillen, } \\
\text { Fermanagh BT74 }\end{array}$ & & \\
\hline $\begin{array}{l}\text { Boho Church of } \\
\text { Ireland }\end{array}$ & $\begin{array}{l}\text { Boho, Enniskillen, } \\
\text { Fermanagh BT74 }\end{array}$ & 1777 & $\begin{array}{l}\text { The medieval doorway is a } \\
\text { tourist attraction }\end{array}$ \\
\hline Pollagallum & $\begin{array}{l}\text { Boho, Enniskillen, } \\
\text { Fermanagh BT74 }\end{array}$ & & \\
\hline Eisenhower Pier & $\begin{array}{l}\text { The Seafront, } \\
\text { Bangor, Down } \\
\text { BT20 5ED }\end{array}$ & 2005 - renamed & $\begin{array}{l}\text { Mosaics of Bangor's role in } \\
\text { WWII. The Bangor Penguins, } \\
\text { a colony of black guillemots } \\
\text { live beneath the pier. }\end{array}$ \\
\hline McKee Clock & $\begin{array}{l}\text { Bangor, Down, } \\
\text { BT20 5ED }\end{array}$ & 1915 & Bombed during WWII \\
\hline $\begin{array}{l}\text { HM Coastguard } \\
\text { Bangor }\end{array}$ & $\begin{array}{l}\text { Bregenz House, } 5 \\
\text { Quay Street, } \\
\text { Bangor, Down } \\
\text { BT20 5ED } \\
\end{array}$ & & \\
\hline
\end{tabular}




\begin{tabular}{|c|c|c|c|}
\hline Sunken Gardens & $\begin{array}{l}\text { Bangor Marina, } \\
\text { Bangor, BT20 } \\
\text { 5ED }\end{array}$ & & \\
\hline $\begin{array}{l}\text { North Down } \\
\text { Museum }\end{array}$ & $\begin{array}{l}\text { Town Hall, Castle } \\
\text { Park Avenue, } \\
\text { Bangor, Down } \\
\text { BT20 4BT }\end{array}$ & & $\begin{array}{l}\text { Exhibits on Bangor Abbey, } \\
\text { early Christianity in Europe } \\
\text { and the Viking conquest of the } \\
\text { coast of Ireland. } \\
\text { Has the only complete folio of } \\
\text { plantation era maps. }\end{array}$ \\
\hline Bangor Abbey & $\begin{array}{l}1 \text { St Malachy's } \\
\text { Way, Bangor, } \\
\text { Down BT20 4JF }\end{array}$ & 558 & $\begin{array}{l}\text { Established by St Comgall, } \\
\text { who tutored St Columbanus at } \\
\text { the school in the abbey. }\end{array}$ \\
\hline Bangor Castle & $\begin{array}{l}\text { Castle Park Road, } \\
\text { Bangor, Down, } \\
\text { BT20 4BN }\end{array}$ & $\begin{array}{l}1542-\text { abbey } \\
\text { building } \\
1852-\text { Estate } \\
\text { building }\end{array}$ & $\begin{array}{l}\text { Houses North Down Borough } \\
\text { Council. Originally the home } \\
\text { of Robert Edward Ward. }\end{array}$ \\
\hline Grey Point Fort & $\begin{array}{l}\text { The Fort, Bangor, } \\
\text { Down, BT19 1PU }\end{array}$ & & $\begin{array}{l}\text { WWII era fort. Includes } \\
\text { obelisk used by Harland \& } \\
\text { Wolff to monitor vessel } \\
\text { speeds. }\end{array}$ \\
\hline $\begin{array}{l}\text { Cockle Row } \\
\text { Cottages }\end{array}$ & $\begin{array}{l}\text { The Harbour, } \\
\text { Main Street, } \\
\text { Groomsport, } \\
\text { Down BT19 6JR }\end{array}$ & & $\begin{array}{l}\text { Interactive fishing village } \\
\text { recreation from the } 19^{\text {th }} \\
\text { century }\end{array}$ \\
\hline Holywood Priory & $\begin{array}{l}\text { High Street, } \\
\text { Holywood, Down } \\
\text { BT19 9AB }\end{array}$ & $13^{\text {th }}$ century & $\begin{array}{l}\text { Holywoods town parish church } \\
\text { from } 1615 \text { to } 1844 \text {. Burial } \\
\text { place of Robert Lloyd and } \\
\text { Rosamund Praeger. }\end{array}$ \\
\hline $\begin{array}{l}\text { Holywood } \\
\text { Maypole }\end{array}$ & $\begin{array}{l}\text { High Street/Shore } \\
\text { Street, Holywood, } \\
\text { Down BT18 9AB }\end{array}$ & $1620 \mathrm{~s}$ & $\begin{array}{l}\text { Only surviving Maypole in } \\
\text { Ireland. }\end{array}$ \\
\hline $\begin{array}{l}\text { Ulster Folk and } \\
\text { Transport } \\
\text { Museum }\end{array}$ & $\begin{array}{l}\text { 153 Bangor Road, } \\
\text { Holywood BT18 } \\
\text { OEU }\end{array}$ & 1967 & $\begin{array}{l}\text { Two separate museums Folk } \\
\text { museum -illustrates life and } \\
\text { traditions of people in } \\
\text { Northern Ireland Transport } \\
\text { museum - exhibits transport } \\
\text { methods by land, air and sea } \\
\text { throughout time } \\
\text { Stop on Harry Ferguson Trail }\end{array}$ \\
\hline Moira Rough Fort & $\begin{array}{l}\text { Old Kilmore Rd, } \\
\text { Moira, Craigavon, } \\
\text { Down BT67 }\end{array}$ & $\sim 1500$ years ago & \\
\hline $\begin{array}{l}\text { Pretty Mary's } \\
\text { Fort }\end{array}$ & $\begin{array}{l}\text { Glebe Gardens, } \\
\text { Moira, Craigavon, } \\
\text { Down BT67 0FE }\end{array}$ & $\sim 1500$ years ago & \\
\hline
\end{tabular}




\begin{tabular}{|c|c|c|c|}
\hline Claremont Rath & $\begin{array}{l}\text { Rawdon Place, } \\
\text { Moira, Craigavon, } \\
\text { Down BT67 0NX }\end{array}$ & $\sim 1500$ years ago & \\
\hline $\begin{array}{l}\text { St John's/Moira } \\
\text { Parish Church }\end{array}$ & $\begin{array}{l}\text { St John's Park, } \\
\text { Moira, Craigavon, } \\
\text { Down BT67 0NL }\end{array}$ & 1721 & $\begin{array}{l}\text { Church of Ireland. Christian } \\
\text { Heritage Site. }\end{array}$ \\
\hline $\begin{array}{l}\text { Legananny } \\
\text { Dolmen }\end{array}$ & $\begin{array}{l}\text { Dolmen Road, } \\
\text { Castlewellan, } \\
\text { Banbridge, Down } \\
\text { BT31 9TG } \\
\end{array}$ & Neolithic & Megalith dolmen \\
\hline Finnis Souterrain & $\begin{array}{l}\text { Carrigagh Road, } \\
\text { Dromore, } \\
\text { Banbridge, Down } \\
\text { BT25 2HS }\end{array}$ & $9^{\text {th }}$ century & $\begin{array}{l}\text { Also called Binders Cove. } \\
\text { Hiding and storage place } \\
\text { dating to the Viking invasion. }\end{array}$ \\
\hline Giant's Ring & $\begin{array}{l}\text { Lisburn, Down } \\
\text { BT28 8LE }\end{array}$ & $\sim 3000-2700 \mathrm{BCE}$ & $\begin{array}{l}\text { 200m earthwork with a } \\
\text { megalithic chamber inside. }\end{array}$ \\
\hline Crewe Hill & $\begin{array}{l}\text { Upper Ballinderry, } \\
\text { Lisburn, Down } \\
\text { BT28 2PR }\end{array}$ & & $\begin{array}{l}\text { Ruins of a rath thought to be } \\
\text { the seat of the Kings of Ulster } \\
\text { are found on the south side of } \\
\text { the hill. The coronation stone } \\
\text { is found at the summit of the } \\
\text { hill. }\end{array}$ \\
\hline $\begin{array}{l}\text { Duneight Motte } \\
\text { and Bailey }\end{array}$ & $\begin{array}{l}\text { Lisburn, Antrim, } \\
\text { BT27 5LY }\end{array}$ & $12^{\text {th }}$ century & Norman fortification \\
\hline $\begin{array}{l}\text { Lisburn Castle } \\
\text { Gardens }\end{array}$ & $\begin{array}{l}\text { Castle Street, } \\
\text { Lisburn, Antrim } \\
\text { BT27 4SP }\end{array}$ & $17^{\text {th }}$ century & $\begin{array}{l}\text { Once the site of the Conway } \\
\text { familiy's fortified manor } \\
\text { house. The } 11^{\text {th }} \text { century } \\
\text { gardens and } 17^{\text {th }} \text { century } \\
\text { terraces have been restored. }\end{array}$ \\
\hline Lisburn Cathedral & $\begin{array}{l}\text { 24 Castle Street, } \\
\text { Lisburn, Antrim } \\
\text { BT27 4XD }\end{array}$ & $\begin{array}{l}\text { Early } 1600 \text { s - first } \\
\text { chapel } \\
1662-\text { second } \\
\text { church/cathedral } \\
\text { designation } \\
1708 \text { - third } \\
\text { cathedral }\end{array}$ & $\begin{array}{l}\text { First built as a chapel for the } \\
\text { Conway family, it was } \\
\text { destroyed in the Irish Rebellion } \\
\text { of } 1641 \text {. The chapel was } \\
\text { rebuilt and designated a } \\
\text { cathedral in } 1662 \text {. The second } \\
\text { building burned in a fire in } \\
\text { 1707. Groundbreaking for the } \\
\text { third and current cathedral } \\
\text { began in } 1708 \text {. In } 1914 \\
\text { protesting suffragettes bombed } \\
\text { the cathedral and destroyed the } \\
\text { oldest stained glass windows. }\end{array}$ \\
\hline Hilden Brewery & $\begin{array}{l}\text { Hilden House, } \\
\text { Grand Street, } \\
\text { Lisburn, Antrim } \\
\text { BT27 4TY }\end{array}$ & & $\begin{array}{l}\text { Microbrewery in a historic } \\
\text { house }\end{array}$ \\
\hline
\end{tabular}




\begin{tabular}{|c|c|c|c|}
\hline $\begin{array}{l}\text { Irish Linen Centre } \\
\& \text { Lisburn } \\
\text { Museum }\end{array}$ & $\begin{array}{l}\text { Market Square, } \\
\text { Lisburn, Antrim } \\
\text { BT27 1AG }\end{array}$ & $\begin{array}{l}17^{\text {th }} \text { century - } \\
\text { building is oldest } \\
\text { in Lisburn }\end{array}$ & $\begin{array}{l}\text { Exhibits on the Irish linen } \\
\text { industry, its importance to } \\
\text { Lisburn, and the city's history. } \\
\text { One exhibit "Lisburn 1912- } \\
1914 \text { examines the } \\
\text { ramifications of the Home } \\
\text { Rule debate in Lisburn and the } \\
\text { outbreak of WWI }\end{array}$ \\
\hline Downhill Beach & $\begin{array}{l}66 \text { Portstewart } \\
\text { Road, Coleraine, } \\
\text { Londonderry } \\
\text { BT52 1EY }\end{array}$ & & $\begin{array}{l}\text { A Game of Thrones site and } \\
\text { popular beach. }\end{array}$ \\
\hline $\begin{array}{l}\text { Murlough } \\
\text { National Nature } \\
\text { Reserve }\end{array}$ & $\begin{array}{l}\text { Dundrum, Down } \\
\text { BT33 0NQ }\end{array}$ & $\begin{array}{l}1967 \text { - gained } \\
\text { nature reserve } \\
\text { status }\end{array}$ & $\begin{array}{l}\text { Features a } 6000 \text { year old dune } \\
\text { system, Neolithic and Bronze } \\
\text { Age sites. Apart of the Mourne } \\
\text { Coastal Footpath. }\end{array}$ \\
\hline $\begin{array}{l}\text { The Mourne } \\
\text { Mountains }\end{array}$ & $\begin{array}{l}\text { Newry, Newry } \\
\text { and Mourne BT34 }\end{array}$ & & \\
\hline Murlough Bay & $\begin{array}{l}\text { Ballycastle, } \\
\text { Moyle, Antrim } \\
\text { BT54 6RG }\end{array}$ & & $\begin{array}{l}\text { Sightseeing site with views of } \\
\text { Rathlin Island and Scotland's } \\
\text { Mull of Kintyre. } \\
\text { A Game of Thrones site } \\
\text { Roger Casement's burial site of } \\
\text { choice (he's buried in Dublin). } \\
\text { Casement was an Irish } \\
\text { nationalist leader and was } \\
\text { executed by the British } \\
\text { government. A memorial is } \\
\text { annually held by Republican } \\
\text { Sinn Fein at the Bay }\end{array}$ \\
\hline Cushenden Caves & $\begin{array}{l}\text { Moyle, Antrim } \\
\text { BT44 }\end{array}$ & & $\begin{array}{l}\text { Owned by the National Trust } \\
\text { Formed over } 400 \text { million years } \\
\text { by extreme weather conditions } \\
\text { Views of Scotland's Mull of } \\
\text { Kintyre } \\
\text { A Game of Thrones site }\end{array}$ \\
\hline Larrybane Bay & $\begin{array}{l}\text { Ballintoy, } \\
\text { Ballycastle, } \\
\text { Antrim BT54 6LZ }\end{array}$ & & $\begin{array}{l}\text { Winds along the shore from } \\
\text { Carrick-A-Rede down to } \\
\text { Ballintoy Harbour. The site } \\
\text { offers natural attractions such } \\
\text { as the beach, caves and local } \\
\text { flora. } \\
\text { A Game of Thrones site }\end{array}$ \\
\hline $\begin{array}{l}\text { Carrick-A-Rede } \\
\text { Rope Bridge }\end{array}$ & $\begin{array}{l}\text { Ballycastle, } \\
\text { Antrim BT54 6LS }\end{array}$ & $1660 \mathrm{~s}$ & $\begin{array}{l}\text { A } 65 \mathrm{ft} \text { rope bridge suspended } \\
100 \mathrm{ft} \text { above sea level. The } \\
\text { bridge was built } 350 \text { years ago }\end{array}$ \\
\hline
\end{tabular}




\begin{tabular}{|c|c|c|c|}
\hline & & & $\begin{array}{l}\text { by fishermen and crosses to a } \\
\text { rocky island }\end{array}$ \\
\hline Ballintoy Harbour & $\begin{array}{l}\text { Ballintoy, } \\
\text { Ballycastle, } \\
\text { Antrim BT54 } \\
\text { 6NA }\end{array}$ & & $\begin{array}{l}\text { An example of rural Northern } \\
\text { Ireland and a fishing } \\
\text { community. Attractinos } \\
\text { include: Bendhu House, } \\
\text { Dunseverick Castle, Carrick- } \\
\text { A-Rede Rope Bridge, Sheep } \\
\text { Island and the local parish } \\
\text { church. } \\
\text { A Game of Thrones site }\end{array}$ \\
\hline $\begin{array}{l}\text { Dunseverick } \\
\text { Castle }\end{array}$ & & $\begin{array}{l}\text { Built before } \\
500 \mathrm{CE}\end{array}$ & $\begin{array}{l}\text { In the } 5^{\text {th }} \text { century the castle was } \\
\text { visited by St Patrick. In the } 6^{\text {th }} \\
\text { century it was the seat of } \\
\text { Fergus Mor MacEirc (Fergus } \\
\text { the Great), King of Dalriada } \\
\text { and uncle to Muirceartaigh } \\
\text { MacEirc, High King of Ireland. } \\
\text { Became home of the O'Cahan } \\
\text { family from } 1000-1320 \text {. } \\
1642 \text { Robert Munro and his } \\
\text { troops destroy the castle in the } \\
\text { Irish Rebellion of } 1641 \text {. Only } \\
\text { the gatelodge remains. } \\
\text { Part of the Causeway Coastal } \\
\text { Trail }\end{array}$ \\
\hline $\begin{array}{l}\text { Castle Ward } \\
\text { Estate }\end{array}$ & $\begin{array}{l}\text { Park Road, } \\
\text { Downpatrick, } \\
\text { Down BT30 7LS }\end{array}$ & $\begin{array}{l}1590-\text { Old Castle } \\
\text { Ward } \\
1720-1850 \text { Judge } \\
\text { Ward house } \\
\text { (demolished; } \\
\text { landscaping } \\
\text { remains) } \\
1760 \text { s - current } \\
\text { Ward Castle }\end{array}$ & $\begin{array}{l}\text { Home of the Ward family since } \\
1570 \\
850 \text { acre estate } \\
\text { The current house was built in } \\
\text { two styles Palladian and } \\
\text { Georgian Gothic. } \\
\text { In } 1973 \text { PIRA members } \\
\text { Leonard O'Hanlon and } \\
\text { Vivienne Fitzsimmons were } \\
\text { killed in a premature bomb } \\
\text { blast. }\end{array}$ \\
\hline Audley's Castle & $\begin{array}{l}\text { Audleystown } \\
\text { Road, } \\
\text { Portloughan, } \\
\text { Downpatrick, } \\
\text { Down BT30 7LP }\end{array}$ & $15^{\text {th }}$ century & $\begin{array}{l}\text { Audley's Castle is a three story } \\
\text { Tower house - one of the most } \\
\text { common archaeological } \\
\text { features in Ireland. They are } \\
\text { features from the late Middle } \\
\text { Ages. } \\
\text { Part of the Ward Estate } \\
\text { A Game of Throne site }\end{array}$ \\
\hline
\end{tabular}




\begin{tabular}{|l|l|l|l|}
\hline Down Cathedral & $\begin{array}{l}\text { English Street, } \\
\text { Downpatrick, } \\
\text { Down BT30 6AB }\end{array}$ & $12^{\text {th }}$ century & $\begin{array}{l}\text { Supposed burial site of St } \\
\text { Patrick, St Brigid and St } \\
\text { Colomban. } \\
\text { A Christian heritage site. }\end{array}$ \\
\hline
\end{tabular}




\section{APPENDIX B}

\section{HERITAGE SITE MAP}

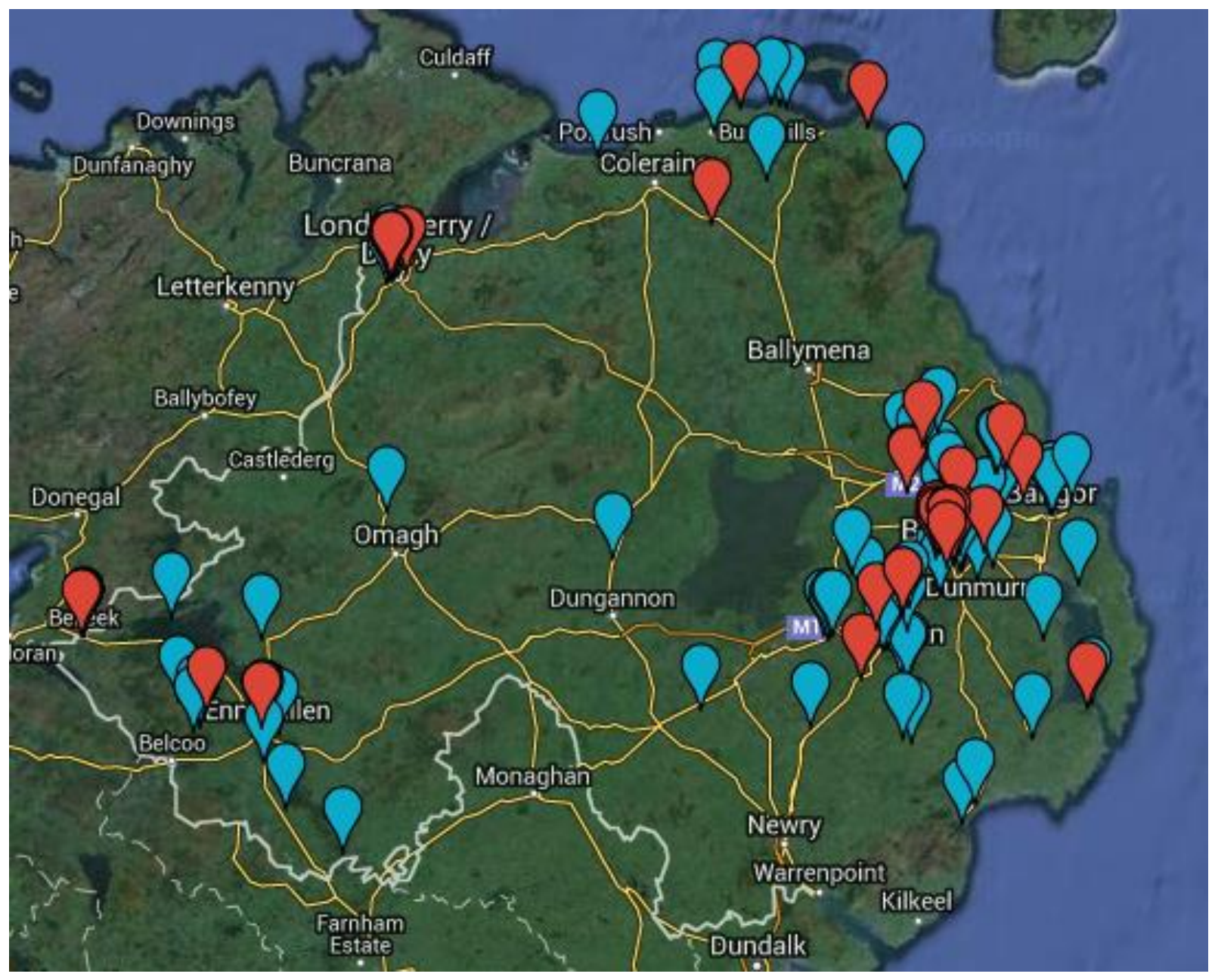

Figure 4: Northern Ireland Heritage Sites. Blue pins represent regular heritage sites while red pins are conflict sites 


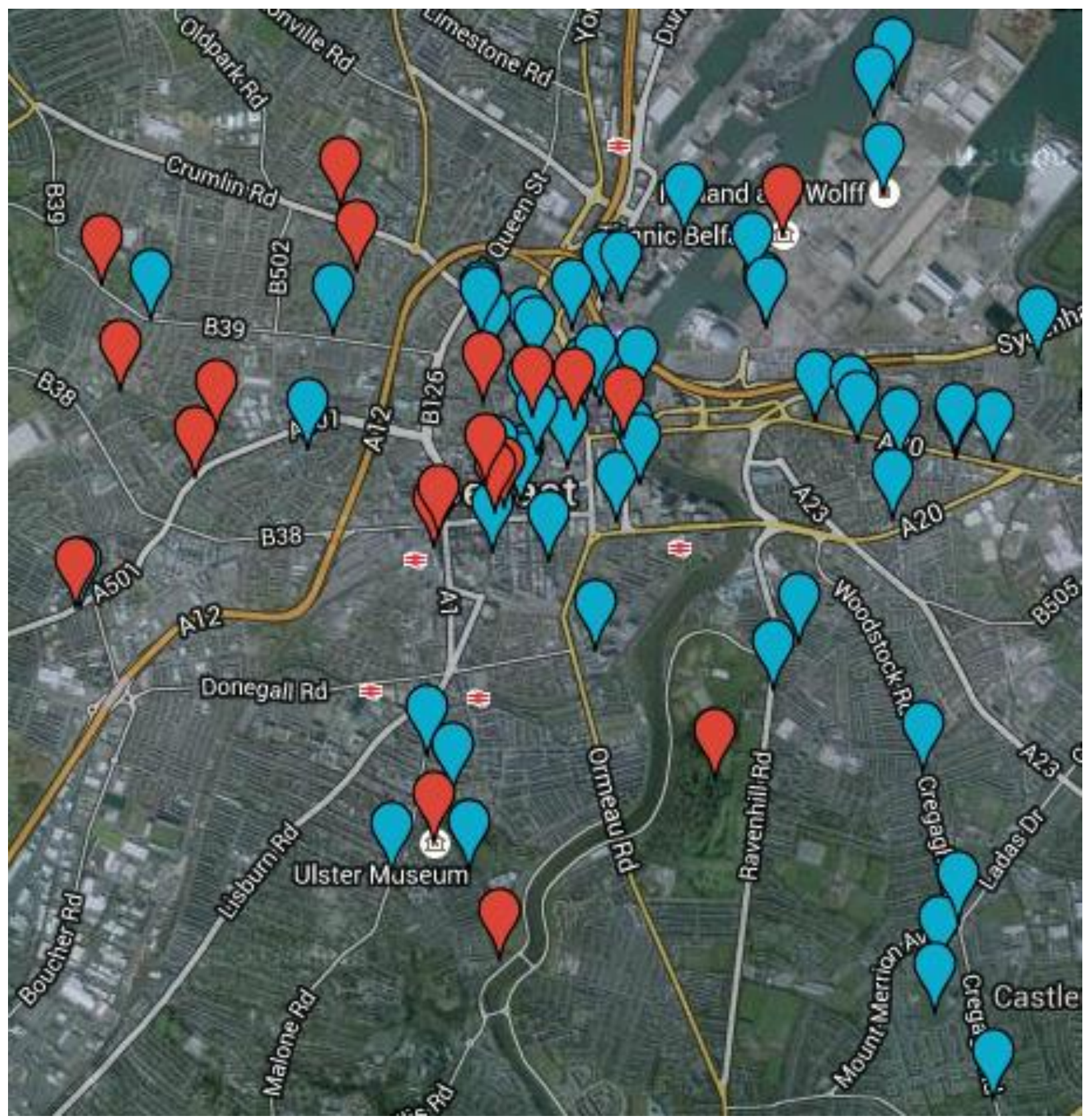

Figure 5: Close-up of Belfast heritage site distribution 


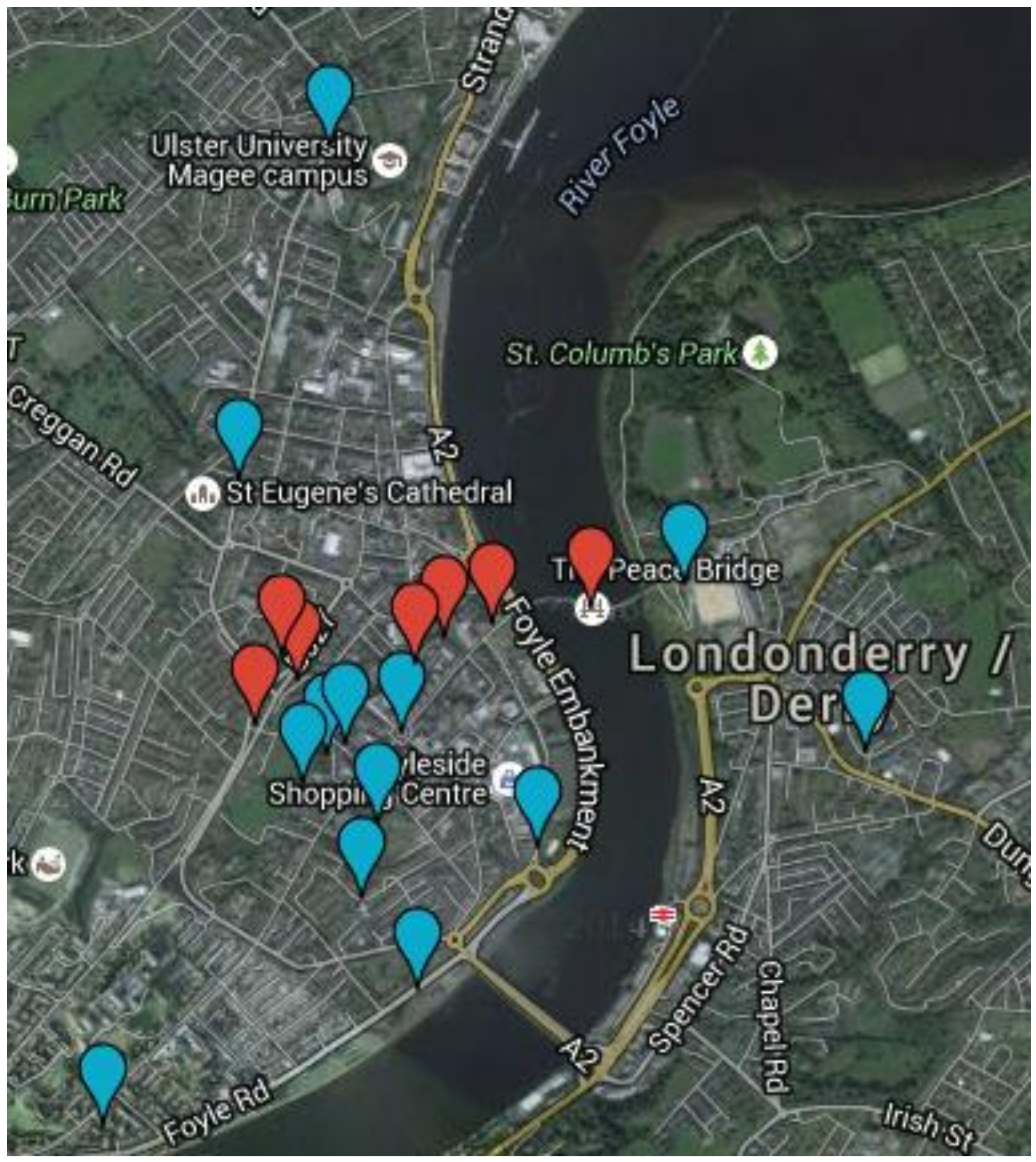

Figure 6: Close-up of Derry/Londonderry heritage site distribution.

Link to Interactive Map 


\section{APPENDIX C}

\section{MAPS}

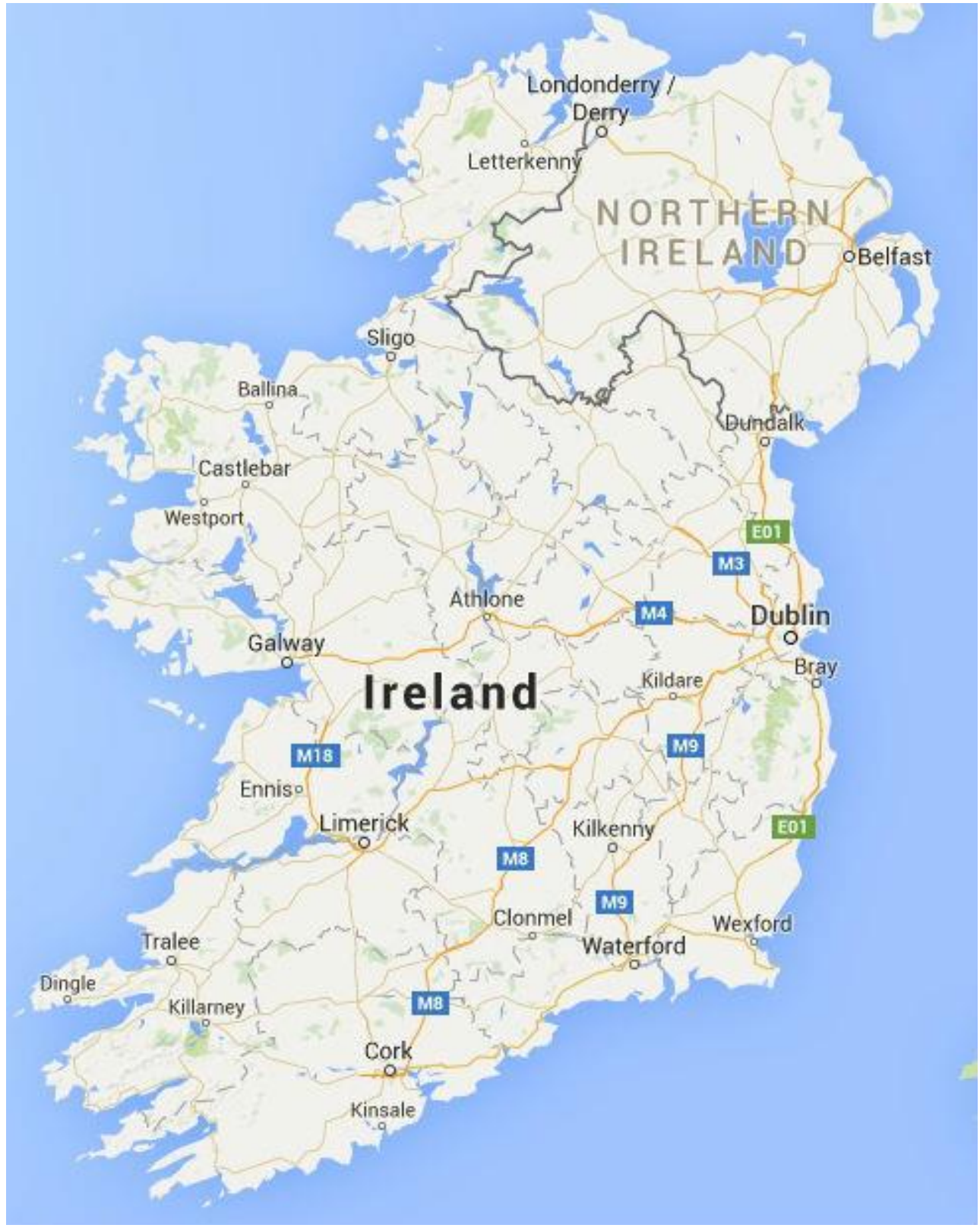

Figure 7: Map of Ireland. Source: Google Maps 


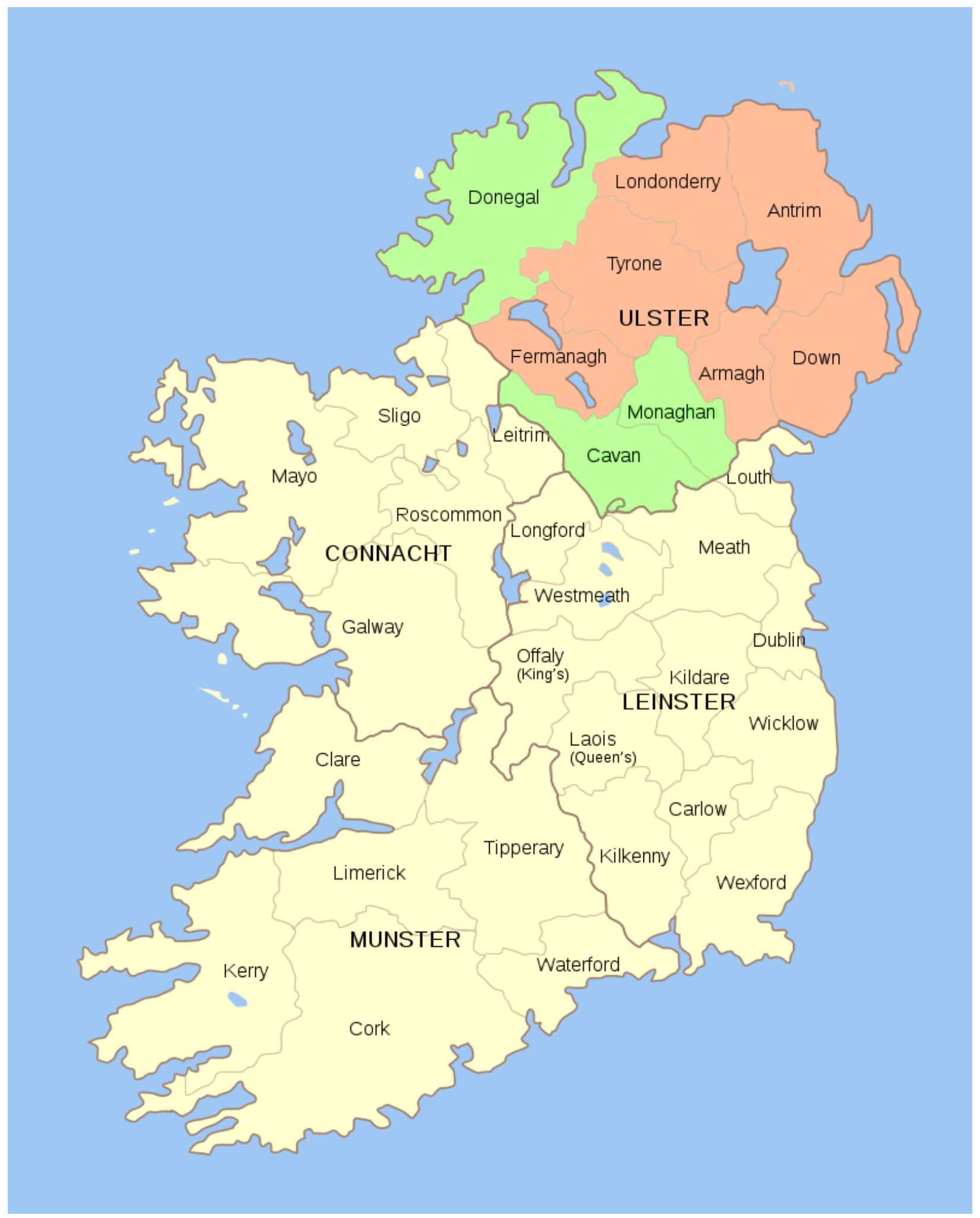

Figure 8: Region map of Ireland showing division of Ulster. Source: Future Perfect at Sunrise https://en.wikipedia.org/wiki/Ulster\#/media/File:Ulster_counties.svg 


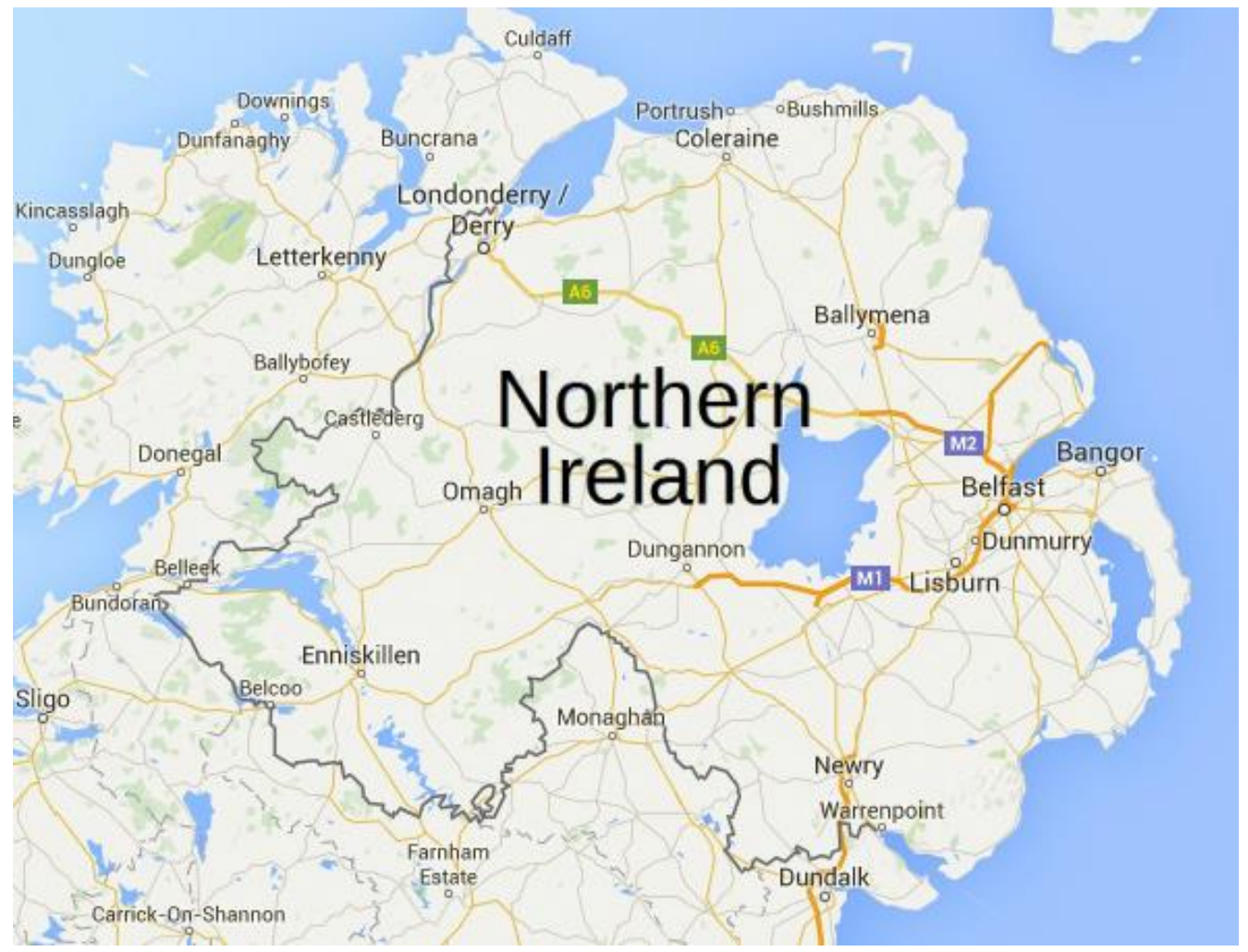

Figure 9: Map of Northern Ireland. Source: Google Maps

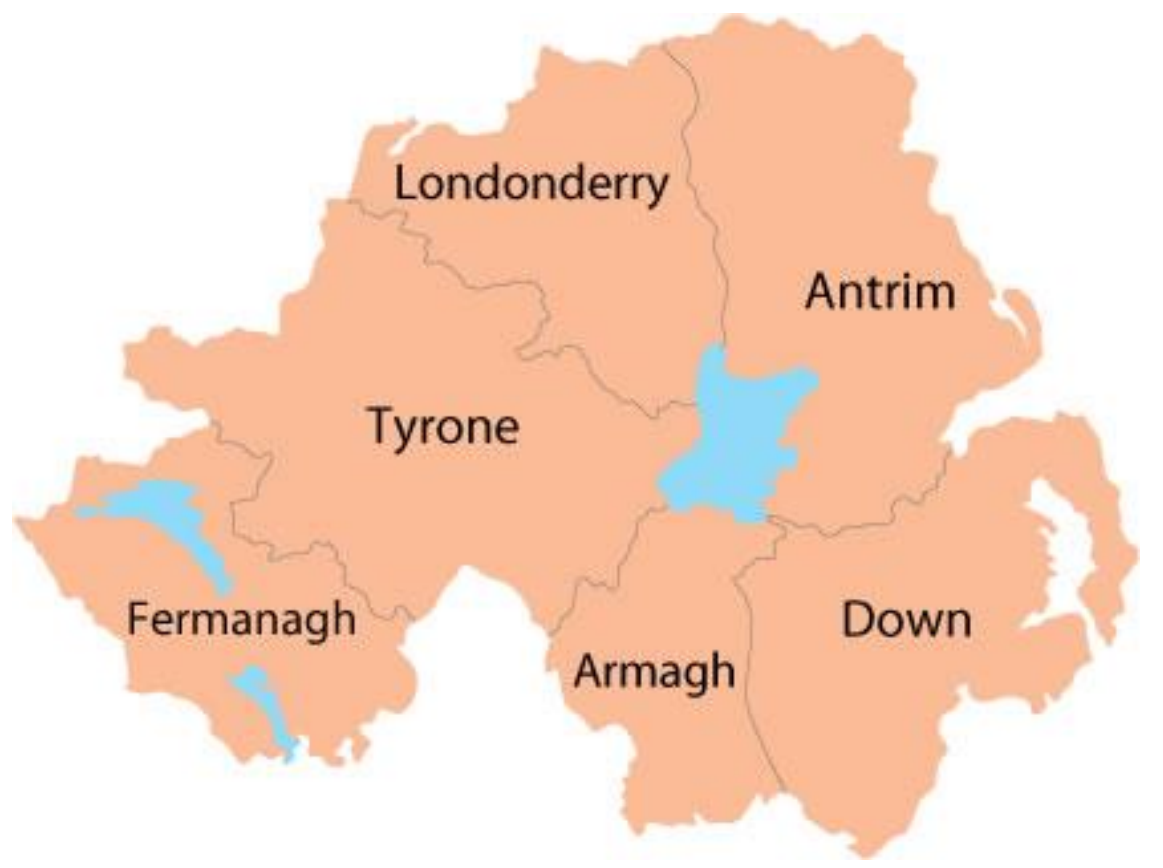

Figure 10: County map of Northern Ireland Source: Landscape Institute Northern Ireland http://www.landscapeinstitute.org/northernireland/about/map.php 


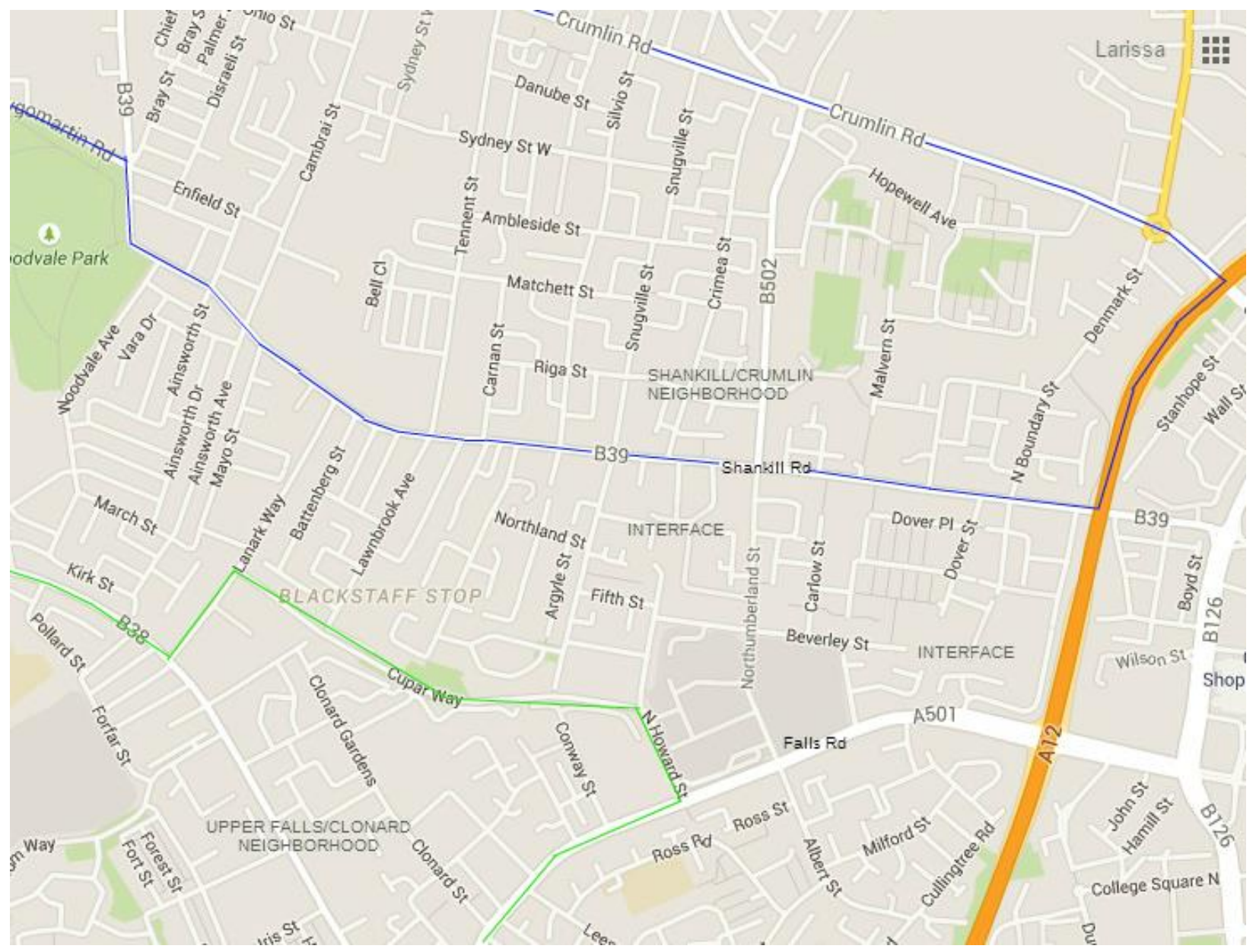

Figure 11: Falls-Shankill Interface. Source: Google Maps for base map 


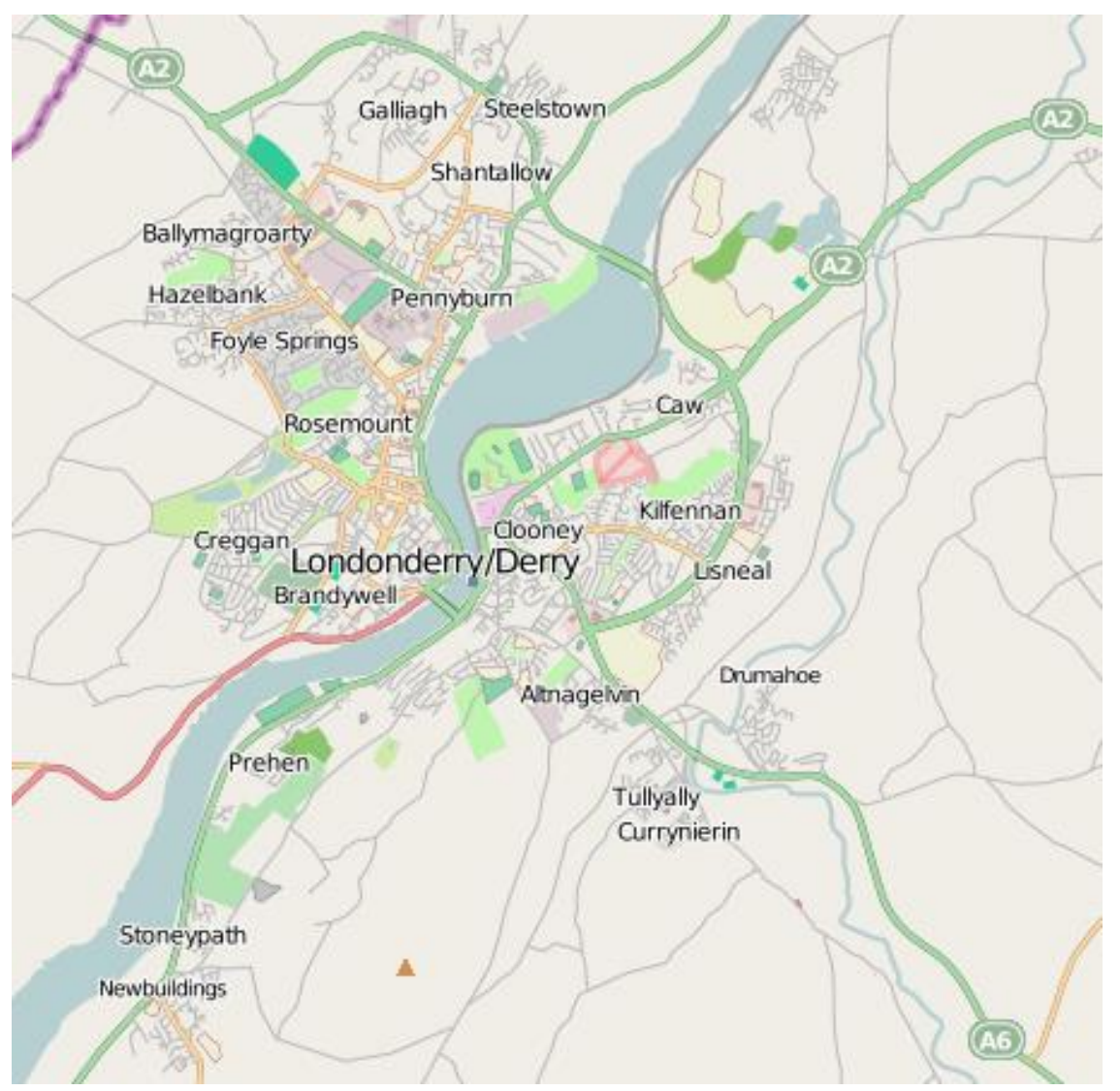

Figure 12: Map of Derry/Londonderry. Source: Open Street Map

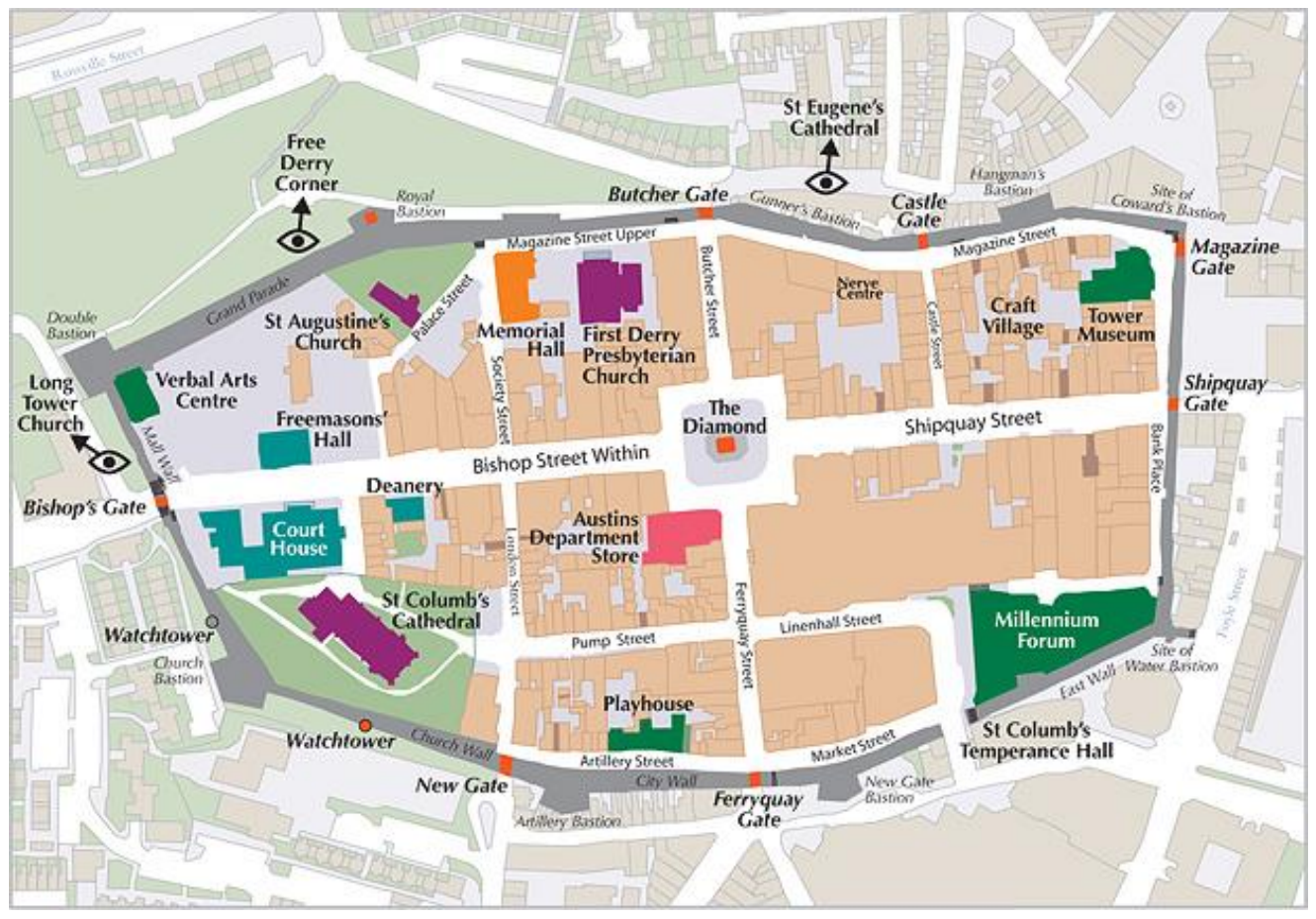

Figure 13: Detail of Walled City in Derry/Londonderry. Source: Derry City Council 


\section{APPENDIX D}

\section{ABBREVIATIONS}

$\begin{array}{ll}\text { DCAL } & \text { Department of Culture, Arts and Leisure } \\
\text { DEL } & \text { Department of Employment and Learning } \\
\text { DETI } & \text { Department of Enterprise, Trade and Investment } \\
\text { DRD } & \text { Department for Regional Development } \\
\text { DUP } & \text { Democratic Unionist Party } \\
\text { IRA } & \text { Irish Republican Army } \\
\text { NIAO } & \text { Northern Ireland Audit Office } \\
\text { NICRA } & \text { Northern Ireland Civil Rights Association } \\
\text { NITB } & \text { Northern Ireland Tourist Board } \\
\text { NITIC } & \text { Northern Ireland Tourist Industry Confederation } \\
\text { OIRA } & \text { Official IRA } \\
\text { PIRA } & \text { Provisional IRA } \\
\text { PSNI } & \text { Police Service Northern Ireland } \\
\text { RAC } & \text { Relatives Action Committee } \\
\text { RIRA } & \text { Real IRA } \\
\text { RoI } & \text { Republic of Ireland } \\
\text { RPT } & \text { Regional Tourism Partnerships } \\
\text { RUC } & \text { Royal Ulster Constabulary } \\
\text { SDLP } & \text { Social Democratic and Labour Party } \\
\text { TTT } & \text { Tourism Training Trust } \\
\text { UDA } & \text { Ulster Defence Association } \\
\text { UK } & \text { United Kingdom } \\
& \end{array}$


UNWTO United Nations World Tourism Organization

UTDA Ulster Tourist Development Association

UUP Ulster Unionist Party

UVF Ulster Volunteer Force 


\section{CURRICULUM VITAE}

NAME: $\quad$ Ashleigh Larissa Bixby

ADDRESS: 942 Ellison Ave

Louisville, KY 40204

DOB: $\quad$ Louisville, Kentucky - 23 September 1987

EDUCATION

\& TRAINING: $\quad$ B.A., Anthropology

University of Tennessee

2006-2010

M.A., Anthropology

University of Louisville

2010-2015

AWARDS: Golden Key Honour Society Member

2011 